\title{
WestVirginiaUniversity
}

THE RESEARCH REPOSITORY @ WVU

Graduate Theses, Dissertations, and Problem Reports

2014

\section{Energy Intensity Determination in Wood Processing Sawmills}

\author{
Ramakrishna Babu Maddula \\ West Virginia University
}

Follow this and additional works at: https://researchrepository.wvu.edu/etd

\section{Recommended Citation}

Maddula, Ramakrishna Babu, "Energy Intensity Determination in Wood Processing Sawmills" (2014).

Graduate Theses, Dissertations, and Problem Reports. 611.

https://researchrepository.wvu.edu/etd/611

This Thesis is protected by copyright and/or related rights. It has been brought to you by the The Research Repository @ WVU with permission from the rights-holder(s). You are free to use this Thesis in any way that is permitted by the copyright and related rights legislation that applies to your use. For other uses you must obtain permission from the rights-holder(s) directly, unless additional rights are indicated by a Creative Commons license in the record and/ or on the work itself. This Thesis has been accepted for inclusion in WVU Graduate Theses, Dissertations, and Problem Reports collection by an authorized administrator of The Research Repository @ WVU. For more information, please contact researchrepository@mail.wvu.edu. 


\title{
Energy Intensity Determination in Wood Processing Sawmills
}

\author{
Ramakrishna Babu Maddula
}

\author{
Thesis submitted \\ to the Benjamin M. Statler College of Engineering and Mineral Resources \\ at West Virginia University \\ in partial fulfillment of the requirements for the degree of \\ Master of Science in \\ Industrial Engineering
}

Bhaskaran Gopalakrishnan, Ph.D., P.E., Chair

Robert C. Creese, Ph.D., P.E.

Shawn T. Grushecky, Ph.D. (Div. of Forestry \& Nat. Resources)

Department of Industrial and Management Systems Engineering

Morgantown, West Virginia

2014
Keywords: Sawmill, Energy Efficiency, Electrical Data Logging, Specific Energy Consumption, Lumber Production

Copyright 2014 [Ramakrishna Babu Maddula] 


\section{Abstract \\ Energy Intensity Determination in Wood Processing Sawmills}

\section{Ramakrishna Babu Maddula}

Energy intensity is an important aspect to wood products producing sawmills in the State of West Virginia. This research aims to facilitate the accurate measurement of electrical energy intensity in sawmills by means of energy analysis and diagnostics using various data acquisition devices on electrical motors used in the manufacturing processes. Close to $90 \%$ of the electrical energy used in a typical sawmill is consumed by motors alone. The energy intensity determination is being accomplished by data collection with respect to electrical energy consumption parameters as well as production parameters. The electrical energy consumption was recorded on all the major motors in three sawmills for a period of one month. The recorded data were analyzed with respect to the production volume and the specific energy consumption for different size lumber of varying species was developed. The specific energy allocation for different size lumber was done based on the surface area cut to manufacture that lumber. The specific energy consumption of a particular size lumber has been compared with respect to different species. The specific energy consumption of different size lumber of the same species was developed. Sawmills can evaluate the impact of their production decisions on energy consumption using the results of this research. Energy consumption of different size and species was compared among three sawmills. Specific energy consumption of hardwood species in sawmill 1 for $4 / 4$ lumber is varying from $124 \mathrm{kwh}$ to 170 $\mathrm{kWh}$ per 1,000 board feet, where as in sawmill 2 it is varying from $79 \mathrm{kwh}$ to $118 \mathrm{kWh}$ and in sawmill 3 it is varying from $90 \mathrm{kwh}$ to $145 \mathrm{kWh}$. Further, results of the energy assessment conducted in each sawmill would save on average $12 \%$ of energy consumption at current operation. Finally, productivity improvement that can be achieved by sawing high quality logs and using new saw blade technologies were discussed. 


\section{Dedication}

This thesis work dedicated to my parents, Janaki and Ravi Maddula and grandparents, Mohana and Suryanarayana Maddula, for their love, endless support, and encouragement. This work is also

dedicated to my friend, Dayakar Devaru, who has been a constant source of support and encouragement during the challenges of graduate school and life. 


\section{Acknowledgement}

I would like to wholeheartedly thank my advisor, Dr. B. Gopalakrishnan, for his continued support, guidance, and encouragement during my entire course of graduate studies at WVU and during the conduct of this research work. I also wish to thank my research committee members, Dr. Robert Creese and Dr. Shawn Grushecky for their constant advice and support and for providing me a scientific perspective to the analytical approach used in this research. I would like to extend my special thanks to Mr. Bill Glasscock, Mr. Ed Dallison, Mr. John DiLorenzo, and Mr. Tyler King, and the staff at sawmill facilities who made it possible to collect the invaluable data required for this research. I wish to extend my special thanks to Mr. Dayakar Devaru and Mr. Subodh Chaudhari for their invaluable help and support for the success of this project.

Above all, I wish to thank God, my loving parents, and all my friends for their constant support and blessings and enabling my success and happiness in all my pursuits and endeavors in life. 


\section{Table of Contents}

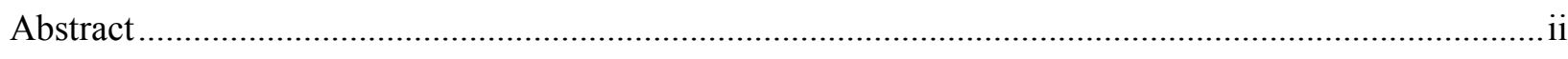

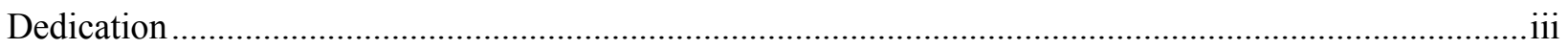

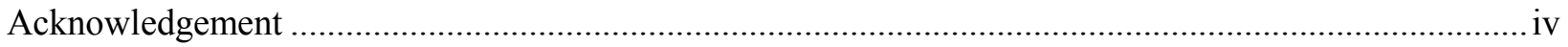

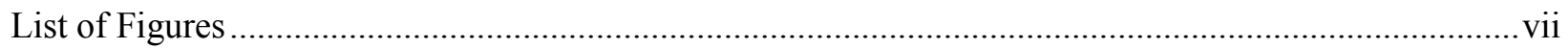

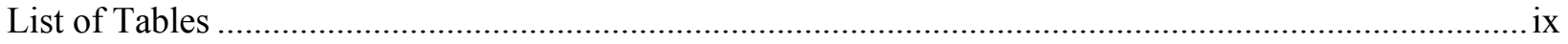

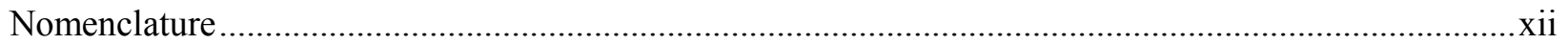

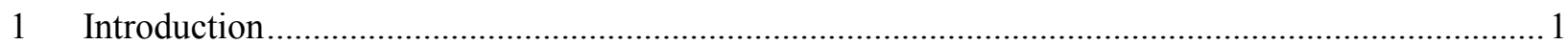

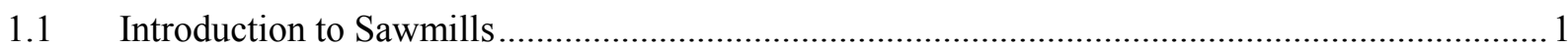

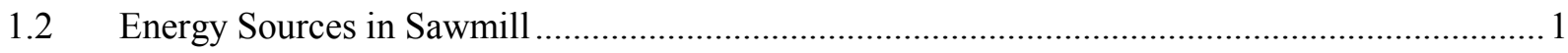

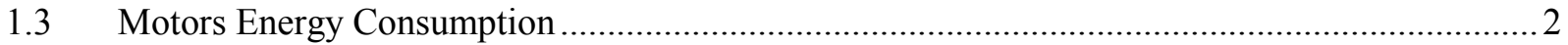

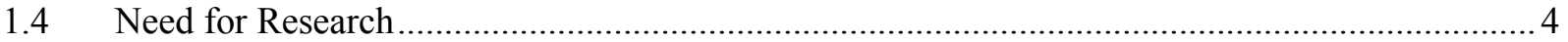

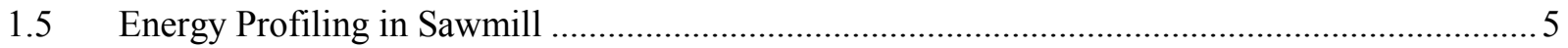

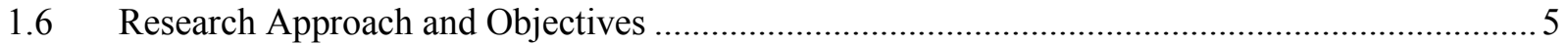

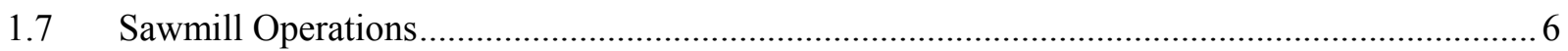

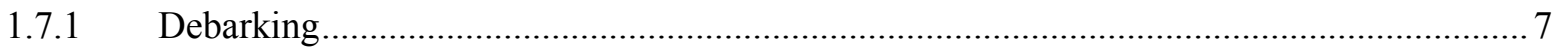

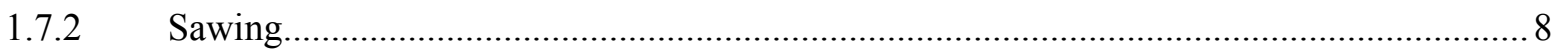

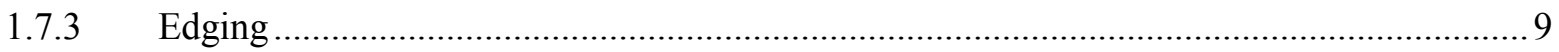

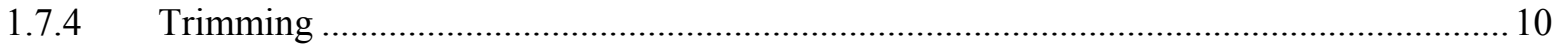

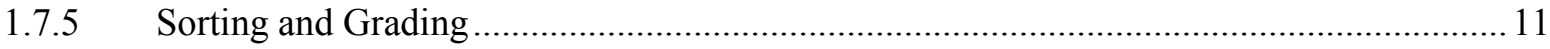

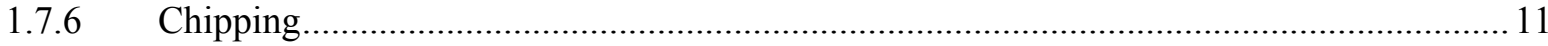

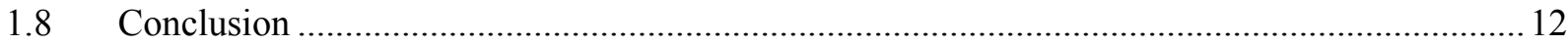

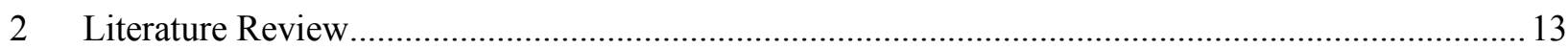

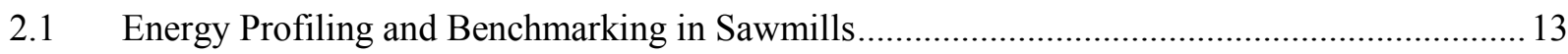

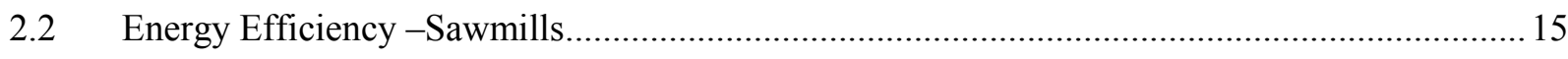

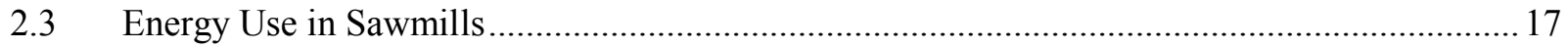

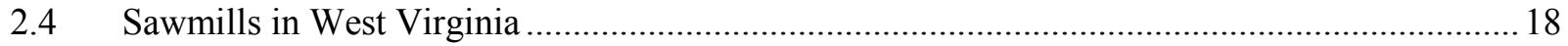

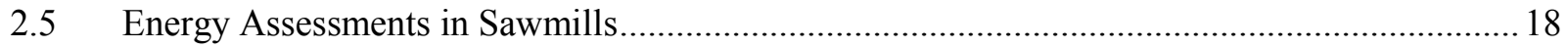

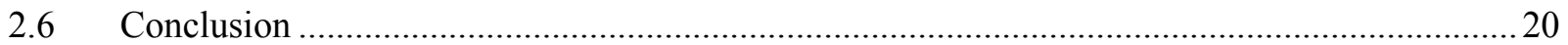

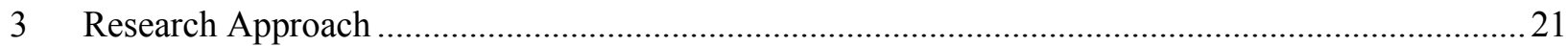

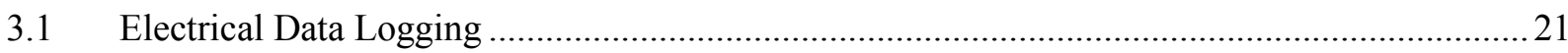

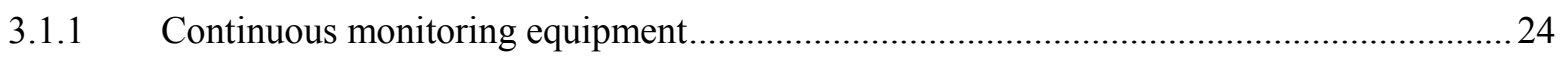

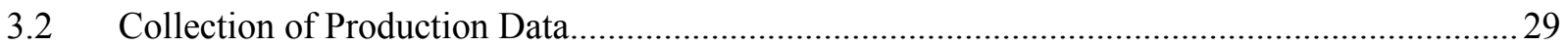




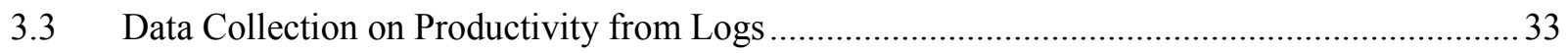

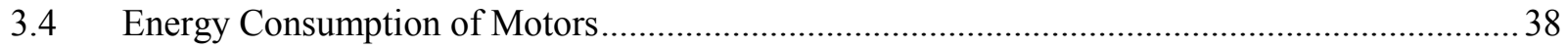

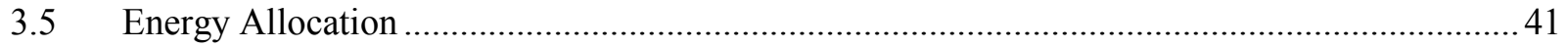

3.5.1 Sensitivity analysis for Energy consumption of Main saw, Re-saw, and Gang saw for

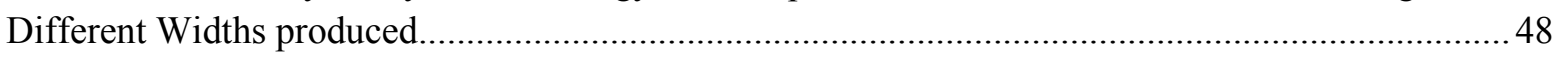

3.6 Data Collection of Saw Material and Maintenance ................................................................ 49

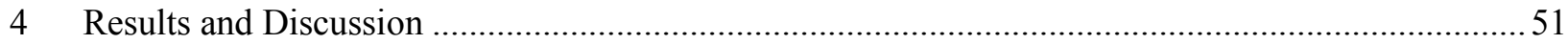

4.1 Average Energy Consumption in Data Logged Sawmills vs Case Studies ..............................51

4.2 Energy Consumption and Lumber Production in Sawmills...................................................52

$4.3 \quad$ Energy consumption of different species for different sizes ...............................................55

4.4 Energy Consumption of Different Species Lumber of Same Size ........................................... 72

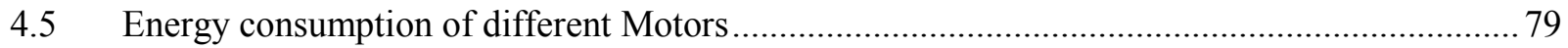

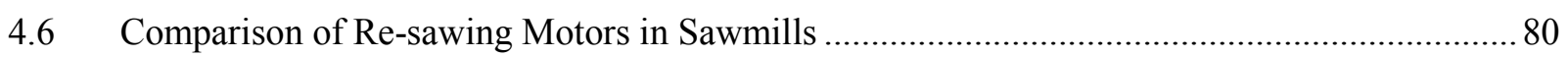

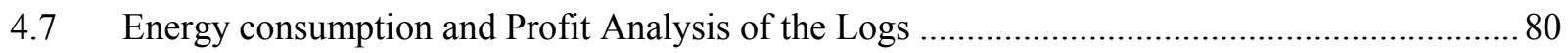

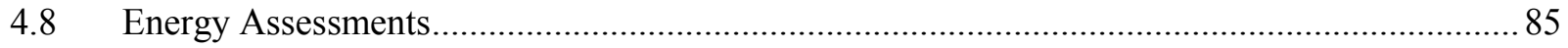

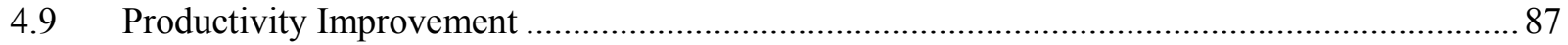

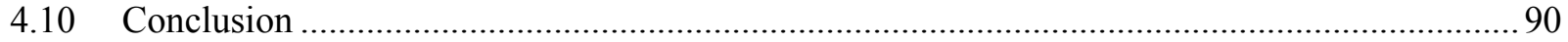

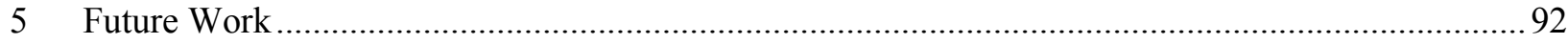

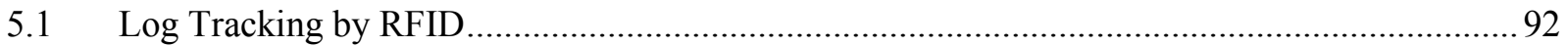

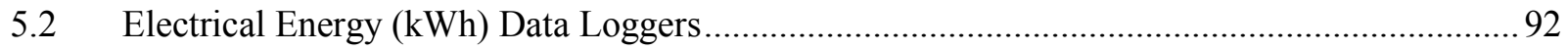

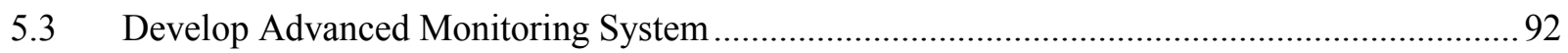

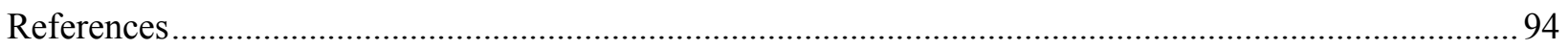

Appendix 


\section{List of Figures}

Figure 1.3.2: Electricity Usage in a Sawmill ................................................................................. 2

Figure 1.3.3: Electricity Usage of Motors in a Sawmill ........................................................................ 3

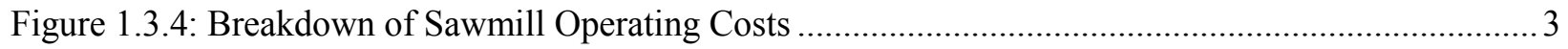

Figure 1.7.1: Process Flow for Sawmill Operations-Green Lumber..................................................... 7

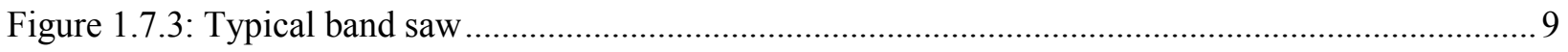

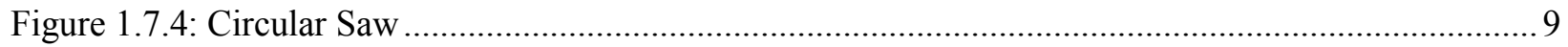

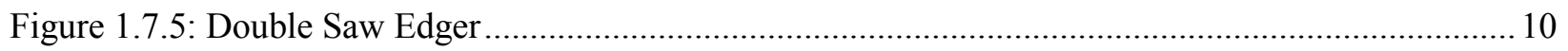

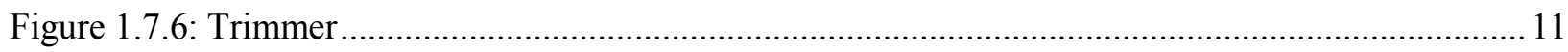

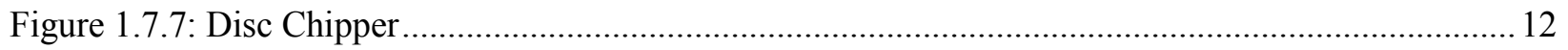

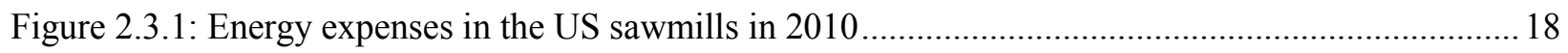

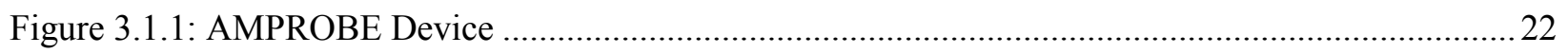

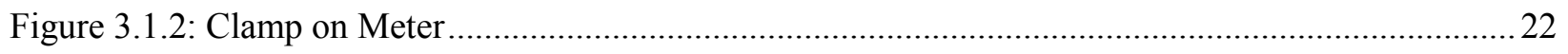

Figure 3.1.3: A Snapshot of Download Suite Software .........................................................................23

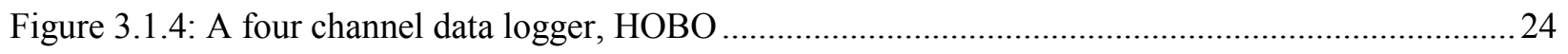

Figure 3.1.5: Current Transducers for 600 Amps and 200 Amps ......................................................2

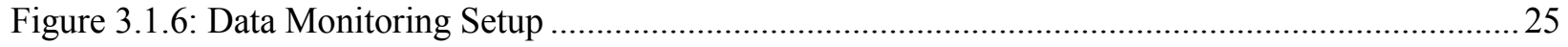

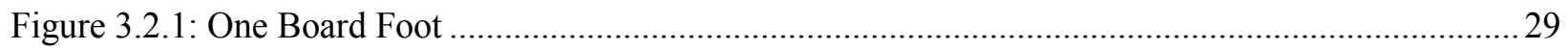

Figure 3.5.1: Surface Area Cut by Main Saw, Edger, and Trimmer...................................................... 45

Figure 3.5.2: Sensitivity Analysis of Re-saw for Different Widths- Red Oak........................................ 49

Figure 4.2.1: Energy Consumption vs Lumber Production in Sawmill 1 ................................................52

Figure 4.2.2: Energy Consumption vs Lumber Production in Sawmill 2 ...............................................53

Figure 4.2.3: Energy Consumption vs Lumber Production in Sawmill 3 ...............................................5

Figure 4.3.1: Energy Profile of 4/4 Size Lumber with Different Widths - Hickory .................................56

Figure 4.3.2: Energy Profile of 4/4 Size Lumber with Different Widths - Hard Maple ............................58

Figure 4.3.3: Energy Profile of 4/4 Size Lumber with Different Widths-Red Oak ................................... 61

Figure 4.3.4: Energy Profile of 8/4 Size Lumber with Different Widths - Red Oak ................................61

Figure 4.3.5: Energy Profile of 5/4 Size Lumber with Different Widths - Red Oak ................................ 62

Figure 4.3.6: Energy Profile of 4/4 Size Lumber with Different Widths - White Oak .............................. 64

Figure 4.3.7: Energy Profile of 5/4 Size Lumber with Different Widths - White Oak .............................6 65

Figure 4.3.8: Energy Profile of 6/4 Size Lumber with Different Widths - White Oak..............................65 
Figure 4.3.11: Energy Profile of 4/4 Size Lumber with Different Widths - Ash ...................................... 69

Figure 4.3.12: Energy Profile of 4/4 Size Lumber with Different Widths - Cherry …............................. 72

Figure 4.4.1: Energy Profile of Various Species - 4/4 Size and 6" Width .............................................. 73

Figure 4.4.2: Energy Profile of Various Species - 5/4 Size and 6" Width ...............................................74

Figure 4.4.3: Energy Profile of Various Species - 6/4 Size and 6" Width ................................................. 75

Figure 4.4.4: Energy Profile of Various Species - 8/4 Size and 6" Width ............................................... 75

Figure 4.4.5: Energy Profile of Cants with 3" Thick and 6" Width........................................................... 76

Figure 4.4.6: Energy Profile of Cants with 3.5” Thick and 6" Width..................................................... 77

Figure 4.4.7: Energy Profile of Ties for Different Species ……........................................................... 78

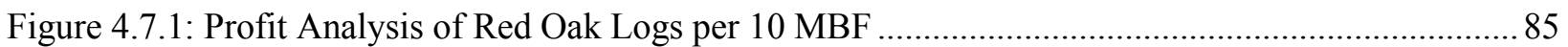




\section{List of Tables}

Table 2.1.1: Energy Consumption to produce $1 \mathrm{MBF}$ of Lumber from Different Studies ........................ 15

Table 2.5.1: Energy Savings in Sawmills from Energy Assessments discussed in Different Studies ........20

Table 3.1.1: Electrical Parameters of motors in Sawmills ....................................................................28

Table 3.1.2: Energy Consumption from the Data Loggers vs Electricity Bills .......................................29

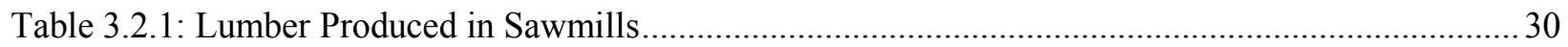

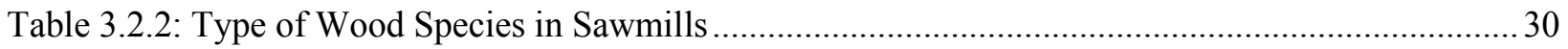

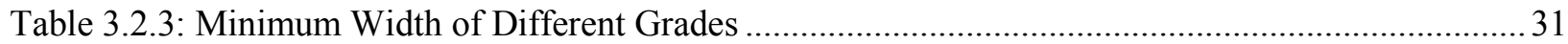

Table 3.2.4: Breakdown of Lumber Production as per Grades in Sawmills ............................................. 32

Table 3.2.5: Breakdown of Lumber Production as per Thickness in Sawmills ....................................... 32

Table 3.2.5: Sizes of Pallets, Cants, and Timbers in Each Sawmill ...................................................... 32

Table 3.3.1: Lumber Produced from Different Grade Logs.................................................................... 34

Table 3.3.2: Percentages of Lumber Produced from Different Grade Logs ............................................ 36

Table 3.3.3: Average Percentages of Lumber Produced from Different Grade Logs.............................. 37

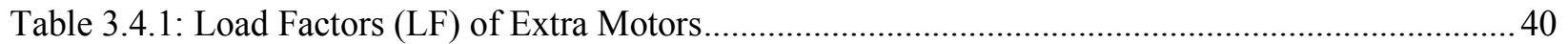

Table 3.5.1: Lumber Production and Energy Consumption during Each Shift in Sawmill 1 ...................41

Table 3.5.2: Lumber Production and Energy Consumption during Each Shift in Sawmill 2 .................. 43

Table 3.5.3: Lumber Production and Energy Consumption during Each Shift in Sawmill 3 ................... 44

Table 3.5.4: Re-saw Electricity Consumption for Different Widths- Red Oak ...................................... 48

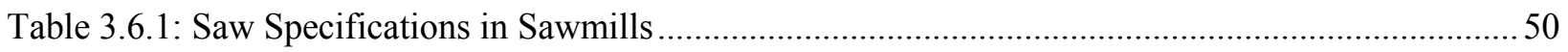

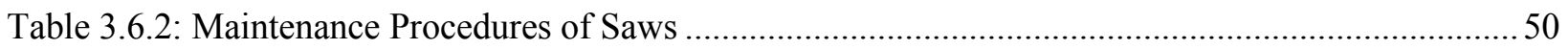

Table 4.1.1: Average Energy Consumption vs Previous Studies...........................................................5

Table 4.1.2: Percentage of Lumber Produced in Each sawmill ..............................................................51

Table 4.3.1: Total Energy Consumption of Different Sizes in Sawmill 1-Hickory ..................................55

Table 4.3.2: Specific Energy Consumption of Different Sizes in Sawmill 1-Hickory ..............................55

Table 4.3.3: Total Energy Consumption of Different Sizes in Sawmill 2-Hickory .................................56

Table 4.3.4: Specific Energy Consumption of Different Sizes in Sawmill 2-Hickory ..............................56

Table 4.3.5: Total Energy Consumption of Different Sizes in Sawmill 1-Hard Maple...........................57

Table 4.3.6: Specific Energy Consumption of Different Sizes in Sawmill 1-Hard Maple ........................57

Table 4.3.7: Total Energy Consumption of Different Sizes in Sawmill 2-Hard Maple............................57

Table 4.3.8: Specific Energy Consumption of Different Sizes in Sawmill 2-Hard Maple .........................57 
Table 4.3.9: Total Energy Consumption of Different Sizes in Sawmill 3-Hard Maple. .58

Table 4.3.10: Specific Energy Consumption of Different Sizes in Sawmill 3-Hard Maple .......................58

Table 4.3.11: Total Energy Consumption of Different Sizes in Sawmill 1-Red Oak...............................59

Table 4.3.12: Specific Energy Consumption of Different Sizes in Sawmill 1-Red Oak ...........................59

Table 4.3.13: Total Energy Consumption of Different Sizes in Sawmill 2-Red Oak...............................59

Table 4.3.14: Specific Energy Consumption of Different Sizes in Sawmill 2-Red Oak ..........................60

Table 4.3.15: Total Energy Consumption of Different Sizes in Sawmill 3-Red Oak............................... 60

Table 4.3.16: Specific Energy Consumption of Different Sizes in Sawmill 3-Red Oak ........................... 60

Table 4.3.17: Total Energy Consumption of Different Sizes in Sawmill 1-White Oak...........................62

Table 4.3.18: Specific Energy Consumption of Different Sizes in Sawmill 1-White Oak........................63

Table 4.3.19: Total Energy Consumption of Different Sizes in Sawmill 2-White Oak............................63

Table 4.3.20: Specific Energy Consumption of Different Sizes in Sawmill 2-White Oak........................63

Table 4.3.21: Total Energy Consumption of Different Sizes in Sawmill 3-White Oak............................ 64

Table 4.3.22: Specific Energy Consumption of Different Sizes in Sawmill 3-White Oak........................64

Table 4.3.23: Total Energy Consumption of Different Sizes in Sawmill 1-Poplar ................................... 66

Table 4.3.24: Specific Energy Consumption of Different Sizes in Sawmill 1-Poplar............................... 66

Table 4.3.25: Total Energy Consumption of Different Sizes in Sawmill 3-Poplar .................................. 66

Table 4.3.26: Specific Energy Consumption of Different Sizes in Sawmill 3-Poplar............................... 67

Table 4.3.27: Total Energy Consumption of Different Sizes in Sawmill 2-Ash .................................... 68

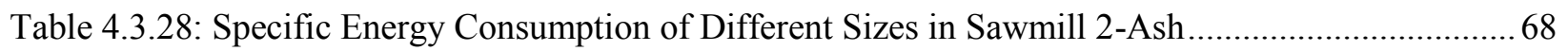

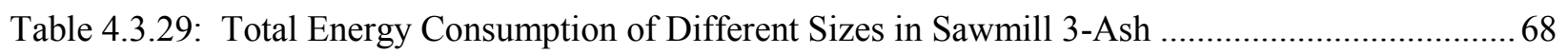

Table 4.3.30: Specific Energy Consumption of Different Sizes in Sawmill 3-Ash..................................68

Table 4.3.30: Total Energy Consumption of Different Sizes in Sawmill 2-Soft Maple ..........................69

Table 4.3.31: Specific Energy Consumption of Different Sizes in Sawmill 2-Soft Maple ........................ 70

Table 4.3.32: Total Energy Consumption of Different Sizes in Sawmill 3-Soft Maple ........................... 70

Table 4.3.33: Specific Energy Consumption of Different Sizes in Sawmill 3-Soft Maple .......................70

Table 4.3.34: Total Energy Consumption of Different Sizes in Sawmill 2-Cherry .................................. 71

Table 4.3.35: Specific Energy Consumption of Different Sizes in Sawmill 2-Cherry ….......................... 71

Table 4.4.1: Specific Energy Consumption of 4/4 Size Lumber of Different Species ............................. 73

Table 4.4.2: Specific Energy Consumption of 5/4 size lumber of Different Species .............................. 74

Table 4.4.3: Specific Energy Consumption of 6/4 size lumber of Different Species ............................. 74 
Table 4.4.4: Specific Energy Consumption of 8/4 size lumber of Different Species ..............................75

Table 4.4.5: Specific Energy Consumption of cants with 3" thickness of Different Species ................... 76

Table 4.4.6: Specific Energy Consumption of cants with 3.5" thickness of Different Species ................. 77

Table 4.4.7: Specific Energy Consumption of Ties of Different Species ................................................... 78

Table 4.5.1: Energy Consumption of Sawing Motors for the Production of Lumber............................... 79

Table 4.5.2: Energy Consumption of Chipper for the Production of Lumber ........................................ 79

Table 4.7.1: Prices of Different Grade Logs Obtained from Sawmill 3 ................................................ 81

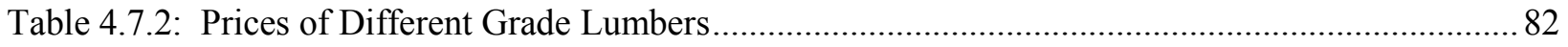

Table 4.7.3: Cost and Profit Analysis for Sawing 10 MBF of Red Oak Logs ........................................ 84

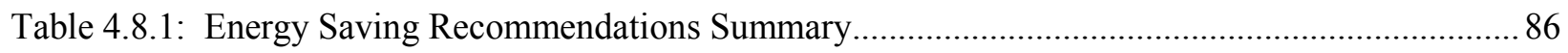

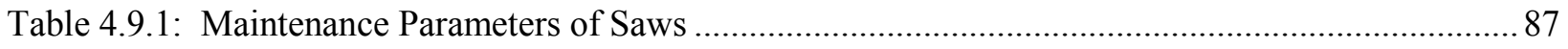

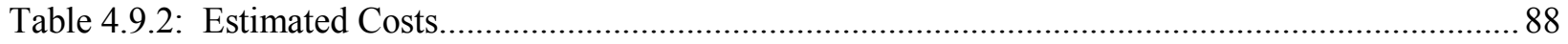

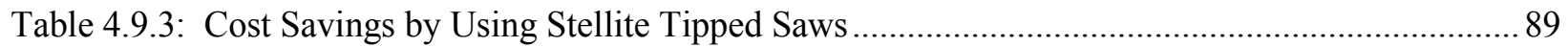

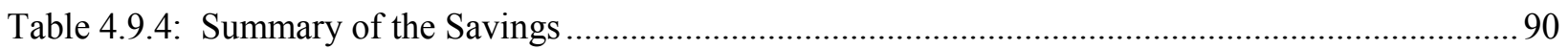

Table 4.10.1: Summary of the Specific Energy Consumptions ............................................................. 90 


\section{Nomenclature}

\begin{tabular}{|c|l|}
\hline BF & Board Foot \\
\hline MBF & 1000 Board Foot \\
\hline $\mathrm{kWh}$ & Kilo Watt Hour (Energy Usage) \\
\hline TWh & Trillion Watt Hour (Energy Usage) \\
\hline $\mathrm{kW}$ & Kilo Watt (Power) \\
\hline MMBtu & Million British Thermal Units $=293 \mathrm{kWh}$ \\
\hline SEC & $\begin{array}{l}\text { Specific Energy Consumption } \\
\text { (kWh/BF or kWh/MBF) }\end{array}$ \\
\hline CHP & Combined Heat and Power \\
\hline SCFM & $\begin{array}{l}\text { Standard Cubic Feet per Minute } \\
\text { (Volumetric Air Flow Rate) }\end{array}$ \\
\hline HP & Horsepower for the motor \\
\hline PF & Power Factor \\
\hline HVAC & Heating, Ventilation, and Air Conditioning \\
\hline RFID & Radio Frequency Identification \\
\hline &
\end{tabular}




\section{Introduction}

\subsection{Introduction to Sawmills}

Before the invention of sawmill, cants and lumber were made by pit sawyers and hewers who used to saw and plane the logs. In the late 1700s, sawmill equipment was powered by water and steam. The sawmill industry began to change rapidly after invention of the band saw in 1850, sawmills became highly mechanized to handle big logs and high volumes. In the twentieth century, introduction of electricity and latest technologies like microprocessors, programmable controllers and computers advanced the manufacturing process in sawmills and improved the productivity and efficiency [1]. The principal output of a sawmill is green sawn lumber or dried lumber which is used in construction and furniture industries. West Virginia currently has approximately 64 sawmills that produce various grade lumber from different hardwood species [2]. The sawmill owners that have remained in business over the last economic decline have been exploring ways to reduce the costs associated with the production of lumber. One potential way to lower costs is to focus on increasing their energy efficiency [3].

\subsection{Energy Sources in Sawmill}

The most commonly used energy sources in a sawmill are electricity, natural gas, wood waste, and sometimes fuel oil and diesel. Electricity is the major energy source in green lumber sawmills whereas natural gas and wood waste are the major energy sources in dry lumber sawmills. Electricity is needed for all sawing operations and material handling whereas natural gas and wood waste are used to produce steam in boilers for kiln for drying operation. Being the main electrical energy consumers in a sawmill, motors are the apparent candidates for the energy analysis to determine energy savings potential. It is important for sawmill owners to know the specific energy consumption of motors per board feet of a particular size lumber ( $\mathrm{kWh}$ per bf) produced of a specific species to know the energy efficiency of their manufacturing process. Energy efficiency cannot be improved without the knowledge of standard energy consumption for a particular species and size lumber; sawmill owners can benchmark their energy consumption against other sawmills and this will help to save energy in their operation. The specific energy consumption per board feet of various species helps in predicting baseline electrical energy consumption based on required 
production rate. This research is mainly focused on developing sawing electricity consumption profiles and hence data were collected in green lumber hardwood sawmills.

\subsection{Motors Energy Consumption}

Ninety percent of the electrical energy used in a typical sawmill is consumed by motors [4]. The typical breakdown of electricity usage in an average sawmill is shown in Figure 1.3.2 [5].

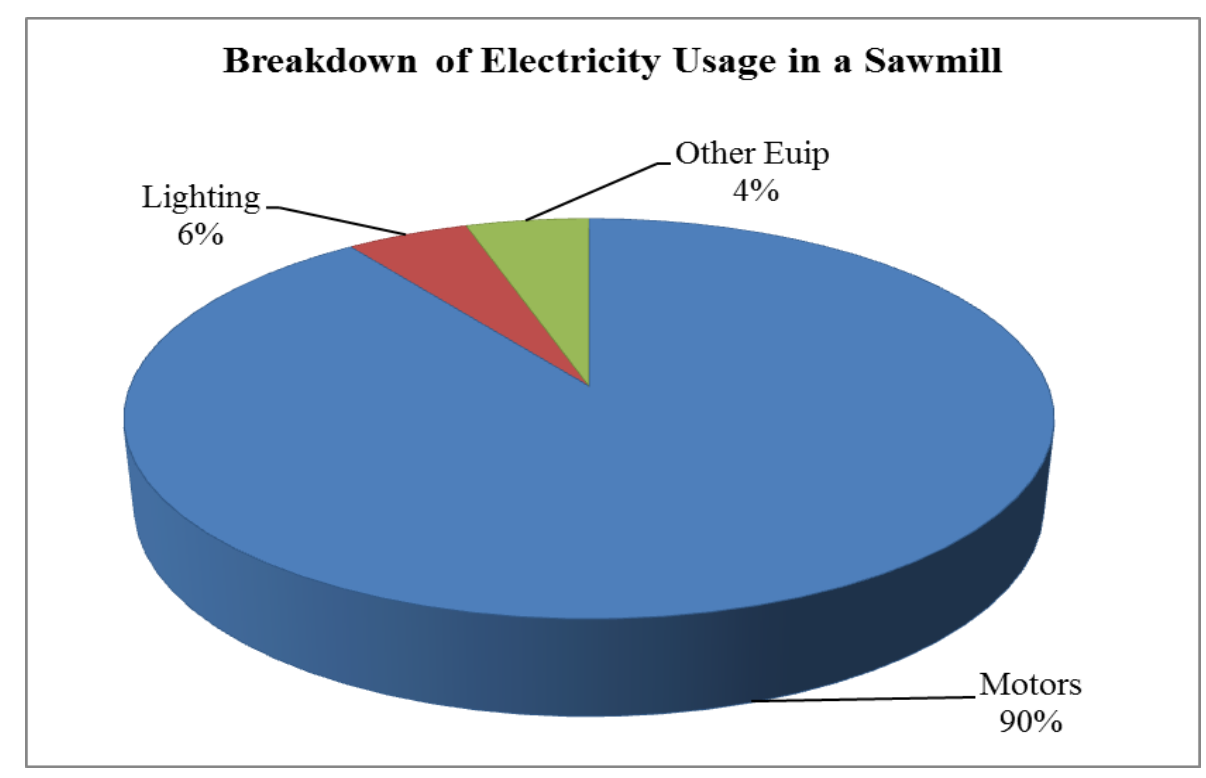

Figure 1.3.2: Electricity Usage in a Sawmill

Each sawmill has equipment run by large sized motors. The most common equipment used in sawmills are a de-barker, head saw, head saw carriage, re-saw, edger, trimmer, planer, and chipper. In addition, each sawmill would have an air compressor that would typically have power ranging from 100-300 horsepower. Smaller sized sawmills will usually have similar equipment but the power of the individual motors may be smaller. The power consumption of the miscellaneous motors in sawmills can also be significant. Typical breakdown of electrical energy usage of motors (i.e 90\%) in a sawmill is shown in Figure 1.3.3 [6]. 


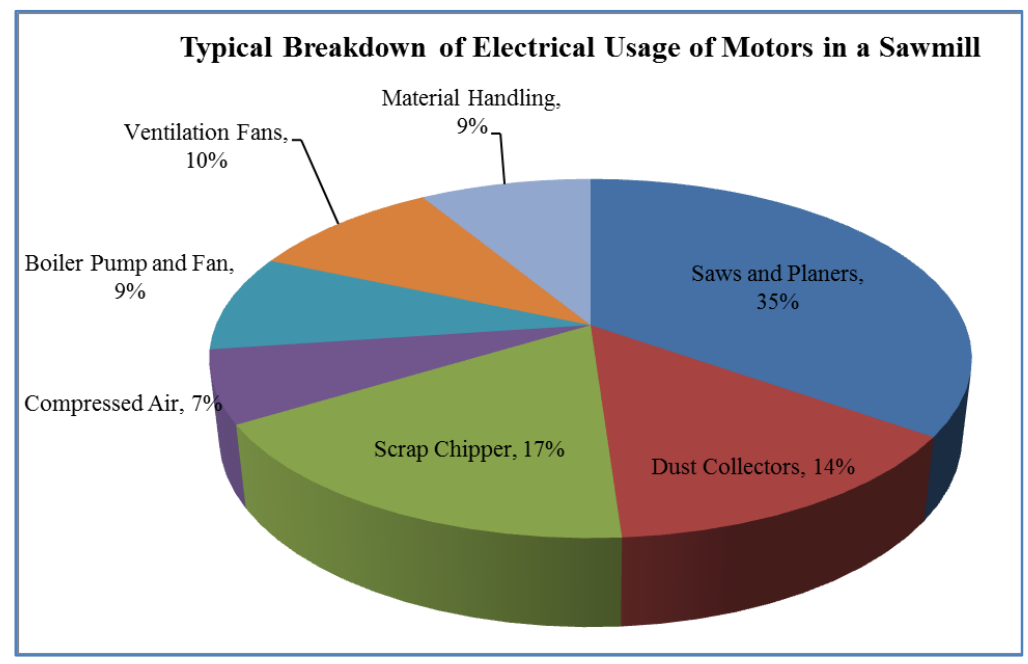

Figure 1.3.3: Electricity Usage of Motors in a Sawmill

Saws and planers are the major energy consumers which accounts for $35 \%$ of the total electricity consumption in a sawmill. In a typical sawmill, energy costs account for $10 \%$ of the total operating costs. Log costs can be as high as $60 \%$ of saw mill operating costs which includes tree cost, harvesting cost, and transportation cost. Labor and overhead costs can be $15 \%$ each of the total operating costs in a sawmill [4].

\section{Saw Mill Operating Costs}

Energy, $10 \%$

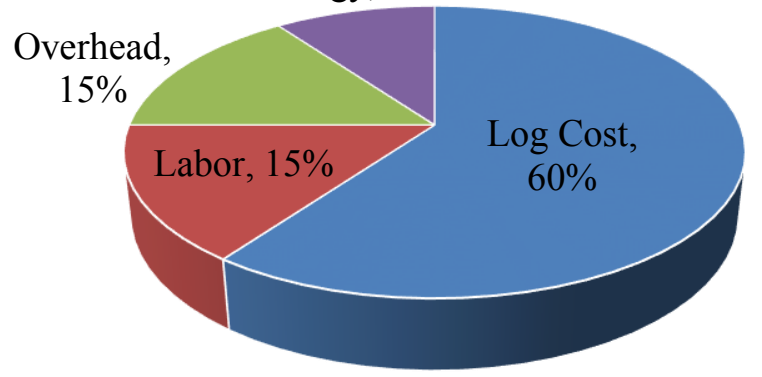

Figure 1.3.4: Breakdown of Sawmill Operating Costs 


\section{$1.4 \quad$ Need for Research}

With increasing energy prices, understanding energy consumption in sawmills is an important component of their efficient operation. In green lumber sawmills, $90 \%$ of the electricity is consumed by motors alone. It is important for a sawmill owner to know the specific energy consumption of motors per board feet of a particular size lumber ( $\mathrm{kWh}$ per bf) produced of a specific species. Overspending on energy can become very expensive which leads to higher operating costs. There has been very little empirical work completed on the impacts of the energy consumption per board feet on economics in sawmills. Likewise there are no standard energy consumption profiles developed for particular sizes and species of lumber. Knowing the standard energy consumption for a particular species and size lumber, sawmill owners can better understand their operating costs and this might open some opportunities to save energy in their operation. The selling point for energy efficiency is its direct contribution to the bottom line profit for a company. The other options are costlier and have higher uncertainty. For example, consider a facility with sales of $\$ 10$ Million. The profit margin and the energy cost for the company is about $10 \%$ or $\$ 1$ Million each. The facility has determined that through different energy projects it could easily reduce its energy cost by $30 \%$. This means a saving potential of $\$ 300,000$. So if the energy projects were implemented the annual profit for the company will be $\$ 1.3$ Million. To get the same profit the company has to increase the sales to $\$ 13$ Million or a $30 \%$ jump. Increasing sales is a harder task as compared to implementing energy projects on existing systems. Increasing sales might involve investing in higher capacity machines, hiring new employees, and increased sales and marketing effort.

The energy saving potential of sawmill depends on current energy consumption and productivity. The higher the energy consumption and lower the productivity compared to industrial standard, higher will be the potential to save energy. There are some studies available to calculate theoretical energy consumption of motors involved in cutting logs based on the size of the motor, shaft speed, saw tooth parameters (kerf, bite per tooth, depth of cut, and width of cut) and wood properties (moisture content, specific gravity). Surveys conducted in different sawmills within West Virginia showed that the theoretical energy consumption is varying from actual energy consumption [4]. Several factors like idling time, low load factors of motors, types of wood species sawn, and wood properties etc. may affect the energy consumption. Real time energy consumption data are 
mandatory along with actual production data to calculate energy consumption per board feet of a particular size lumber.

\subsection{Energy Profiling in Sawmill}

In the state of West Virginia, energy intensity is an important aspect in lumber producing sawmills. This project aims to facilitate the accurate measurement of energy intensity in hardwood sawmills by means of energy analysis and diagnostics using various data acquisition devices on electrical motors used in the manufacturing processes. Three hardwood sawmills with various annual production quantities were selected for this research based on their willingness to provide production data and allow the research team to access their electrical panels to monitor electrical energy consumption. Along with the data collection, an energy assessment, which is the analysis of energy usage from receiving raw material to producing finished product, was done to develop conservative measures to save energy at current operation in each sawmill. The principle product of these sawmills is green lumber.

An energy assessment process started with discussions with the plant manager and maintenance personnel about their operation and equipment. Twelve months of energy bills were collected to note anomalies. A questionnaire was developed to collect the data of manufacturing process, equipment details, operating hours, production details, etc., Information was collected on different types of wood species processed and sizes of lumber produced in the facility. A plant tour in the facility from raw material (logs) to finished lumber helped to understand the process and to generate major energy consuming equipment list.

Data loggers were installed for a period of one month to record amperage data of main motors for every minute. Different types of energy diagnostic equipment were used to monitor energy parameters like voltage, power factor, and kW. Furthermore, these energy diagnostic equipment's specifications are explained in Chapter 3.

\subsection{Research Approach and Objectives}

Onsite electrical, production data logging and research with respect to the major motors operating the equipment at three sawmills were performed. These data loggers collected amperage data of main motors for every minute over a period of one month. The collected data were downloaded on the computer and analyzed to develop energy profiles for each type of product being 
manufactured by the sawmills. An energy profile gives energy consumption for the family of products of a particular species. The term energy profile as used in this research refers to the complete energy usage by different manufacturing equipment in the production of specific size lumber of a specific species of wood. It is hypothesized that this energy profile will vary based on the size and species manufactured. The objectives of this research are:

1) Develop energy profiles and specific energy consumption for specific species

2) Develop energy profiles for different sizes of lumber sawn within the sawmills

3) Compare and generate knowledge on specific energy consumption of different species and different sizes among three sawmills

4) Compare energy consumption of major sawing equipment between different sawmills

5) Develop energy saving opportunities and productivity improvements for current operation in data collected sawmills

\subsection{Sawmill Operations}

The principal product of sawmill is green lumber or dry lumber. The raw material is logs from different species of hardwood. These logs are debarked, then sent to the head-saw and re-saw for the production of lumber. The lumber produced is edged, and trimmed. To produce dry lumber, the sawn lumber is sent to kiln for drying operation. Figure1.7.1 shows typical manufacturing processes for producing green lumber in a sawmill. 


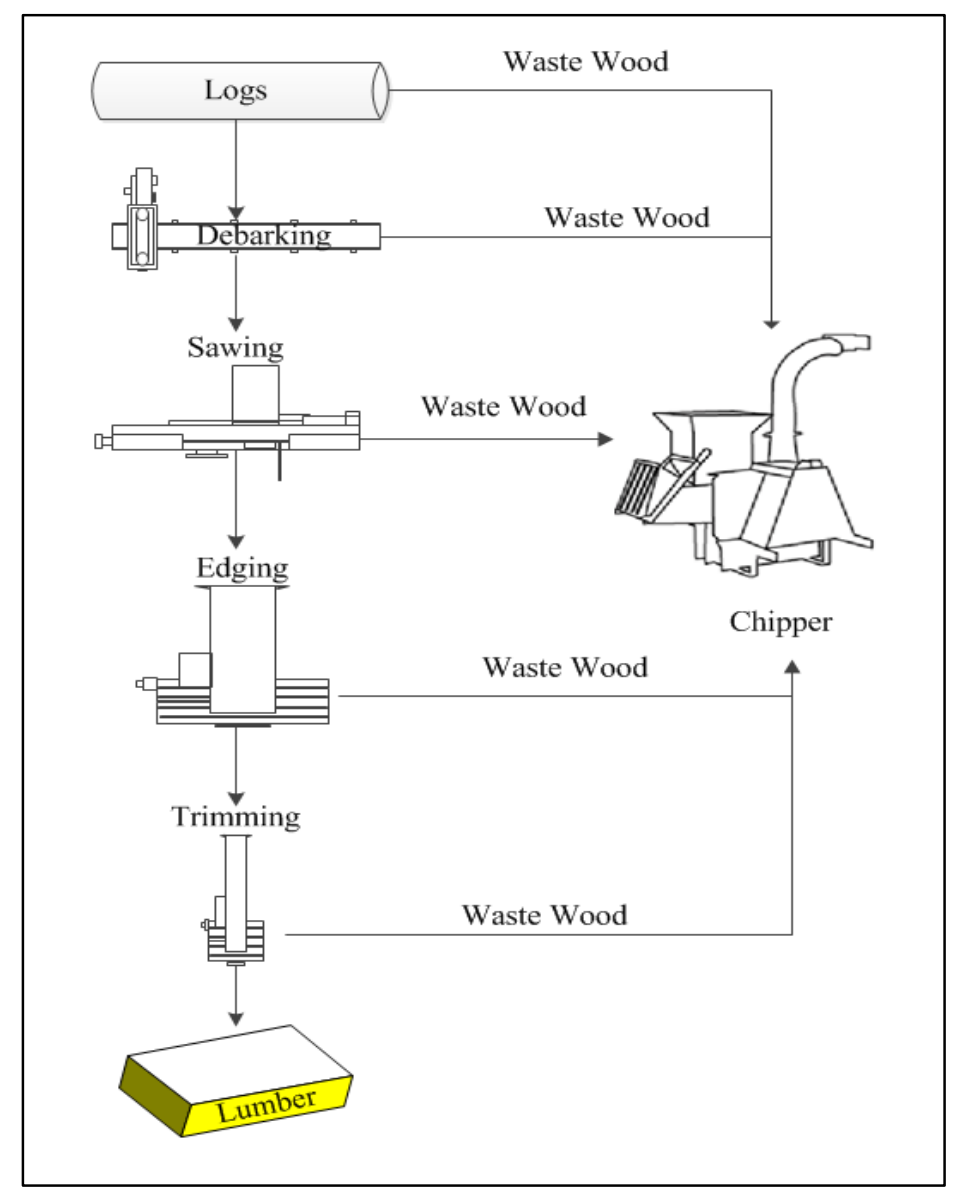

\section{Figure 1.7.1: Process Flow for Sawmill Operations-Green Lumber}

\subsubsection{Debarking}

Debarking is an essential and initial operation that should be done in any sawmill to produce the lumber. Debarking is a process involved in removal of bark from the logs. This bark can be used in pulp industries or chipped into small pieces to produce biomass fuel. The debarking operation helps to expose wood surfaces for better log cutting decision and also increases the life of sawmill cutting tools. Debarking prevents the saws and other equipment from wearing and damage that might happen because of the nails and other metal products embedded in the bark [7]. The equipment used to perform this operation is called a debarker. The main purpose of the debarker is to remove maximum possible bark and minimum amount of wood from the log. The common types of debarkers that are available in the market are cambio, ring, rosser-head, oscillating hydraulic, ring hydraulic, and drum type debarkers [8]. Rosser-head is the most widely used debarker in the sawmills. Each debarker has its own advantages and disadvantages and they can 
be chosen based on the type of sawmill and diameter of the log being processed. Figure 1.7.2 shows the rosser-head debarker and ring debarker.
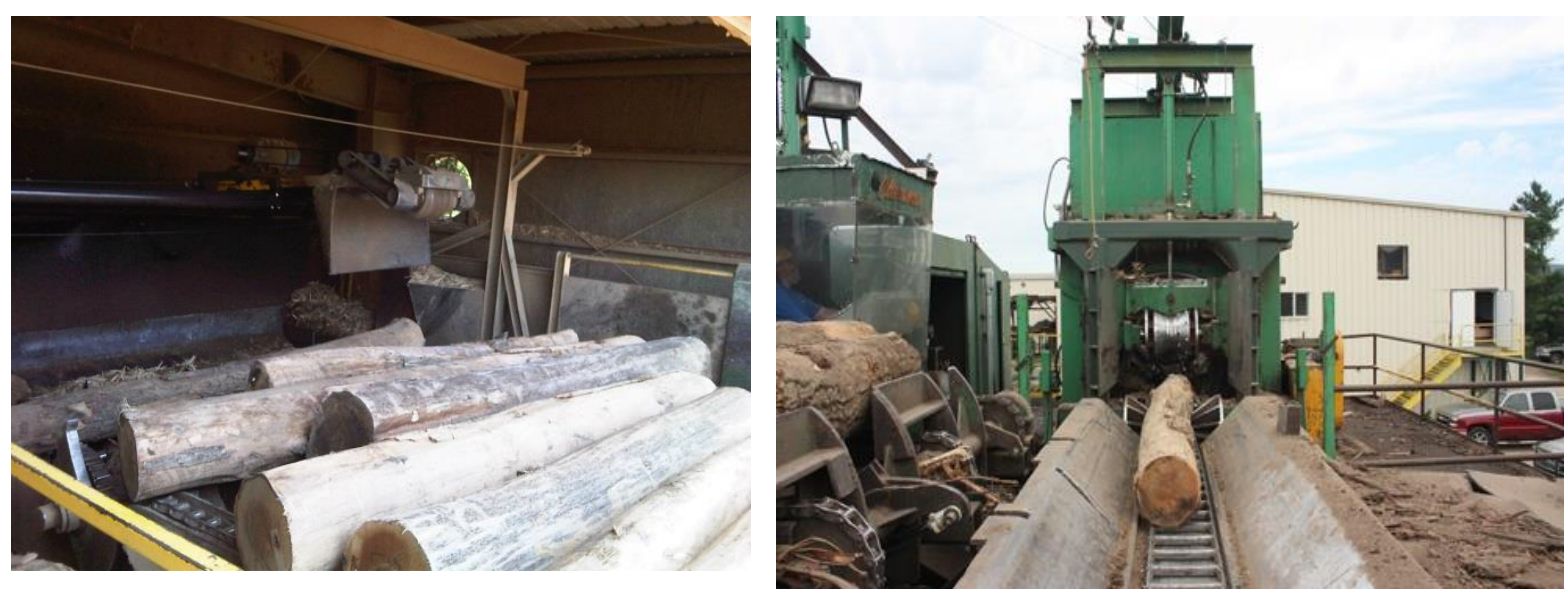

Figure 1.7.2: Rosser-head debarker on the left and ring debarker on the right

\subsubsection{Sawing}

Debarked logs are further sawn into boards, planks, or cants by using the head saw [9]. Head saw types include band, circle, twin band, chip-n-saw, and sash gang. The most common are band and circular saws. The head saw is selected based on several factors like log diameter, thickness of the blade, wood species, or required production quantity [4]. A band saw has small blade thickness which reduces wastage and increases yield and quality. The band saw is ideal for any size of logs and on the other hand circular saw has limitation on the log diameter. For processing logs more than 60 inches, a top saw has to be added to circular saw. Due to these limitations, irrespective of high capital cost, band saw is widely preferred over circular saw. Figure 1.7.3 and 1.7.4 shows typical band saw and circular saw respectively.

Sawn cants or boards from head saw are further cut into thinner lumber by using resaw or gang saw. The main purpose of re-sawing is to relieve the head saw and increase production. The most common types of resaws are vertical line-bar saw, tilted resaw, center split resaw, and horizontal resaw, whereas gang saws are classified as single arbor or double arbor saws [10]. 


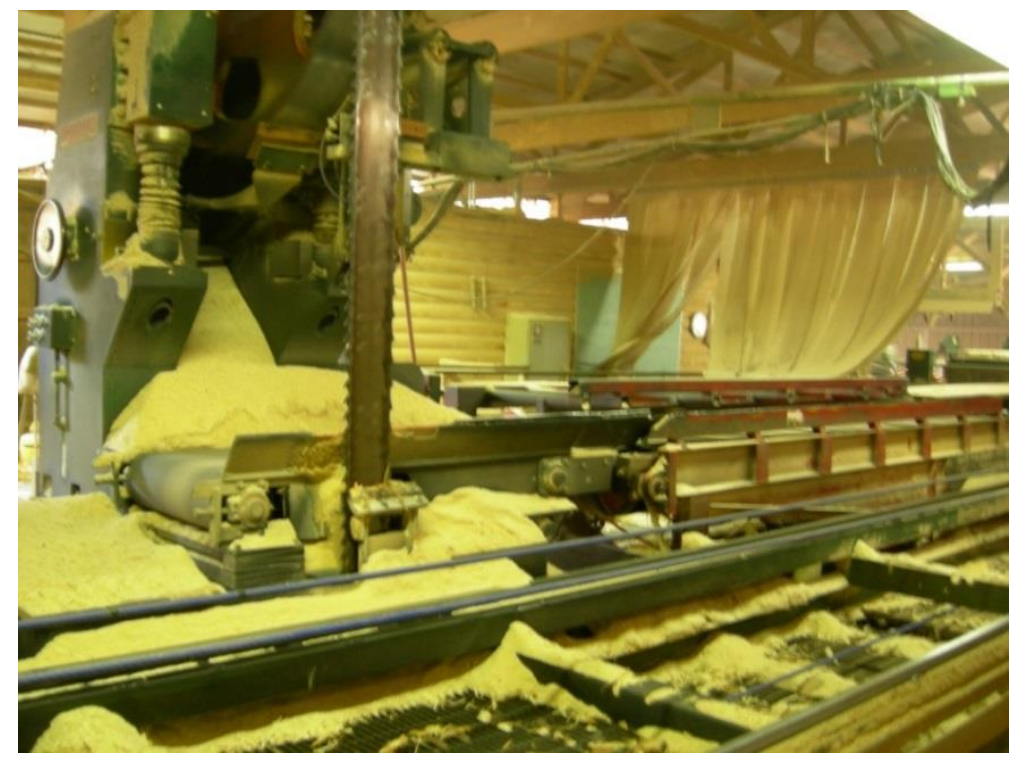

Figure 1.7.3: Typical band saw

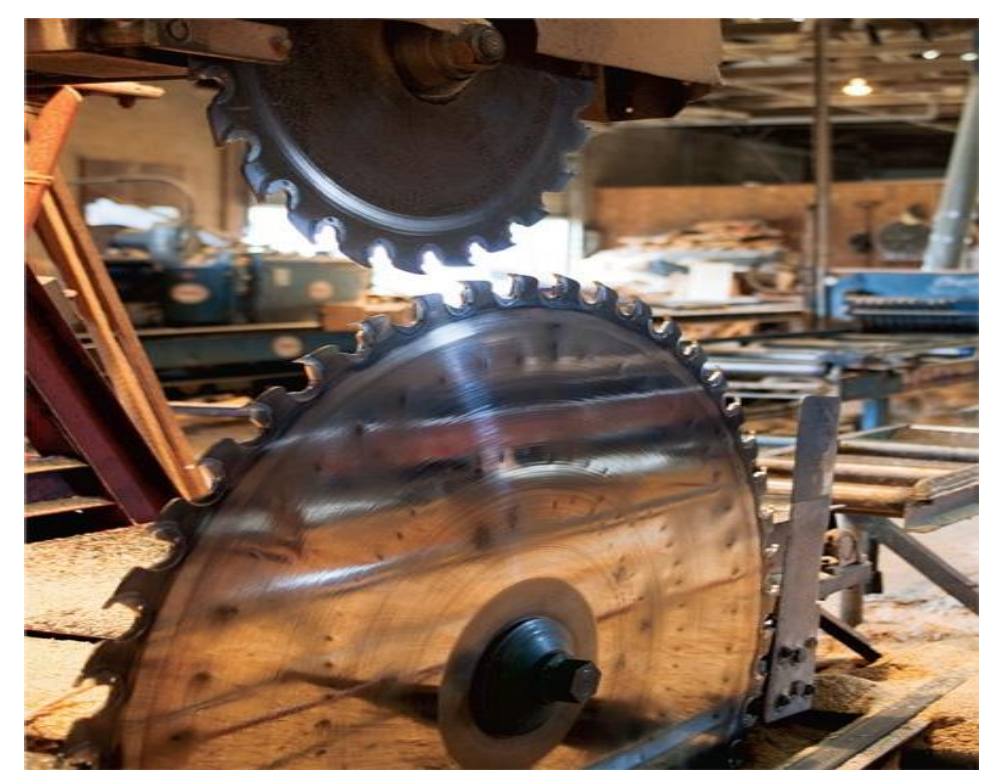

Figure 1.7.4: Circular Saw

\subsubsection{Edging}

Edging is the process of removing rough edges lengthwise on a lumber board to make it into a standard width. The equipment used for this process is called edger. The boards or cants from head saw or resaw go through the edger to remove defects left from previous processes and improve grade quality. An edger is a combination of feed mechanism and saws. Care must be taken while performing edging operation. Over removing material (edging) is a common bottle neck which can be very expensive to the sawmill and results in loss of wood and can reduce the grade of the 
edged boards [11]. Single and double saws are the common types of edgers available in the market. Two different thicknesses of lumber boards can be sawn at the same time by using double edger [10]. A typical edger operation is shown in Figure 1.7.5.

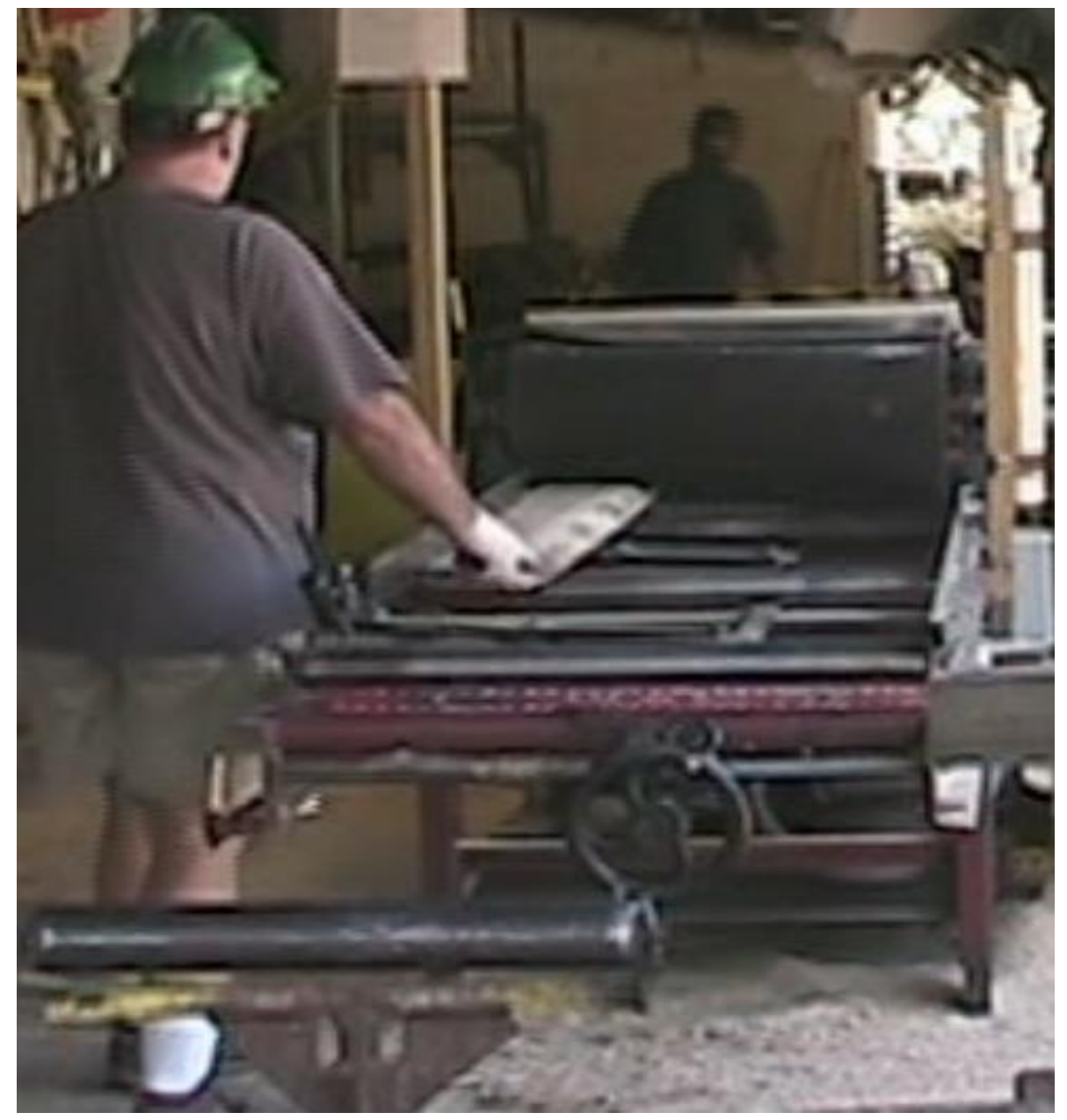

Figure 1.7.5: Double Saw Edger

\subsubsection{Trimming}

After the edger, lumber changes its direction by $90^{\circ}$ and enters into the trimmer. During the trimming operation, lumber is trimmed across the width to produce standard lengths. This process helps in eliminating gross defects. The most common types of trimmers are two-saw, Canadian style, and multiple-saw trimmers [12]. Two saw trimmer is common in small sawmills due to its low capital cost whereas multiple-saw trimmers are most commonly found in medium to high production sawmills. Canadian style trimmer is another type of two saw trimmer which can handle 
more logs. Like edging, care must be taken during trimming operation to avoid over trimming. Figure 1.7.6 shows the trimmer operation in Sawmill 1.

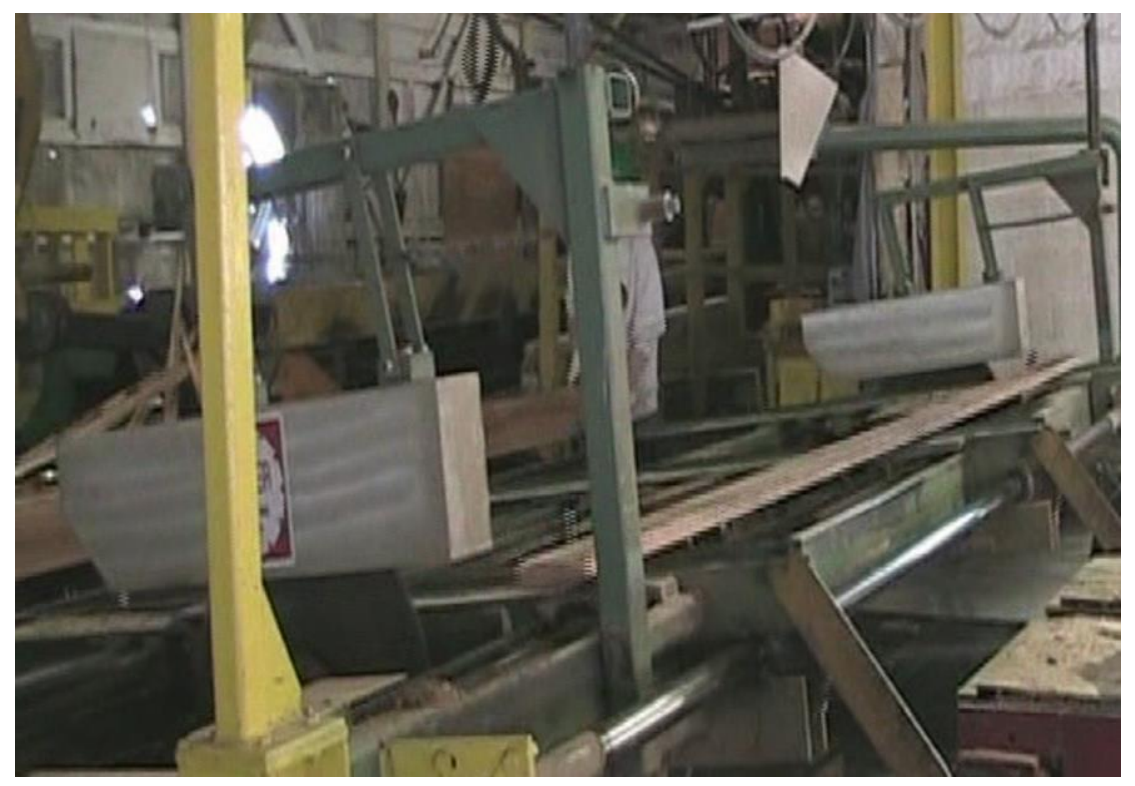

Figure 1.7.6: Trimmer

\subsubsection{Sorting and Grading}

After the trimming operation, lumber is sorted based on its quality, dimension, and species. Grading is often done by a certified grader on a sorting table. There are different grades of lumber produced by sawmills which are discussed briefly in Chapter 3. Sawmills use different methods for sorting. Some of the methods are green chain sorting, hand pull chain, and mechanical sorting [13]. Errors in sorting may cause inefficient kiln operation when lumber is kiln dried [14].

\subsubsection{Chipping}

Wood chips are valuable byproduct in a sawmill. Producing clean and uniform chips from waste wood can bring maximum profit to a sawmill. Wood chips are produced from different operations in a sawmill. Sawmill residues like bark from debarker, edged material from edger, slabs from head saw, trimmed ends from trimmer, and defective logs can be used to make wood chips [15]. Different types of chippers are used to make chips from wood waste. Some commonly used chippers are whole-log chippers, waste-wood disc chippers, and drum type chippers. Chippers are selected based on the size of the chips required and production rate required. Wood waste within the sawmill is fed into chipper with the help of conveyors [16]. Sawmill owners get benefit by 
selling wood chips in the market or using it as a biomass fuel to produce steam or generate electricity onsite. Figure 1.7.7 shows a typical chipper operation.

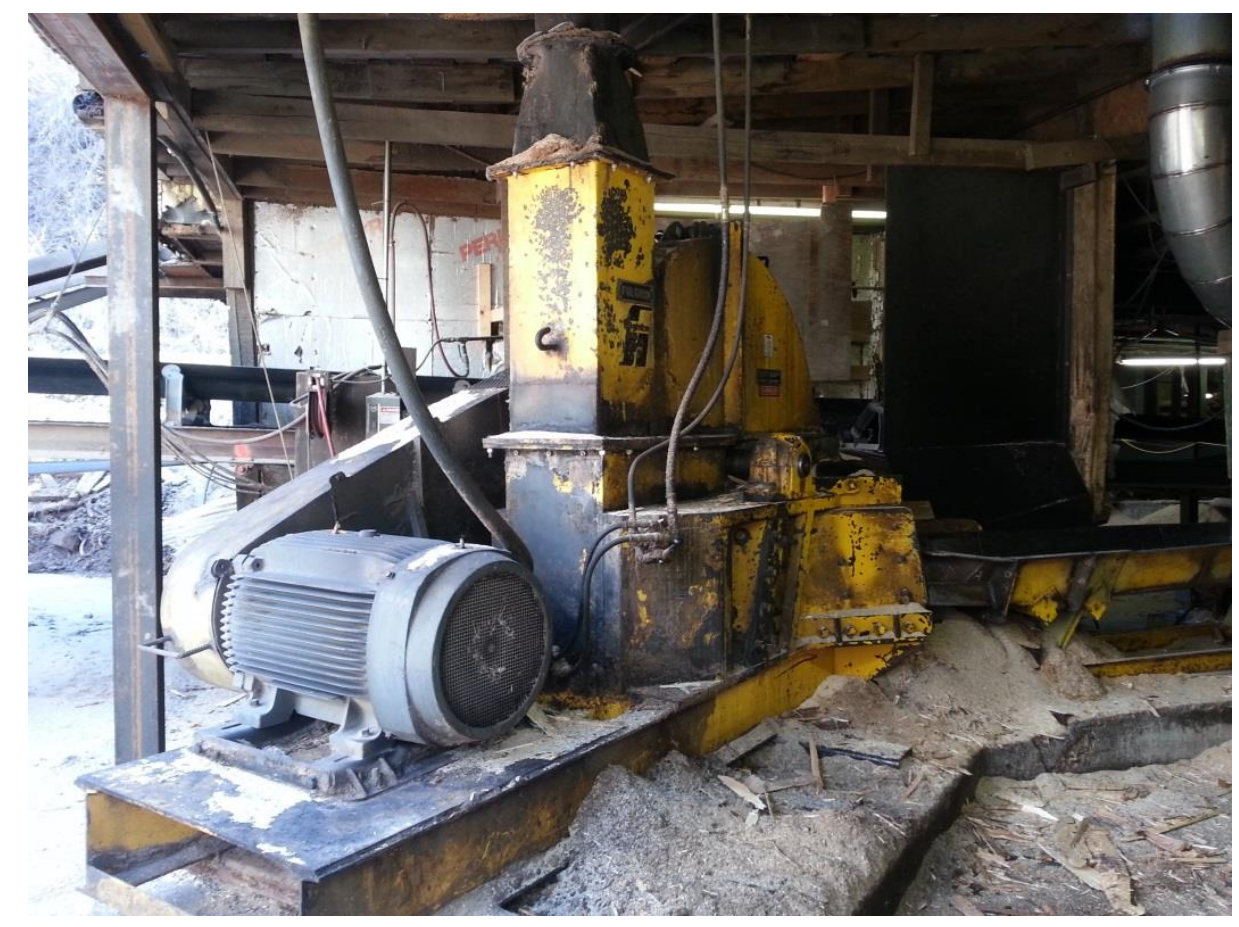

Figure 1.7.7: Disc Chipper

\subsection{Conclusion}

Energy Efficiency is an important aspect for lumber producing sawmills in the current scenario of increasing energy prices. Knowing specific energy consumption for a particular size of a particular species lumber will help sawmill owners understand their current energy efficiency and identify ways to save energy. Data were collected from 3 hardwood sawmills in West Virginia to develop sawing energy consumption profiles. Electricity and production data were collected on major motors for a period of 1 month. The undertaken study aims to produce baseline energy consumption figures for specific wood species to benchmark which would allow comparative evolution. To further improve the energy efficiency in a traditional way, energy assessments were conducted in these three sawmills. 


\section{$2 \quad$ Literature Review}

\subsection{Energy Profiling and Benchmarking in Sawmills}

Milota et al. [17] conducted a survey on life cycle inventory of softwood lumber production in four western mills and four southern mills of the United States. This research discusses the energy used for production of planed dry lumber and $\mathrm{CO}_{2}$ emissions. In this article the authors emphasize that even though the electrical energy accounts for major share in sawing, the maximum amount of energy consumption and $\mathrm{CO}_{2}$ emissions were due to drying process. In western sawmills, $53 \%$ of the mill electricity was spent in sawing. A total of $86.8 \mathrm{kWh}$ was spent to produce $1 \mathrm{MBF}$ of green lumber. The authors could not be able to divide the energy going in to sawing in southern mills from the survey. However, they were able to estimate the electrical energy spent to produce one MBF of planned dry lumber as $150.9 \mathrm{kWh}$ and $67.9 \mathrm{kWh}$ per one MBF of green lumber. A total of 924 pounds of $\mathrm{CO}_{2}$ was emitted in producing one $\mathrm{MBF}$ of planed dry lumber in western mills whereas 1,265 pounds of $\mathrm{CO}_{2}$ was emitted in southern mills. Milota et al. also estimated the total thermal energy consumed to produce $1 \mathrm{MBF}$ of planed dry lumber in western and southern mills. As per the study, to produce 1 MBF of planed dry lumber, a total 5.17 MMBtu of thermal energy which includes natural gas, coal, hydro energy, crude oil, uranium, and wood bark was spent in western mills whereas 6.07 MMBtu of thermal energy was consumed in southern mills.

Bergman and Bowe [18] conducted a survey in 20 northeastern mills to analyze the impact of producing hardwood lumber on the environment. The survey indicated that the thermal energy required to produce lumber was generated onsite whereas electrical energy was from both onsite and offsite sources. Based on the results presented in this paper, $399 \mathrm{kWh}$ of electrical energy and 12.96 MMBtu of thermal energy were spent to produce one MBF of planed dry lumber in these mills. For sawing operation, a total of $137 \mathrm{kWh}$ of electricity was consumed to produce $1 \mathrm{MBF}$ of lumber. This research also found that this energy spent varied widely with type of wood species sawn, age of equipment, and drying methods. The authors strongly believes that improving energy efficiency in sawmills can benefit them in both financial and environmental ways. Upgrading the equipment in sawmills can lower significant energy consumption and improve lumber quality. One more technology to reduce energy consumption was to use air drying methods before kiln drying. This paper also discussed about using computer techniques in sawing to reduce sawing errors. 
Most of the electricity and thermal energy used in sawmills were consumed by sawing operation and drying operation respectively. This study also states that using wood fuel that is generated onsite can lower the fossil greenhouse gas emissions.

Poole and Pinheiro [19] visited two saw mills in Brazil to develop energy profiles of motors. The kit of electrical data loggers, sensors and hand-held amperage meters were used to monitor the load profiles of motors. From the amperage data, the authors observed that the peak demand strongly varied among hardwood and softwoods. One of the important observations from the study was that the most of the motors were inefficient and could be replaced with new energy efficient motors. The authors strongly believed that there was an opportunity to use disconnect controls on some motors to reduce their energy consumption when they are running off-load.

Li, McCurdy, and Pang [20] performed a study titled "the energy demand in a sawmill". Energy consumption and production data of a sawmill which is located in New Zealand were collected for a period of one year. Three electrical meters were used to record the energy usage for every 30 minutes. Log dimensions and timber volume details were collected from the sawmill on a daily basis. From the results of this study, it was observed that the timber production increased as the thickness of the lumber reduced. To produce $1 \mathrm{MBF}$ of timber $\left(1 \mathrm{MBF}=83.33 \mathrm{ft}^{3}\right)$, the electricity demand for sawing was varying from $62 \mathrm{kWh}$ to $97 \mathrm{kWh}$ for the board thickness of 0.79 inches (20 mm) to 1.97 inches $(50 \mathrm{~mm})$.

Gopalakrishnan et al. [21] developed a model called "Baseline Electrical Energy Consumption in Wood Processing Sawmills" to identify the effect of production parameters on the energy consumption in sawmills. This model helps the facility personnel to estimate specific energy consumption in their sawmills. The analyst can run this model at different operating conditions to observe variations in energy consumption. Based on the data collected from different sawmills, the estimated specific energy consumption varies between 102.1 to $124.7 \mathrm{kWh} / \mathrm{MBF}$. The authors also has provided ways to save energy at current operation in the sawmill. 
Table 2.1.1: Energy Consumption to produce 1 MBF of Lumber from Different Studies

\begin{tabular}{|l|c|l|}
\hline \multicolumn{1}{|c|}{ Location } & kWh/1000 BF & \multicolumn{1}{c|}{ Source } \\
\hline Western Sawmills & 86.8 & Milota et al, 2006 \\
\hline Southern Sawmills & 67.9 & Milota et al, 2006 \\
\hline North Eastern Mills & 137 & Bergman and Bowe, 2008 \\
\hline New Zealand & 97 & Li, McCurdy, and Pang, 2006 \\
\hline West Virginia Sawmills & 124.7 & Gopalakrishnan et al, 2012 \\
\hline West Virginia Sawmills & 220 & Lin et al, 2012 \\
\hline
\end{tabular}

\subsection{Energy Efficiency -Sawmills}

Lin et al. [22] [conducted a survey in 58 sawmills in the Appalachian region on energy efficiency and energy consumption. This study emphasis the importance of energy efficiency in the sawmills as energy prices and energy supply are the major concerns in the recent world. The team also collected data from 17 hardwood sawmill energy audits done by the Industrial Assessment Center of West Virginia University. The collected data includes information of electrical energy consumption, major energy equipment, operating hours, and energy conserving opportunities in the sawmills. This study found that the average electrical energy consumed per sawmill is 220 $\mathrm{kWh} / \mathrm{MBF}$ and on an average 14\% of energy can be saved by implementing energy conserving measures.

Espinoza et al. [23]conducted a survey of 188 sawmills to find out the impact of high energy costs and actions taken by the sawmill owners to conserve energy and improve efficiency. This study indicated that $63 \%$ of sawmills are targeting to increase their energy efficiency and $41.9 \%$ sawmills are focusing on increasing their productivity and $41.3 \%$ sawmills are implementing both to cope up with the rising energy prices. Around $8.6 \%$ of sawmills indicated that they have established energy usage baselines and energy performance indicators which helps them to monitor their performance in a continual basis. This study stated that most of the sawmills were educating employees on energy efficiency. The most common efficiency measures discussed in this survey were improving lighting technologies, upgrading equipment with energy efficient equipment, and installing measures to minimize waste. The author stated that an increase in energy prices will build pressure on US hardwood products manufacturers to implement energy conserving measures. 
Bond [24] in his article talks about importance of the energy efficiency in sawmill industry as energy costs are raising immensely in the modern world. This article discusses about different energy conserving techniques such as using air-drying, using variable frequency drives on motors, recovering waste heat from kilns and boiler flue gases, and upgrading technologies. The article states that $10-15 \%$ of energy can be saved in a typical sawmill by implementing energy conserving measures recommended by the energy audits.

Anderson [25] in his thesis talks about improving energy conserving technologies in Swedish sawmills. This thesis states that the sawmill uses drying and heating operations for $12 \%$ of timber produced. As per this thesis, Swedish sawmills used 4.9 TWh (Trillion Watt Hour) of heat energy for drying purposes. Improving drying process can save substantial amount of heat energy. Hence, sawmills can be befitted by using this conserved thermal energy to generate electricity, heat and /or sell it to the market. The main technologies discussed in this study are recovering heat from the dryer stack, using mechanical heat pump, and implementing open absorption system. Implementing energy conserving technologies can save up to $5.56 \mathrm{TWh}$ of biomass energy depending on the operating conditions and existing equipment in the sawmill.

A case study [26] reported by Energy Saving International (ENSI) explains energy conserving methods that are adopted at one sawmill in Russia. In this facility, water based sorting line was replaced by automatic dry sorting line which resulted in significant electrical energy, thermal energy and water savings. Likewise, a wood fired boiler was installed in this mill to take the advantage of biofuel generated on-site. A total of 4,778 MMBtu (1.4 million kWh) of electrical energy savings and more than 119,000 MMBtu of thermal energy savings are reported in this study.

Wengert and Myer [27], in their article on the cost reduction and energy conservation in sawmills, explained the ways to reduce energy consumption without affecting the production. The authors believed that analyzing electricity bills and exploring other available rate schedules is the first step in saving money on utilities. Electricity billing and its basic components were briefly explained in this article. This paper explains different energy conserving methods that can be easily implemented in sawmills. The energy conserving methods discussed in this paper are related to electric motors, compressors, lighting, HVAC, boilers, and dry kilns. Sawmill owners are strongly 
encouraged to have energy audits in their mills which can help them to monitor energy patterns at different schedules and operations.

Anderson and Toffolo [28] in their article discussed an opportunity for integrating sawmills with pellet and CHP plants. They state that sawmills are the major wood residues supplier to pulp, paper, pellet and CHP plants. In a typical sawmill in Sweden, one fifth of the biomass (wood residues) produced is used for generating thermal energy to meet heating requirements. The remaining biomass is transported to other plants for production of pellets, thermal energy, or electricity. Overall energy efficiency can be increased by integrating sawmills, pellet plants, and CHP plants in a single field. By-products like sawdust, wood bark, wood chips of the sawmill were used as fuel in CHP plant. The electricity produced in the CHP plant was used to meet power requirements of sawmill and pellet plant. The waste heat was recovered from the flue gases of CHP plant and was used for sawdust drying in the pellet plant. It was noticed from the results that $18 \%$ of the sawmill by-products could be saved by integrating all the three plants in a single field.

Spinelli et al. [29] performed a study on the efficiency of drum and disc chippers. Two new chippers with same diameter were considered for the experiment. Same feed stock was fed for both disc and drum chippers. Four different feed stocks were used in this experiment with fifteen replications. A total of 120 tests were conducted to compare the productivity, power requirement, fuel consumption, and product quality of drum and disc chippers. During each repetition $100 \mathrm{~kg}$ of stock was fed into the chippers. Both the chippers produced considerably good quality product. Due to simpler design, disc chipper used 19\% less energy and found to be more energy efficient than drum chipper. The drum chipper was found to be more productive than disc chipper due its uniform energy usage for cutting all along the length of its knives. The results showed that feedstock type had significant effect on productivity and energy efficiency of both chippers.

\subsection{Energy Use in Sawmills}

Energy consumption is a critical aspect for today's manufacturing industries. Of the total energy spent by US manufacturing industry, $12 \%$ accounts for forest product sector. $5 \%$ of this percentage is consumed by sawmill industry (both softwood and hardwood mills) [24] and remaining 7\% accounts for other forest industries like paper, pulp and other wood products. As per the survey data from U.S. Energy information administration, sawmills used 232 trillion Btu of energy in 
2010 [30]. A total of 29,057 million board feet was produced during 2010 [31]. Figure 2.3.1 shows the expenditures of purchased fuels in the sawmills in 2010. Electricity cost accounts for $63 \%$ of the total energy costs ( $\$ 629$ millions) in the US sawmills [30].

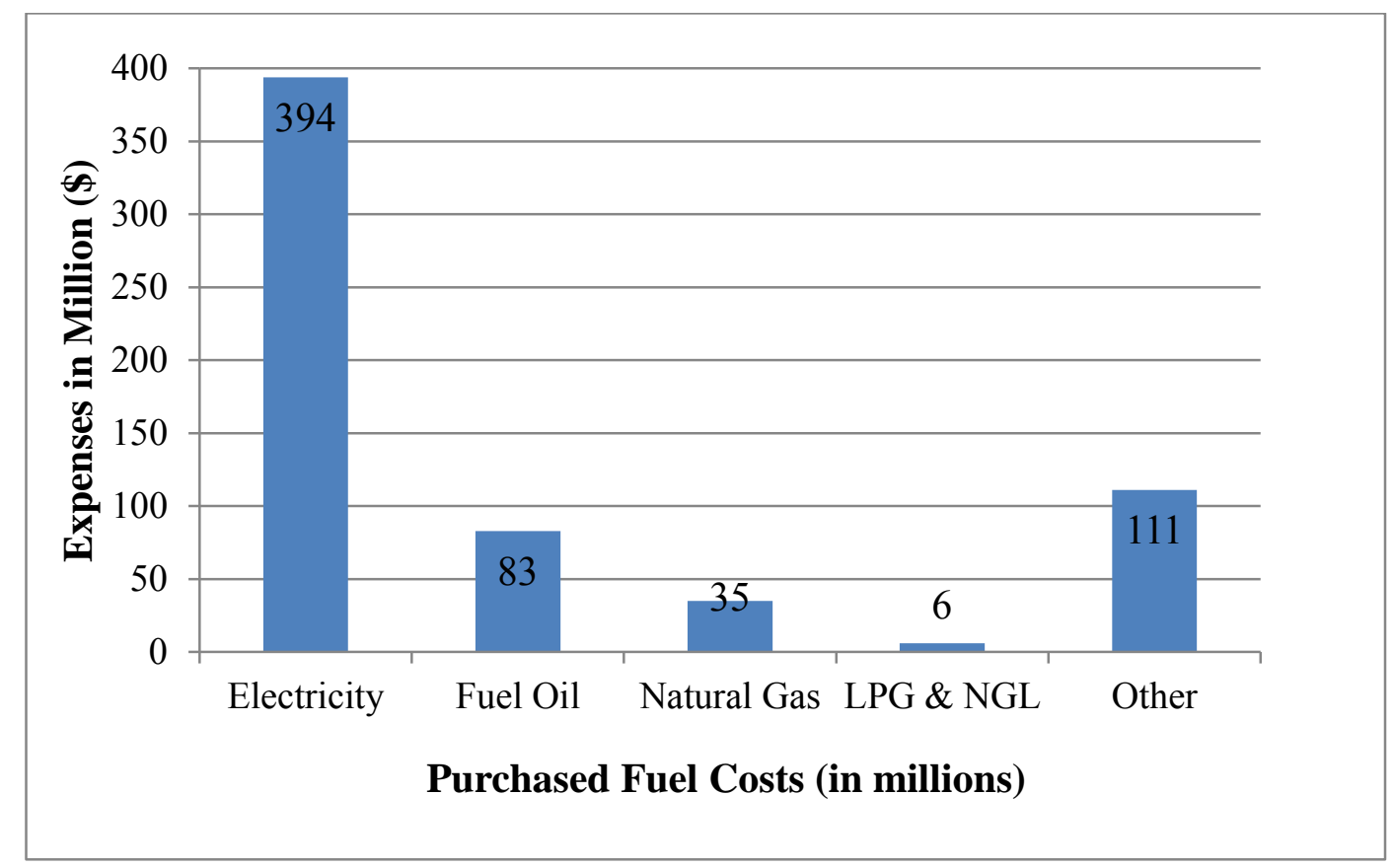

Figure 2.3.1: Energy expenses in the US sawmills in 2010

\subsection{Sawmills in West Virginia}

The United States Forest Products industry has suffered a prolonged decline in both economy and employment over the last decade. From 2004 to 2009, forest products economy in the southern region has declined by $24 \%$ and more than 110,000 jobs (35\%) were lost during 2005 to 2009 [32]. Since 2000, hardwood lumber production has declined by $25 \%$ in the United States [33] and in the Appalachian Region it has fallen by 40\% [34]. Although hardwood log and lumber markets are gradually improving, the West Virginia forest products industry is in one its worst economic situations in recent times. Not only has employment suffered, but so have prices for lumber and other end products, while raw material prices have not adjusted in-kind. These declines have impacted every portion of the forest to product value stream.

\subsection{Energy Assessments in Sawmills}

Gopalakrishnan and his team [5] conducted energy assessments in 17 hard-wood sawmills through Industrial Assessment Center, West Virginia University during 2001-2010. The major energy 
source was electricity. These assessments reported energy savings of $939 \mathrm{MMBtu}(275,000 \mathrm{kWh}$, $1 \mathrm{MMBtu}=293 \mathrm{kWh}$ ) of electricity and $916 \mathrm{MMBtu}$ of natural gas for sawmills with average annual energy consumption of 9,500 MMBtu. The reduction in greenhouse gas emissions would be around 353 tons of $\mathrm{CO}_{2}$ if energy conserving recommendations are implemented. $\mathrm{CO}_{2}$ emissions were calculated based on 2.19 pounds per one $\mathrm{kWh}$ of electricity and 113 pounds per one MMBtu of natural gas.

The Industrial Assessment Center at University of Chicago [35] conducted energy assessments in 10 pulp and paperboard manufacturing industries during 2001-2002. Significant energy conserving recommendations were developed to save energy as well as reduce greenhouse gas emissions. The major energy systems identified in these industries were motors, compressors, heating, lighting, and boilers. These 10 mills were consuming more than 153,584 MMBtu (45 million $\mathrm{kWh}$ ) of electricity and close to 500,000 MMBtu of natural gas. The reports resulted from these assessments included savings of $6 \%$ electricity, $12 \%$ natural gas, and 5,509 tons of $\mathrm{CO}_{2}$ emissions [39]. $\mathrm{CO}_{2}$ emissions were calculated based on 1.43 pounds of $\mathrm{CO}_{2}$ per one $\mathrm{kWh}$ of electricity and 117 pounds of $\mathrm{CO}_{2}$ per one MMBtu of natural gas.

US Department of Energy [36] reported a case study on compressed air system improvement in a sawmill. This facility is a typical sawmill that uses compressed air for pneumatic tools, moving logs, and cleaning purposes. There were three rotary screw type compressors of total capacity 650hp which were generating 2,000 scfm to 2,300 scfm of compressed air. The facility personnel along with AIRMaster+ specialist conducted compressed air survey to evaluate the system efficiency and energy conserving opportunities. The team discovered several opportunities to reduce energy consumption at both operating and maintenance procedures. Energy saving methods such as sequencing compressors, lowering the set pressure, and upgrading controls resulted in 4,437 MMBtu (1.3 million $\mathrm{kWh}$ ) of electrical savings. In a similar way, compressed air system was optimized and efficiency was improved in other sister plants and these efficiency measures resulted in a savings of around 23,208 MMBtu of electricity (6.8 million $\mathrm{kWh}$ ).

A study [37] was conducted by professional energy auditors in Australian sawmills to analyze the energy consumption. According to this study, the highest possibility of the energy savings in these sawmills could be achieved at the thermal supply. This study also indicated that the idling motors in these sawmills were causing more electrical energy consumption. Improving pneumatic system 
in these sawmills can save as high as $28 \%$ of its electrical energy consumption. The results were extrapolated for the whole Australian sawmill industry to roughly benchmark the savings. As per this study, as high as $25 \%$ of thermal energy and $8 \%$ electricity can be saved by applying energy efficiency technologies in the sawmill industry .

Table 2.5.1: Energy Savings in Sawmills from Energy Assessments discussed in Different Studies

\begin{tabular}{|l|c|c|l|}
\hline \multicolumn{1}{|c|}{ Location } & $\begin{array}{c}\text { Electricity } \\
\text { (MMBtu or } \\
\text { \%) }\end{array}$ & $\begin{array}{c}\text { Thermal } \\
\text { Energy } \\
\text { (MMBtu or } \\
\text { \%) }\end{array}$ & \multicolumn{1}{|c|}{ Source } \\
\hline Swedish Sawmills & 4,778 & 119,000 & $\begin{array}{l}\text { Energy Saving International, } \\
2007\end{array}$ \\
\hline West Virginia Sawmills & 939 & 916 & $\begin{array}{l}\text { IAC-West Virginia } \\
\text { University, 2010 }\end{array}$ \\
\hline $\begin{array}{l}\text { Pulp and Paper Board } \\
\text { Industries }\end{array}$ & 9,215 & 60,000 & $\begin{array}{l}\text { IAC-University of Chicago, } \\
2002\end{array}$ \\
\hline Weyerhaeuser Sawmill & 4,437 & - & US DOE, 2000 \\
\hline West Virginia Sawmills & $14 \%$ & - & Lin et al \\
\hline Australian Sawmills* & $8 \%$ & $25 \%$ & $\begin{array}{l}\text { Energy Efficiency in SME } \\
\text { (Small and Medium Sized } \\
\text { Enterprises })\end{array}$ \\
\hline
\end{tabular}

Energy savings are identified in terms of percentage of total energy consumption

\subsection{Conclusion}

The literature review gives an idea about importance of energy benchmarking and energy conservation in sawmills. It also presents different energy efficiency technologies that can be implemented in a sawmill. It is apparent that specific energy consumption was estimated based on the input provided by the facility personnel. Hence, it is clear that more specific information on individual motors as well as lumber production and its relationship to energy usage is needed. It is important for a sawmill owner to know the specific energy consumption per board feet of a particular size lumber (kWh per MBF) of a specific species. Thus, research in this area will be of immense help to sawmill owners to benchmark themselves against other sawmills in order to determine the potential of saving electrical energy in their operations. Sawmills can evaluate the impact of their production decisions on energy consumption using the results of this research. The research may also provide invaluable tools for sawmill decision makers for better economic planning since energy expenditure directly impacts the profit bottom line. 


\section{Research Approach}

It was necessary to monitor real time electrical data of electrical motors in a sawmill to calculate the specific energy consumption per board feet. The energy intensity determination was accomplished by data collection with respect to electrical energy consumption parameters as well as production system parameters. Three medium sized sawmills were selected for monitoring electrical energy consumption in different electrical equipment used to produce lumber. All three sawmills were powered by a three phase electric supply. The current, voltage, and power factor are main components in three phase supply that need to be monitored.

\subsection{Electrical Data Logging}

Different electronic data loggers with combination of sensors and transducers are used for real time data monitoring. AC (Alternating) current is the important parameter of three phase power supply in calculating real time power consumption by motors. During first session of the visit, an advanced data collection device i.e. AMPROBE was used for approximately 30 minutes on each of the electrical motors. AMPROBE is a device which is capable of recording AC voltage, AC current, power factor and peak demand $(\mathrm{kW})$ of three phases simultaneously [38]. Power factor is a ratio of true power to apparent power and it measures power quality. Three legs of the AMPROBE were connected to each phase in the control panel of the motors. Due to its limited storage, monitored data were downloaded immediately to a personnel computer by using Download Suite software after each motor's data collection. This device was used to find the power factor values and compare $\mathrm{AC}$ current data with continuous monitoring equipment. As it needs lot of connections and ample space in the control panel, this device was not used on some motors due to limited space in the control panels. In that case, a hand held clamp on meter (Power Meter) was used to collect power factor values. A hand held clamp on meter is a portable device that can be used to collect instant readings of AC current, voltage, and power factor values and is shown in Figure 3.1.1 and Figure 3.1.2. A screenshot of Download Suite software is shown in Figure 3.1.3. 


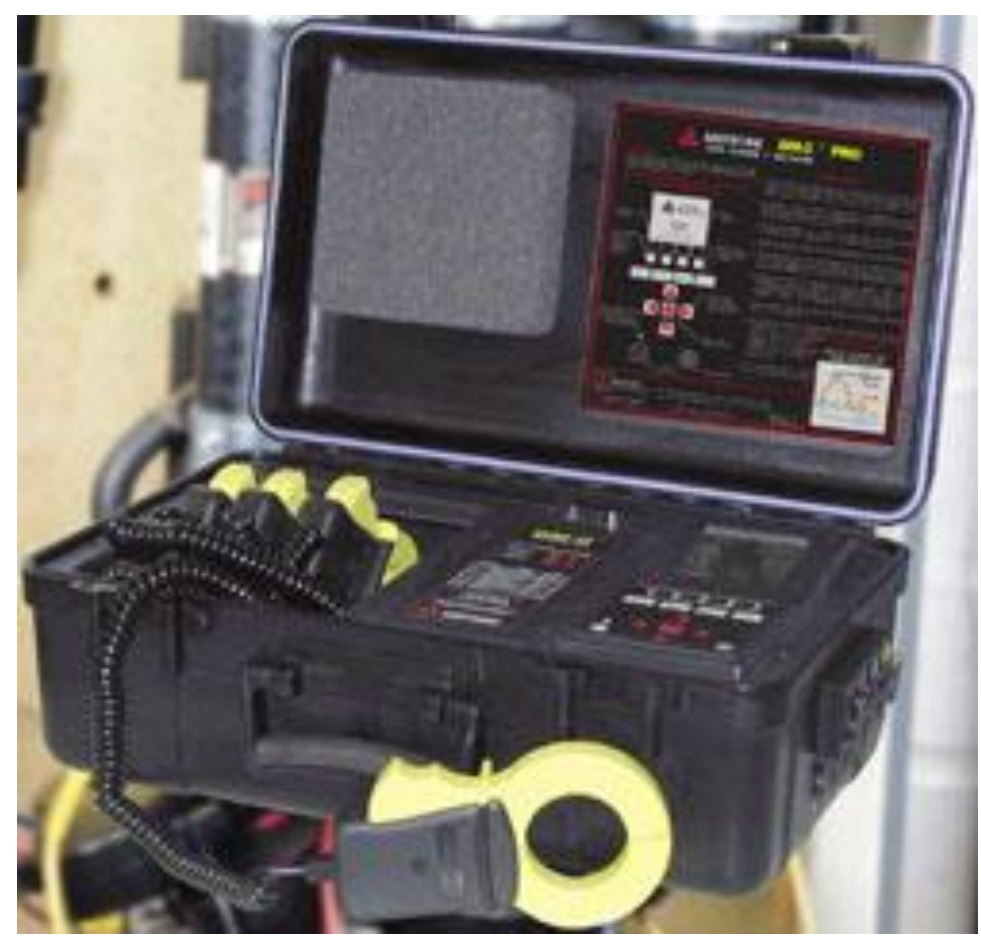

Figure 3.1.1: AMPROBE Device

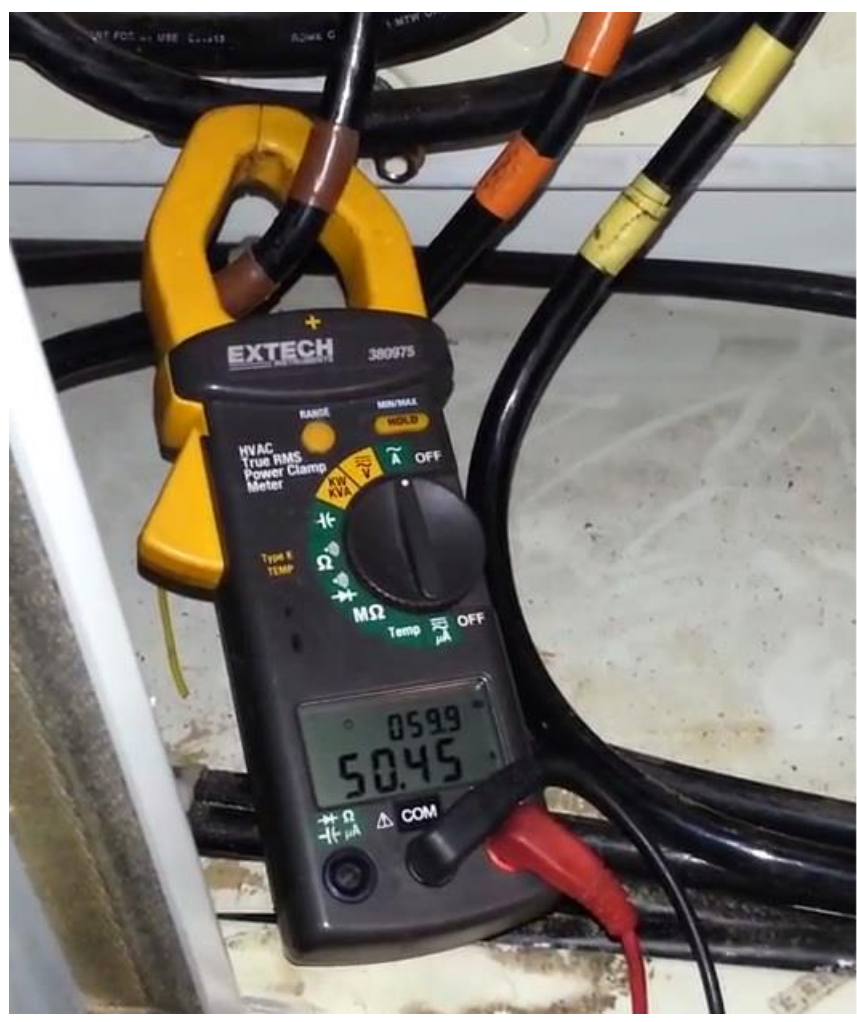

Figure 3.1.2: Clamp on Meter 


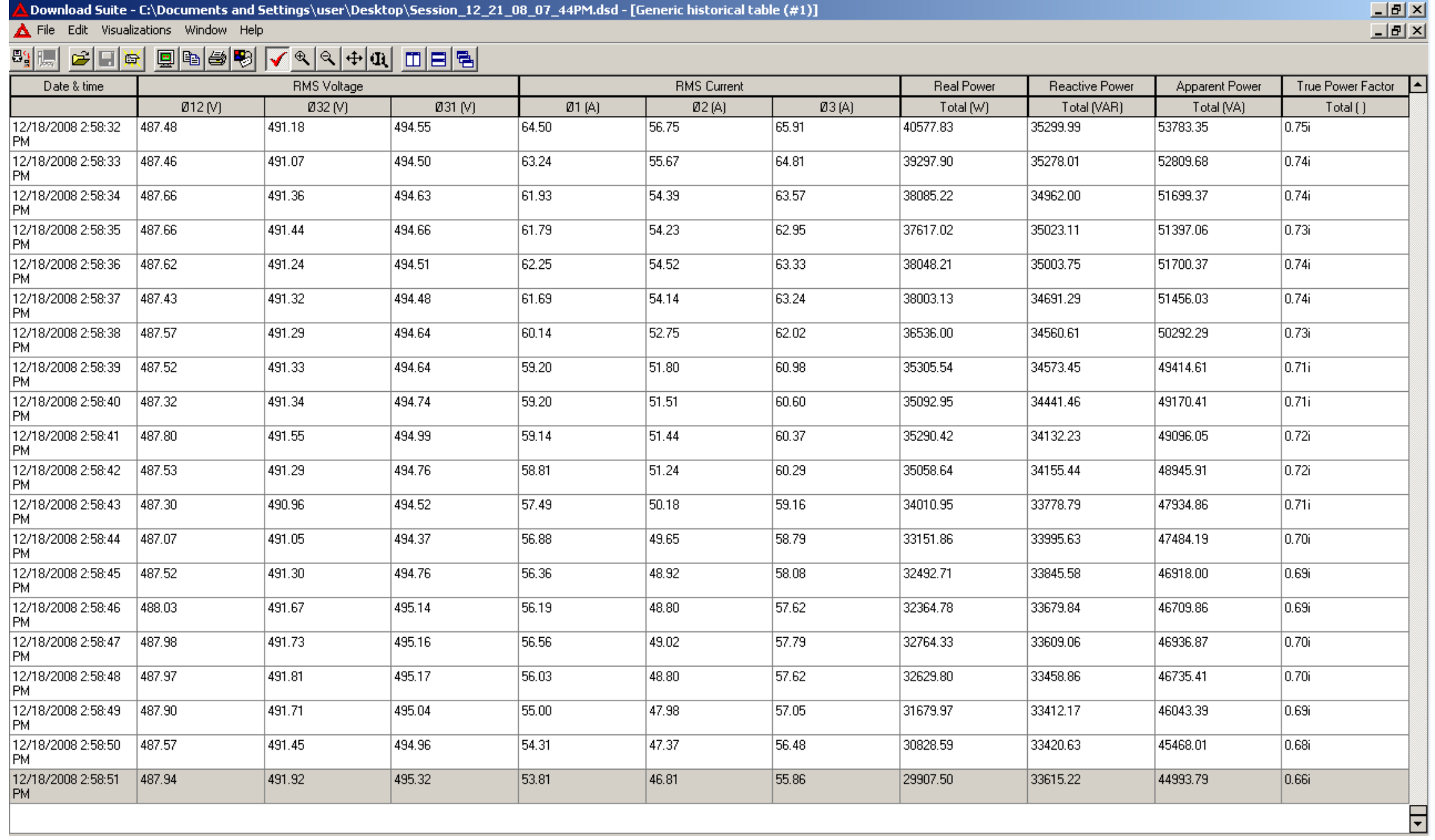

Figure 3.1.3: A Snapshot of Download Suite Software 


\subsubsection{Continuous monitoring equipment}

A HOBO data logger was used in conjunction with transducer for real time amperage data collection of the motors. A HOBO is a four channel device that can be used for recording temperature, relative humidity, light levels, $\mathrm{AC} / \mathrm{DC}$ current and $\mathrm{AC} / \mathrm{DC}$ voltage with or without combination of other sensors. This four channel device is powered by 3 volt lithium battery and can record up to 43,000 samples. It has a memory of $64 \mathrm{k}$ bytes. This device needs a USB (Universal Serial Bus) interface to initialize and readout data by a personnel computer. As per manufacture's specifications, it is suitable to use in atmospheric temperatures between $32{ }^{\circ} \mathrm{F}$ to $122{ }^{\circ} \mathrm{F}\left(0^{0} \mathrm{C}-50{ }^{\circ} \mathrm{C}\right)$. Figure 3.1.4 shows a four channel data logger used for data collection [39]. Software called HOBOware Pro from Onset Comp is necessary to launch the unit.

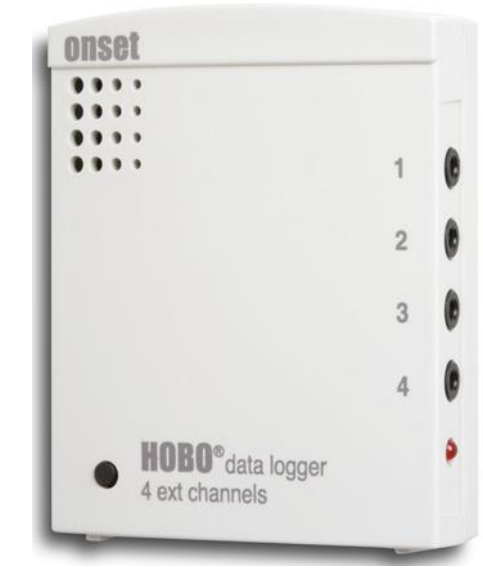

Figure 3.1.4: A four channel data logger, НОВО

Split-core current transducers (CTV-D and CTV-E) [40], which were connected to one phase of the motor's control panel, are shown in Figure 3.1.5. Any of the three phases can be used for data logging. Due to limited data loggers, current was monitored on one phase. The device CTV-E can measure AC current over a range of 60-600 Amps and is suitable for voltages less than $600 \mathrm{~V}$ AC. CTV-D is suitable for small size motors and can measure AC current up to $200 \mathrm{Amps}$ and requires less space in the electrical control panel. This small transducer is ideal for control panels where space between the phases (legs) is limited. 

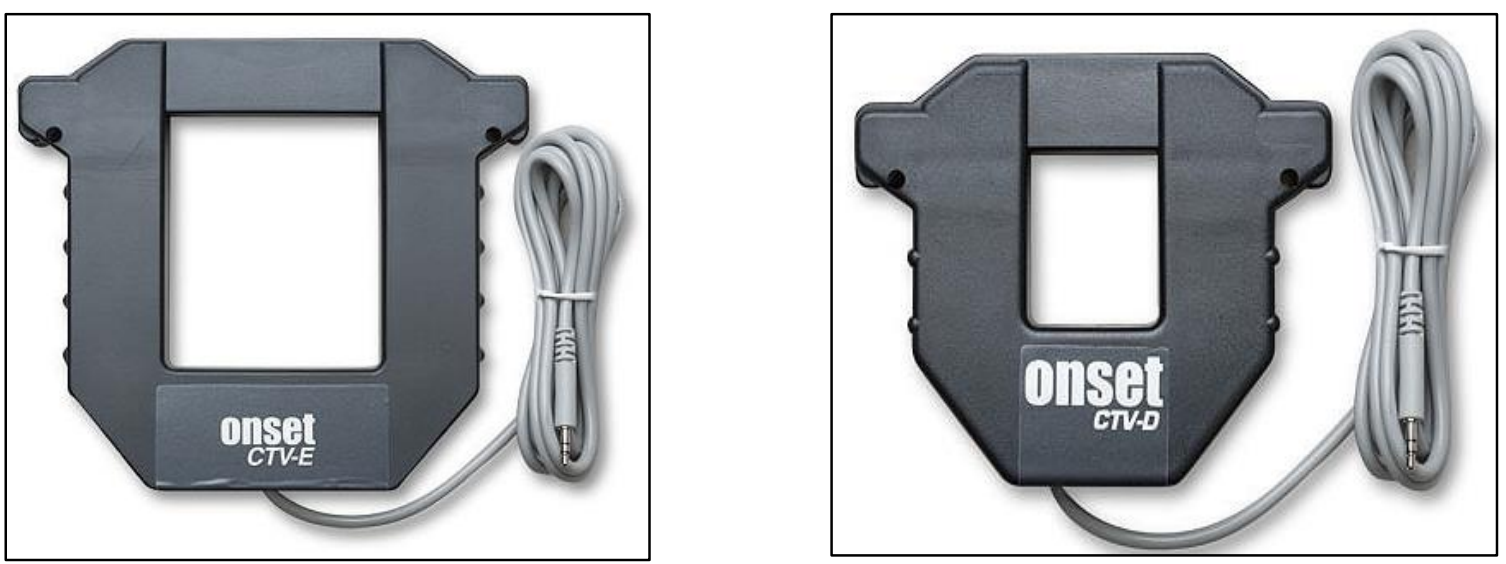

Figure 3.1.5: Current Transducers for 600 Amps and 200 Amps

Current transducers use 0.1 inch width jack to connect with external data logger (HOBO) and transmit signal in 0-2.5 V DC form. Then external data logger translates this signal to proportional amperage. A real time data monitoring setup is shown in Figure 3.1.6. These transducers with external data loggers were installed on major electrical motors of each sawmill for a period of one month.

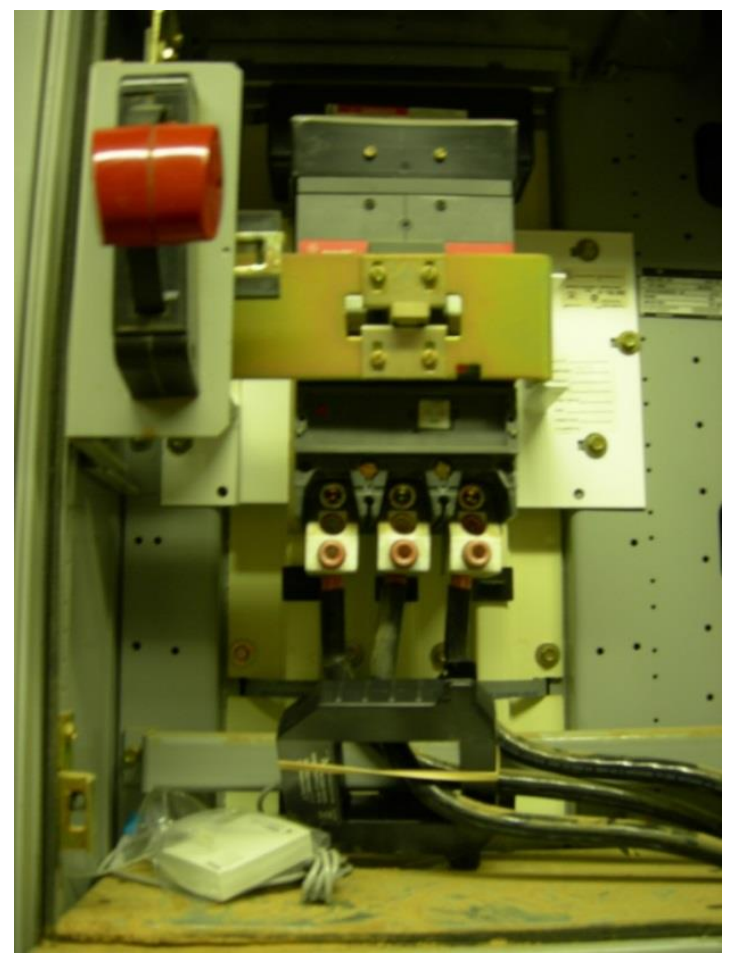

Figure 3.1.6: Data Monitoring Setup 
The data loggers require HOBOware software to initialize the unit, which is called launching, and downloading the collected data to the computer. The snapshot of software screen is shown in Figure 3.1.7. As shown in the screenshot, the equipment description, the channel number to be used for collecting the data, the type of transducer to be used, the logging time interval between successive measurements, and the starting time of data logging needs to be provided. Based on the provided time interval for data logging, the software calculates logging duration for the parameters selected. The user can have multiple options to start the data logger. It can start recording the data at pre-defined time or at some delayed time or immediately by pressing the push button. The data loggers were initialized to collect the data every minute. The recorded data were downloaded to a personnel computer by using USB cable. The recorded data were available in both tabular and graphical formats. Figure 3.1.8 shows a graphical form of collected data. The user can also export the data to an Excel spread sheet for further data analysis to calculate energy consumption and/or to identify peak demand of the motor.

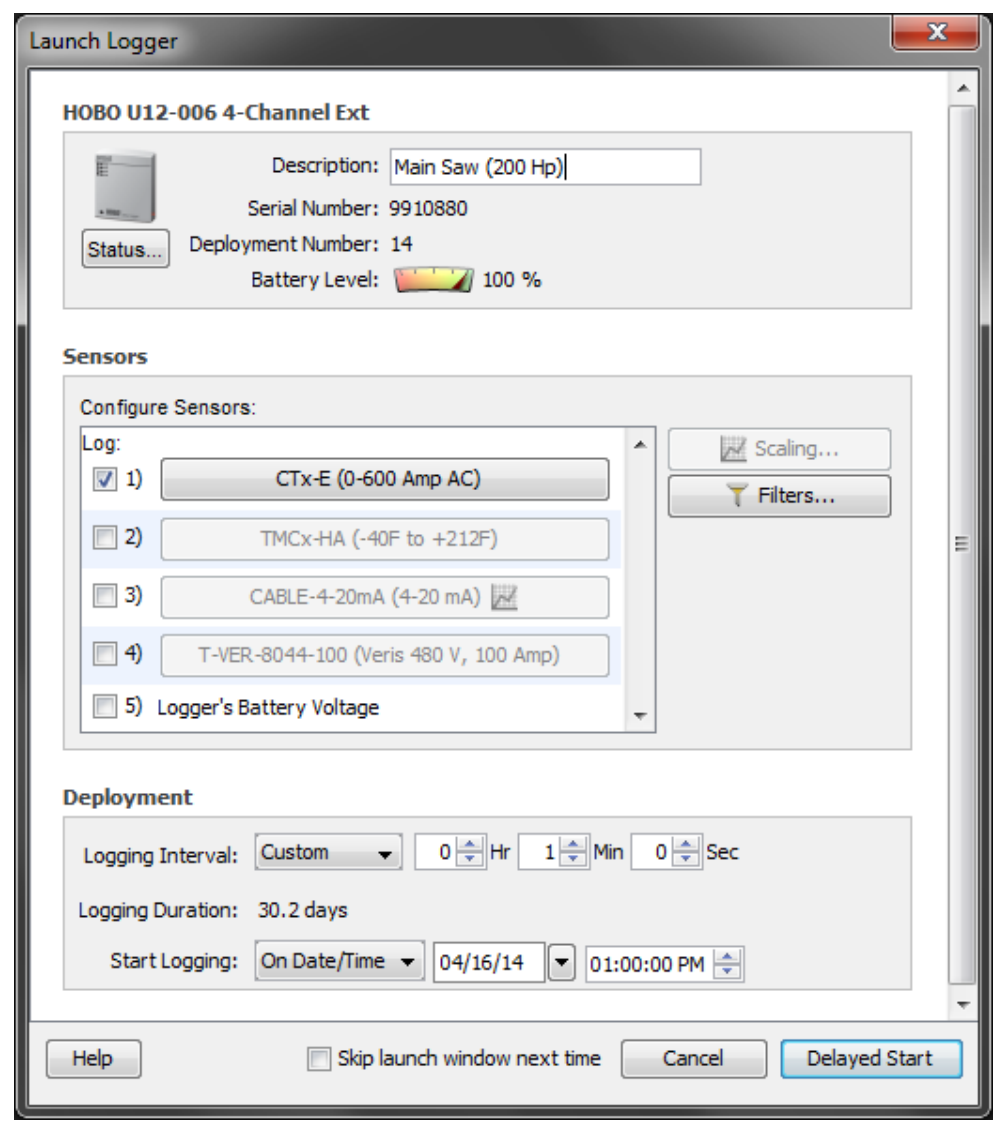

Figure 3.1.7: A Snap Shot of HOBOware Software 


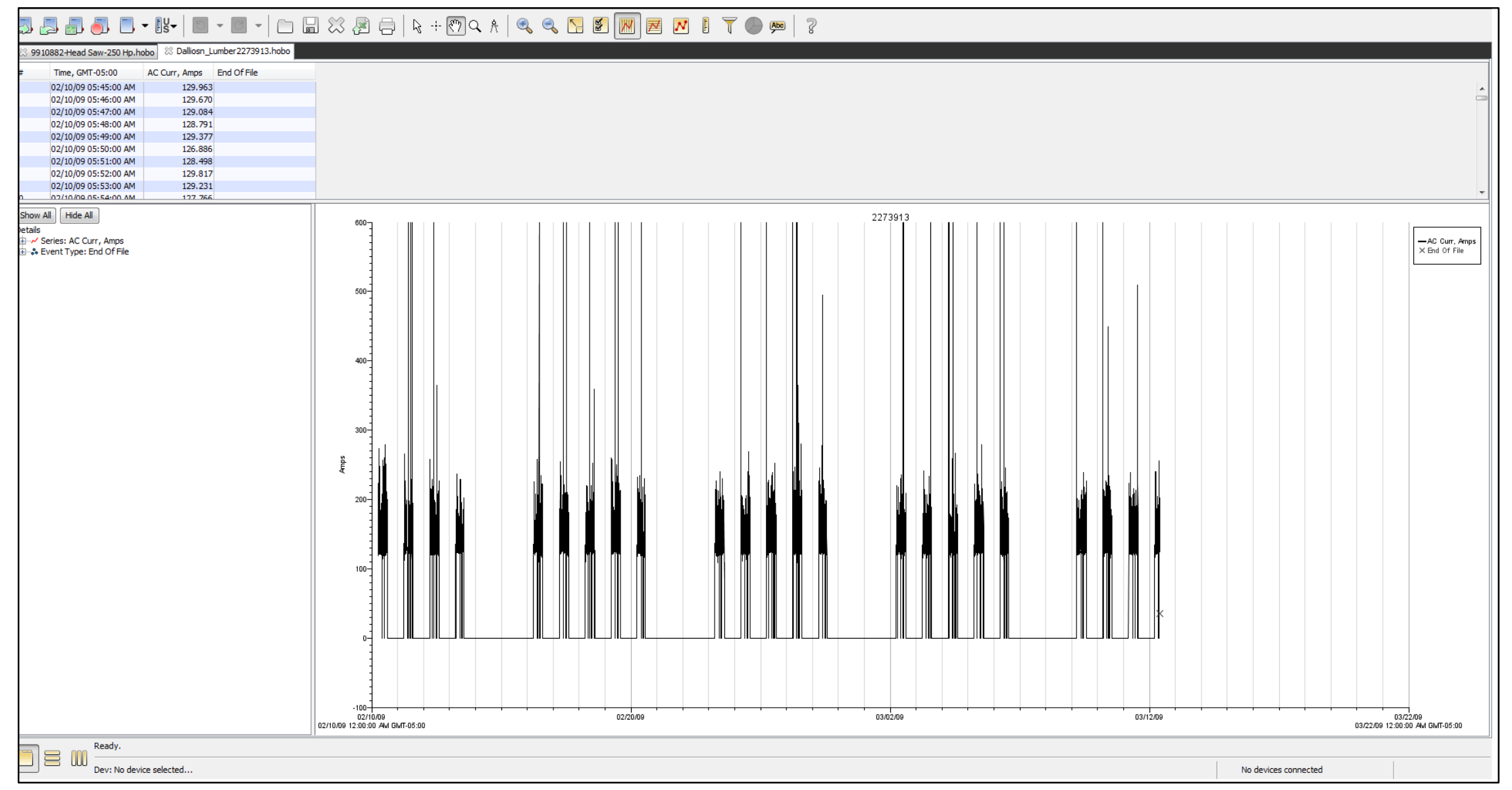

Figure 3.1.8: Graphical Format of Electricity Consumption during Different Dates

Due to a limited number of data loggers, data were not collected on every motor. Only main motors in each sawmill were selected for data collection. The data logged motors with their power factors, voltages, and extra other motors of which data was not collected are shown in Table 3.1.1. 
Table 3.1.1: Electrical Parameters of motors in Sawmills

\begin{tabular}{|c|c|c|c|c|c|c|c|c|c|}
\hline \multirow[b]{2}{*}{ Motor } & \multicolumn{3}{|c|}{ Sawmill 1} & \multicolumn{3}{|c|}{ Sawmill 2} & \multicolumn{3}{|c|}{ Sawmill 3} \\
\hline & $H P$ & $P F^{*}$ & Voltage $^{*}$ & $H P$ & $P F^{*}$ & Voltage* & $H P$ & $P F^{*}$ & Voltage $^{*}$ \\
\hline Main Saw & 200 & 0.41 & 487 & 200 & 0.28 & 470 & 150 & 0.60 & 483 \\
\hline Re-saw & - & - & - & 60 & 0.25 & 478 & 150 & 0.85 & 460 \\
\hline Top Saw & - & - & - & 40 & 0.28 & 470 & - & - & - \\
\hline Edger & 50 & 0.42 & 486 & 50 & 0.27 & 478 & 50 & 0.85 & 460 \\
\hline Trimmer & 25 & 0.37 & 488 & 10 & 0.14 & 477 & 100 & 0.94 & 480 \\
\hline De-barker & 85 & 0.70 & 487 & 50 & 0.60 & 473 & 100 & 0.40 & 480 \\
\hline $\begin{array}{l}\text { De-barker } \\
\text { Hydraulic }\end{array}$ & - & - & - & - & - & - & 30 & 0.30 & 479 \\
\hline Gang saw & - & - & - & - & - & - & 100 & 0.75 & 477 \\
\hline Carriage Motor & 150 & 0.41 & 487 & 100 & 0.38 & 478 & 100 & 0.60 & 483 \\
\hline Compressors & 40 & 0.64 & 485 & 60 & 0.86 & 474 & 300 & 0.60 & 467 \\
\hline Chipper & 150 & 0.42 & 487 & 150 & 0.30 & 494 & 300 & 0.35 & 478 \\
\hline Chip Bin & 30 & 0.48 & 487 & 30 & 0.86 & 474 & - & - & - \\
\hline Dust Collector & 37 & 0.42 & 487 & 15 & 0.81 & 475 & - & - & - \\
\hline Log turner & - & - & - & 40 & 0.47 & 474 & 20 & 0.44 & 483 \\
\hline Conveyor & 15 & 0.48 & 487 & - & - & - & - & - & - \\
\hline Barn Sweep & 5 & 0.48 & 487 & - & - & - & - & - & - \\
\hline Bark hog & - & - & - & - & - & - & - & - & - \\
\hline Log Deck Motor & - & - & - & - & - & - & 20 & 0.76 & 480 \\
\hline Line Bar Hydraulic & - & - & - & - & - & - & 10 & 0.46 & 460 \\
\hline Extra Motors & 30 & - & - & 163 & - & - & 256 & - & - \\
\hline Total & 817 & - & - & 968 & - & - & 1,686 & - & - \\
\hline
\end{tabular}

* Average values 
Average power factor values from data sample of 30 minutes were considered in calculating the total energy consumption of the motors since they represented the actual power factor for the entire data logging period. And also, the energy consumption calculated from using average power factor matched with the actual energy bills. The actual energy consumption from the electricity bills is compared with calculated energy consumption of the motors from the data loggers and are shown in Table 3.1.2.

Table 3.1.2: Energy Consumption from the Data Loggers vs Electricity Bills

\begin{tabular}{|l|c|c|c|c|}
\hline Sawmill & $\begin{array}{c}\text { Production } \\
\text { Hours }\end{array}$ & $\begin{array}{c}\text { Energy Consumption } \\
\text { from Data Loggers } \\
\text { (kWh) }\end{array}$ & $\begin{array}{c}\text { HVAC + } \\
\text { Lighting } \\
\text { (kWh) }\end{array}$ & $\begin{array}{c}\text { Energy Consumption } \\
\text { from Electricity Bills } \\
\text { (kWh) }\end{array}$ \\
\hline Sawmill 1 & 179 & 35,154 & 1,150 & 36,524 \\
\hline Sawmill 2 & 144 & 37,866 & 1,650 & 42,988 \\
\hline Sawmill 3 & 214 & 111,797 & 26,832 & 158,073 \\
\hline
\end{tabular}

The difference between the electricity bills consumption and energy consumption from the data loggers plus HVAC \& lighting accounts for energy consumption of the compressors and other small motors during maintenance period.

\subsection{Collection of Production Data}

A detailed questionnaire was prepared for collecting energy consuming equipment data (electrical motors, HVAC, lighting, and other equipment), production schedule, and process parameters such as wood species, log dimensions, grades, and board feet of the lumber produced. Board foot is the unit used to measure the volume of lumber produced. One board foot lumber is the volume of 1 inch thick board with one foot length and one foot width as shown in Figure 3.2.1.

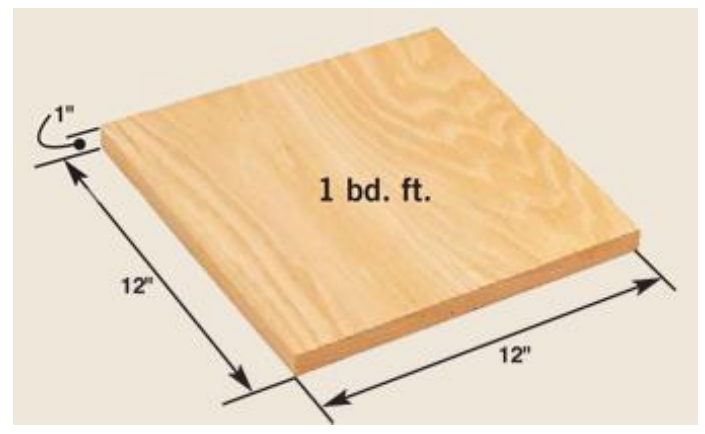

Figure 3.2.1: One Board Foot

The picture of the detailed questionnaire is presented in the Appendix section. Data sheets were provided to sawmill owners to note down wood species, lumber grades, and board feet of the 
lumber produced in each shift. Data sheets as well as data loggers were collected from the sawmills after 30 days. The total board feet of the lumber produced per week in each sawmill is shown in the Table 3.2.1.

Table 3.2.1: Lumber Produced in Sawmills

\begin{tabular}{|c|c|c|c|}
\hline Week & $\begin{array}{c}\text { Sawmill 1 } \\
\text { (Board Feet) }\end{array}$ & $\begin{array}{c}\text { Sawmill 2 } \\
\text { (Board Feet) }\end{array}$ & $\begin{array}{c}\text { Sawmill 3 } \\
\text { (Board Feet) }\end{array}$ \\
\hline 1 & 77,561 & 105,594 & 328,428 \\
\hline 2 & 98,654 & 120,388 & 267,655 \\
\hline 3 & 93,194 & 120,173 & 252,669 \\
\hline 4 & 85,113 & 114,839 & 143,141 \\
\hline 5 & 66,165 & - & - \\
\hline Total & $\mathbf{4 2 0 , 6 8 7}$ & $\mathbf{4 6 0 , 9 9 4}$ & $\mathbf{9 9 1 , 8 9 3}$ \\
\hline
\end{tabular}

Each sawmill produced different sizes and grades of lumber from different wood species. The type of wood species and overall production is shown in Table 3.2.2. All wood species were classified as either hard-hardwood or soft-hardwood based on their densities. Species with density of 60 pounds per cubic foot or more are considered as hard-hardwoods and below 55 are considered as soft-hardwoods. As seen in Table 3.2.2, white oak, red oak, soft maple and hard maple are the most common species that were produced in all the three sawmills.

Table 3.2.2: Type of Wood Species in Sawmills

\begin{tabular}{|c|c|c|c|c|c|c|}
\hline Species & $\begin{array}{c}\text { Density } \\
\left(\mathbf{l b} / \mathbf{f t}^{3}\right)^{*}\end{array}$ & $\begin{array}{l}\text { Species } \\
\text { Group }^{* *}\end{array}$ & $\begin{array}{c}\text { Sawmill } 1 \\
\text { (Board } \\
\text { Feet) }\end{array}$ & $\begin{array}{c}\text { Sawmill } 2 \\
\text { (Board } \\
\text { Feet) }\end{array}$ & $\begin{array}{c}\text { Sawmill } 3 \\
\text { (Board } \\
\text { Feet) }\end{array}$ & $\begin{array}{c}\text { Total } \\
\text { (Board } \\
\text { Feet) }\end{array}$ \\
\hline Hickory & 66 & HHW & 27,578 & 8,681 & - & 36,259 \\
\hline White Oak & 64 & HHW & 107,427 & 89,409 & 183,462 & 380,298 \\
\hline Red Oak & 62 & HHW & 194,264 & 183,480 & 312,510 & 690,254 \\
\hline Hard Maple & 62 & HHW & 23,294 & 60,829 & 130,345 & 214,468 \\
\hline Soft Maple & 55 & HHW & 29,689 & 64,559 & 132,380 & 226,628 \\
\hline Ash & 50 & SHW & - & 13,786 & 36,489 & 50,275 \\
\hline Cherry & 52 & SHW & - & 40,250 & - & 40,250 \\
\hline Poplar & 45 & SHW & 38,435 & - & 196,707 & 235,142 \\
\hline Total & & - & 420,687 & 460,994 & 991,893 & $1,873,574$ \\
\hline
\end{tabular}

Each sawmill produced various grades of lumber with different sizes during each shift. The commercial lumber is graded by some specific rules that make purchasing uniform throughout the 
nation. These grading rules are established by manufacturer's associations. Before 1898, sawmill owners used to grade hardwood lumber in accordance to the local markets. After 1898, the National Hardwood Lumber Association was formed to standardize the grading of hardwood lumber [41]. Grades are established based on the size and number of individual pieces that can be obtained from a board of lumber during cutting process. There are eight lumber grades that are commonly used in today's market. Out of them FAS is the highest grade whereas No.3B common is the lowest grade. Here is a brief description of the common grades.

FAS: The term FAS stands for "First and Seconds" and considered as the highest grade of lumber. The width of FAS lumber is at least 6 inches with a length of 8-16 feet. A number of cuttings on a FAS lumber can be obtained by dividing the surface measure by 4 [42].

F1F: It is also called as FAS 1-Face. The minimum width of F1F lumber is 6 inches.

Selects: The price of this grade lumber is almost same as FAS. The minimum width is 4 inches.

No. 1 Common: This lumber is suitable for making furniture and the minimum width is 3 inches.

No. 2A, 2B, 3A, 3B Common: The letter A represents clear cuttings and letter B represents cuttings are required to free from rot, pith, shake, and wane [42]. 2A and 2B are the standard grades for making cabinets whereas $3 \mathrm{~A}$ and $3 \mathrm{~B}$ are suitable for flooring and pallets [43]. The minimum width of these grades is 3 inches. As explained above, there are no standard widths specified by hardwood lumber grades. However, they specify the minimum width for each grade as shown in Table 3.2.3.

Table 3.2.3: Minimum Width of Different Grades

\begin{tabular}{|c|c|}
\hline Grade & $\begin{array}{c}\text { Minimum Width } \\
\text { (Inches) }\end{array}$ \\
\hline FAS & 6 \\
\hline F1F & 6 \\
\hline Selects & 4 \\
\hline $\begin{array}{c}\text { No.1,2A, 2B, } 3 \text { B Common } \\
\text { 3A,3 }\end{array}$ \\
\hline
\end{tabular}

Apart from these grades, each sawmill produced cants, timbers, and pallet material of different sizes. As thickness is not considered in grading lumber, all thicknesses were combined with respect to their grade while reporting total lumber produced for that grade. The production of each sawmill in terms of grades is shown in Table 3.2.4. 
Table 3.2.4: Breakdown of Lumber Production as per Grades in Sawmills

\begin{tabular}{|l|c|c|c|c|c|c|c|c|}
\hline & $\begin{array}{c}\text { FAS } \\
\text { (Board Feet) }\end{array}$ & $\begin{array}{c}\text { F1F } \\
\text { (Board Feet) }\end{array}$ & $\begin{array}{c}\text { 1COM } \\
\text { (Board Feet) }\end{array}$ & $\begin{array}{c}\text { 2COM } \\
\text { (Board Feet) }\end{array}$ & $\begin{array}{c}\text { 3COM } \\
\text { (Board } \\
\text { Feet) }\end{array}$ & $\begin{array}{c}\text { Pallet } \\
\text { Material } \\
\text { (Board Feet) }\end{array}$ & $\begin{array}{c}\text { Cants } \\
\text { (Board Feet) }\end{array}$ & $\begin{array}{c}\text { Timbers } \\
\text { (Board Feet) }\end{array}$ \\
\hline Sawmill 1 & 26,371 & 16,279 & 61,769 & 75,870 & 30,223 & 14,666 & 79,812 & 115,697 \\
\hline Sawmill 2 & - & 135,953 & 65,532 & 95,442 & 71,779 & 64,850 & 17,403 & 10,035 \\
\hline Sawmill 3 & 179,134 & 103,404 & 248,689 & 262,660 & 45,900 & 58,791 & 68,283 & 25,032 \\
\hline
\end{tabular}

Each sawmill was producing lumber with different thicknesses. The lumber production as per thickness is shown in Table 3.2.5. Pallet materials, cants, and timbers have different sizes in each sawmill and are shown in Table 3.2.6. Lumber thickness is measured in quarters of an inch. For example one inch thickness is called as 4 quarter and identified as $4 / 4$ ”.

Table 3.2.5: Breakdown of Lumber Production as per Thickness in Sawmills

\begin{tabular}{|c|c|c|c|c|}
\hline & $\begin{array}{c}\text { 4/4” } \\
\text { (Board Feet) }\end{array}$ & $\begin{array}{c}\mathbf{5 / 4} \text { (Board Feet) } \\
\text { (Board Feet) }\end{array}$ & $\begin{array}{c}\mathbf{8} / 4 \text { '” } \\
\text { (Board Feet) }\end{array}$ \\
\hline Sawmill 1 & 158,100 & 25,866 & 12,284 & 14,262 \\
\hline Sawmill 2 & 327,363 & 23,905 & 7,618 & 9,820 \\
\hline Sawmill 3 & 607,941 & 197,817 & - & 34,029 \\
\hline
\end{tabular}

Table 3.2.5: Sizes of Pallets, Cants, and Timbers in Each Sawmill

\begin{tabular}{|l|c|c|c|c|c|c|c|c|c|}
\hline & \multicolumn{3}{|c|}{ Pallet Material } & \multicolumn{4}{c|}{ Cants } & \multicolumn{3}{c|}{ Timbers } \\
\hline & Length & Width & Thickness & Length & Width & Thickness & Length & Width & Thickness \\
\hline Sawmill 1 & $10 \mathrm{ft}$ & $6 \sim 12 \mathrm{inch}$ & $1 \mathrm{inch}$ & $12 \mathrm{ft}$ & $4 \sim 12 \mathrm{inch}$ & $\begin{array}{c}3 \text { inch, 3.5 inch, } \\
5 \mathrm{inch}\end{array}$ & $10 \mathrm{ft}$ & $9 \mathrm{inch}$ & $7 \mathrm{inch}$ \\
\hline Sawmill 2 & $10 \mathrm{ft}$ & $6 \sim 12 \mathrm{inch}$ & $1 \mathrm{inch}$ & $12 \mathrm{ft}$ & $4 \sim 12 \mathrm{inch}$ & $3 \mathrm{inch}$ & $8.5 \mathrm{ft}$ & $9 \mathrm{inch}$ & $7 \mathrm{inch}$ \\
\hline Sawmill 3 & $10 \mathrm{ft}$ & $6 \sim 12 \mathrm{inch}$ & $1 \mathrm{inch}$ & $12 \mathrm{ft}$ & $4 \sim 12 \mathrm{inch}$ & $3.5 \mathrm{inch}$ & $10 \mathrm{ft}$ & $9 \mathrm{inch}$ & $7 \mathrm{inch}$ \\
\hline
\end{tabular}




\subsection{Data Collection on Productivity from Logs}

To understand log volumes and sawing relationships, data collected by the Appalachian Hardwood Center at West Virginia University were referenced in this study. These data includes dimensions of logs sawn, board feet of lumber produced, and wastage of log due to defects and sawing. From these data, the percentage of lumber volume in a log is approximately estimated. The log volume in board feet is calculated based on Doyle log scale. This rule is most commonly used by timber industry in West Virginia. The main problem of Doyle's log scale is it often underestimates the board feet of lumber produced from small logs and overestimates the yield from the bigger logs. The extra yield that is more than the predicted board feet of lumber from the log is called as over run. The formula to estimate the log volume by using the Doyle rule is,

$$
\text { Log Volume (Board Feet) }=\frac{(\mathrm{D}-4)^{2} \times \mathrm{L}}{16}
$$

Where,

$$
\begin{aligned}
& \mathrm{D} \quad=\text { Log diameter inside the bark at the small end, inches } \\
& \mathrm{L} \quad=\text { Log length, feet }
\end{aligned}
$$

The length of the log is the last full foot and should not be rounded up to the next foot. The excess length is considered as trim. For example, 10 feet 10 inches of log length is considered as 10 feet length $\log$ with $10 \mathrm{inch}$ trim. Logs used to produce lumber are classified as factory logs and graded based on the number of clear faces on it without defects. High quality factory logs will have four clear faces and produce maximum proportion of high grade lumber [45]. In this analysis, logs with four clear faces are considered as high grade factory logs, logs with two and three clear faces are considered as medium grade, and logs with one clear face are considered as low grade logs. The average percentages of high grade lumber and low grade lumber produced from three different log grades were calculated. The high grade lumber includes FAS, FIF, Select grades and low grade lumber includes No.1, 2A, 2B, 3A, 3B common grades. Table 3.3.1 shows the amount of different grade lumber produced from different grade logs of 16 feet length. 
Table 3.3.1: Lumber Produced from Different Grade Logs

\begin{tabular}{|c|c|c|c|c|c|c|c|c|c|c|}
\hline \multicolumn{11}{|c|}{ High Grade Logs } \\
\hline $\begin{array}{c}\text { Diameter } \\
\text { (Inches) }\end{array}$ & $\begin{array}{c}\text { Length } \\
\text { (Feet) }\end{array}$ & $\begin{array}{c}\text { Trim } \\
\text { (Inches) }\end{array}$ & $\begin{array}{l}\text { No. of } \\
\text { Clear } \\
\text { faces }\end{array}$ & $\begin{array}{c}\text { Doyle's } \\
\text { Volume } \\
\text { (Board } \\
\text { Feet) }\end{array}$ & \begin{tabular}{|c|} 
Total \\
Lumber \\
Produced \\
(Board \\
Feet) \\
\end{tabular} & $\begin{array}{c}\text { Over } \\
\text { Run } \\
\text { (Board } \\
\text { Feet) }\end{array}$ & $\begin{array}{c}\text { High } \\
\text { Grade } \\
\text { Lumber } \\
\text { (Board } \\
\text { Feet) } \\
\end{array}$ & $\begin{array}{c}\text { Low } \\
\text { Grade } \\
\text { Lumber } \\
\text { (Board } \\
\text { Feet) } \\
\end{array}$ & $\begin{array}{c}\text { Cants + } \\
\text { Timbers } \\
\text { (Board } \\
\text { Feet) }\end{array}$ & $\begin{array}{c}\text { Defects } \\
\text { (Board } \\
\text { Feet) }\end{array}$ \\
\hline 28 & 16 & 5 & 4 & 576 & 529 & -47 & 415 & 114 & 0 & 0 \\
\hline 22 & 16 & 3 & 4 & 324 & 299 & -25 & 260 & 39 & 0 & 0 \\
\hline 18 & 16 & 7 & 4 & 196 & 213 & 17 & 146 & 67 & 0 & 0 \\
\hline 18 & 16 & 10 & 4 & 196 & 235 & 39 & 160 & 27 & 36 & 12 \\
\hline 17 & 16 & 6 & 4 & 169 & 189 & 20 & 153 & 36 & 0 & 0 \\
\hline 17 & 16 & 7 & 4 & 169 & 185 & 16 & 108 & 67 & 5 & 0 \\
\hline 16 & 16 & 8 & 4 & 144 & 183 & 39 & 122 & 26 & 28 & 7 \\
\hline 16 & 16 & 5 & 4 & 144 & 173 & 29 & 92 & 66 & 10 & 5 \\
\hline 15 & 16 & 8 & 4 & 121 & 123 & 2 & 62 & 51 & 10 & 0 \\
\hline 14 & 16 & 7 & 4 & 100 & 116 & 16 & 61 & 55 & 0 & 0 \\
\hline 14 & 16 & 6 & 4 & 100 & 111 & 11 & 42 & 69 & 0 & 0 \\
\hline \multicolumn{11}{|c|}{ Medium Grade Logs } \\
\hline 24 & 16 & 2 & 3 & 400 & 391 & -9 & 187 & 204 & 0 & 0 \\
\hline 20 & 16 & 8 & 3 & 256 & 252 & -4 & 125 & 127 & 0 & 0 \\
\hline 18 & 16 & 5 & 3 & 196 & 196 & 0 & 11 & 185 & 0 & 0 \\
\hline 16 & 16 & 7 & 3 & 144 & 168 & 24 & 82 & 86 & 0 & 0 \\
\hline 15 & 16 & 8 & 3 & 121 & 146 & 25 & 77 & 69 & 0 & 0 \\
\hline 15 & 16 & 8 & 3 & 121 & 132 & 11 & 47 & 85 & 0 & 0 \\
\hline 14 & 16 & 5 & 3 & 100 & 106 & 6 & 42 & 64 & 0 & 0 \\
\hline 14 & 16 & 3 & 3 & 100 & 120 & 20 & 44 & 76 & 0 & 0 \\
\hline 10 & 16 & 2 & 3 & 36 & 46.5 & 10.5 & 0 & 8 & 25 & 14 \\
\hline
\end{tabular}


Table 3.3.1: Lumber Produced from Different Grade Logs (Cont.)

\begin{tabular}{|c|c|c|c|c|c|c|c|c|c|c|}
\hline \multicolumn{11}{|c|}{ Medium Grade Logs } \\
\hline $\begin{array}{c}\text { Diameter } \\
\text { (Inches) }\end{array}$ & $\begin{array}{c}\text { Length } \\
\text { (Feet) }\end{array}$ & $\begin{array}{c}\text { Trim } \\
\text { (Inches) }\end{array}$ & $\begin{array}{l}\text { No. of } \\
\text { Clear } \\
\text { faces }\end{array}$ & $\begin{array}{c}\text { Doyle's } \\
\text { Volume } \\
\text { (Board } \\
\text { Feet) }\end{array}$ & \begin{tabular}{|c|} 
Total \\
Lumber \\
Produced \\
(Board \\
Feet) \\
\end{tabular} & $\begin{array}{c}\text { Over } \\
\text { Run } \\
\text { (Board } \\
\text { Feet) }\end{array}$ & $\begin{array}{c}\text { High } \\
\text { Grade } \\
\text { Lumber } \\
\text { (Board } \\
\text { Feet) }\end{array}$ & $\begin{array}{c}\text { Low } \\
\text { Grade } \\
\text { Lumber } \\
\text { (Board } \\
\text { Feet) }\end{array}$ & $\begin{array}{c}\text { Cants + } \\
\text { Timbers } \\
\text { (Board } \\
\text { Feet) }\end{array}$ & $\begin{array}{c}\text { Defects } \\
\text { (Board } \\
\text { Feet) }\end{array}$ \\
\hline 18 & 16 & 4 & 2 & 196 & 199 & 3 & 0 & 115 & 60 & 24 \\
\hline 15 & 16 & 7 & 2 & 121 & 135 & 14 & 25 & 110 & 0 & 0 \\
\hline 15 & 16 & 8 & 2 & 121 & 158 & 37 & 22 & 136 & 0 & 0 \\
\hline 14 & 16 & 10 & 2 & 100 & 128 & 28 & 26 & 77 & 13 & 12 \\
\hline 13 & 16 & 9 & 2 & 81 & 103 & 22 & 18 & 45 & 27 & 13 \\
\hline \multicolumn{11}{|c|}{ Low Grade Logs } \\
\hline 20 & 16 & 7 & 1 & 256 & 228 & -28 & 0 & 154 & 58 & 16 \\
\hline 16 & 16 & 5 & 1 & 144 & 170 & 26 & 20 & 66 & 63 & 21 \\
\hline 16 & 16 & 9 & 1 & 144 & 172 & 28 & 15 & 157 & 0 & 0 \\
\hline 14 & 16 & 8 & 1 & 100 & 130 & 30 & 0 & 94 & 20 & 16 \\
\hline 13 & 16 & 9 & 1 & 81 & 101 & 20 & 8 & 93 & 0 & 0 \\
\hline
\end{tabular}


Table 3.3.2: Percentages of Lumber Produced from Different Grade Logs

\begin{tabular}{|c|c|c|c|c|c|c|c|c|}
\hline \multicolumn{9}{|c|}{ High Grade Logs } \\
\hline $\begin{array}{c}\text { Diameter } \\
\text { (Inches) }\end{array}$ & $\begin{array}{l}\text { Length } \\
\text { (Feet) }\end{array}$ & $\begin{array}{c}\text { Trim } \\
\text { (Inches) }\end{array}$ & $\begin{array}{l}\text { No. of } \\
\text { Clear } \\
\text { faces }\end{array}$ & \begin{tabular}{|c|} 
Total \\
Lumber \\
Produced \\
(Board \\
Feet) \\
\end{tabular} & $\begin{array}{c}\text { High } \\
\text { Grade } \\
\text { Lumber } \\
(\%)\end{array}$ & $\begin{array}{c}\text { Low } \\
\text { Grade } \\
\text { Lumber } \\
(\%)\end{array}$ & $\begin{array}{c}\text { Cants + } \\
\text { Timbers } \\
(\%)\end{array}$ & $\begin{array}{c}\text { Defects } \\
(\%)\end{array}$ \\
\hline 28 & 16 & 5 & 4 & 529 & 0.78 & 0.22 & 0.00 & 0.00 \\
\hline 22 & 16 & 3 & 4 & 299 & 0.87 & 0.13 & 0.00 & 0.00 \\
\hline 18 & 16 & 7 & 4 & 213 & 0.69 & 0.31 & 0.00 & 0.00 \\
\hline 18 & 16 & 10 & 4 & 235 & 0.68 & 0.11 & 0.15 & 0.05 \\
\hline 17 & 16 & 6 & 4 & 189 & 0.81 & 0.19 & 0.00 & 0.00 \\
\hline 17 & 16 & 7 & 4 & 180 & 0.60 & 0.37 & 0.03 & 0.00 \\
\hline 16 & 16 & 8 & 4 & 183 & 0.67 & 0.14 & 0.15 & 0.04 \\
\hline 16 & 16 & 5 & 4 & 173 & 0.53 & 0.38 & 0.06 & 0.03 \\
\hline 15 & 16 & 8 & 4 & 123 & 0.50 & 0.41 & 0.08 & 0.00 \\
\hline 14 & 16 & 7 & 4 & 116 & 0.53 & 0.47 & 0.00 & 0.00 \\
\hline 14 & 16 & 6 & 4 & 111 & 0.38 & 0.62 & 0.00 & 0.00 \\
\hline \multicolumn{5}{|c|}{ Average } & 0.64 & 0.31 & 0.04 & 0.01 \\
\hline \multicolumn{9}{|c|}{ Medium Grade Logs } \\
\hline 24 & 16 & 2 & 3 & 391 & 0.48 & 0.52 & 0.00 & 0.00 \\
\hline 20 & 16 & 8 & 3 & 252 & 0.50 & 0.50 & 0.00 & 0.00 \\
\hline 18 & 16 & 5 & 3 & 196 & 0.06 & 0.94 & 0.00 & 0.00 \\
\hline 16 & 16 & 7 & 3 & 168 & 0.49 & 0.51 & 0.00 & 0.00 \\
\hline 15 & 16 & 8 & 3 & 146 & 0.53 & 0.47 & 0.00 & 0.00 \\
\hline 15 & 16 & 8 & 3 & 132 & 0.36 & 0.64 & 0.00 & 0.00 \\
\hline 14 & 16 & 5 & 3 & 106 & 0.40 & 0.60 & 0.00 & 0.00 \\
\hline
\end{tabular}


Table 3.3.2: Percentages of Lumber Produced from Different Grade Logs (Cont.)

\begin{tabular}{|c|c|c|c|c|c|c|c|c|}
\hline 14 & 16 & 3 & 3 & 120 & 0.37 & 0.63 & 0.00 & 0.00 \\
\hline 10 & 16 & 2 & 3 & 46.5 & 0.00 & 0.17 & 0.54 & 0.29 \\
\hline 22 & 16 & 5 & 2 & 309 & 0.22 & 0.78 & 0.30 & 0.12 \\
\hline 18 & 16 & 4 & 2 & 199 & 0.00 & 0.58 & 0.00 & 0.00 \\
\hline 15 & 16 & 7 & 2 & 135 & 0.19 & 0.81 & 0.00 & 0.00 \\
\hline 15 & 16 & 8 & 2 & 158 & 0.14 & 0.86 & 0.10 & 0.09 \\
\hline 14 & 16 & 10 & 2 & 128 & 0.20 & 0.60 & 0.26 & 0.13 \\
\hline 13 & 16 & 9 & 2 & 103 & 0.17 & 0.44 & 0.30 & 0.12 \\
\hline \multicolumn{5}{|c|}{ Average } & 0.28 & 0.61 & 0.07 & 0.04 \\
\hline \multicolumn{9}{|c|}{ Low Grade Logs } \\
\hline 20 & 16 & 7 & 1 & 228 & 0 & 0.68 & 0.25 & 0.08 \\
\hline 16 & 16 & 5 & 1 & 170 & 0.12 & 0.39 & 0.37 & 0.13 \\
\hline 16 & 16 & 9 & 1 & 172 & 0.09 & 0.91 & 0.00 & 0.00 \\
\hline 14 & 16 & 8 & 1 & 130 & 0 & 0.72 & 0.15 & 0.12 \\
\hline 13 & 16 & 9 & 1 & 101 & 0.08 & 0.92 & 0.00 & 0.00 \\
\hline \multicolumn{5}{|c|}{ Average } & 0.06 & 0.71 & 0.15 & 0.08 \\
\hline
\end{tabular}

As shown in Table 3.3.2, high grade logs yields maximum proportion of high quality lumber. The proportions of lumber from different grade logs are considered in the cost and energy analysis in Chapter 4 . To be conservative, percentages were rounded to the closest multiple of 5 as shown in Table 3.3.3.

Table 3.3.3: Average Percentages of Lumber Produced from Different Grade Logs

\begin{tabular}{|c|c|c|c|c|}
\hline Logs & $\begin{array}{c}\text { High Grade } \\
\text { Lumber (\%) }\end{array}$ & $\begin{array}{c}\text { Low Grade } \\
\text { Lumber (\%) }\end{array}$ & $\begin{array}{c}\text { Cants + } \\
\text { Timbers (\%) }\end{array}$ & Defects (\%) \\
\hline High Grade & 65 & 30 & 4 & 1 \\
\hline Medium Grade & 30 & 60 & 5 & 5 \\
\hline Low Grade & 5 & 70 & 15 & 10 \\
\hline
\end{tabular}




\subsection{Energy Consumption of Motors}

The electricity consumption of motors can be calculated in two ways. Two methods with examples are explained below.

1) The three phase input power $(\mathrm{kW})$ of the motors when parameters measured by data loggers and hand held equipment are available can be calculated by,

$$
\mathrm{kW}=\frac{\sqrt{3} \mathrm{xVxIx} \cos \varphi}{1000}
$$

Where, $\quad \mathrm{kW} \quad=$ Power consumption in $\mathrm{kW}$

$$
\begin{array}{ll}
\mathrm{V} & =\text { Voltage } \\
\mathrm{I} & =\text { Amperage } \\
\operatorname{Cos} \varphi & =\text { Power Factor }
\end{array}
$$

This method is used for data logged motors. As an example, power consumed by the main saw (200 hp) in Sawmill 1 during $1^{\text {st }}$ shift can be calculated as follows:

$$
\begin{array}{ll}
\text { Amperage } & =143.44 \\
\text { Voltage } & =487.45
\end{array}
$$

Average power factor $=0.41$

$$
\begin{aligned}
\mathrm{kW} & =1.732 \times 487.45 \times 143.44 \times 0.41 / 1000 \\
& =49.65 \mathrm{~kW}
\end{aligned}
$$

The total energy consumed ( $\mathrm{kWh}$ ) by main saw during $1^{\text {st }}$ shift (4.63 hours) is calculated as;

$$
\begin{aligned}
\mathrm{kWh} & =\mathrm{kW} \times \text { Operating hours } \\
& =49.65 \mathrm{~kW} \times 4.63 \text { hours } \\
& =229.88 \mathrm{kWh}
\end{aligned}
$$

2) When input parameters are unknown, the energy consumption (kWh) of the motor can be calculated by using its horsepower as follows:

$$
\mathrm{kWh}=\frac{\mathrm{HP} \times 0.746 \mathrm{~kW} / \mathrm{hp} \times \mathrm{LF} \times \mathrm{OH}}{\mathrm{EFF}}
$$




Where, $\quad \begin{array}{ll}\mathrm{kWh} & =\text { Estimated energy used in } \mathrm{kWh} / \mathrm{yr} \\ \mathrm{HP} & =\text { Horsepower of the motor } \\ \mathrm{LF} & =\text { Load factor } \\ \mathrm{OH} & =\text { Operating hours } \\ \mathrm{EFF} & =\text { Motor efficiency }\end{array}$

This method is used for extra motors for which data were not collected. The average of load factors of all data collected motors during each shift was considered for extra motors. Load factors of all the motors in each sawmill are shown in the Appendix. The average load factor of extra motors during each shift are shown in Table 3.4.1. The efficiency of the extra motors in the sawmills is estimated as $80 \%$.

The load factor of a motor can be defined as the "ratio of measured three phase power $(\mathrm{kW})$ to actual power at full rated load (kW)". As an example, load factor of the main saw (200 hp) in Sawmill 1 during 1st shift can be calculated as follows:

$\begin{array}{ll}\text { Measured power }(\mathrm{kW}) & =49.22 \mathrm{~kW} \\ \text { Actual power }(\mathrm{kW}) & =200 \mathrm{hp} \times 0.746 \mathrm{~kW} / \mathrm{hp}=149 \mathrm{~kW} \\ \text { Load factor } & =49.22 \mathrm{~kW} / 149 \mathrm{~kW} \\ & =0.33 \text { or } 33 \%\end{array}$

As an example, energy consumed by the extra motors in Sawmill 2 during $1^{\text {st }}$ shift can be calculated as follows:

An average of load factors of the data logged motors during $1^{\text {st }}$ shift was 0.452 and working hours were 9.25 hours. The efficiency of extra motors is considered as $80 \%$.

$$
\begin{aligned}
\mathrm{kWh} & =163 \mathrm{hp} \times 0.746 \mathrm{~kW} / \mathrm{hp} \times 0.452 \times 8.42 / 0.80 \\
& =636 \mathrm{kWh}
\end{aligned}
$$

In a similar way, energy consumption of extra motors in the Sawmill 2 and Sawmill 3 were calculated based on the average of data logged motors' load factors in the respective shift, and working hours in that shift. Sawmill 1 has extra motors of $30 \mathrm{hp}$ capacity. As per discussions with the plant personnel, these motors were rarely used and hence were excluded from the analysis. 
Table 3.4.1: Load Factors (LF) of Extra Motors

\begin{tabular}{|c|c|c|}
\hline Shift & $\begin{array}{c}\text { LF of Extra Motors } \\
\text { in Sawmill } 2 \\
(\%)\end{array}$ & $\begin{array}{c}\text { LF of Extra Motors } \\
\text { in Sawmill } 3 \\
(\%)\end{array}$ \\
\hline 1 & 0.452 & 0.503 \\
\hline 2 & 0.477 & 0.501 \\
\hline 3 & 0.458 & 0.502 \\
\hline 4 & 0.456 & 0.498 \\
\hline 5 & 0.446 & 0.494 \\
\hline 6 & 0.446 & 0.499 \\
\hline 7 & 0.459 & 0.500 \\
\hline 8 & 0.456 & 0.498 \\
\hline 9 & 0.466 & 0.505 \\
\hline 10 & 0.464 & 0.499 \\
\hline 11 & 0.454 & 0.502 \\
\hline 12 & 0.444 & 0.498 \\
\hline 13 & 0.449 & 0.509 \\
\hline 14 & 0.444 & 0.504 \\
\hline 15 & 0.451 & 0.500 \\
\hline 16 & 0.449 & 0.498 \\
\hline 17 & 0.438 & 0.494 \\
\hline 18 & 0.444 & 0.493 \\
\hline 19 & 0.449 & 0.496 \\
\hline 20 & 0.444 & 0.497 \\
\hline 21 & 0.445 & 0.499 \\
\hline 22 & 0.445 & 0.500 \\
\hline 23 & - & 0.498 \\
\hline 24 & - & 0.493 \\
\hline 25 & - & 0.465 \\
\hline 26 & - & 0.505 \\
\hline 27 & - & 0.504 \\
\hline 28 & - & 0.505 \\
\hline 29 & - & 0.503 \\
\hline
\end{tabular}




\subsection{Energy Allocation}

During lumber production, only the head saw, re-saw, edger, and trimmer motors are directly involved in sawing operation whereas other motors are involved in process support. Production data and amperage data were collected for each production shift over a period of one month. During each shift, different sizes of the lumber were produced. The lumber production and energy consumption during each shift of sawmills are shown in Table 3.5.1, Table 3.5.2, and Table 3.5.3.

Table 3.5.1: Lumber Production and Energy Consumption during Each Shift in Sawmill 1

\begin{tabular}{|c|c|c|c|c|c|c|c|c|}
\hline Shift & $\begin{array}{l}\text { 4/4"' } \\
\text { (Board } \\
\text { Feet) }\end{array}$ & $\begin{array}{c}5 / 4 " \\
\text { (Board } \\
\text { Feet) }\end{array}$ & $\begin{array}{c}6 / 4 " \\
\text { (Board } \\
\text { Feet) }\end{array}$ & $\begin{array}{c}\text { 8/4' } \\
\text { (Board } \\
\text { Feet) }\end{array}$ & $\begin{array}{c}\text { Pallet } \\
\text { Material } \\
\text { (Board } \\
\text { Feet) }\end{array}$ & $\begin{array}{c}\text { Cants } \\
\text { (Board Feet) }\end{array}$ & $\begin{array}{c}\text { Timbers } \\
\text { (Board Feet) }\end{array}$ & $\begin{array}{c}\text { Energy } \\
\text { Consumption } \\
(\mathbf{k W h})\end{array}$ \\
\hline 1 & 4,652 & 0 & 0 & 0 & 252 & 2470 & 2767 & 903.83 \\
\hline 2 & 3,783 & 0 & 1792 & 0 & 288 & 2155 & 1770 & 724.24 \\
\hline 3 & 7,819 & 0 & 1748 & 0 & 734 & 4070 & 2470 & $1,535.14$ \\
\hline 4 & 10,190 & 0 & 288 & 0 & 556 & 5080 & 3811 & $1,583.44$ \\
\hline 5 & 3,479 & 0 & 0 & 0 & 496 & 1885 & 1982 & 596.00 \\
\hline 6 & 0 & 0 & 5858 & 0 & 0 & 6852 & 314 & 749.42 \\
\hline 7 & 0 & 0 & 2598 & 0 & 0 & 3994 & 200 & 415.98 \\
\hline 8 & 6,689 & 0 & 0 & 1074 & 204 & 6660 & 3992 & $1,131.87$ \\
\hline 9 & 8,761 & 0 & 0 & 760 & 3960 & 5210 & 3740 & $1,571.08$ \\
\hline 10 & 7,044 & 0 & 0 & 786 & 332 & 5450 & 2390 & $1,504.34$ \\
\hline 11 & 8,979 & 0 & 0 & 1138 & 348 & 4993 & 2600 & $1,537.66$ \\
\hline 12 & 5,783 & 0 & 0 & 1144 & 284 & 3074 & 1840 & 979.90 \\
\hline 13 & 1,808 & 0 & 0 & 0 & 44 & 675 & 2100 & 435.17 \\
\hline 14 & 5,448 & 0 & 0 & 0 & 258 & 1580 & 5524 & $1,115.42$ \\
\hline 15 & 2,731 & 0 & 0 & 392 & 108 & 825 & 2482 & 501.04 \\
\hline 16 & 8,068 & 0 & 0 & 610 & 518 & 2515 & 6416 & $1,604.75$ \\
\hline 17 & 7,882 & 0 & 0 & 1506 & 414 & 3945 & 4364 & $1,531.05$ \\
\hline
\end{tabular}


Table 3.5.1: Lumber Production and Energy Consumption during Each Shift in Sawmill 1 (Cont.)

\begin{tabular}{|c|c|c|c|c|c|c|c|c|}
\hline Shift & $\begin{array}{c}\mathbf{4 / 4} \\
\text { (Board } \\
\text { Feet) }\end{array}$ & $\begin{array}{c}\mathbf{5 / 4} \text { (Board } \\
\text { Feet) }\end{array}$ & $\begin{array}{c}\mathbf{6 / 4} \text { (Board } \\
\text { Feet) }\end{array}$ & $\begin{array}{c}\mathbf{8 / 4} \text { ” } \\
\text { (Board } \\
\text { Feet) }\end{array}$ & $\begin{array}{c}\text { Pallet } \\
\text { Material } \\
\text { (Board } \\
\text { Feet) }\end{array}$ & $\begin{array}{c}\text { Cants } \\
\text { (Board Feet) }\end{array}$ & $\begin{array}{c}\text { Timbers } \\
\text { (Board } \\
\text { Feet) }\end{array}$ & $\begin{array}{c}\text { Energy } \\
\text { Consumption } \\
\text { (kWh) }\end{array}$ \\
\hline 18 & 8,821 & 0 & 0 & 380 & 564 & 2945 & 3254 & $1,458.31$ \\
\hline 19 & 534 & 69 & 0 & 0 & 10 & 0 & 862 & 101.60 \\
\hline 20 & 6,795 & 1488 & 0 & 0 & 330 & 1140 & 10416 & $1,396.76$ \\
\hline 21 & 466 & 1188 & 0 & 0 & 28 & 185 & 1415 & 353.10 \\
\hline 22 & 0 & 6251 & 0 & 0 & 344 & 2510 & 4951 & $1,208.05$ \\
\hline 23 & 0 & 6310 & 0 & 0 & 562 & 3650 & 3527 & $1,422.61$ \\
\hline 24 & 0 & 692 & 0 & 540 & 4 & 240 & 651 & 174.33 \\
\hline 25 & 0 & 6183 & 0 & 3918 & 488 & 3235 & 3695 & $1,529.56$ \\
\hline 26 & 0 & 3685 & 0 & 2014 & 456 & 3235 & 653 & 808.40 \\
\hline 27 & 5,142 & 0 & 0 & 0 & 178 & 1515 & 1475 & 720.68 \\
\hline 28 & 8,507 & 0 & 0 & 0 & 628 & 1991 & 4601 & $1,285.07$ \\
\hline 29 & 6,395 & 0 & 0 & 0 & 452 & 764 & 4303 & $1,049.50$ \\
\hline 30 & 4,261 & 0 & 0 & 0 & 100 & 322 & 1198 & 518.39 \\
\hline 31 & 10,666 & 0 & 0 & 0 & 234 & 854 & 3494 & $1,526.90$ \\
\hline 32 & 729 & 0 & 0 & 0 & 6 & 39 & 1391 & 172.41 \\
\hline 33 & 1,786 & 0 & 0 & 0 & 798 & 1100 & 7278 & $1,371.06$ \\
\hline 34 & 1,369 & 0 & 0 & 0 & 82 & 14 & 1445 & 261.08 \\
\hline 35 & 9,513 & 0 & 0 & 0 & 606 & 1327 & 5639 & $1,375.53$ \\
\hline Total & $\mathbf{1 5 8 , 1 0 0}$ & $\mathbf{2 5 , 8 6 6}$ & $\mathbf{1 2 , 2 8 4}$ & $\mathbf{1 4 , 2 6 2}$ & $\mathbf{1 4 , 6 6 6}$ & $\mathbf{8 6 , 4 9 9}$ & $\mathbf{1 0 9 , 0 1 0}$ & $\mathbf{3 5 , 1 5 4}$ \\
\hline
\end{tabular}


Table 3.5.2: Lumber Production and Energy Consumption during Each Shift in Sawmill 2

\begin{tabular}{|c|c|c|c|c|c|c|c|c|}
\hline Shift & $\begin{array}{c}\text { 4/4"' } \\
\text { (Board } \\
\text { Feet) }\end{array}$ & $\begin{array}{c}5 / 4 " \\
\text { (Board } \\
\text { Feet) }\end{array}$ & $\begin{array}{c}6 / 4 " \\
\text { (Board } \\
\text { Feet) }\end{array}$ & $\begin{array}{c}\text { 8/4"' } \\
\text { (Board } \\
\text { Feet) }\end{array}$ & $\begin{array}{c}\text { Pallet } \\
\text { Material } \\
\text { (Board } \\
\text { Feet) }\end{array}$ & $\begin{array}{c}\text { Cants } \\
\text { (Board } \\
\text { Feet) }\end{array}$ & $\begin{array}{c}\text { Timbers } \\
\text { (Board } \\
\text { Feet) }\end{array}$ & $\begin{array}{c}\text { Energy } \\
\text { Consumption } \\
(\mathbf{k W h})\end{array}$ \\
\hline 1 & 29726 & 0 & 0 & 0 & 0 & 1728 & 920 & $2,267.90$ \\
\hline 2 & 2939 & 0 & 0 & 1932 & 785 & 0 & 0 & 325.19 \\
\hline 3 & 18428 & 2897 & 0 & 7888 & 3947 & 984 & 0 & $2,713.87$ \\
\hline 4 & 19922 & 5782 & 0 & 0 & 6300 & 1416 & 0 & $2,886.32$ \\
\hline 5 & 8557 & 1210 & 0 & 0 & 2421 & 312 & 875 & $1,060.73$ \\
\hline 6 & 13670 & 0 & 0 & 0 & 5659 & 699 & 595 & $1,600.11$ \\
\hline 7 & 12053 & 0 & 0 & 0 & 901 & 792 & 40 & $1,097.69$ \\
\hline 8 & 12708 & 2424 & 0 & 0 & 2576 & 816 & 0 & $1,586.78$ \\
\hline 9 & 4925 & 827 & 0 & 0 & 1013 & 0 & 0 & 611.69 \\
\hline 10 & 14722 & 0 & 3284 & 0 & 4094 & 240 & 0 & $2,143.47$ \\
\hline 11 & 16521 & 0 & 4334 & 0 & 3808 & 312 & 0 & $2,366.43$ \\
\hline 12 & 22509 & 3890 & 0 & 0 & 3122 & 1320 & 0 & $2,585.31$ \\
\hline 13 & 21655 & 3418 & 0 & 0 & 3275 & 720 & 920 & $2,664.01$ \\
\hline 14 & 27033 & 0 & 0 & 0 & 4096 & 1056 & 0 & $2,623.49$ \\
\hline 15 & 7468 & 0 & 0 & 0 & 1021 & 192 & 0 & $1,010.33$ \\
\hline 16 & 9604 & 0 & 0 & 0 & 2489 & 408 & 2205 & $1,138.54$ \\
\hline 17 & 2373 & 0 & 0 & 0 & 964 & 120 & 315 & 449.74 \\
\hline 18 & 14815 & 0 & 0 & 0 & 4931 & 3312 & 3929 & $2,662.48$ \\
\hline 19 & 6238 & 0 & 0 & 0 & 2577 & 480 & 196 & 906.37 \\
\hline 20 & 12204 & 2831 & 0 & 0 & 2635 & 552 & 0 & $1,726.44$ \\
\hline 21 & 23998 & 301 & 0 & 0 & 4227 & 744 & 0 & $2,656.64$ \\
\hline 22 & 25295 & 325 & 0 & 0 & 4009 & 1200 & 40 & $2,683.63$ \\
\hline Total & 327,363 & 23,905 & 7,618 & 9,820 & 64,850 & 17,403 & 10,035 & 39,767 \\
\hline
\end{tabular}


Table 3.5.3: Lumber Production and Energy Consumption during Each Shift in Sawmill 3

\begin{tabular}{|c|c|c|c|c|c|c|c|}
\hline Shift & $\begin{array}{c}\mathbf{4} \text { (4) } \\
\text { (Board } \\
\text { Feet) }\end{array}$ & $\begin{array}{c}\mathbf{5 / 4} \text { (Board } \\
\text { Feet) }\end{array}$ & $\begin{array}{c}\mathbf{8} / \mathbf{4} \text { (Board } \\
\text { Feet) }\end{array}$ & $\begin{array}{c}\text { Pallet } \\
\text { (Board } \\
\text { Feet) }\end{array}$ & $\begin{array}{c}\text { Cants } \\
\text { (Board } \\
\text { Feet) }\end{array}$ & $\begin{array}{c}\text { Ties } \\
\text { (Board } \\
\text { Feet) }\end{array}$ & $\begin{array}{c}\text { Energy } \\
\text { Consumption } \\
\text { (kWh) }\end{array}$ \\
\hline 1 & 15,602 & 4,529 & 0 & 1,778 & 0 & 0 & $2,325.14$ \\
\hline 2 & 23,999 & 0 & 0 & 2,053 & 0 & 0 & $2,963.61$ \\
\hline 3 & 28,479 & 0 & 0 & 3,671 & 0 & 0 & $4,946.48$ \\
\hline 4 & 7,017 & 0 & 0 & 1,143 & 0 & 0 & $1,122.39$ \\
\hline 5 & 37,240 & 0 & 12,636 & 937 & 9,975 & 0 & $4,115.69$ \\
\hline 6 & 42,719 & 0 & 5,782 & 1,947 & 10,698 & 0 & $5,189.42$ \\
\hline 7 & 50,940 & 0 & 11,125 & 1,063 & 11,645 & 0 & $5,064.19$ \\
\hline 8 & 36,660 & 2,807 & 0 & 3,983 & 0 & 0 & $5,632.85$ \\
\hline 9 & 36,390 & 12,699 & 0 & 6,849 & 0 & 0 & $5,495.17$ \\
\hline 10 & 27,376 & 5,048 & 0 & 4,683 & 0 & 0 & $5,192.91$ \\
\hline 11 & 34,148 & 6,919 & 0 & 5,592 & 0 & 0 & $5,310.84$ \\
\hline 12 & 30,093 & 2,398 & 0 & 4,044 & 0 & 0 & $5,041.39$ \\
\hline 13 & 6,594 & 1,471 & 0 & 748 & 0 & 0 & $1,003.77$ \\
\hline 14 & 29,710 & 0 & 4,486 & 2,293 & 0 & 0 & $3,722.08$ \\
\hline 15 & 1,885 & 0 & 0 & 69 & 411 & 0 & 686.85 \\
\hline 16 & 31,084 & 0 & 0 & 2,569 & 10,096 & 0 & $5,162.08$ \\
\hline 17 & 42,391 & 0 & 0 & 1,455 & 11,156 & 0 & $5,296.20$ \\
\hline 18 & 21,243 & 0 & 0 & 2,953 & 7,068 & 0 & $3,517.04$ \\
\hline 19 & 0 & 7,034 & 0 & 49 & 0 & 420 & $1,354.50$ \\
\hline 20 & 0 & 39,281 & 0 & 304 & 0 & 6,796 & $5,371.99$ \\
\hline 21 & 0 & 32,087 & 0 & 44 & 2,860 & 2,052 & $5,127.90$ \\
\hline 22 & 0 & 40,325 & 0 & 18 & 0 & 4,147 & $5,311.83$ \\
\hline 23 & 0 & 23,751 & 0 & 7 & 48 & 7,180 & $4,690.13$ \\
\hline 24 & 0 & 14,449 & 0 & 7 & 0 & 2,603 & $1,459.43$ \\
\hline 25 & 11,375 & 2,997 & 0 & 1,445 & 0 & 0 & $1,878.11$ \\
\hline 26 & 33,057 & 1,516 & 0 & 3,875 & 0 & 1,834 & $4,642.43$ \\
\hline 27 & 5,014 & 506 & 0 & 480 & 0 & 0 & 761.18 \\
\hline 28 & 33,810 & 0 & 0 & 2,644 & 0 & 0 & $4,700.60$ \\
\hline 29 & 21,115 & 0 & 0 & 2,088 & 4,326 & 0 & $4,710.43$ \\
\hline Total & $\mathbf{6 0 7 , 9 4 1}$ & $\mathbf{1 9 7 , 8 1 7}$ & $\mathbf{3 4 , 0 2 9}$ & $\mathbf{5 8 , 7 9 1}$ & $\mathbf{6 8 , 2 8 3}$ & $\mathbf{2 5 , 0 3 2}$ & $\mathbf{1 1 1 , 7 9 7}$ \\
\hline & & & & & & & \\
\hline
\end{tabular}


The energy consumption of individual motors in each shift was assigned to the lumber sizes based on the surface area cut by the motors. As shown in Figure 3.5.1, the head saw, re-saw and gang saws were cutting the lumber by length and width whereas edger by length and thickness and trimmer by width and thickness. All other motors were not directly involved with sawing operation. Hence, energy of other motors was allocated to lumber sizes based on the total surface area cut to produce that size lumber. Cants and Timbers are considered as left over parts after the lumber was sawn from the logs in head saw or re-saw and hence further sawing at edger and trimmer is not necessary for these parts. Hence, edger and trimmer energy consumption is not allocated to cants and timbers.
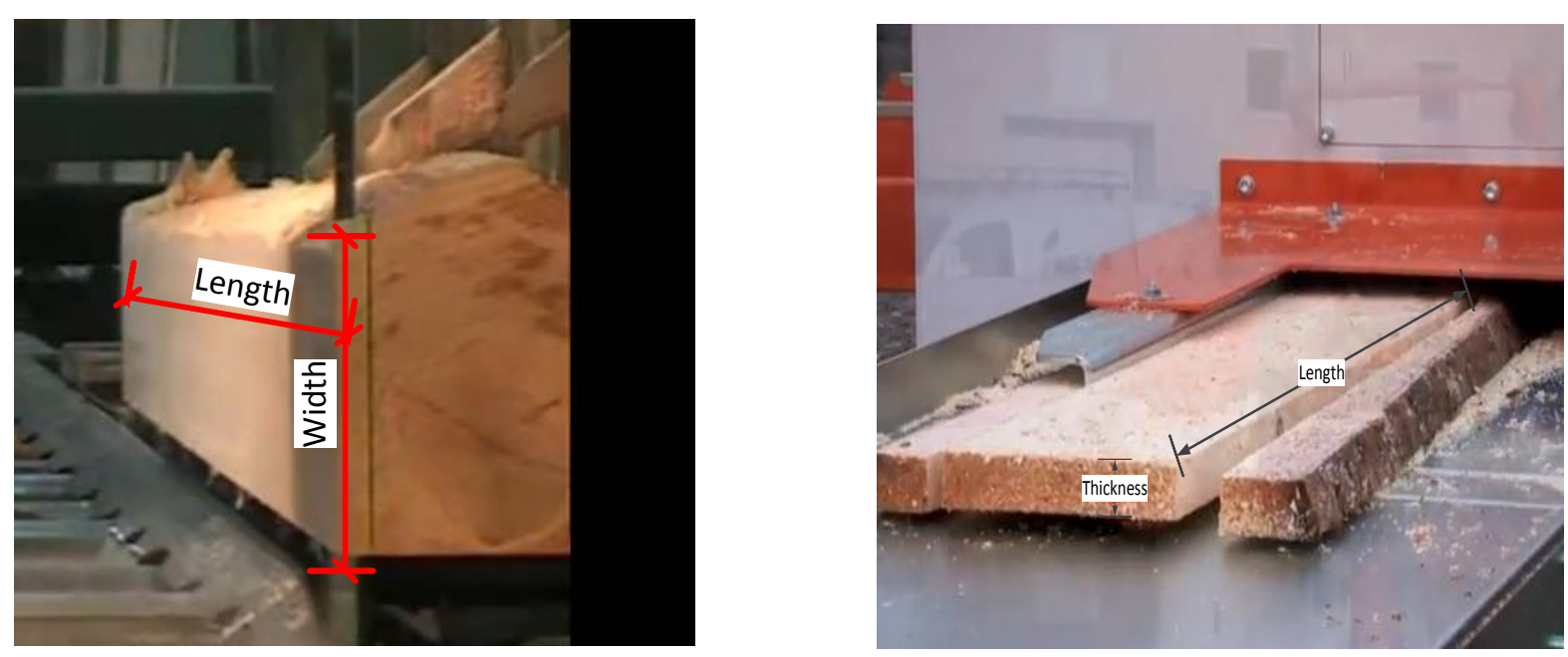

Main Saw

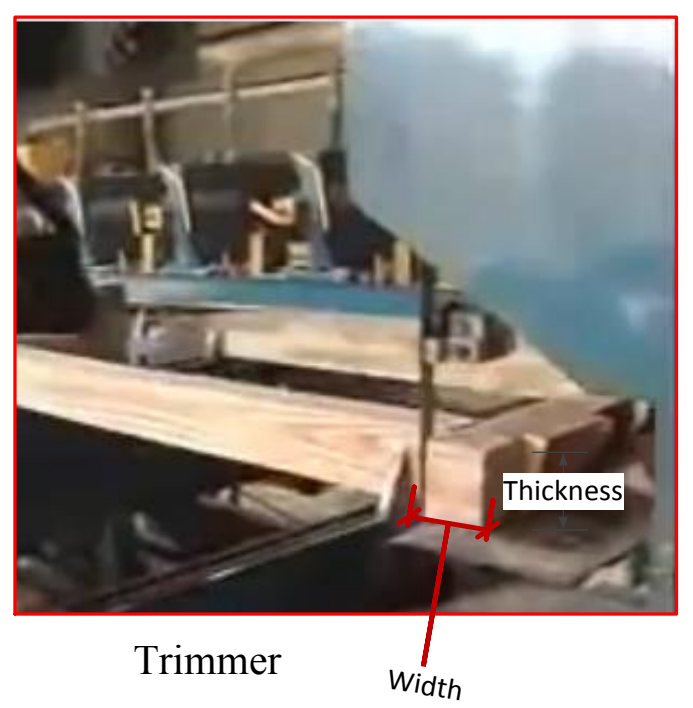

Edger

Figure 3.5.1: Surface Area Cut by Main Saw, Edger, and Trimmer 
As per the discussion with the plant personnel, lumber and cants were produced with different widths varying from 4 inches to 12 inches and timbers were produced with a standard width of 9 inches. The calculated energy consumption of the motors is allocated to the lumber and cants produced based on the standard width of 6 inches and to timber based on width of 9 inches. Then energy consumption of main saw, re-saw, and gang saw were extrapolated for different widths as explained later in this section.

As an example, the energy allocation of individual motors to $4 / 4$ size lumber in Sawmill 1 is shown below. During the first shift, from 6:00 AM to 10:30 AM, Sawmill 1 produced 4,652 board feet of Hickory lumber with $4 / 4$ inch thickness. As per the discussion with the sawmill personnel, the average length of lumber sawn was 10 feet and the average width of lumber was 6 inches $(0.5$ foot).

Surface area cut to produce 4,652 board feet of lumber is calculated as:

1 foot length $\mathrm{x} 1$ foot width $\mathrm{x} 1$ inch thickness = One board foot

$$
\begin{aligned}
\text { Total length of cut } & =\text { Total Board feet }(\text { width } \mathrm{x} \text { thickness }) \\
& =4,652 \mathrm{Bft} /(0.5 \text { foot } \times 1 \text { inch }) \\
& =9,304 \mathrm{ft}
\end{aligned}
$$

Surface area cut by main saw

$$
=\text { Total length cut } \mathrm{x} \text { Width }
$$$$
=9,304 \mathrm{ft} \times 0.5 \mathrm{ft}
$$$$
=4,652 \text { sq.ft }
$$

Surface area cut by edger

$=$ Total length cut $\mathrm{x}$ Thickness

$$
=9,304 \mathrm{ft} \times 1 \text { inch }=4,652 \mathrm{ft} \times(1 / 12 \mathrm{ft})
$$$$
=775.33 \text { sq.ft }
$$

Surface area cut by trimmer

$=$ Width $\mathrm{x}$ Thickness $\mathrm{x}$ No. of pieces cut

$$
=0.5 \text { foot } \times(1 / 12 \mathrm{ft}) \times(9,304 \mathrm{ft} / 10 \mathrm{ft})=38.77 \mathrm{sq} . \mathrm{ft}
$$


Surface area for rest of the motors $=$ Sum of surface areas cut by main saw, edger, and trimmer

$$
\begin{aligned}
& =4,652 \text { sq.ft }+775.33 \text { sq.ft }+38.77 \text { sq.ft } \\
& =5,466.10 \text { sq.ft }
\end{aligned}
$$

Factors of surface area cut for individual size lumber were calculated to allocate the individual motor consumption to that particular size of lumber. As an example, during the first shift in Sawmill 1, the total surface area cut by the main saw was 5,793.29 sq.ft. Out of which 4,652 sq.ft was cut to produce $4 / 4$ size lumber. Hence factor for the $4 / 4$ size lumber to allocate main saw energy consumption during that shift was,

Factor for main saw energy consumption for $4 / 4$ size $\quad=4,652$ sq.ft $/ 5,793.29$ sq.ft

$=0.8030$

Similarly factors for all motors for different sizes of lumber sawn during each shift were calculated and based on these factors individual motor's energy consumption was allocated to different sizes of lumber produced.

The energy consumption of the main saw in Sawmill 1 during $1^{\text {st }}$ shift was $228.07 \mathrm{kWh}$. Hence, energy consumed by the main saw to produce 4,652 board feet of $4 / 4$ inch thickness lumber can be calculated as,

Main saw energy consumption for $4 / 4$ " size during $1^{\text {st }}$ shift $=$ Factor $\mathrm{x} 228.07 \mathrm{kWh}$

$$
\begin{aligned}
& =0.8030 \times 228.07 \mathrm{kWh} \\
& =183.14 \mathrm{kWh}
\end{aligned}
$$

Similarly, energy consumed by other motors for producing $4 / 4$ " size lumber was calculated. The total energy consumption of all the motors for sawing 4,162 board feet of hickory lumber with 4/4 inch thickness was calculated as $903.83 \mathrm{kWh}$. The specific energy consumption (SEC) for sawing hickory of $4 / 4$ inch size during $1^{\text {st }}$ shift was calculated as,

Specific energy consumption $=$ Total energy consumption/board feet

$$
=903.83 / 4,162=0.217 \mathrm{kWh} / \text { board foot }
$$


Similarly, electricity consumption of all the motors were allocated to lumber production during all the shifts in all the 3 sawmills.

\subsubsection{Sensitivity analysis for Energy consumption of Main saw, Re-saw, and Gang saw for Different Widths produced}

In sawmills, most of the sawing operation is performed by main saw, re-saw, and gang saw. The energy consumption of these motors were allocated based on surface area cut as length by width of lumber. During visits to the sawmills, it was found that the electricity consumption of these motors did not increase proportionally with the width of the lumber sawn. Data were collected in Sawmill 3 to find the variation of electricity consumption of the re-saw for different widths of $4 / 4$ " size and 10 feet length of red oak lumber sawn. As shown in Table 3.5.4, the energy consumption is not varying at the same proportion of widths.

Table 3.5.4: Re-saw Electricity Consumption for Different Widths- Red Oak

\begin{tabular}{|c|c|c|c|c|c|}
\hline $\begin{array}{c}\text { Width } \\
\text { (Inches) }\end{array}$ & $\begin{array}{c}\text { Electricity } \\
\text { Consumption } \\
\text { (Amps) 'X }\end{array}$ & $\begin{array}{c}\text { Board Feet } \\
(\mathbf{Y})\end{array}$ & $\begin{array}{c}\text { Productivity } \\
\text { Factor } \\
(\mathbf{5 / Y})\end{array}$ & $\begin{array}{c}\text { Energy } \\
\text { Factors } \\
\text { (X/105) }\end{array}$ & $\begin{array}{c}\text { Combined } \\
\text { Factor }\end{array}$ \\
\hline 4 & 89 & 3.33 & 1.5 & 0.85 & 1.27 \\
\hline 5 & 95 & 4.17 & 1.2 & 0.90 & 1.09 \\
\hline 6 & 105 & 5.00 & 1 & 1.00 & 1.00 \\
\hline 8 & 117 & 6.67 & 0.75 & 1.11 & 0.84 \\
\hline 10 & 121 & 8.33 & 0.6 & 1.15 & 0.69 \\
\hline 12 & 130 & 10.00 & 0.5 & 1.24 & 0.62 \\
\hline
\end{tabular}




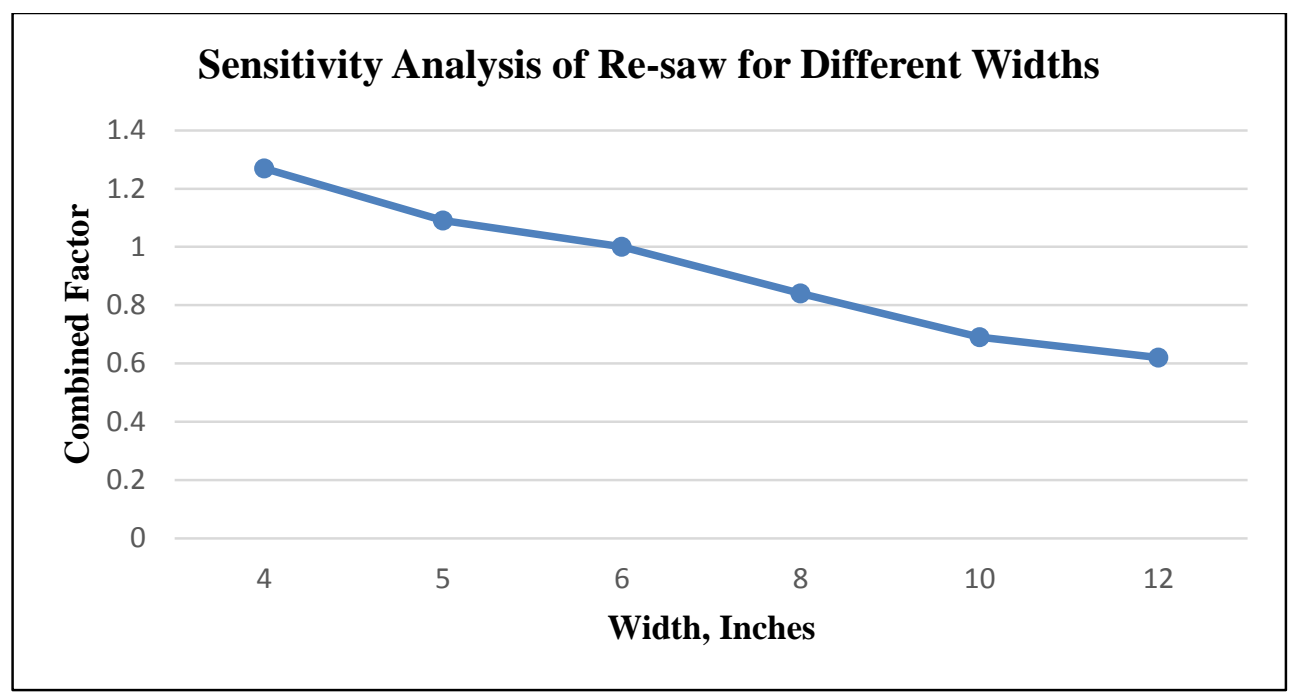

Figure 3.5.2: Sensitivity Analysis of Re-saw for Different Widths- Red Oak

These motors need to operate more time when sawing 4 inch width boards to produce one MBF of lumber compared to 12 inch width boards because of the less volume. As explained before, motors energy was allocated based on average width of 6 inches. The electricity consumption and board feet of 6 inch width is considered as standard consumption and standard board feet produced. Energy factors for other widths were calculated by dividing the electricity consumption with the standard electricity consumption i.e. 105 amps. Productivity factors were obtained by dividing board feet of particular size with standard board feet i.e. 5 board feet. Then the energy consumption of these motors for other widths $(4,8,10,12)$ are calculated by multiplying the total energy consumption by the calculated energy and productivity factors. The same factors were used for gang saw and main saw. The energy consumption is then allocated to lumber produced during each shift as explained before.

\subsection{Data Collection of Saw Material and Maintenance}

As discussed earlier, in a sawmill main saw and re-saw are the main equipment involved in sawing operation. The maintenance procedures of these saws and their material details were collected from all 3 sawmills. These conventional saws were compared with the latest available saws to find out the increase in productivity of lumber in Chapter 4. Although cost of the saws represents $1 \%$ of total sawmill costs, improving the quality of the saws can save raw material by reducing waste and improving the quality of lumber [46]. The material details and dimensions of the saws and maintenance procedures are shown in Table 3.6.1 and Table 3.6.2. 
Table 3.6.1: Saw Specifications in Sawmills

\begin{tabular}{|c|c|c|c|c|c|c|}
\hline & \multicolumn{3}{|c|}{ Main saw } & \multicolumn{3}{|c|}{ Re-saw } \\
\hline & Type of Saw & Material & Dimensions & Type of Saw & Material & Dimensions \\
\hline Sawmill 1 & Band Saw & Carbon Steel & $\begin{array}{l}\text { Length: } 45 \text { feet } \\
\text { Width: } 12 \text { inch } \\
\text { Thickness: } 0.071 \\
\text { inches }\end{array}$ & - & - & - \\
\hline Sawmill 2 & Circular Saw & Carbon Steel & $\begin{array}{l}\text { Diameter: } 58 \text { inch } \\
\text { Thickness: } 0.176 \\
\text { inch }\end{array}$ & Band Saw & $\begin{array}{c}\text { Carbon } \\
\text { Steel }\end{array}$ & $\begin{array}{l}\text { Length: } 21 \text { feet } \\
\text { Width: } 4.75 \text { inch } \\
\text { Thickness: } 0.048 \\
\text { inches }\end{array}$ \\
\hline Sawmill 3 & Band Saw & Carbon Steel & $\begin{array}{l}\text { Length: } 47 \text { feet } \\
\text { Width: } 12 \text { inch } \\
\text { Thickness: } 0.078 \\
\text { inches }\end{array}$ & Band Saw & $\begin{array}{c}\text { Carbon } \\
\text { Steel }\end{array}$ & $\begin{array}{l}\text { Length: } 40 \text { feet } \\
\text { Width: } 11 \text { inch } \\
\text { Thickness:0.078 } \\
\text { inches }\end{array}$ \\
\hline
\end{tabular}

Table 3.6.2: Maintenance Procedures of Saws

\begin{tabular}{|c|c|c|c|c|c|c|}
\hline & \multicolumn{3}{|c|}{ Main saw } & \multicolumn{3}{c|}{ Re-saw } \\
\hline & Runtime & $\begin{array}{c}\text { Grinding } \\
\text { Time }\end{array}$ & $\begin{array}{c}\text { Saw Changing } \\
\text { Time }\end{array}$ & Runtime & $\begin{array}{c}\text { Grinding } \\
\text { Time }\end{array}$ & $\begin{array}{c}\text { Saw Changing } \\
\text { Time }\end{array}$ \\
\hline Sawmill 1 & 4 Hours & 2 Hours & 10 Minutes & - & - & - \\
\hline Sawmill 2 & 3.5 Hours & 1 Hour & 10 Minutes & 4 hours & 1 hour & 15 Minutes \\
\hline Sawmill 3 & 5 hours & 3 hours & 5 Minutes & 5 Hours & 3 Hours & 5 Minutes \\
\hline
\end{tabular}




\section{$4 \quad$ Results and Discussion}

\subsection{Average Energy Consumption in Data Logged Sawmills vs Case Studies}

As discussed in Literature Review, there were some studies conducted to estimate the average energy consumption per $1 \mathrm{MBF}$. The average energy consumption of all 3 sawmills were compared with the case studies in Table 4.1.1. The average energy consumption is the ratio of total electrical energy consumption to the total lumber production without allocating energy consumption to specific sizes and species. The average energy consumptions of all the 3 sawmills were similar to previous studies.

Table 4.1.1: Average Energy Consumption vs Previous Studies

\begin{tabular}{|c|c|c|c|}
\hline & $\begin{array}{c}\text { Total Electricity } \\
\text { Consumption } \\
\text { (kWh) }\end{array}$ & $\begin{array}{c}\text { Total Lumber } \\
\text { Production } \\
\text { (Board Feet) }\end{array}$ & $\begin{array}{c}\text { Average Energy } \\
\text { Consumption for } \\
\mathbf{1 ~ M B F} \\
\text { (kWh/BF) }\end{array}$ \\
\hline Sawmill 1 & 35,154 & 420,687 & 83.56 \\
\hline Sawmill 2 & 39,767 & 460,994 & 86.26 \\
\hline Sawmill 3 & 111,797 & 991,893 & 112.71 \\
\hline \multicolumn{5}{|c|}{ Studies } \\
\hline Milota et al & - & - & 86.8 \\
\hline Milota et al & - & - & 67.9 \\
\hline Bergman and Bowe & - & - & 137 \\
\hline Li, McCurdy, and Pang & - & - & 124.7 \\
\hline Gopalakrishnan et al & - & \multicolumn{2}{|c}{} \\
\hline
\end{tabular}

From the average energy consumption, Sawmill 1 appears to be more energy efficient than other sawmills. As shown in Table 4.1.2, Sawmill 1 produced a higher percentage of cants and timbers compared to other sawmills. Since, cants and timbers doesn't require more sawing operation, average consumption of the Sawmill 1 is less than other sawmills. Allocating energy consumption to individual size lumber will give a better picture of energy efficiency in each sawmill.

Table 4.1.2: Percentage of Lumber Produced in Each sawmill

\begin{tabular}{|c|c|c|c|}
\hline Sawmill & $\begin{array}{c}\text { 4/4"+5/4"+6/4"+8/4" } \\
\text { (Board Feet) }\end{array}$ & $\begin{array}{c}\text { Cants + Timbers } \\
\text { (Board Feet) }\end{array}$ & $\begin{array}{c}\text { Total } \\
\text { Lumber } \\
\text { (Board Feet) }\end{array}$ \\
\hline Sawmill 1 & $225,178(53.53 \%)$ & $195,509(46.47 \%)$ & 420,687 \\
\hline Sawmill 2 & $433,556(94.05 \%)$ & $27,438(5.95 \%)$ & 460,994 \\
\hline Sawmill 3 & $898,578(90.59 \%)$ & $93,315(9.41 \%)$ & 991,893 \\
\hline
\end{tabular}




\section{2}

Energy Consumption and Lumber Production in Sawmills

The total energy consumption in each sawmill during data logging period and its lumber production are shown in Figures 4.2.1, 4.2.2, and 4.3.3. In all the 3 sawmills both energy consumption and lumber production were following the same pattern except for some shifts. Energy consumption was usually high when more lumber was produced. Some outliers in each saw mill are briefly discussed. In Sawmill 1, as shown in Figure 4.2.1, energy consumptions during shifts 33 and 35 were almost same (1,560 kWh, 1,557 kWh) but lumber production $(10,962 \mathrm{BF}, 17,085) \mathrm{BF}$ varied since more timber was produced in shift 35 .

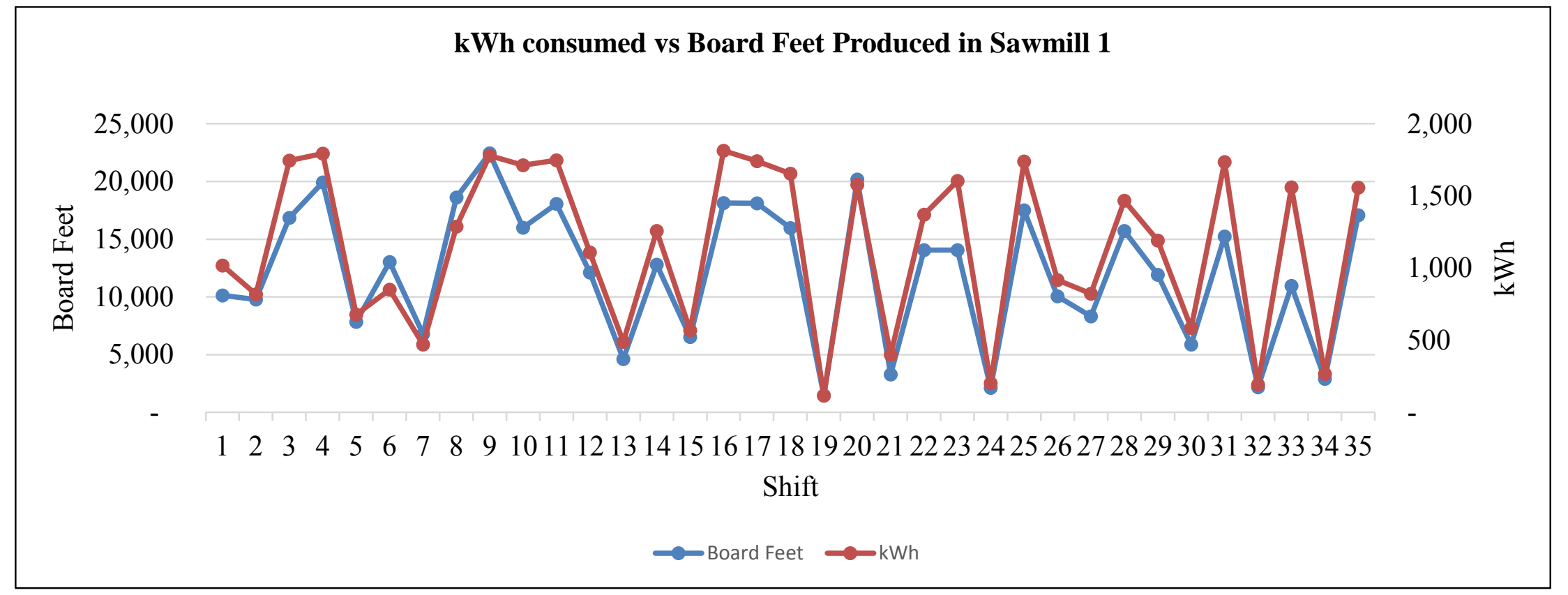

Figure 4.2.1: Energy Consumption vs Lumber Production in Sawmill 1 
In Sawmill 2, almost all the shifts followed the same pattern and no major outliers were found since cants and timber production was limited in all the shifts.

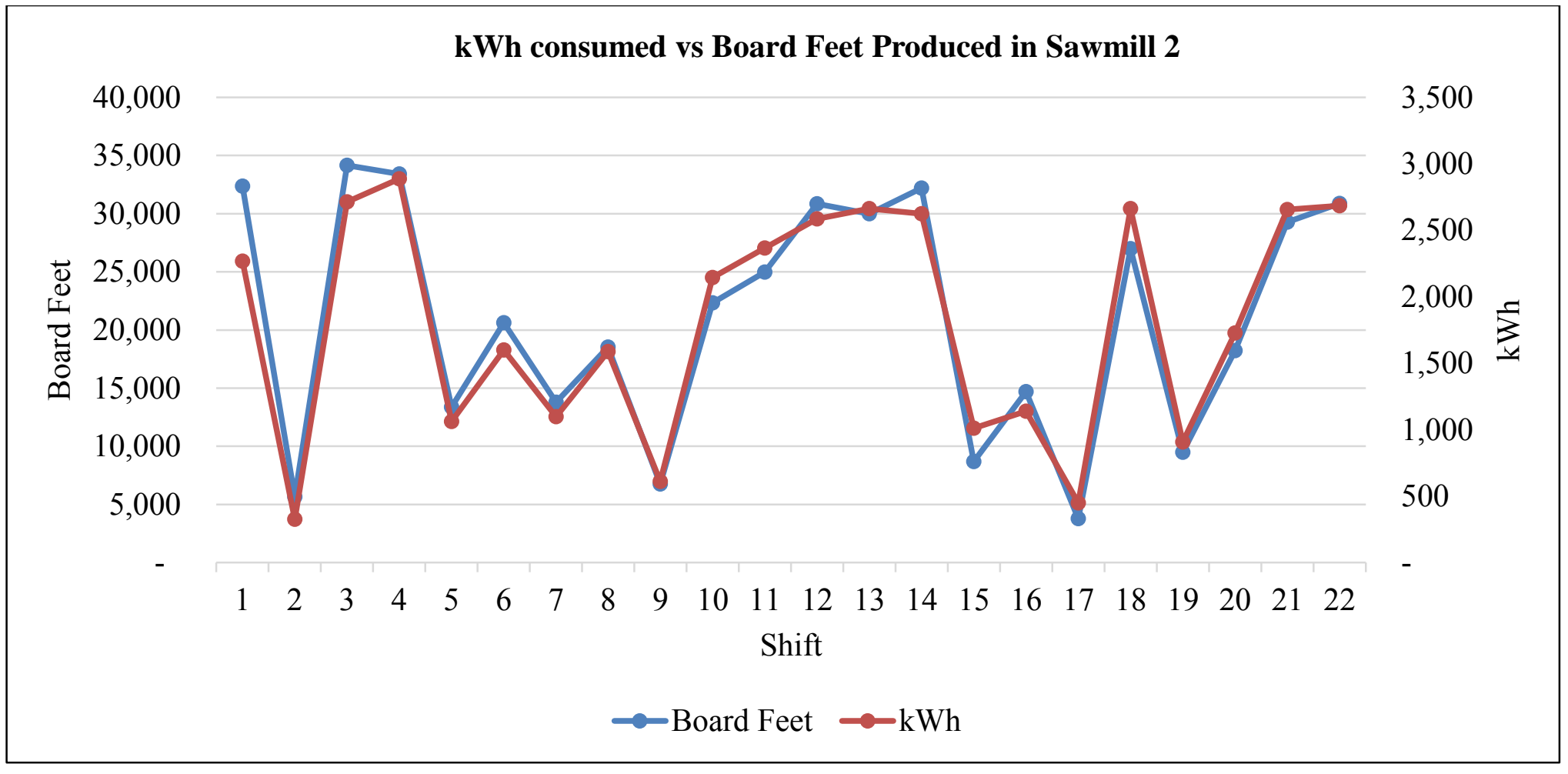

Figure 4.2.2: Energy Consumption vs Lumber Production in Sawmill 2 
In Sawmill 3, production and energy consumption didn't follow a regular pattern due to two main reasons. The first reason is for the shifts $4,13,15,27$ the energy consumption was closer to lumber production in the graph since these shifts produced low lumber volume. The second reason is for shifts 5,6,7 the energy consumption was closer to lumber production in the graph since these shifts produced more of cants and timbers than the grade lumber and hence consumed less energy.

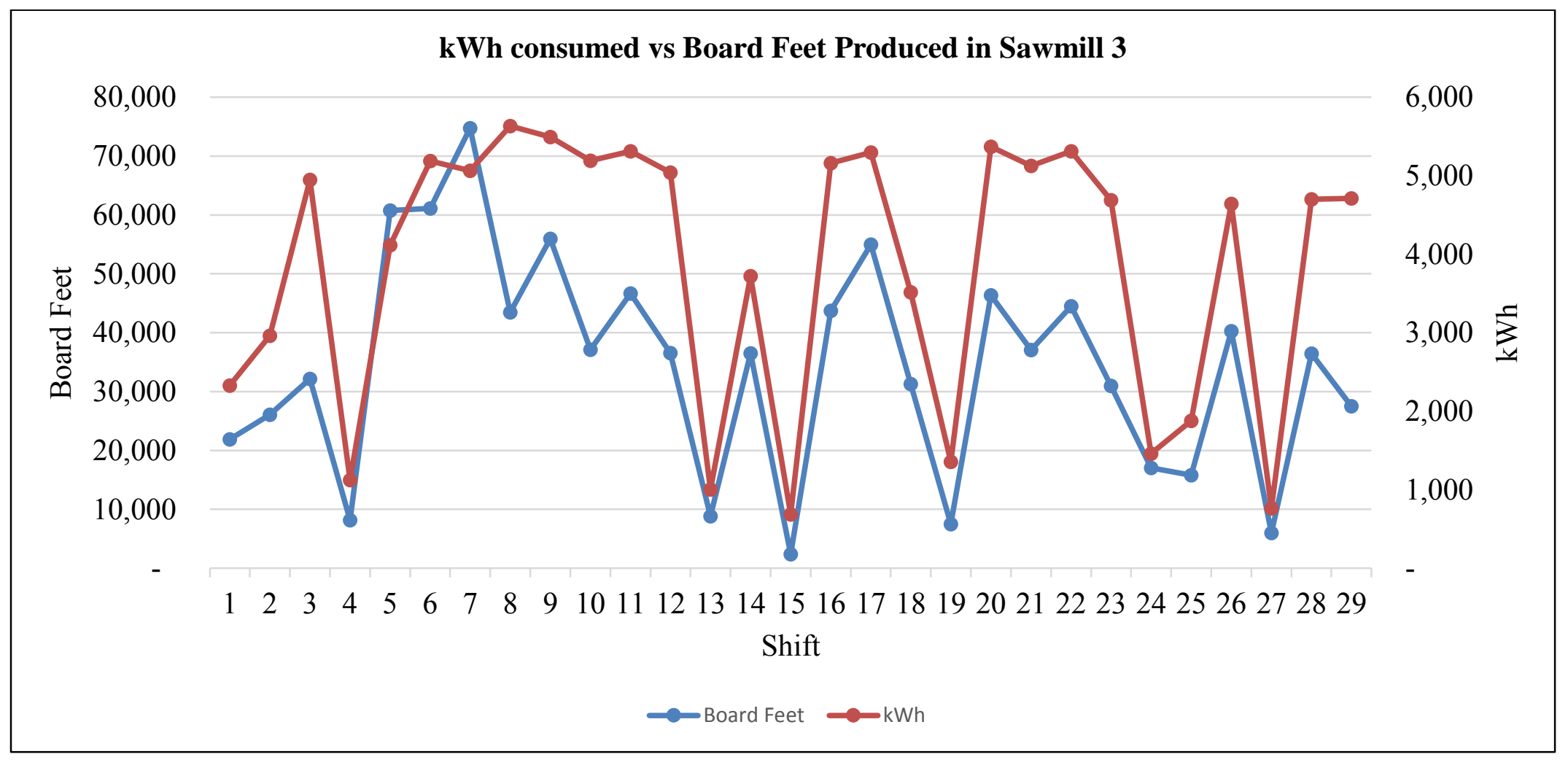

Figure 4.2.3: Energy Consumption vs Lumber Production in Sawmill 3 


\subsection{Energy consumption of different species for different sizes}

\section{Hickory:}

Hickory was produced in Sawmill 1 and Sawmill 2. Sawmill 1 produced 27,578 board feet and Sawmill 2 produced 8,681 board feet of hickory lumber during the study period. The total lumber production of different sizes and different widths with their energy consumption in each sawmill are shown in Table 4.3.1 and Table 4.3.2. The energy consumption per $1 \mathrm{MBF}$ of different sizes is shown in Figure 4.3.1. It is obvious that the lumber with less thickness and width needs more sawing time to produce 1,000 board feet (1 MBF) and hence will consume more electrical energy. Since 4/4 size lumber and pallet material were produced with same sizes, both consumed same amount of electrical energy. For the analysis in this chapter, specific energy consumption of $4 / 4$ size is only mentioned which also represents the energy consumption of pallet material. As shown in the figure, 4 inch width lumber consumed more energy than other widths.

Table 4.3.1: Total Energy Consumption of Different Sizes in Sawmill 1-Hickory

\begin{tabular}{|l|c|c|c|c|c|c|c|}
\hline \multirow{2}{*}{ Size } & \multirow{2}{*}{ Total BF } & \multicolumn{7}{c|}{ Energy Consumption (kWh) } \\
\cline { 3 - 8 } & & $\begin{array}{c}\mathbf{4} \text { inch } \\
\text { Width }\end{array}$ & $\begin{array}{c}\text { 6 inch } \\
\text { Width }\end{array}$ & $\begin{array}{c}\mathbf{8} \text { inch } \\
\text { Width }\end{array}$ & $\begin{array}{c}\mathbf{1 0} \text { inch } \\
\text { Width }\end{array}$ & $\begin{array}{c}\text { 12 inch } \\
\text { Width }\end{array}$ & $\begin{array}{c}\text { 9 inch } \\
\text { Width }\end{array}$ \\
\hline 4/4 size & 11,908 & $2,213.26$ & $2,018.72$ & $1,903.95$ & $1,798.23$ & $1,748.04$ & - \\
\hline Cants (5" thick) & 4,725 & 141.75 & 131.77 & 125.65 & 119.16 & 116.47 & - \\
\hline $\begin{array}{l}\text { Ties (7" thick x 9" } \\
\text { wide) }\end{array}$ & 10,391 & - & - & - & - & - & 211.46 \\
\hline
\end{tabular}

Table 4.3.2: Specific Energy Consumption of Different Sizes in Sawmill 1-Hickory

\begin{tabular}{|l|c|c|c|c|c|c|}
\hline \multirow{2}{*}{ Size } & \multicolumn{5}{|c|}{ Specific Energy Consumption (kWh/MBF) } \\
\cline { 2 - 7 } & $\begin{array}{c}\text { 4 inch } \\
\text { Width }\end{array}$ & $\begin{array}{c}\text { 6 inch } \\
\text { Width }\end{array}$ & $\begin{array}{c}\text { 8 inch } \\
\text { Width }\end{array}$ & $\begin{array}{c}\text { 10 inch } \\
\text { Width }\end{array}$ & $\begin{array}{c}\text { 12 inch } \\
\text { Width }\end{array}$ & $\begin{array}{c}\text { 9 inch } \\
\text { Width }\end{array}$ \\
\hline $4 / 4$ size & 185.86 & 169.53 & 159.89 & 151.01 & 146.80 & - \\
\hline Cants (5" thick) & 30.00 & 27.89 & 26.59 & 27.23 & 24.65 & - \\
\hline $\begin{array}{l}\text { Ties (7" thick x 9" } \\
\text { wide) }\end{array}$ & - & - & - & - & - & 20.35 \\
\hline
\end{tabular}


Table 4.3.3: Total Energy Consumption of Different Sizes in Sawmill 2-Hickory

\begin{tabular}{|l|c|c|c|c|c|c|}
\hline \multirow{2}{*}{ Size } & \multirow{2}{*}{ Total BF } & \multicolumn{5}{|c|}{ Energy Consumption (kWh) } \\
\cline { 3 - 7 } & & $\begin{array}{c}\text { 4 inch } \\
\text { Width }\end{array}$ & $\begin{array}{c}\text { 6 inch } \\
\text { Width }\end{array}$ & $\begin{array}{c}\text { 8 inch } \\
\text { Width }\end{array}$ & $\begin{array}{c}\text { 10 inch } \\
\text { Width }\end{array}$ & $\begin{array}{c}\text { 12 inch } \\
\text { Width }\end{array}$ \\
\hline $4 / 4$ size & 7,468 & 909.29 & 883.16 & 867.68 & 853.23 & 846.46 \\
\hline Cants (3" thick) & 192 & 6.55 & 6.52 & 6.51 & 6.44 & 6.29 \\
\hline
\end{tabular}

Table 4.3.4: Specific Energy Consumption of Different Sizes in Sawmill 2-Hickory

\begin{tabular}{|l|c|c|c|c|c|}
\hline \multirow{2}{*}{ Size } & \multicolumn{5}{|c|}{ Specific Energy Consumption $(\mathbf{k W h} / \mathrm{MBF})$} \\
\cline { 2 - 6 } & $\begin{array}{c}\text { 4 inch } \\
\text { Width }\end{array}$ & $\begin{array}{c}\text { 6 inch } \\
\text { Width }\end{array}$ & $\begin{array}{c}\text { 8 inch } \\
\text { Width }\end{array}$ & $\begin{array}{c}\text { 10 inch } \\
\text { Width }\end{array}$ & $\begin{array}{c}\text { 12 inch } \\
\text { Width }\end{array}$ \\
\hline 4/4 size & 121.76 & 118.26 & 116.19 & 114.25 & 113.34 \\
\hline Cants (3" thick) & 34.11 & 33.96 & 33.91 & 33.54 & 32.76 \\
\hline
\end{tabular}

Specific energy consumption of Sawmill 1 for 4/4 size hickory lumber varied between $146.80 \mathrm{kWh}$ $\sim 185.86 \mathrm{kWh}$ whereas for Sawmill 2 it was $113.34 \mathrm{kWh} \sim 121.76 \mathrm{kWh}$.

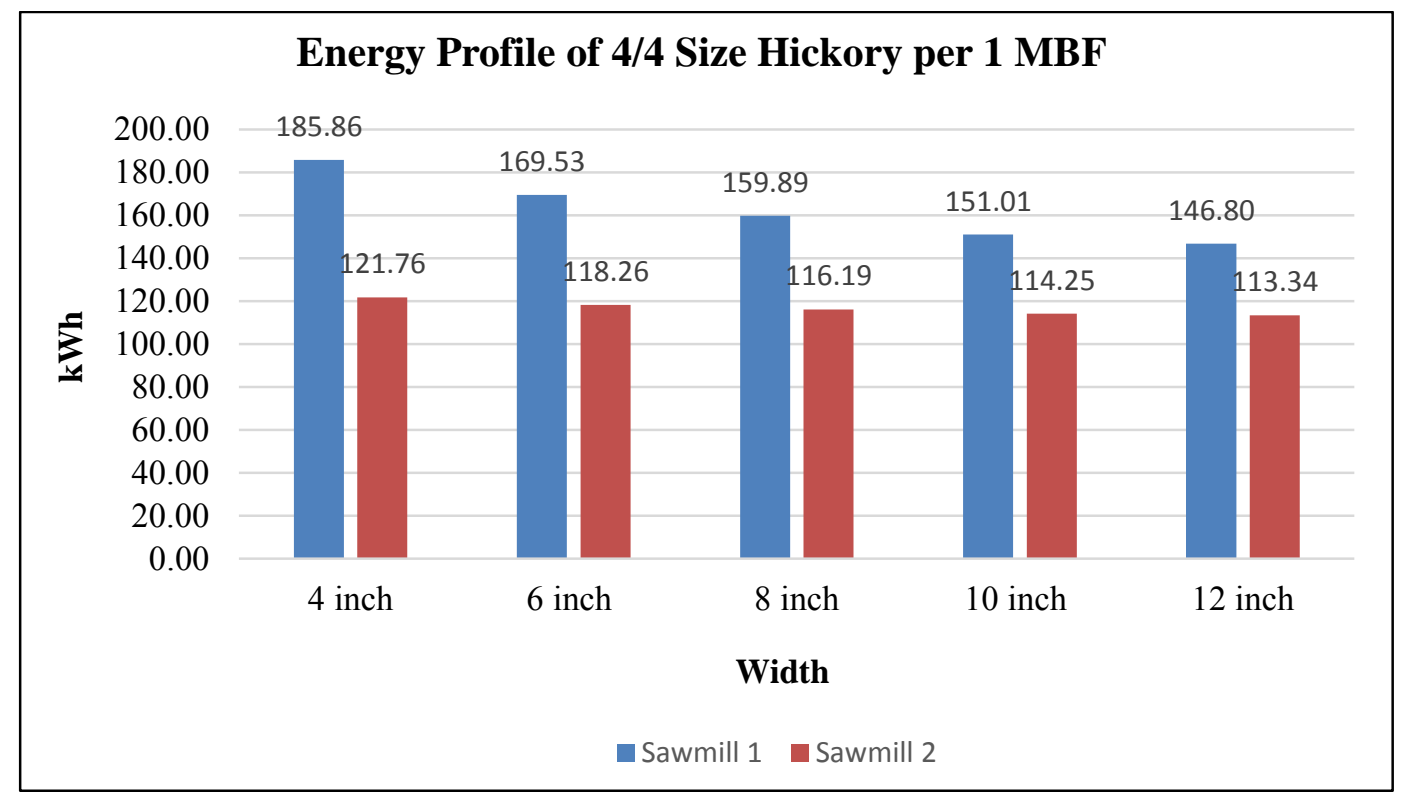

Figure 4.3.1: Energy Profile of 4/4 Size Lumber with Different Widths - Hickory

\section{Hard Maple:}

All the 3 sawmills produced hard maple. A total of 214,468 board feet of lumber was produced from 3 sawmills. Total energy consumption and lumber production for different sizes in each sawmill are shown below. 
Table 4.3.5: Total Energy Consumption of Different Sizes in Sawmill 1-Hard Maple

\begin{tabular}{|l|c|c|c|c|c|c|c|}
\hline \multirow{2}{*}{ Size } & \multirow{2}{*}{ Total BF } & \multicolumn{6}{|c|}{ Energy Consumption (kWh) } \\
\cline { 3 - 8 } & $\begin{array}{c}\text { Winch } \\
\text { Width }\end{array}$ & $\begin{array}{c}\text { 6 inch } \\
\text { Width }\end{array}$ & $\begin{array}{c}\text { 8 inch } \\
\text { Width }\end{array}$ & $\begin{array}{c}\text { 10 inch } \\
\text { Width }\end{array}$ & $\begin{array}{l}\text { 12 inch } \\
\text { Width }\end{array}$ & $\begin{array}{l}\text { 9 inch } \\
\text { Width }\end{array}$ \\
\hline $4 / 4$ size & 15,656 & $2,234.10$ & $2,034.24$ & $1,916.01$ & $1,805.97$ & $1,754.25$ & - \\
\hline Cants (3.5" thick) & 1,215 & 40.34 & 37.39 & 35.58 & 33.67 & 32.88 & - \\
\hline $\begin{array}{l}\text { Ties (7" thick x 9" } \\
\text { wide) }\end{array}$ & 6,083 & - & - & - & - & - & 102.60 \\
\hline
\end{tabular}

Table 4.3.6: Specific Energy Consumption of Different Sizes in Sawmill 1-Hard Maple

\begin{tabular}{|l|c|c|c|c|c|c|}
\hline \multirow{2}{*}{ Size } & \multicolumn{5}{|c|}{ Specific Energy Consumption (kWh/MBF) } \\
\cline { 2 - 7 } & $\begin{array}{c}\text { 4 inch } \\
\text { Width }\end{array}$ & $\begin{array}{c}\text { 6 inch } \\
\text { Width }\end{array}$ & $\begin{array}{c}\text { 8 inch } \\
\text { Width }\end{array}$ & $\begin{array}{c}\text { 10 inch } \\
\text { Width }\end{array}$ & $\begin{array}{c}\text { 12 inch } \\
\text { Width }\end{array}$ & $\begin{array}{c}\text { 9 inch } \\
\text { Width }\end{array}$ \\
\hline 4/4 size & 142.70 & 129.93 & 122.38 & 115.35 & 112.05 & - \\
\hline Cants (3.5" thick) & 33.20 & 30.77 & 29.28 & 27.71 & 27.06 & - \\
\hline $\begin{array}{l}\text { Ties (7" thick x 9" } \\
\text { wide) }\end{array}$ & - & - & - & - & - & 16.87 \\
\hline
\end{tabular}

Table 4.3.7: Total Energy Consumption of Different Sizes in Sawmill 2-Hard Maple

\begin{tabular}{|l|c|c|c|c|c|c|c|}
\hline \multirow{2}{*}{ Size } & \multirow{2}{*}{ Total BF } & \multicolumn{6}{|c|}{ Energy Consumption (kWh) } \\
\cline { 3 - 9 } & $\begin{array}{c}\mathbf{4} \text { inch } \\
\text { Width }\end{array}$ & $\begin{array}{c}\text { 6 inch } \\
\text { Width }\end{array}$ & $\begin{array}{c}\mathbf{8} \text { inch } \\
\text { Width }\end{array}$ & $\begin{array}{c}\text { 10 inch } \\
\text { Width }\end{array}$ & $\begin{array}{c}\text { 12 inch } \\
\text { Width }\end{array}$ & $\begin{array}{c}\text { 9 inch } \\
\text { Width }\end{array}$ \\
\hline $4 / 4$ size & 44,164 & $4,215.81$ & $4,045.05$ & $3,943.79$ & $3,848.50$ & $3,804.20$ & - \\
\hline $5 / 4$ size & 7,308 & 582.88 & 554.13 & 537.31 & 522.52 & 515.15 & - \\
\hline Cants (3" thickness) & 2,040 & 52.70 & 52.68 & 52.48 & 52.24 & 52.23 & - \\
\hline $\begin{array}{l}\text { Ties (7" thick x 9" } \\
\text { width) }\end{array}$ & 920 & - & - & - & - & - & 10.65 \\
\hline
\end{tabular}

Table 4.3.8: Specific Energy Consumption of Different Sizes in Sawmill 2-Hard Maple

\begin{tabular}{|l|c|c|c|c|c|c|}
\hline \multirow{2}{*}{ Size } & \multicolumn{5}{|c|}{ Specific Energy Consumption (kWh/MBF) } \\
\cline { 2 - 7 } & $\begin{array}{c}\text { 4 inch } \\
\text { Width }\end{array}$ & $\begin{array}{c}\text { 6 inch } \\
\text { Width }\end{array}$ & $\begin{array}{c}\text { 8 inch } \\
\text { Width }\end{array}$ & $\begin{array}{l}\text { 10 inch } \\
\text { Width }\end{array}$ & $\begin{array}{c}\text { 12 inch } \\
\text { Width }\end{array}$ & $\begin{array}{c}\text { 9 inch } \\
\text { Width }\end{array}$ \\
\hline $4 / 4$ size & 95.46 & 91.59 & 89.30 & 87.14 & 86.14 & - \\
\hline $5 / 4$ size & 79.76 & 75.83 & 73.52 & 71.50 & 70.49 & \\
\hline Cants (3" thick) & 25.83 & 25.82 & 25.73 & 25.61 & 25.60 & - \\
\hline $\begin{array}{l}\text { Ties (7" thick x 9" } \\
\text { wide) }\end{array}$ & - & - & - & - & - & 11.58 \\
\hline
\end{tabular}


Table 4.3.9: Total Energy Consumption of Different Sizes in Sawmill 3-Hard Maple

\begin{tabular}{|l|c|c|c|c|c|c|}
\hline \multirow{2}{*}{ Size } & \multirow{2}{*}{ Total BF } & \multicolumn{5}{|c|}{ Energy Consumption $(\mathbf{k W h})$} \\
\cline { 3 - 7 } & & $\begin{array}{c}\text { 4 inch } \\
\text { Width }\end{array}$ & $\begin{array}{c}\text { 6 inch } \\
\text { Width }\end{array}$ & $\begin{array}{c}\text { 8 inch } \\
\text { Width }\end{array}$ & $\begin{array}{c}\text { 10 inch } \\
\text { Width }\end{array}$ & $\begin{array}{c}\text { 12 inch } \\
\text { Width }\end{array}$ \\
\hline $4 / 4$ size & 114,420 & $18,413.32$ & $16,554.85$ & $15,453.76$ & $14,422.42$ & $13,940.69$ \\
\hline Cants (3.5" thick) & 4,326 & 202.80 & 184.92 & 174.08 & 162.90 & 158.16 \\
\hline
\end{tabular}

Table 4.3.10: Specific Energy Consumption of Different Sizes in Sawmill 3-Hard Maple

\begin{tabular}{|l|c|c|c|c|c|}
\hline \multirow{2}{*}{ Size } & \multicolumn{5}{|c|}{ Specific Energy Consumption (kWh/MBF) } \\
\cline { 2 - 6 } & $\begin{array}{c}\text { 4 inch } \\
\text { Width }\end{array}$ & $\begin{array}{c}\text { 6 inch } \\
\text { Width }\end{array}$ & $\begin{array}{c}\text { 8 inch } \\
\text { Width }\end{array}$ & $\begin{array}{c}\text { 10 inch } \\
\text { Width }\end{array}$ & $\begin{array}{c}\text { 12 inch } \\
\text { Width }\end{array}$ \\
\hline $4 / 4$ size & 160.93 & 144.68 & 135.06 & 126.05 & 121.84 \\
\hline Cants (3.5" thick) & 46.88 & 42.75 & 40.24 & 37.66 & 36.56 \\
\hline
\end{tabular}

As shown in Figure 4.3.2, Sawmill 3 consumed more energy per $1 \mathrm{MBF}$ of 4/4 size hard maple lumber compared to other 2 sawmills. Sawmill 2 is found to be more efficient than other 2 mills by consuming $86.14 \mathrm{kWh} \sim 95.46 \mathrm{kWh}$ of electrical energy per $1 \mathrm{MBF}$.

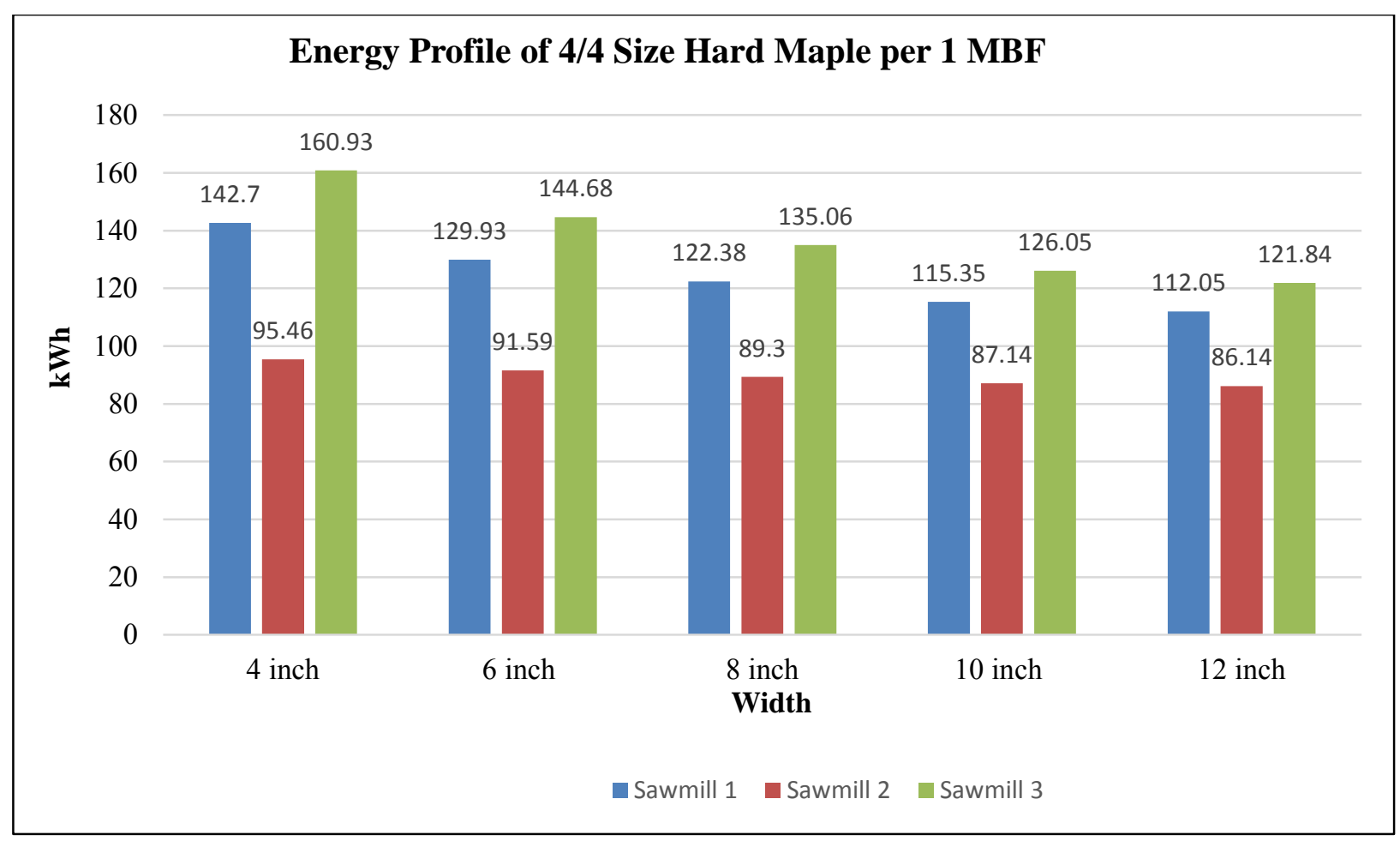

Figure 4.3.2: Energy Profile of 4/4 Size Lumber with Different Widths - Hard Maple 
Red Oak:

Red oak was the most frequently sawn wood species in all the 3 sawmills, a total of 690,254 board feet of lumber of different sizes was produced in 3 sawmills during the study period.

Table 4.3.11: Total Energy Consumption of Different Sizes in Sawmill 1-Red Oak

\begin{tabular}{|l|c|c|c|c|c|c|c|}
\hline \multirow{2}{*}{ Size } & \multirow{2}{*}{ Total BF } & \multicolumn{6}{|c|}{ Energy Consumption (kWh) } \\
\cline { 3 - 9 } & $\begin{array}{c}\text { W inch } \\
\text { Width }\end{array}$ & $\begin{array}{c}\text { 6 inch } \\
\text { Width }\end{array}$ & $\begin{array}{c}\mathbf{8} \text { inch } \\
\text { Width }\end{array}$ & $\begin{array}{c}\text { 10 inch } \\
\text { Width }\end{array}$ & $\begin{array}{c}\text { 12 inch } \\
\text { Width }\end{array}$ & $\begin{array}{c}\text { 9 inch } \\
\text { Width }\end{array}$ \\
\hline 4/4 Size & 90,781 & $14,183.86$ & $12,913.40$ & $12,162.39$ & $11,465.35$ & $11,136.84$ & - \\
\hline 8/4 Size & 6,716 & 618.45 & 556.34 & 520.21 & 489.10 & 473.29 & - \\
\hline Cants (5" thick) & 25,415 & 626.48 & 580.63 & 552.60 & 522.86 & 510.60 & - \\
\hline Cants (3.5" thick) & 3,566 & 183.97 & 170.02 & 161.49 & 152.62 & 148.88 & - \\
\hline $\begin{array}{l}\text { Ties (7" thick x 9" } \\
\text { wide) }\end{array}$ & 58,514 & - & - & - & - & - & $1,169.50$ \\
\hline
\end{tabular}

Table 4.3.12: Specific Energy Consumption of Different Sizes in Sawmill 1-Red Oak

\begin{tabular}{|l|c|c|c|c|c|c|}
\hline \multirow{2}{*}{ Size } & \multicolumn{5}{|c|}{ Specific Energy Consumption (kWh/MBF) } \\
\cline { 2 - 8 } & $\begin{array}{c}\text { 4 inch } \\
\text { Width }\end{array}$ & $\begin{array}{c}\text { 6 inch } \\
\text { Width }\end{array}$ & $\begin{array}{l}\text { 8 inch } \\
\text { Width }\end{array}$ & $\begin{array}{l}\mathbf{1 0} \text { inch } \\
\text { Width }\end{array}$ & $\begin{array}{l}\text { 12 inch } \\
\text { Width }\end{array}$ & $\begin{array}{c}\text { 9 inch } \\
\text { Width }\end{array}$ \\
\hline 4/4 Size & 156.24 & 142.25 & 133.98 & 126.30 & 122.68 & - \\
\hline 8/4 Size & 92.09 & 82.84 & 77.46 & 72.83 & 70.47 & - \\
\hline Cants (5" thick) & 24.65 & 22.85 & 21.74 & 20.57 & 20.09 & - \\
\hline Cants (3.5" thick) & 51.59 & 47.68 & 45.29 & 42.80 & 41.75 & - \\
\hline $\begin{array}{l}\text { Ties (7" thick x 9" } \\
\text { wide) }\end{array}$ & - & - & - & - & - & 19.99 \\
\hline
\end{tabular}

Table 4.3.13: Total Energy Consumption of Different Sizes in Sawmill 2-Red Oak

\begin{tabular}{|l|c|c|c|c|c|c|c|}
\hline \multirow{2}{*}{ Size } & \multirow{2}{*}{ Total BF } & \multicolumn{6}{|c|}{ Energy Consumption (kWh) } \\
\cline { 3 - 9 } & $\begin{array}{c}\mathbf{4} \text { inch } \\
\text { Width }\end{array}$ & $\begin{array}{c}\text { 6 inch } \\
\text { Width }\end{array}$ & $\begin{array}{c}\text { 8 inch } \\
\text { Width }\end{array}$ & $\begin{array}{c}\text { 10 inch } \\
\text { Width }\end{array}$ & $\begin{array}{c}\text { 12 inch } \\
\text { Width }\end{array}$ & $\begin{array}{c}\text { 9 inch } \\
\text { Width }\end{array}$ \\
\hline 4/4 Size & 124,051 & $11,776.01$ & $11,321.44$ & $11,051.61$ & $10,796.18$ & $10,678.20$ & - \\
\hline 5/4 Size & 15,770 & $1,270.86$ & $1,211.00$ & $1,175.93$ & $1,144.95$ & $1,129.59$ & - \\
\hline 8/4 Size & 9,820 & 522.55 & 488.53 & 468.87 & 453.14 & 444.46 & - \\
\hline Cants (3" thick) & 6,024 & 156.41 & 157.53 & 157.87 & 156.73 & 156.90 & - \\
\hline $\begin{array}{l}\text { Ties (7" thick x 9" } \\
\text { wide) }\end{array}$ & 915 & - & - & - & - & - & 9.75 \\
\hline
\end{tabular}


Table 4.3.14: Specific Energy Consumption of Different Sizes in Sawmill 2-Red Oak

\begin{tabular}{|l|c|c|c|c|c|c|}
\hline \multirow{2}{*}{ Size } & \multicolumn{6}{|c|}{ Specific Energy Consumption (kWh/MBF) } \\
\cline { 2 - 7 } & $\begin{array}{c}\text { 4 inch } \\
\text { Width }\end{array}$ & $\begin{array}{c}\text { 6 inch } \\
\text { Width }\end{array}$ & $\begin{array}{c}\text { 8 inch } \\
\text { Width }\end{array}$ & $\begin{array}{c}\text { 10 inch } \\
\text { Width }\end{array}$ & $\begin{array}{c}\text { 12 inch } \\
\text { Width }\end{array}$ & $\begin{array}{c}\text { 9 inch } \\
\text { Width }\end{array}$ \\
\hline 4/4 Size & 94.93 & 91.26 & 89.09 & 87.03 & 86.08 & - \\
\hline 5/4 Size & 80.59 & 76.79 & 74.57 & 72.60 & 71.63 & - \\
\hline 8/4 Size & 53.21 & 49.75 & 47.75 & 46.14 & 45.26 & - \\
\hline Cants (3" thick) & 25.96 & 26.15 & 26.21 & 26.02 & 26.05 & - \\
\hline $\begin{array}{l}\text { Ties (7" thick x 9" } \\
\text { wide) }\end{array}$ & - & - & - & - & - & 10.66 \\
\hline
\end{tabular}

Table 4.3.15: Total Energy Consumption of Different Sizes in Sawmill 3-Red Oak

\begin{tabular}{|l|c|c|c|c|c|c|c|}
\hline \multirow{2}{*}{ Size } & \multirow{2}{*}{ Total BF } & \multicolumn{7}{c|}{ Energy Consumption (kWh) } \\
\cline { 3 - 8 } & & $\begin{array}{c}\text { 4 inch } \\
\text { Width }\end{array}$ & $\begin{array}{c}\text { 6 inch } \\
\text { Width }\end{array}$ & $\begin{array}{c}\text { 8 inch } \\
\text { Width }\end{array}$ & $\begin{array}{c}\text { 10 inch } \\
\text { Width }\end{array}$ & $\begin{array}{c}\text { 12 inch } \\
\text { Width }\end{array}$ & $\begin{array}{c}\text { 9 inch } \\
\text { Width }\end{array}$ \\
\hline 4/4 Size & 236,309 & $32,524.95$ & $29,121.97$ & $27,104.80$ & $25,210.91$ & $24,328.43$ & - \\
\hline 5/4 Size & 40,890 & $4,513.61$ & $4,041.29$ & $3,762.11$ & $3,503.72$ & $3,381.53$ & - \\
\hline $\begin{array}{l}\text { Ties (7" thick x 9" } \\
\text { wide) }\end{array}$ & 1,834 & - & - & - & - & - & 25.27 \\
\hline
\end{tabular}

Table 4.3.16: Specific Energy Consumption of Different Sizes in Sawmill 3-Red Oak

\begin{tabular}{|l|c|c|c|c|c|c|}
\hline \multirow{2}{*}{ Size } & \multicolumn{6}{|c|}{ Specific Energy Consumption (kWh/MBF) } \\
\cline { 2 - 7 } & $\begin{array}{c}\text { 4 inch } \\
\text { Width }\end{array}$ & $\begin{array}{c}\text { 6 inch } \\
\text { Width }\end{array}$ & $\begin{array}{c}\text { 8 inch } \\
\text { Width }\end{array}$ & $\begin{array}{c}\text { 10 inch } \\
\text { Width }\end{array}$ & $\begin{array}{c}\text { 12 inch } \\
\text { Width }\end{array}$ & $\begin{array}{c}\text { 9 inch } \\
\text { Width }\end{array}$ \\
\hline 4/4 Size & 137.64 & 123.24 & 114.70 & 106.69 & 102.95 & \\
\hline 5/4 Size & 110.38 & 98.83 & 92.01 & 85.69 & 82.70 & \\
\hline $\begin{array}{l}\text { Ties (7" thick x 9" } \\
\text { wide }\end{array}$ & - & - & - & - & - & 13.78 \\
\hline
\end{tabular}

As shown in Tables 4.3.11-4.3.16, the energy consumption of Sawmill 1 for 4/4 size lumber varied between $122.68 \sim 156.24$. For Sawmill 2, the energy consumption varied between $86.08 \sim 94.93$ and for Sawmill 3, it varied between $102.95 \sim 137.64$. Sawmill 2 was found to be the most efficient and the comparisons of energy profiles of different sizes among 3 sawmills is shown in Figures 4.3.3, 4.3.4, and 4.3.5. 


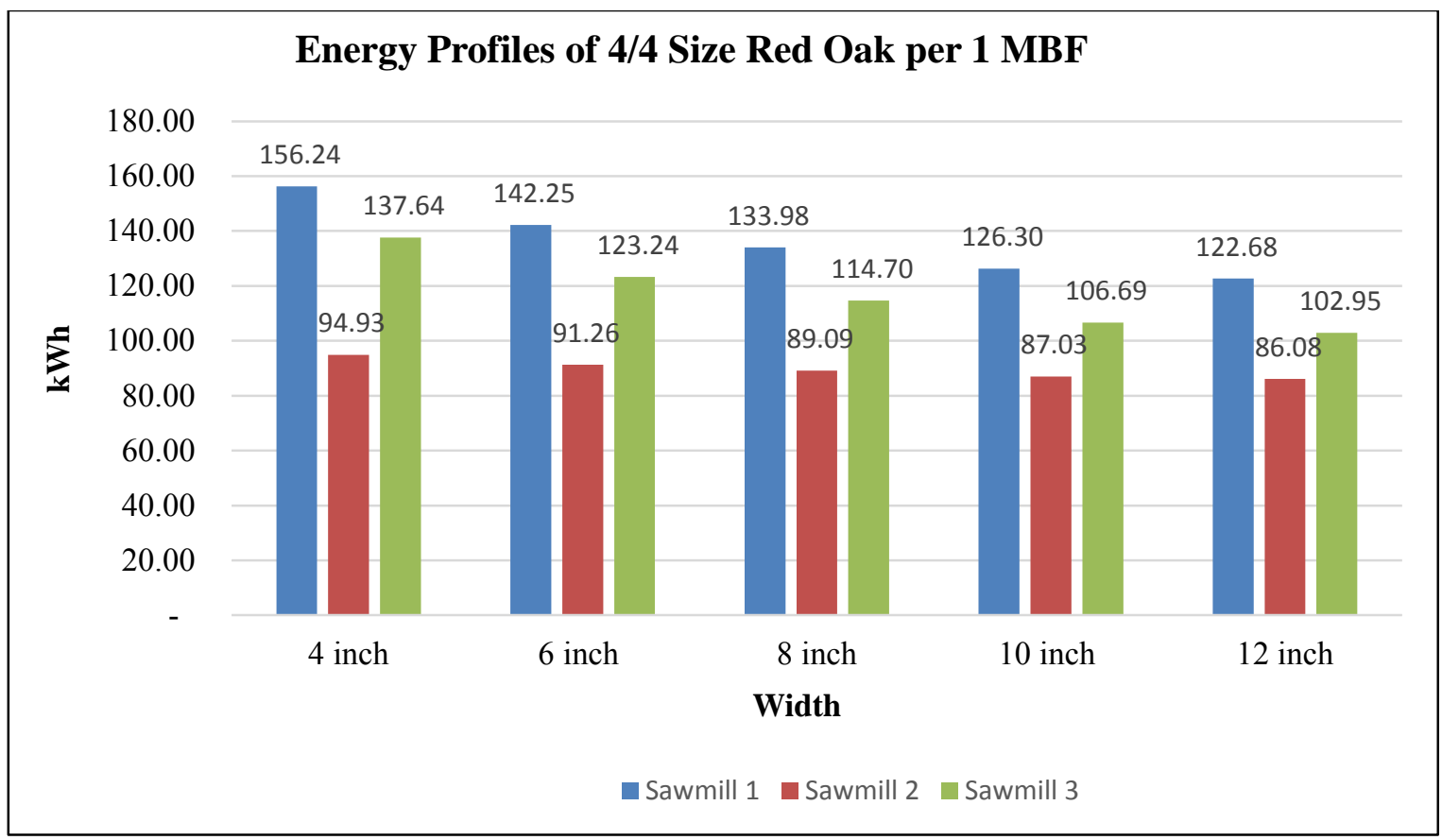

Figure 4.3.3: Energy Profile of 4/4 Size Lumber with Different Widths-Red Oak

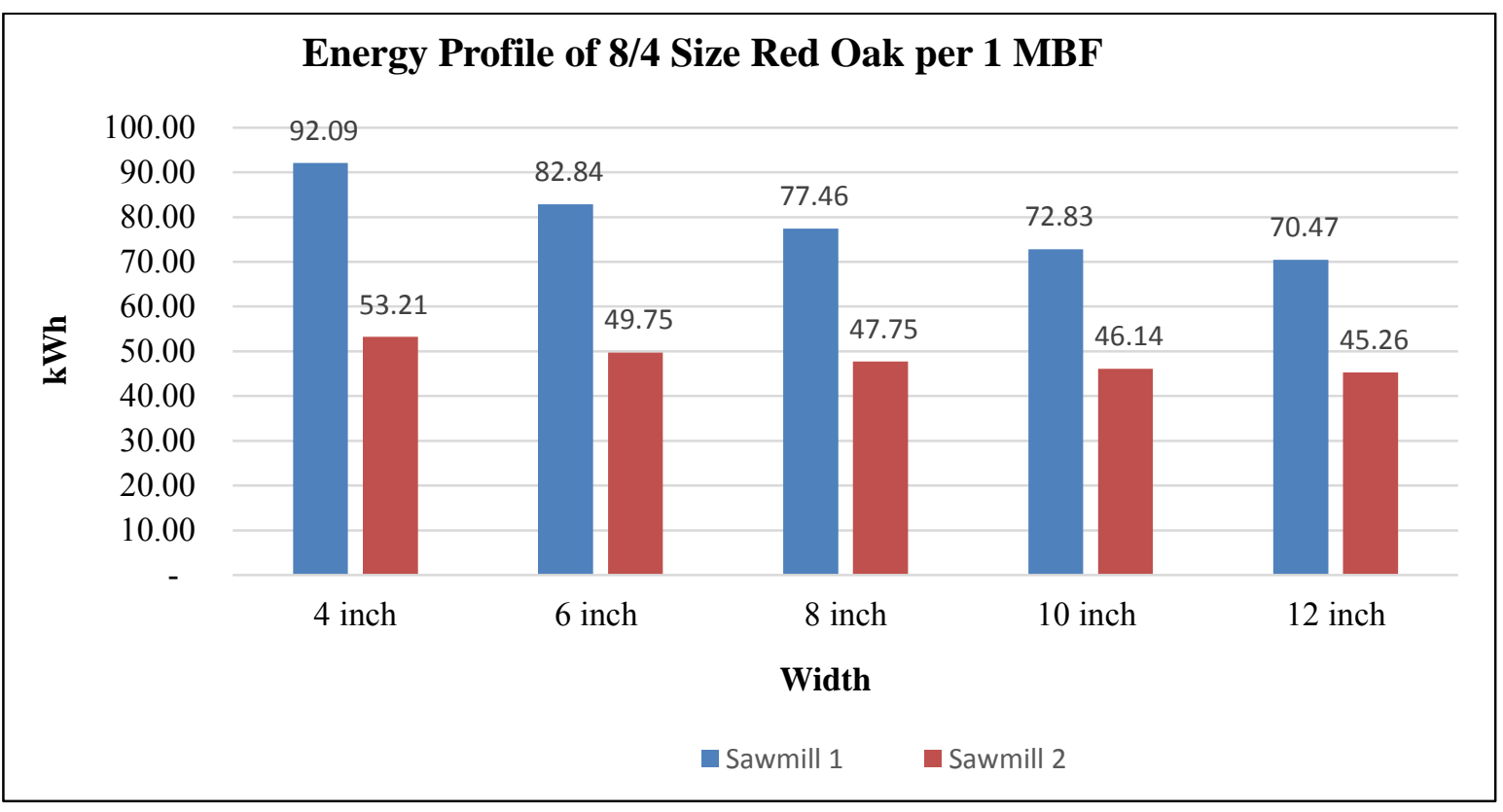

Figure 4.3.4: Energy Profile of 8/4 Size Lumber with Different Widths - Red Oak 


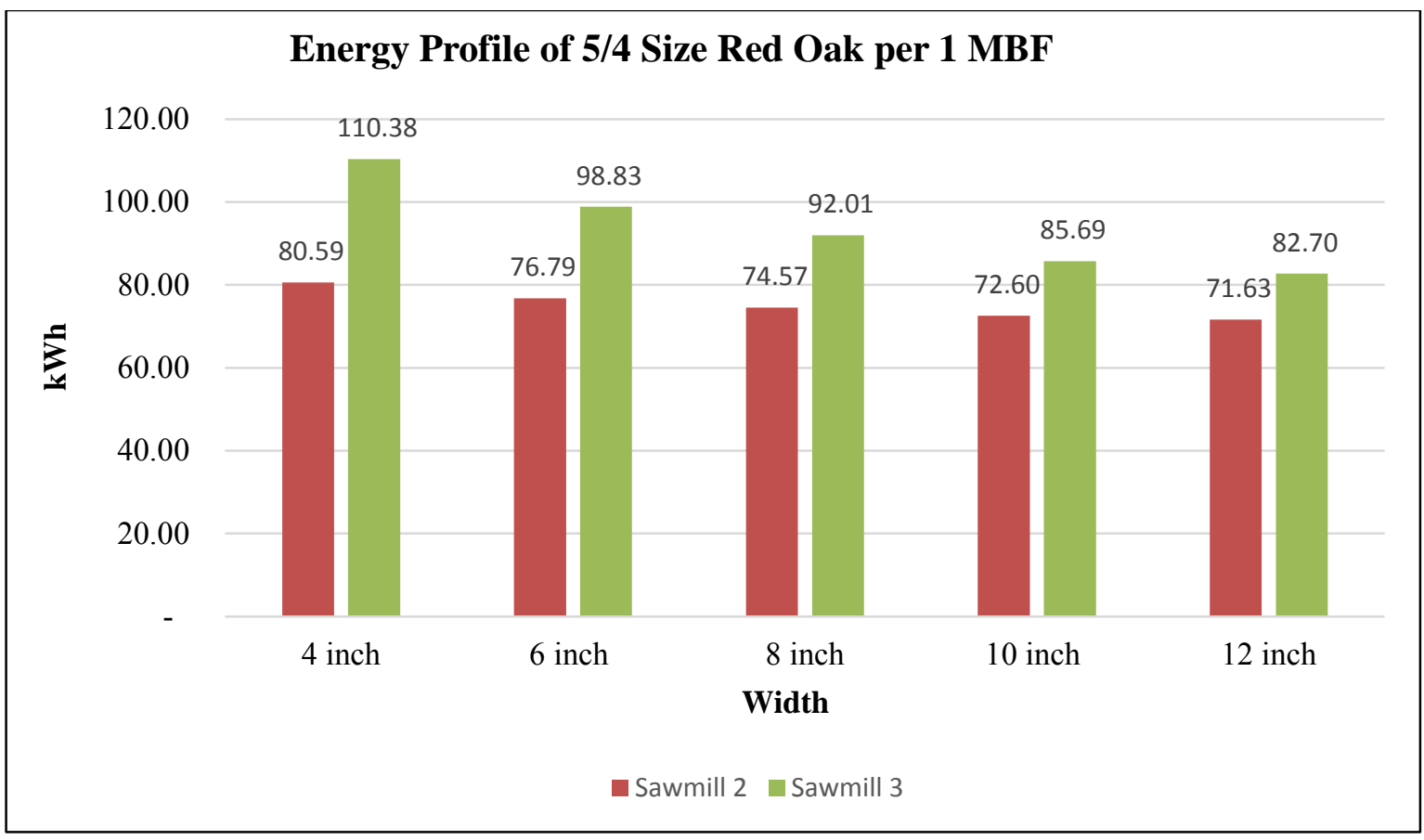

Figure 4.3.5: Energy Profile of 5/4 Size Lumber with Different Widths - Red Oak

White Oak:

After red oak, white oak was the most frequently sawn species in all the 3 sawmills. The total lumber production was 107,427 board feet. Total energy consumption and lumber production for different sizes in each sawmill are shown below.

Table 4.3.17: Total Energy Consumption of Different Sizes in Sawmill 1-White Oak

\begin{tabular}{|l|c|c|c|c|c|c|c|}
\hline \multirow{2}{*}{ Size } & \multirow{2}{*}{ Total BF } & \multicolumn{6}{|c|}{ Energy Consumption (kWh) } \\
\cline { 3 - 8 } & & $\begin{array}{c}\text { 4 inch } \\
\text { Width }\end{array}$ & $\begin{array}{c}\text { 6 inch } \\
\text { Width }\end{array}$ & $\begin{array}{c}\text { 8 inch } \\
\text { Width }\end{array}$ & $\begin{array}{c}\text { 10 inch } \\
\text { Width }\end{array}$ & $\begin{array}{c}\text { 12 inch } \\
\text { Width }\end{array}$ & $\begin{array}{c}\text { 9 inch } \\
\text { Width }\end{array}$ \\
\hline 4/4 Size & 15,306 & $2,681.08$ & $2,442.49$ & $2,301.84$ & $2,173.27$ & $2,111.71$ & - \\
\hline 5/4 Size & 33,066 & $4,931.29$ & $4,493.83$ & $4,235.22$ & $3,995.15$ & $3,882.02$ & - \\
\hline 6/4 Size & 3,828 & 401.36 & 364.17 & 342.36 & 322.92 & 313.37 & - \\
\hline Cants (5" thick) & 20,675 & 568.58 & 529.01 & 504.78 & 478.78 & 468.19 & - \\
\hline $\begin{array}{l}\text { Ties (7" thick x 9" } \\
\text { wide) }\end{array}$ & 31,204 & - & - & - & - & - & 580.17 \\
\hline
\end{tabular}


Table 4.3.18: Specific Energy Consumption of Different Sizes in Sawmill 1-White Oak

\begin{tabular}{|l|c|c|c|c|c|c|}
\hline \multirow{2}{*}{ Size } & \multicolumn{6}{|c|}{ Specific Energy Consumption (kWh/MBF) } \\
\cline { 2 - 8 } & $\begin{array}{c}\text { 4 inch } \\
\text { Width }\end{array}$ & $\begin{array}{c}\text { 6 inch } \\
\text { Width }\end{array}$ & $\begin{array}{c}\text { 8 inch } \\
\text { Width }\end{array}$ & $\begin{array}{c}\text { 10 inch } \\
\text { Width }\end{array}$ & $\begin{array}{c}\text { 12 inch } \\
\text { Width }\end{array}$ & $\begin{array}{c}\text { 9 inch } \\
\text { Width }\end{array}$ \\
\hline 4/4 Size & 175.17 & 159.58 & 150.39 & 141.99 & 137.97 & - \\
\hline 5/4 Size & 149.13 & 135.90 & 128.08 & 120.82 & 117.40 & - \\
\hline 6/4 Size & 104.85 & 95.13 & 89.44 & 84.36 & 81.86 & - \\
\hline Cants (5" thick) & 27.50 & 25.59 & 24.42 & 23.16 & 22.65 & - \\
\hline $\begin{array}{l}\text { Ties (7" thick x 9" } \\
\text { wide) }\end{array}$ & - & - & - & - & - & 18.59 \\
\hline
\end{tabular}

Table 4.3.19: Total Energy Consumption of Different Sizes in Sawmill 2-White Oak

\begin{tabular}{|l|c|c|c|c|c|c|c|}
\hline \multirow{2}{*}{ Size } & \multirow{2}{*}{ Total BF } & \multicolumn{6}{|c|}{ Energy Consumption (kWh) } \\
\cline { 3 - 9 } & & $\begin{array}{c}\text { Width } \\
\text { Winch }\end{array}$ & $\begin{array}{c}\text { 6 inch } \\
\text { Width }\end{array}$ & $\begin{array}{c}\text { 8 inch } \\
\text { Width }\end{array}$ & $\begin{array}{c}\text { 10 inch } \\
\text { Width }\end{array}$ & $\begin{array}{c}\text { 12 inch } \\
\text { Width }\end{array}$ & $\begin{array}{c}\text { 9 inch } \\
\text { Width }\end{array}$ \\
\hline 4/4 Size & 59,442 & $5,830.52$ & $5,595.78$ & $5,456.48$ & $5,324.90$ & $5,263.97$ & - \\
\hline 5/4 Size & 827 & 66.39 & 63.34 & 61.56 & 59.99 & 59.21 & - \\
\hline 6/4 Size & 7,618 & 580.91 & 548.77 & 530.09 & 514.33 & 506.13 & - \\
\hline Cants (3" thick) & 1,659 & 42.63 & 42.73 & 42.71 & 42.30 & 42.29 & - \\
\hline $\begin{array}{l}\text { Ties (7" thick x 9" } \\
\text { wide) }\end{array}$ & 2,800 & - & - & - & - & - & 30.51 \\
\hline
\end{tabular}

Table 4.3.20: Specific Energy Consumption of Different Sizes in Sawmill 2-White Oak

\begin{tabular}{|l|c|c|c|c|c|c|}
\hline \multirow{2}{*}{ Size } & \multicolumn{5}{|c|}{ Specific Energy Consumption (kWh/MBF) } \\
\cline { 2 - 8 } & $\begin{array}{c}\text { 4 inch } \\
\text { Width }\end{array}$ & $\begin{array}{c}\text { 6 inch } \\
\text { Width }\end{array}$ & $\begin{array}{c}\text { 8 inch } \\
\text { Width }\end{array}$ & $\begin{array}{c}\text { 10 inch } \\
\text { Width }\end{array}$ & $\begin{array}{c}\text { 12 inch } \\
\text { Width }\end{array}$ & $\begin{array}{c}\text { 9 inch } \\
\text { Width }\end{array}$ \\
\hline 4/4 Size & 98.09 & 94.14 & 91.79 & 89.58 & 88.56 & - \\
\hline 5/4 Size & 80.28 & 76.59 & 74.44 & 72.54 & 71.60 & - \\
\hline 6/4 Size & 76.25 & 72.04 & 69.58 & 67.51 & 66.44 & - \\
\hline Cants (3" thick) & 25.69 & 25.76 & 25.74 & 25.50 & 25.49 & - \\
\hline $\begin{array}{l}\text { Ties (7" thick x 9" } \\
\text { wide) }\end{array}$ & - & - & - & - & - & 10.90 \\
\hline
\end{tabular}


Table 4.3.21: Total Energy Consumption of Different Sizes in Sawmill 3-White Oak

\begin{tabular}{|l|c|c|c|c|c|c|c|}
\hline \multirow{2}{*}{ Size } & \multirow{2}{*}{ Total BF } & \multicolumn{6}{|c|}{ Energy Consumption (kWh) } \\
\cline { 3 - 8 } & $\begin{array}{c}\text { 4inch } \\
\text { Width }\end{array}$ & $\begin{array}{c}\text { 6 inch } \\
\text { Width }\end{array}$ & $\begin{array}{c}\text { 8 inch } \\
\text { Width }\end{array}$ & $\begin{array}{c}\text { 10 inch } \\
\text { Width }\end{array}$ & $\begin{array}{c}\text { 12 inch } \\
\text { Width }\end{array}$ & $\begin{array}{c}\text { 9 inch } \\
\text { Width }\end{array}$ \\
\hline 5/4 Size & 827 & 66.39 & 63.34 & 61.56 & 59.99 & 59.21 & - \\
\hline Cants (3.5" thick) & 1,659 & 42.63 & 42.73 & 42.71 & 42.30 & 42.29 & - \\
\hline $\begin{array}{l}\text { Ties (7" thick x 9" } \\
\text { wide) }\end{array}$ & 2,800 & - & - & - & - & - & 30.51 \\
\hline
\end{tabular}

Table 4.3.22: Specific Energy Consumption of Different Sizes in Sawmill 3-White Oak

\begin{tabular}{|l|c|c|c|c|c|c|}
\hline \multirow{2}{*}{ Size } & \multicolumn{5}{|c|}{ Specific Energy Consumption (kWh/MBF) } \\
\cline { 2 - 7 } & $\begin{array}{c}\text { 4 inch } \\
\text { Width }\end{array}$ & $\begin{array}{c}\text { 6 inch } \\
\text { Width }\end{array}$ & $\begin{array}{c}\text { 8 inch } \\
\text { Width }\end{array}$ & $\begin{array}{c}\text { 10 inch } \\
\text { Width }\end{array}$ & $\begin{array}{c}\text { 12 inch } \\
\text { Width }\end{array}$ & $\begin{array}{c}\text { 9 inch } \\
\text { Width }\end{array}$ \\
\hline 5/4 Size & 160.74 & 144.30 & 134.57 & 125.47 & 121.21 & - \\
\hline Cants (3.5" thick) & 47.68 & 42.83 & 39.92 & 36.94 & 35.67 & - \\
\hline $\begin{array}{l}\text { Ties (7" thick x 9" } \\
\text { wide) }\end{array}$ & - & - & - & - & - & 20.41 \\
\hline
\end{tabular}

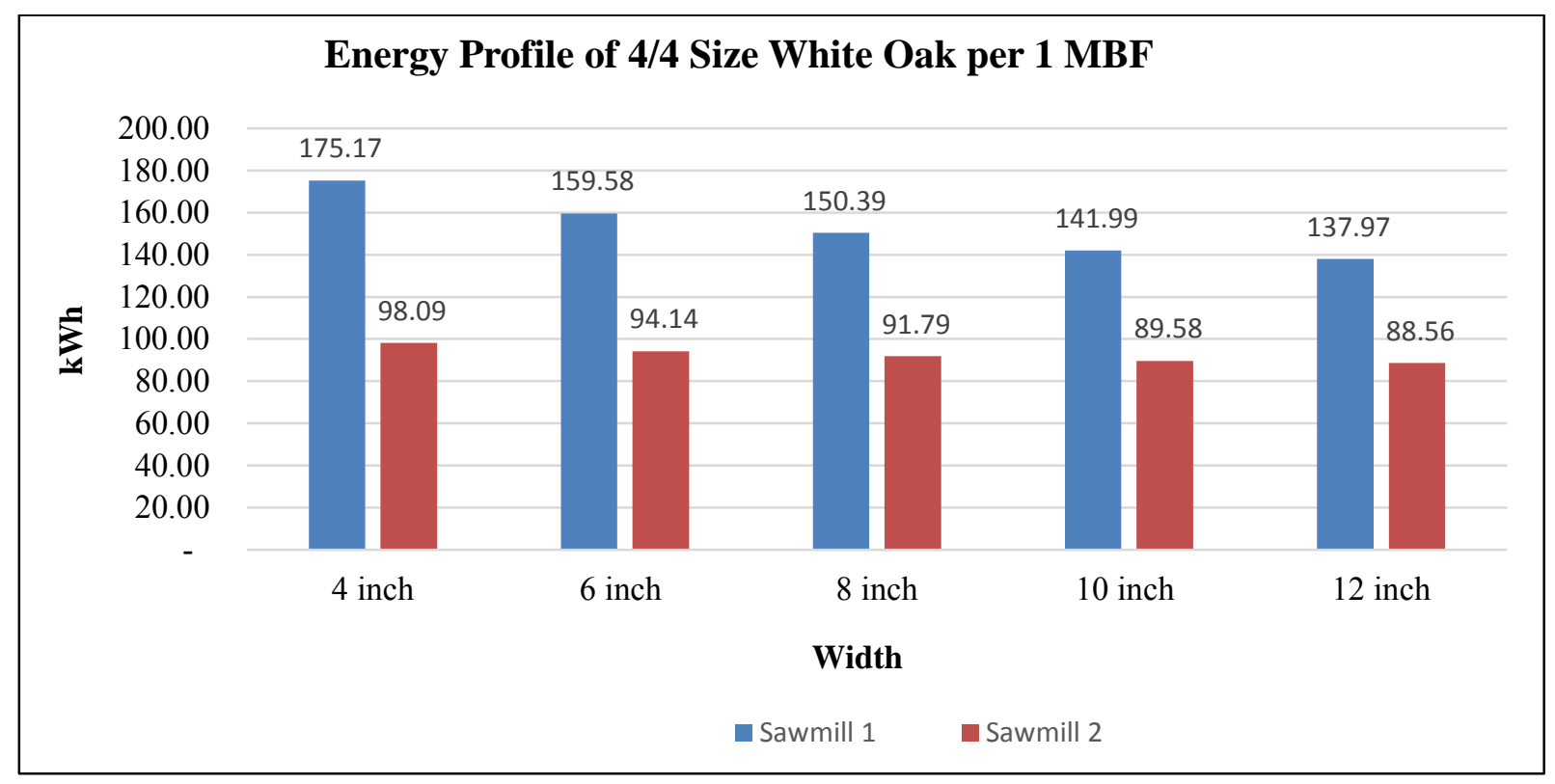

Figure 4.3.6: Energy Profile of 4/4 Size Lumber with Different Widths - White Oak 


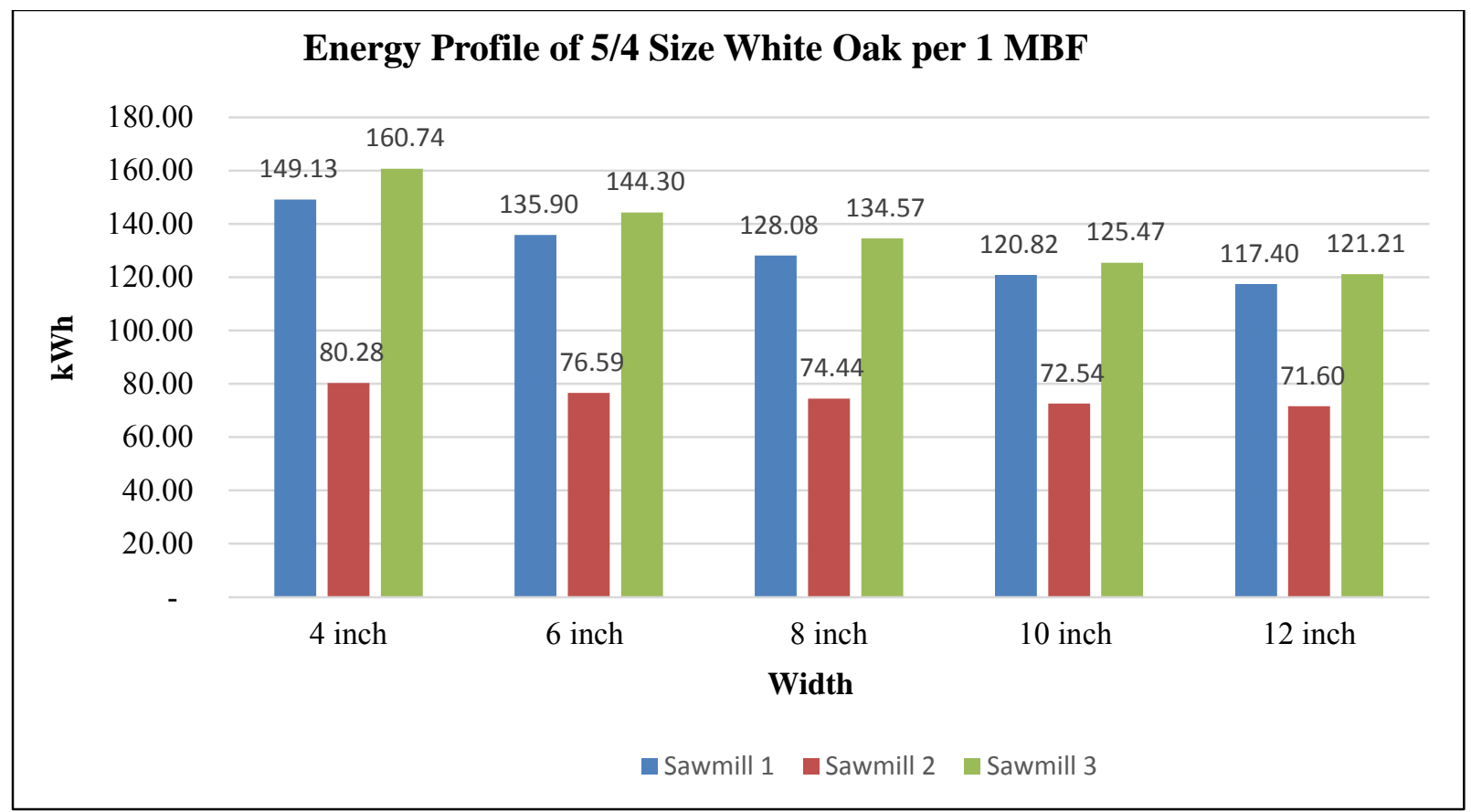

Figure 4.3.7: Energy Profile of 5/4 Size Lumber with Different Widths - White Oak

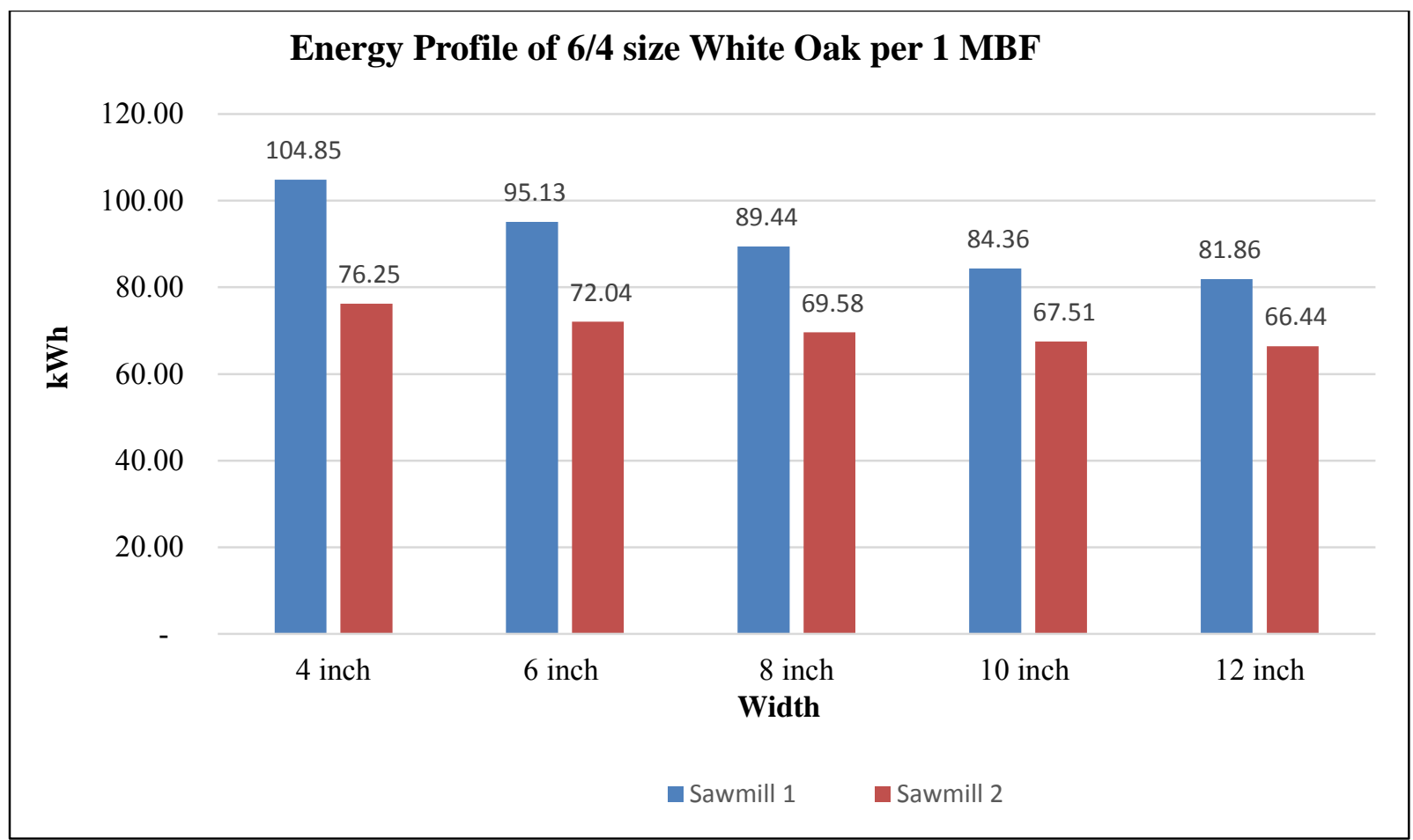

Figure 4.3.8: Energy Profile of 6/4 Size Lumber with Different Widths - White Oak 


\section{Poplar:}

Poplar was produced in Sawmill 1 and Sawmill 3. The comparison of energy consumption of different sizes in each sawmill is shown in Table 4.3.23 and 4.3.24.

Table 4.3.23: Total Energy Consumption of Different Sizes in Sawmill 1-Poplar

\begin{tabular}{|l|c|c|c|c|c|c|c|}
\hline \multirow{2}{*}{ Size } & \multirow{2}{*}{ Total BF } & \multicolumn{6}{|c|}{ Energy Consumption (kWh) } \\
\cline { 3 - 8 } & & $\begin{array}{c}\text { 4 inch } \\
\text { Width }\end{array}$ & $\begin{array}{c}\text { 6 inch } \\
\text { Width }\end{array}$ & $\begin{array}{c}\text { 8 inch } \\
\text { Width }\end{array}$ & $\begin{array}{c}\text { 10 inch } \\
\text { Width }\end{array}$ & $\begin{array}{c}\text { 12 inch } \\
\text { Width }\end{array}$ & $\begin{array}{c}\text { 9 inch } \\
\text { Width }\end{array}$ \\
\hline 4/4 Size & 6,689 & 914.45 & 832.29 & 783.78 & 738.97 & 717.75 & - \\
\hline 6/4 Size & 8,456 & 870.18 & 787.68 & 739.35 & 696.29 & 675.15 & - \\
\hline 8/4 Size & 1,074 & 87.13 & 78.35 & 73.25 & 68.90 & 66.67 & - \\
\hline Cants (5" thick) & 8,180 & 182.13 & 168.85 & 160.73 & 152.13 & 148.57 & \\
\hline Cants (3" thick) & 9,326 & 364.87 & 338.05 & 321.66 & 304.29 & 297.12 & - \\
\hline $\begin{array}{l}\text { Ties (7" thick x 9" } \\
\text { wide) }\end{array}$ & 4,506 & - & - & - & - & - & 66.67 \\
\hline
\end{tabular}

Table 4.3.24: Specific Energy Consumption of Different Sizes in Sawmill 1-Poplar

\begin{tabular}{|l|c|c|c|c|c|c|}
\hline \multirow{2}{*}{ Size } & \multicolumn{5}{|c|}{ Specific Energy Consumption (kWh/MBF) } \\
\cline { 2 - 8 } & $\begin{array}{c}\mathbf{4} \text { inch } \\
\text { Width }\end{array}$ & $\begin{array}{c}\text { 6 inch } \\
\text { Width }\end{array}$ & $\begin{array}{c}\mathbf{8} \text { inch } \\
\text { Width }\end{array}$ & $\begin{array}{c}\mathbf{1 0} \text { inch } \\
\text { Width }\end{array}$ & $\begin{array}{c}\text { 12 inch } \\
\text { Width }\end{array}$ & $\begin{array}{c}\text { 9 inch } \\
\text { Width }\end{array}$ \\
\hline 4/4 Size & 136.71 & 124.43 & 117.17 & 110.48 & 107.30 & - \\
\hline 6/4 Size & 102.91 & 93.15 & 87.44 & 82.34 & 79.84 & - \\
\hline 8/4 Size & 81.13 & 72.95 & 68.21 & 64.15 & 62.08 & - \\
\hline Cants (5" thick) & 22.27 & 20.64 & 19.65 & 18.60 & 18.16 & \\
\hline Cants (3" thick) & 39.12 & 36.25 & 34.49 & 32.63 & 31.86 & - \\
\hline $\begin{array}{l}\text { Ties (7" thick x 9" } \\
\text { wide) }\end{array}$ & - & - & - & - & - & 14.80 \\
\hline
\end{tabular}

Table 4.3.25: Total Energy Consumption of Different Sizes in Sawmill 3-Poplar

\begin{tabular}{|l|c|c|c|c|c|c|}
\hline \multirow{2}{*}{ Size } & \multirow{2}{*}{ Total BF } & \multicolumn{5}{|c|}{ Energy Consumption (kWh) } \\
\cline { 3 - 7 } & & $\begin{array}{c}\text { 4 inch } \\
\text { Width }\end{array}$ & $\begin{array}{c}\text { 6 inch } \\
\text { Width }\end{array}$ & $\begin{array}{c}\text { 8 inch } \\
\text { Width }\end{array}$ & $\begin{array}{c}\text { 10 inch } \\
\text { Width }\end{array}$ & $\begin{array}{c}\text { 12 inch } \\
\text { Width }\end{array}$ \\
\hline 4/4 Size & 130,899 & $13,173.46$ & $11,780.47$ & $10,954.68$ & $10,179.04$ & $9,817.79$ \\
\hline $8 / 4$ Size & 29,543 & $1,740.81$ & $1,556.66$ & $1,448.57$ & $1,352.11$ & $1,304.75$ \\
\hline Cants (3.5" thick) & 32,318 & 743.23 & 664.34 & 616.86 & 568.98 & 548.25 \\
\hline
\end{tabular}


Table 4.3.26: Specific Energy Consumption of Different Sizes in Sawmill 3-Poplar

\begin{tabular}{|l|c|c|c|c|c|}
\hline \multirow{2}{*}{\multicolumn{1}{|c|}{ Size }} & \multicolumn{5}{|c|}{ Specific Energy Consumption (kWh/MBF) } \\
\cline { 2 - 6 } & $\begin{array}{c}\text { 4 inch } \\
\text { Width }\end{array}$ & $\begin{array}{c}\text { 6 inch } \\
\text { Width }\end{array}$ & $\begin{array}{c}\text { 8 inch } \\
\text { Width }\end{array}$ & $\begin{array}{c}\text { 10 inch } \\
\text { Width }\end{array}$ & $\begin{array}{c}\text { 12 inch } \\
\text { Width }\end{array}$ \\
\hline 4/4 Size & 100.64 & 90.00 & 83.69 & 77.76 & 75.00 \\
\hline 8/4 Size & 58.92 & 52.69 & 49.03 & 45.77 & 44.16 \\
\hline Cants (3.5" thick) & 23.00 & 20.56 & 19.09 & 17.61 & 16.96 \\
\hline
\end{tabular}

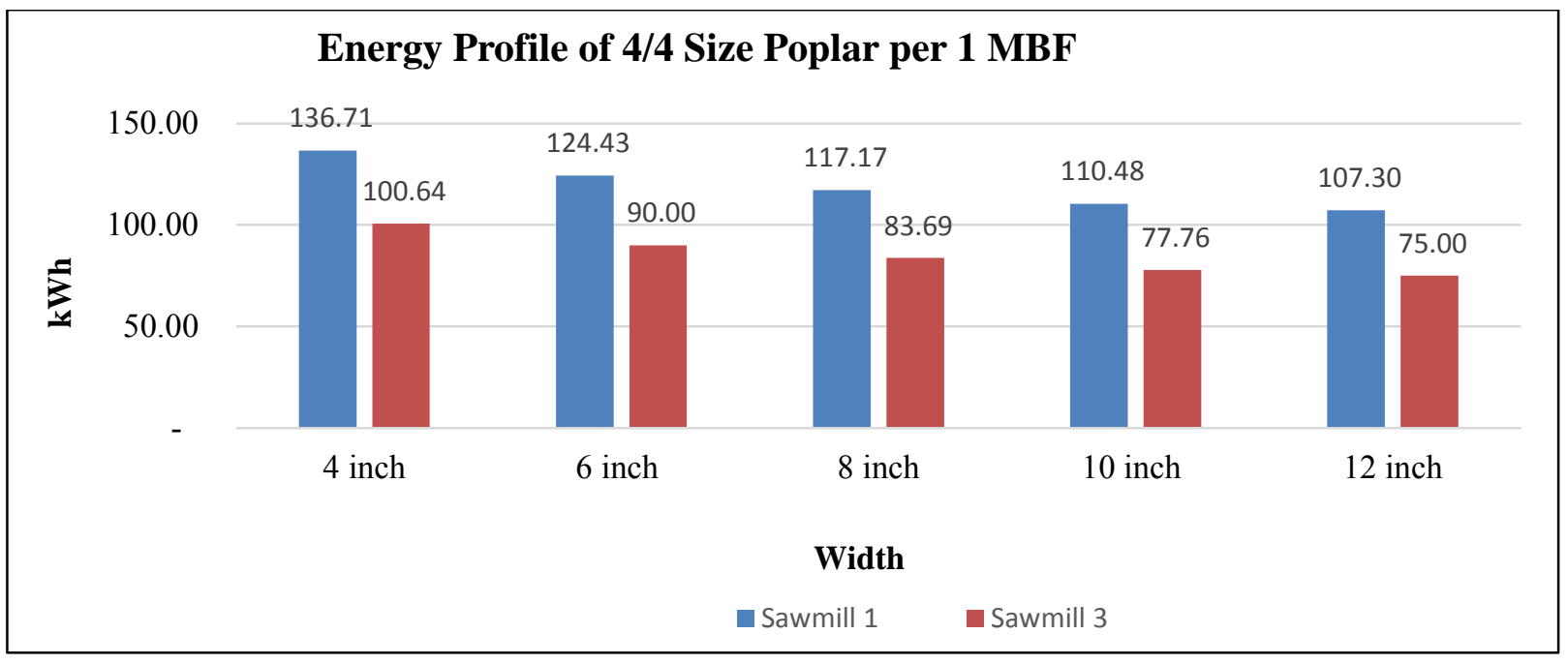

Figure 4.3.9: Energy Profile of 4/4 Size Lumber with Different Widths - Poplar

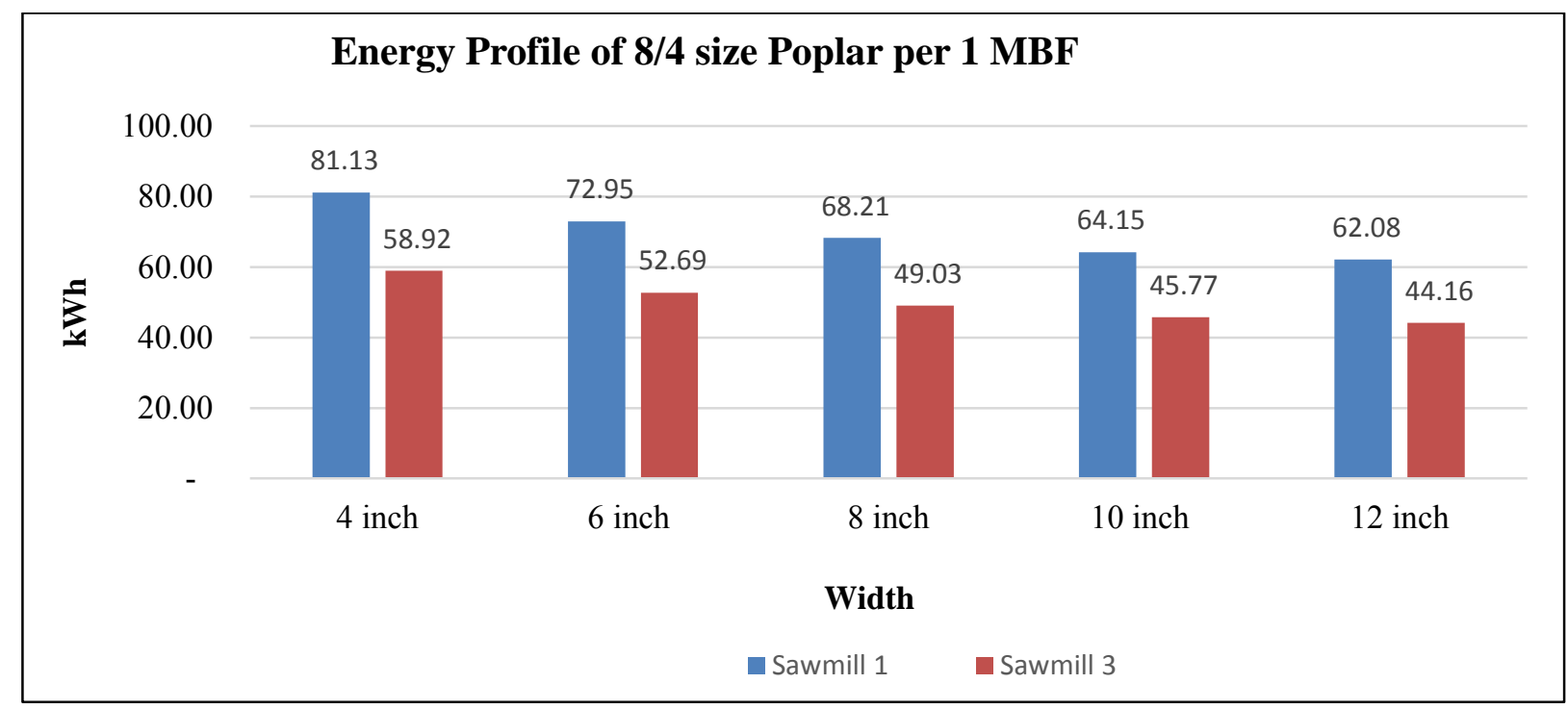

Figure 4.3.10: Energy Profile of 4/4 Size Lumber with Different Widths - Poplar 
Ash:

Ash was produced in Sawmill 2 and Sawmill 3. The total lumber production of different sizes from both sawmills was 235,142 board feet. The energy consumption for individual sizes is shown below.

Table 4.3.27: Total Energy Consumption of Different Sizes in Sawmill 2-Ash

\begin{tabular}{|l|c|c|c|c|c|c|c|}
\hline \multirow{2}{*}{ Size } & \multirow{2}{*}{ Total BF } & \multicolumn{7}{|c|}{ Energy Consumption (kWh) } \\
\cline { 3 - 8 } & & $\begin{array}{c}\text { 4 inch } \\
\text { Width }\end{array}$ & $\begin{array}{c}\text { 6 inch } \\
\text { Width }\end{array}$ & $\begin{array}{c}\text { 8 inch } \\
\text { Width }\end{array}$ & $\begin{array}{c}\text { 10 inch } \\
\text { Width }\end{array}$ & $\begin{array}{c}\text { 12 inch } \\
\text { Width }\end{array}$ & $\begin{array}{c}\text { 9 inch } \\
\text { Width }\end{array}$ \\
\hline 4/4 Size & 12,053 & $1,047.51$ & $1,003.48$ & 977.43 & 953.17 & 941.77 & - \\
\hline Cants (3" thick) & 792 & 18.73 & 18.79 & 18.78 & 18.61 & 18.60 & - \\
\hline $\begin{array}{l}\text { Ties (7" thick x 9" } \\
\text { wide) }\end{array}$ & 40 & - & - & - & - & - & 0.41 \\
\hline
\end{tabular}

Table 4.3.28: Specific Energy Consumption of Different Sizes in Sawmill 2-Ash

\begin{tabular}{|l|c|c|c|c|c|c|}
\hline \multirow{2}{*}{ Size } & \multicolumn{6}{|c|}{ Specific Energy Consumption (kWh/MBF) } \\
\cline { 2 - 7 } & $\begin{array}{c}\text { 4 inch } \\
\text { Width }\end{array}$ & $\begin{array}{c}\text { 6 inch } \\
\text { Width }\end{array}$ & $\begin{array}{c}\text { 8 inch } \\
\text { Width }\end{array}$ & $\begin{array}{c}\text { 10 inch } \\
\text { Width }\end{array}$ & $\begin{array}{c}\text { 12 inch } \\
\text { Width }\end{array}$ & $\begin{array}{c}\text { 9 inch } \\
\text { Width }\end{array}$ \\
\hline 4/4 Size & 86.91 & 83.26 & 81.09 & 79.08 & 78.14 & - \\
\hline Cants (3" thick) & 23.65 & 23.72 & 23.71 & 23.49 & 23.49 & - \\
\hline $\begin{array}{l}\text { Ties (7" thick x 9" } \\
\text { wide) }\end{array}$ & - & - & - & - & - & 10.17 \\
\hline
\end{tabular}

Table 4.3.29: Total Energy Consumption of Different Sizes in Sawmill 3-Ash

\begin{tabular}{|l|c|c|c|c|c|c|}
\hline \multirow{2}{*}{ Size } & \multirow{2}{*}{ Total BF } & \multicolumn{5}{|c|}{ Energy Consumption (kWh) } \\
\cline { 3 - 8 } & $\begin{array}{c}\text { 4 inch } \\
\text { Width }\end{array}$ & $\begin{array}{c}\text { 6 inch } \\
\text { Width }\end{array}$ & $\begin{array}{c}\text { 8 inch } \\
\text { Width }\end{array}$ & $\begin{array}{c}\text { 10 inch } \\
\text { Width }\end{array}$ & $\begin{array}{c}\text { 12 inch } \\
\text { Width }\end{array}$ \\
\hline 4/4 Size & 29,710 & $3,572.54$ & $3,188.59$ & $2,960.91$ & $2,746.64$ & $2,647.04$ \\
\hline 8/4 Size & 4,486 & 321.95 & 287.39 & 267.09 & 248.92 & 240.03 \\
\hline
\end{tabular}

Table 4.3.30: Specific Energy Consumption of Different Sizes in Sawmill 3-Ash

\begin{tabular}{|l|c|c|c|c|c|}
\hline \multirow{2}{*}{ Size } & \multicolumn{5}{|c|}{ Specific Energy Consumption (kWh/MBF) } \\
\cline { 2 - 7 } & $\begin{array}{c}\text { 4 inch } \\
\text { Width }\end{array}$ & $\begin{array}{c}\text { 6 inch } \\
\text { Width }\end{array}$ & $\begin{array}{c}\text { 8 inch } \\
\text { Width }\end{array}$ & $\begin{array}{c}\text { 10 inch } \\
\text { Width }\end{array}$ & $\begin{array}{c}\text { 12 inch } \\
\text { Width }\end{array}$ \\
\hline 4/4 Size & 120.25 & 107.32 & 99.66 & 92.45 & 89.10 \\
\hline 8/4 Size & 71.77 & 64.06 & 59.54 & 55.49 & 53.51 \\
\hline
\end{tabular}




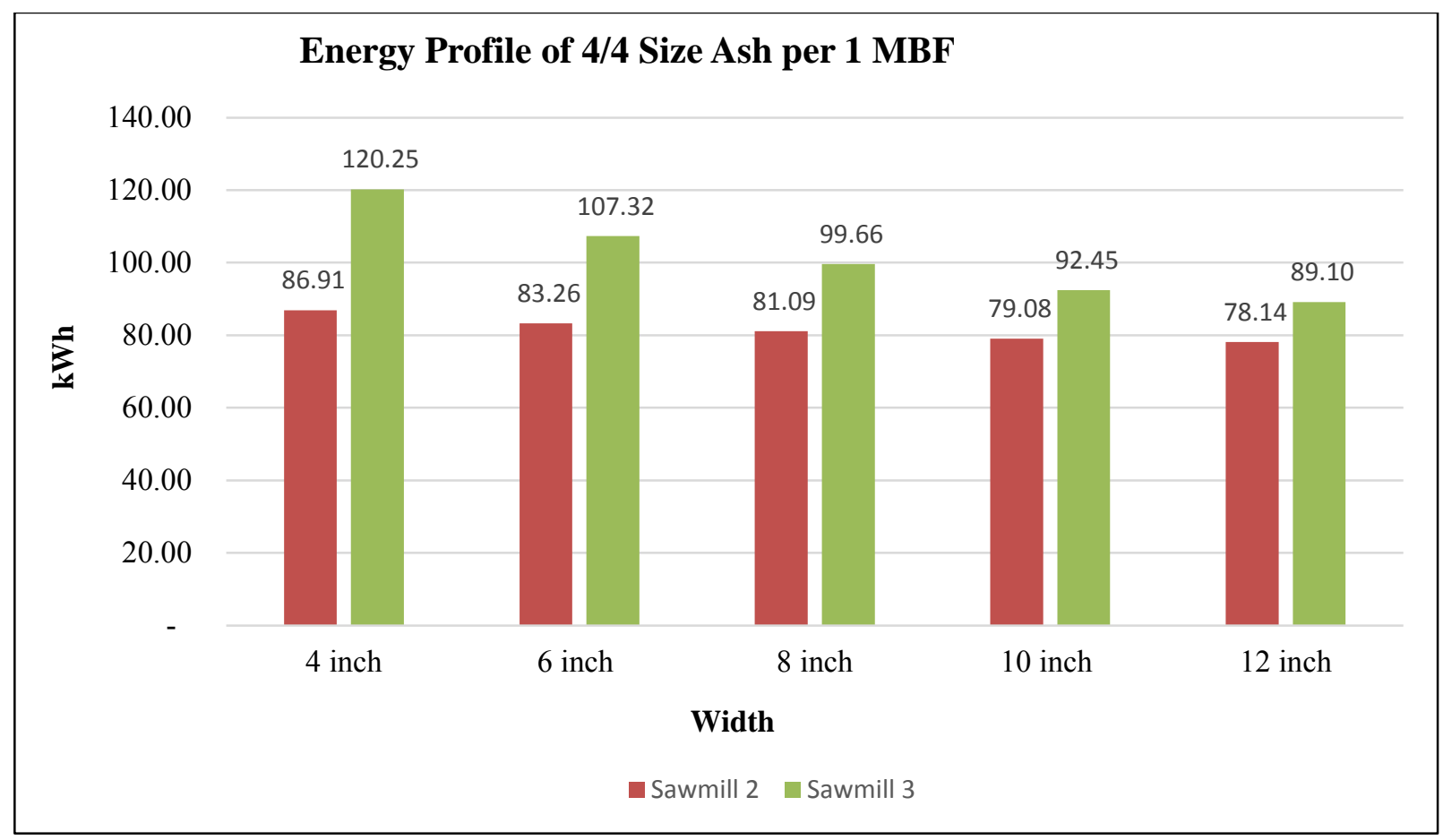

Figure 4.3.11: Energy Profile of 4/4 Size Lumber with Different Widths - Ash

The specific energy consumption of 4/4 inch size ash lumber for Sawmill 2 varied between 78.14 $\mathrm{kWh} \sim 86.91$ whereas for Sawmill 3, specific energy consumption varied between 89.10 120.25.

\section{Soft Maple:}

All 3 sawmills produced soft maple. A total of 226,628 board feet of soft maple lumber was produced from 3 sawmills. During soft maple production, Sawmill 1 had maintenance issues and accurate electrical data of motors were not obtained and hence was excluded from the analysis. Total energy consumption and lumber production for different sizes in Sawmill 2 and Sawmill 3 are shown below.

Table 4.3.30: Total Energy Consumption of Different Sizes in Sawmill 2-Soft Maple

\begin{tabular}{|l|c|c|c|c|c|c|c|}
\hline \multirow{2}{*}{ Size } & \multirow{2}{*}{ Total BF } & \multicolumn{6}{|c|}{ Energy Consumption (kWh) } \\
\cline { 3 - 9 } & $\begin{array}{c}\text { 4 inch } \\
\text { Width }\end{array}$ & $\begin{array}{c}\text { 6 inch } \\
\text { Width }\end{array}$ & $\begin{array}{c}\text { 8 inch } \\
\text { Width }\end{array}$ & $\begin{array}{c}\text { 10 inch } \\
\text { Width }\end{array}$ & $\begin{array}{c}\text { 12 inch } \\
\text { Width }\end{array}$ & $\begin{array}{c}\text { 9 inch } \\
\text { Width }\end{array}$ \\
\hline 4/4 Size & 56,759 & $4,669.76$ & $4,479.17$ & $4,366.37$ & $4,261.21$ & $4,211.86$ & - \\
\hline Cants (3" thick) & 2,784 & 61.66 & 61.91 & 61.93 & 61.40 & 61.41 & - \\
\hline $\begin{array}{l}\text { Ties (7" thick x 9" } \\
\text { wide) }\end{array}$ & 920 & - & - & - & - & - & 8.40 \\
\hline
\end{tabular}


Table 4.3.31: Specific Energy Consumption of Different Sizes in Sawmill 2-Soft Maple

\begin{tabular}{|l|c|c|c|c|c|c|}
\hline \multirow{2}{*}{ Size } & \multicolumn{5}{|c|}{ Specific Energy Consumption (kWh/MBF) } \\
\cline { 2 - 7 } & $\begin{array}{c}\text { 4 inch } \\
\text { Width }\end{array}$ & $\begin{array}{c}\text { 6 inch } \\
\text { Width }\end{array}$ & $\begin{array}{c}\text { 8 inch } \\
\text { Width }\end{array}$ & $\begin{array}{c}\text { 10 inch } \\
\text { Width }\end{array}$ & $\begin{array}{c}\text { 12 inch } \\
\text { Width }\end{array}$ & $\begin{array}{c}\text { 9 inch } \\
\text { Width }\end{array}$ \\
\hline 4/4 Size & 82.27 & 78.92 & 76.93 & 75.08 & 74.21 & - \\
\hline Cants (3" thick) & 22.15 & 22.24 & 22.25 & 22.05 & 22.06 & - \\
\hline $\begin{array}{l}\text { Ties (7" thick x 9" } \\
\text { wide) }\end{array}$ & - & - & - & - & - & 9.13 \\
\hline
\end{tabular}

Table 4.3.32: Total Energy Consumption of Different Sizes in Sawmill 3-Soft Maple

\begin{tabular}{|l|c|c|c|c|c|c|}
\hline \multirow{2}{*}{ Size } & \multirow{2}{*}{ Total BF } & \multicolumn{5}{|c|}{ Energy Consumption (kWh) } \\
\cline { 3 - 7 } & & $\begin{array}{c}\text { 4 inch } \\
\text { Width }\end{array}$ & $\begin{array}{c}\text { 6 inch } \\
\text { Width }\end{array}$ & $\begin{array}{c}\text { 8 inch } \\
\text { Width }\end{array}$ & $\begin{array}{c}\text { 10 inch } \\
\text { Width }\end{array}$ & $\begin{array}{c}\text { 12 inch } \\
\text { Width }\end{array}$ \\
\hline 4/4 Size & 96,603 & $14,325.99$ & $12,846.83$ & $11,971.22$ & $11,154.15$ & $10,771.08$ \\
\hline Cants (3.5" thick) & 28,731 & 953.22 & 853.59 & 793.54 & 733.14 & 706.86 \\
\hline
\end{tabular}

Table 4.3.33: Specific Energy Consumption of Different Sizes in Sawmill 3-Soft Maple

\begin{tabular}{|l|c|c|c|c|c|}
\hline \multirow{2}{*}{\multicolumn{1}{|c|}{ Size }} & \multicolumn{5}{|c|}{ Specific Energy Consumption (kWh/MBF) } \\
\cline { 2 - 6 } & $\begin{array}{c}\text { 4 inch } \\
\text { Width }\end{array}$ & $\begin{array}{c}\text { 6 inch } \\
\text { Width }\end{array}$ & $\begin{array}{c}\text { 8 inch } \\
\text { Width }\end{array}$ & $\begin{array}{c}\text { 10 inch } \\
\text { Width }\end{array}$ & $\begin{array}{c}\text { 12 inch } \\
\text { Width }\end{array}$ \\
\hline 4/4 Size & 148.30 & 132.99 & 123.92 & 115.46 & 111.50 \\
\hline Cants (3" thick) & 33.18 & 29.71 & 27.62 & 25.52 & 24.60 \\
\hline
\end{tabular}

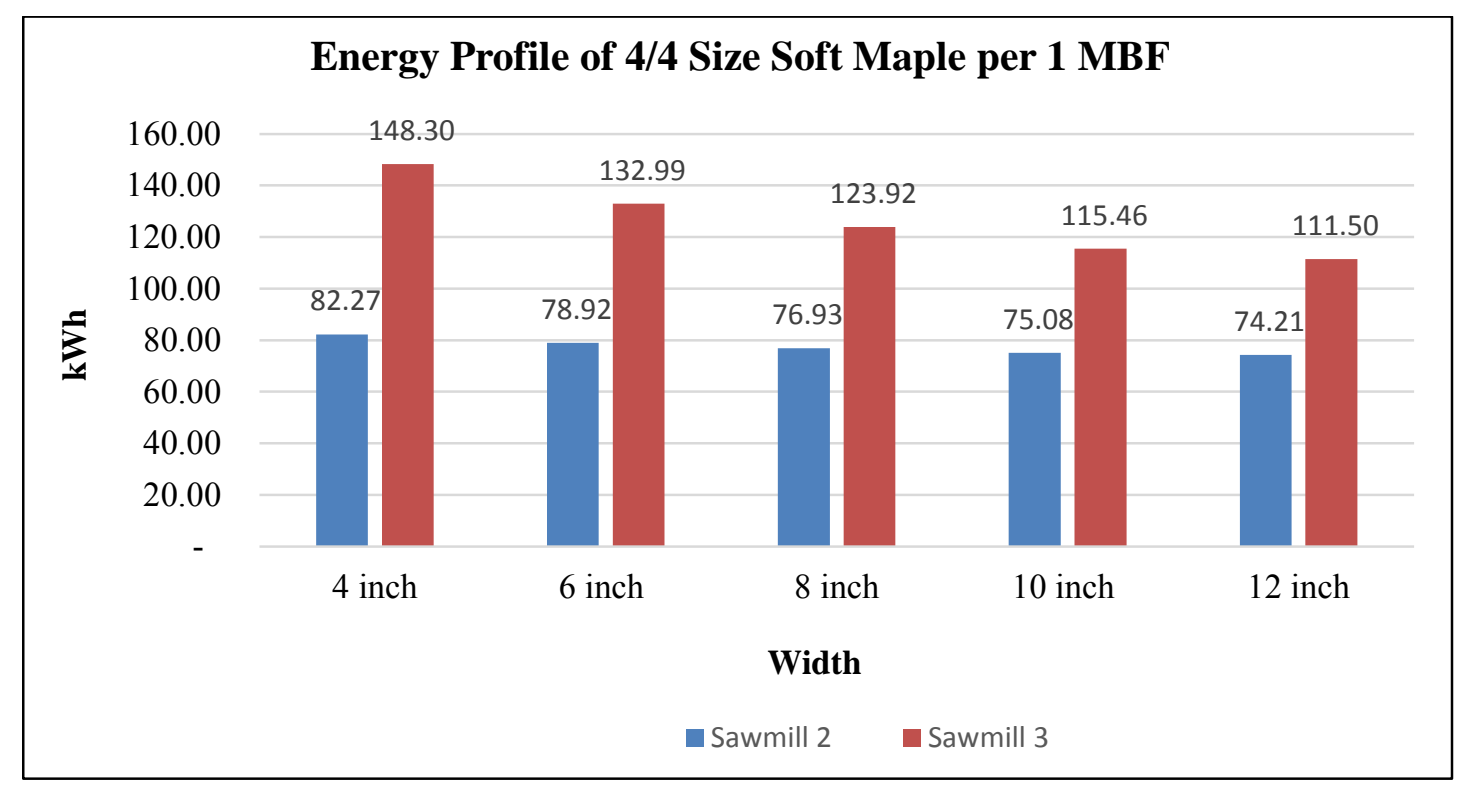

Figure 4.3.12: Energy Profile of 4/4 Size Lumber with Different Widths - Soft Maple 


\section{Cherry:}

Cherry was produced only in Sawmill 2. Sawmill 2 produced 40,250 board feet cherry lumber of different sizes during data logging period. Cherry is considered as soft hardwood and one of the most valuable hardwood lumber in the US market during the study period. Due to the cost of this lumber, it is necessary for sawmills to reduce the wastage produced during sawing of these logs. Operating time of the motors is more than other species during processing of cherry logs due to slow sawing operation. Due to the same reason, specific energy consumption of the cherry lumber was higher than other species in Sawmill 2. The total energy consumption of different size lumber sawn in Sawmill 2 is shown below.

Table 4.3.34: Total Energy Consumption of Different Sizes in Sawmill 2-Cherry

\begin{tabular}{|l|c|c|c|c|c|c|c|}
\hline \multirow{2}{*}{ Size } & \multirow{2}{*}{ Total BF } & \multicolumn{7}{|c|}{ Energy Consumption (kWh) } \\
\cline { 3 - 8 } & & $\begin{array}{c}\text { 4 inch } \\
\text { Width }\end{array}$ & $\begin{array}{c}\text { 6 inch } \\
\text { Width }\end{array}$ & $\begin{array}{c}\text { 8 inch } \\
\text { Width }\end{array}$ & $\begin{array}{c}\text { 10 inch } \\
\text { Width }\end{array}$ & $\begin{array}{c}\text { 12 inch } \\
\text { Width }\end{array}$ & $\begin{array}{c}\text { 9 inch } \\
\text { Width }\end{array}$ \\
\hline 4/4 Size & 23,426 & $2,932.60$ & $2,806.44$ & $2,731.99$ & $2,679.47$ & $2,667.28$ & - \\
\hline Cants (3" thick) & 3,912 & 136.71 & 136.79 & 136.56 & 135.17 & 135.07 & - \\
\hline $\begin{array}{l}\text { Ties (7" thick x 9" } \\
\text { wide) }\end{array}$ & 4,440 & - & - & - & - & - & 67.73 \\
\hline
\end{tabular}

Table 4.3.35: Specific Energy Consumption of Different Sizes in Sawmill 2-Cherry

\begin{tabular}{|l|c|c|c|c|c|c|}
\hline \multirow{2}{*}{ Size } & \multicolumn{6}{|c|}{ Specific Energy Consumption (kWh/MBF) } \\
\cline { 2 - 7 } & $\begin{array}{c}\text { 4 inch } \\
\text { Width }\end{array}$ & $\begin{array}{c}\text { 6 inch } \\
\text { Width }\end{array}$ & $\begin{array}{c}\text { 8 inch } \\
\text { Width }\end{array}$ & $\begin{array}{c}\text { 10 inch } \\
\text { Width }\end{array}$ & $\begin{array}{c}\text { 12 inch } \\
\text { Width }\end{array}$ & $\begin{array}{c}\text { 9 inch } \\
\text { Width }\end{array}$ \\
\hline 4/4 Size & 125.19 & 119.80 & 116.62 & 114.38 & 113.86 & - \\
\hline Cants (3" thick) & 34.95 & 34.97 & 34.91 & 34.55 & 34.53 & - \\
\hline $\begin{array}{l}\text { Ties (7" thick x 9" } \\
\text { wide) }\end{array}$ & - & - & - & - & - & 15.25 \\
\hline
\end{tabular}




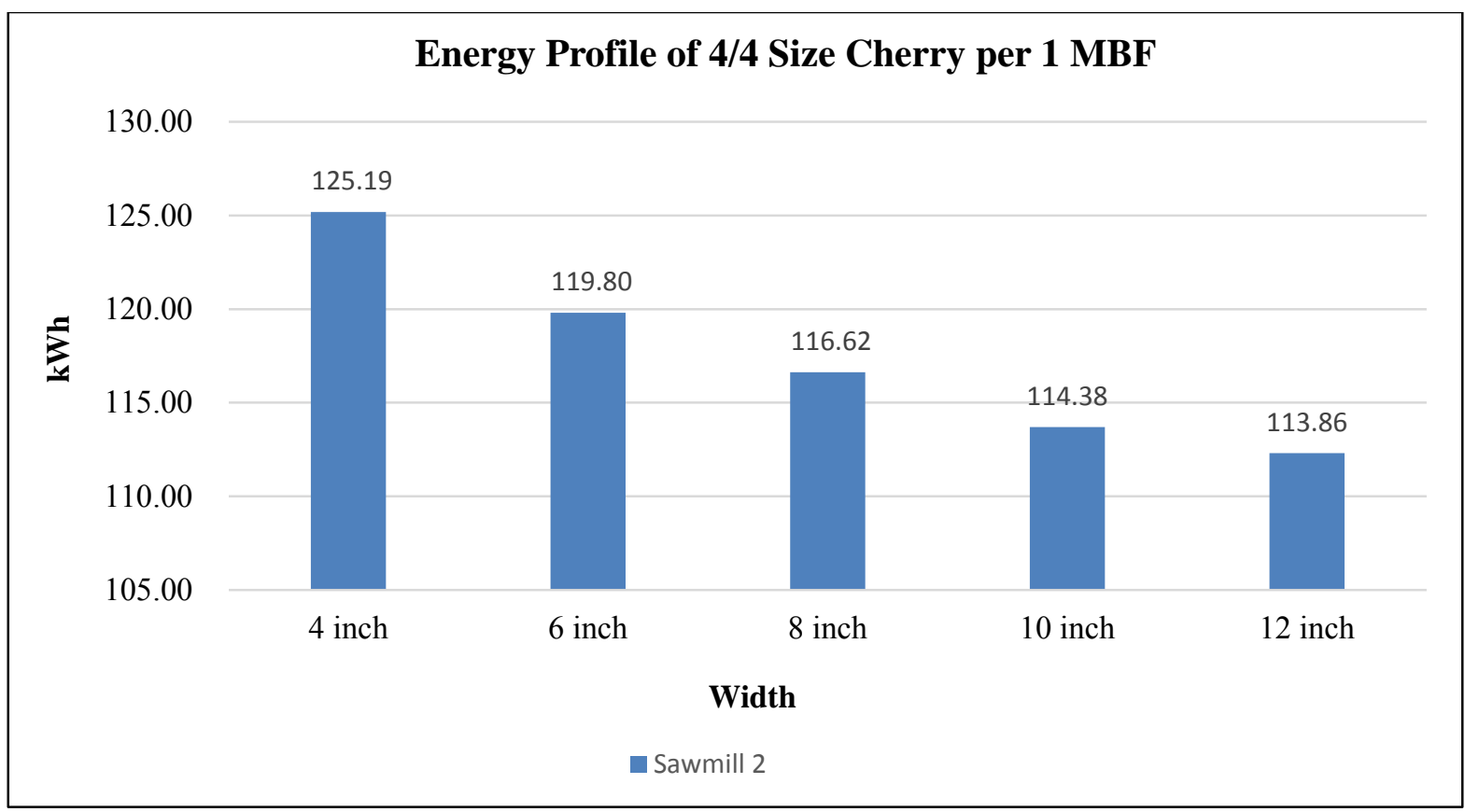

Figure 4.3.12: Energy Profile of 4/4 Size Lumber with Different Widths - Cherry

Overall, hickory and cherry were the major energy consumers followed by white oak and red oak. Specific energy consumption of all the species in Sawmill 2 was less than the other two sawmills. Sawmill 1 was found to be least efficient than other two sawmills. The Specific energy consumption of Sawmill 1 can be improved by changing the motor capacities and the details are discussed later in this section.

\subsection{Energy Consumption of Different Species Lumber of Same Size}

Specific energy consumption for varying lumber thicknesses were assessed. To help explain results, the specific energy consumption of 6 inch widths were considered for comparison. Because we do not have exact width data, results are based on simulated energy consumption for common width boards.

4/4 Size:

A total of 1,093,404 board feet of 4/4 size lumber was produced from different species and 125,920 $\mathrm{kWh}$ of electrical energy was consumed for its production from all the three sawmills. Cherry and hickory were the highest electricity consumers followed by white oak. Poplar was found to be the least energy consumer. In both Sawmill 1 and Sawmill 2, all the species followed the same pattern 
with respect to specific energy consumption. But in Sawmill 3, specific energy consumption of red oak was less than maple.

Table 4.4.1: Specific Energy Consumption of 4/4 Size Lumber of Different Species

\begin{tabular}{|l|c|c|c|}
\hline \multicolumn{1}{|c|}{ Species } & $\begin{array}{c}\text { Sawmill 1 } \\
(\mathbf{k W h / M B F})\end{array}$ & $\begin{array}{c}\text { Sawmill 2 } \\
\mathbf{( k W h / M B F})\end{array}$ & $\begin{array}{c}\text { Sawmill 3 } \\
\mathbf{( k W h / M B F})\end{array}$ \\
\hline Hickory & $146.80 \sim 185.86$ & $113.35 \sim 121.76$ & - \\
\hline White Oak & $137.97 \sim 175.17$ & $88.56 \sim 98.09$ & - \\
\hline Red Oak & $122.68 \sim 156.24$ & $86.08 \sim 94.93$ & $102.95 \sim 137.64$ \\
\hline Hard Maple & $112.05 \sim 142.70$ & $86.14 \sim 94.46$ & $121.84 \sim 160.93$ \\
\hline Poplar & $107.30 \sim 136.71$ & - & $75.00 \sim 100.64$ \\
\hline Soft Maple & - & $74.21 \sim 82.27$ & $111.50 \sim 148.30$ \\
\hline Ash & - & $78.14 \sim 86.91$ & $89.10 \sim 120.25$ \\
\hline Cherry & - & $113.86 \sim 125.19$ & - \\
\hline
\end{tabular}

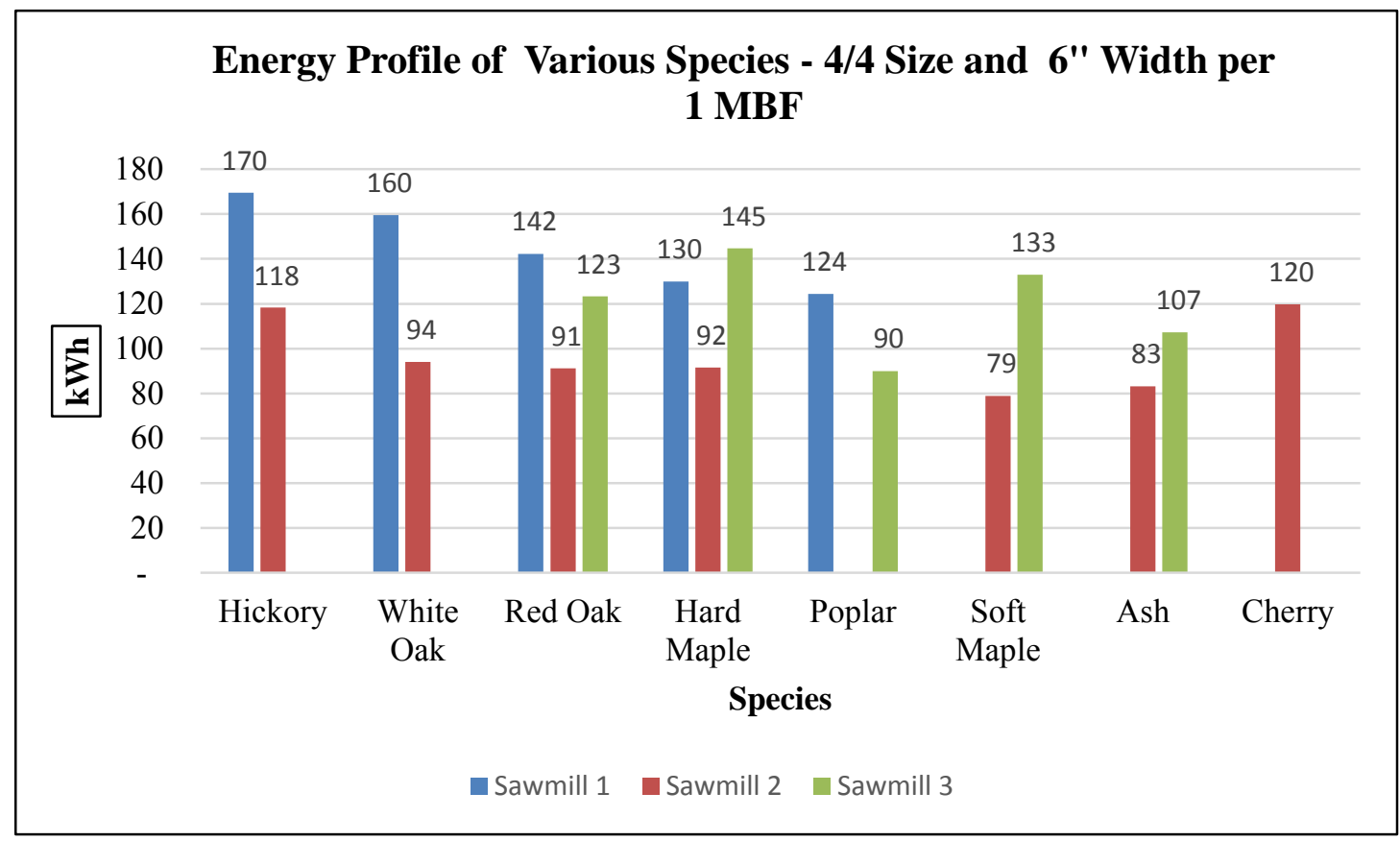

Figure 4.4.1: Energy Profile of Various Species - 4/4 Size and 6" Width

5/4 Size:

A total of 247,588 board feet of 5/4 size lumber was produced from 3 different species and 32,408 $\mathrm{kWh}$ of electrical energy was consumed for its production. Only white oak, red oak, and hard maple were sawn in 5/4 size lumber. 
Table 4.4.2: Specific Energy Consumption of 5/4 size lumber of Different Species

\begin{tabular}{|l|c|c|c|}
\hline \multicolumn{1}{|c|}{ Species } & $\begin{array}{c}\text { Sawmill 1 } \\
(\mathbf{k W h} / \text { MBF })\end{array}$ & $\begin{array}{c}\text { Sawmill 2 } \\
(\mathbf{k W h} / \mathbf{M B F})\end{array}$ & $\begin{array}{c}\text { Sawmill 3 } \\
(\mathbf{k W h} / \mathbf{M B F})\end{array}$ \\
\hline White Oak & $117.40 \sim 149.13$ & $71.60 \sim 80.28$ & $121.21 \sim 160.74$ \\
\hline Red Oak & - & $71.63 \sim 80.59$ & $82.70 \sim 110.38$ \\
\hline Hard Maple & - & $70.49 \sim 79.76$ & - \\
\hline
\end{tabular}

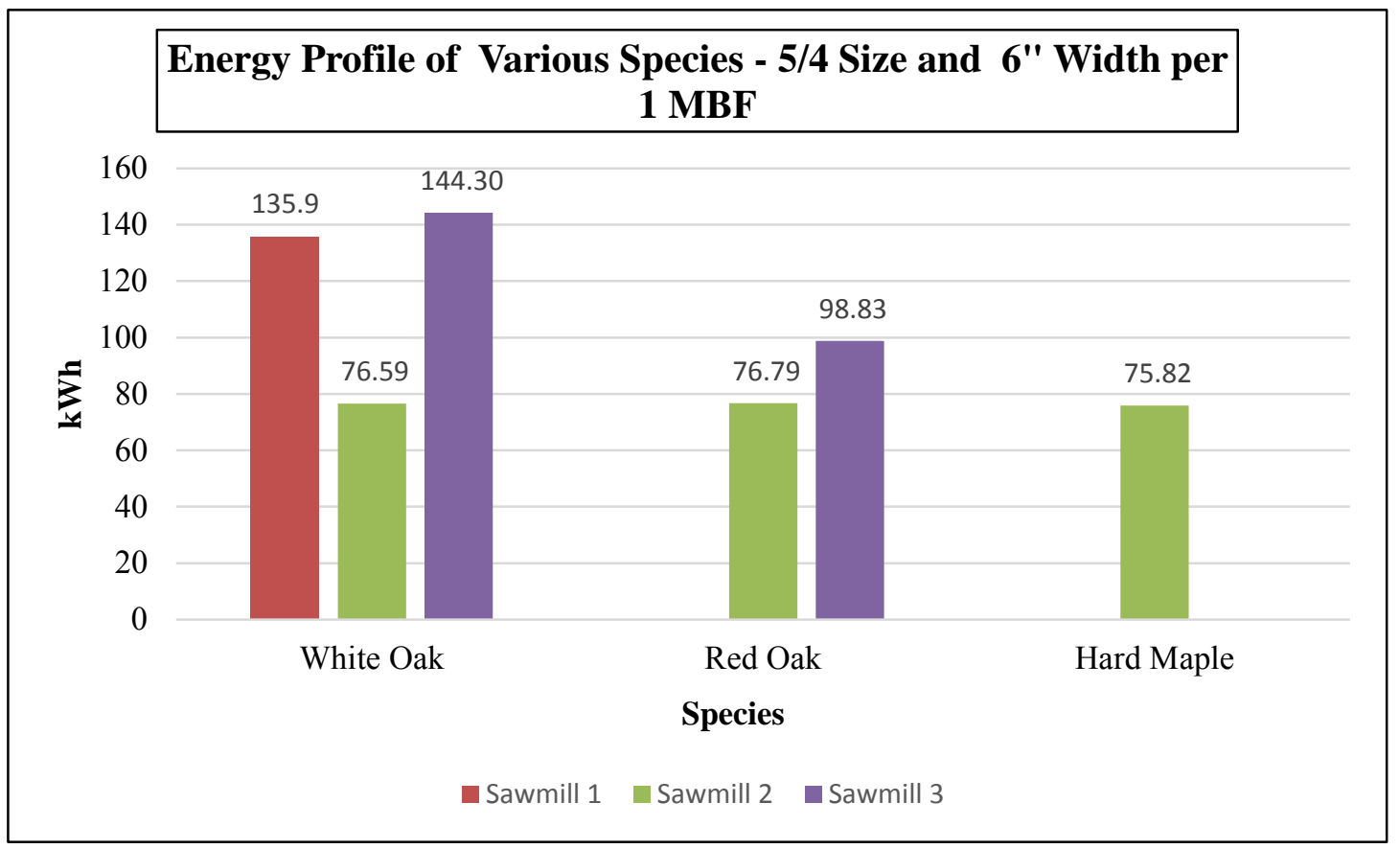

Figure 4.4.2: Energy Profile of Various Species - 5/4 Size and 6" Width

6/4 Size:

Only Sawmill 1 and Sawmill 2 produced 6/4 size lumber. A total of 19,902 board feet was produced from different species and $1,701 \mathrm{kWh}$ of electrical energy was consumed for its production.

Table 4.4.3: Specific Energy Consumption of 6/4 size lumber of Different Species

\begin{tabular}{|l|c|c|}
\hline \multicolumn{1}{|c|}{ Species } & $\begin{array}{c}\text { Sawmill 1 } \\
(\mathbf{k W h} / \text { MBF })\end{array}$ & $\begin{array}{c}\text { Sawmill 2 } \\
(\mathbf{k W h} / \mathbf{M B F})\end{array}$ \\
\hline White Oak & $81.86 \sim 104.85$ & $66.44 \sim 76.25$ \\
\hline Poplar & $79.84 \sim 102.91$ & - \\
\hline
\end{tabular}




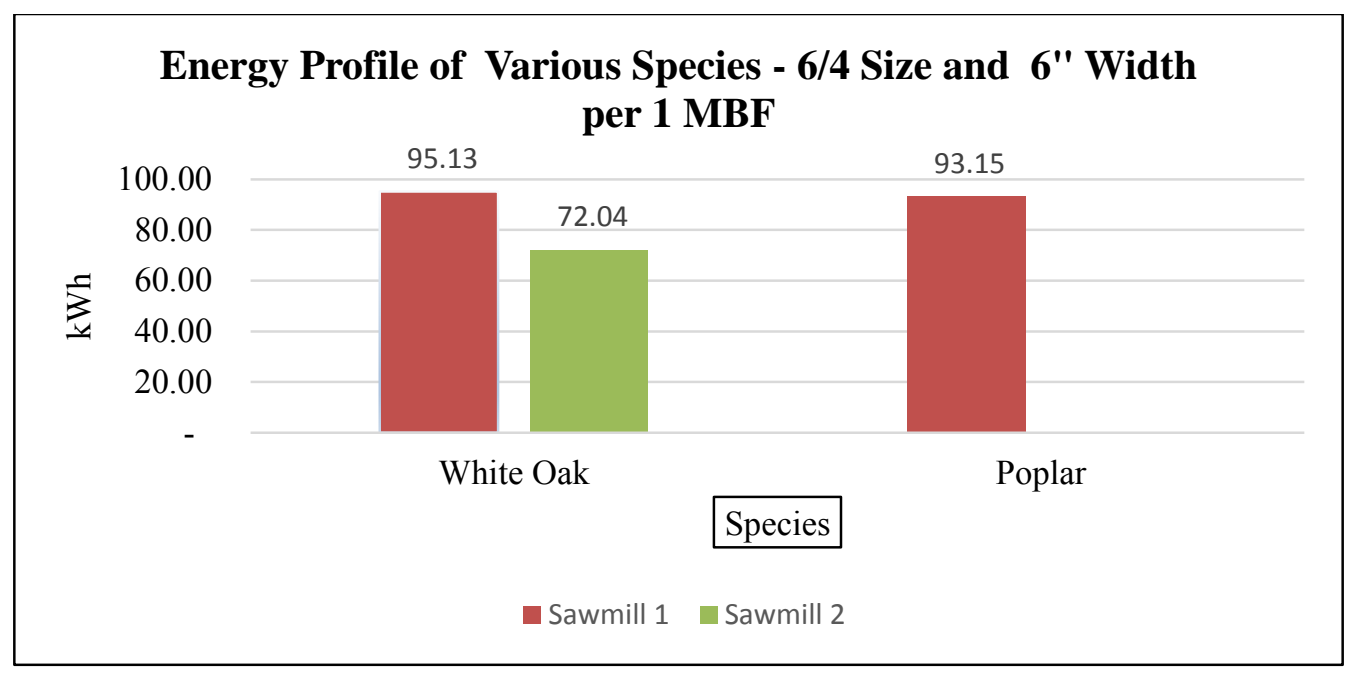

Figure 4.4.3: Energy Profile of Various Species - 6/4 Size and 6" Width

8/4 Size:

A total of 58,111 board feet of 8/4 size lumber was produced from different species and 3,587 kWh of electrical energy was consumed for its production in Sawmill 1 and Sawmill 2.

Table 4.4.4: Specific Energy Consumption of 8/4 size lumber of Different Species

\begin{tabular}{|l|c|c|c|}
\hline \multicolumn{1}{|c|}{ Species } & $\begin{array}{c}\text { Sawmill 1 } \\
(\mathbf{k W h} / \mathbf{M B F})\end{array}$ & $\begin{array}{c}\text { Sawmill 2 } \\
(\mathbf{k W h} / \mathbf{M B F})\end{array}$ & $\begin{array}{c}\text { Sawmill 3 } \\
(\mathbf{k W h} / \mathbf{M B F})\end{array}$ \\
\hline Red Oak & $70.47 \sim 92.09$ & $45.26 \sim 53.21$ & - \\
\hline Poplar & $62.08 \sim 81.13$ & - & $44.16 \sim 58.92$ \\
\hline Ash & - & - & $53.51 \sim 71.77$ \\
\hline
\end{tabular}

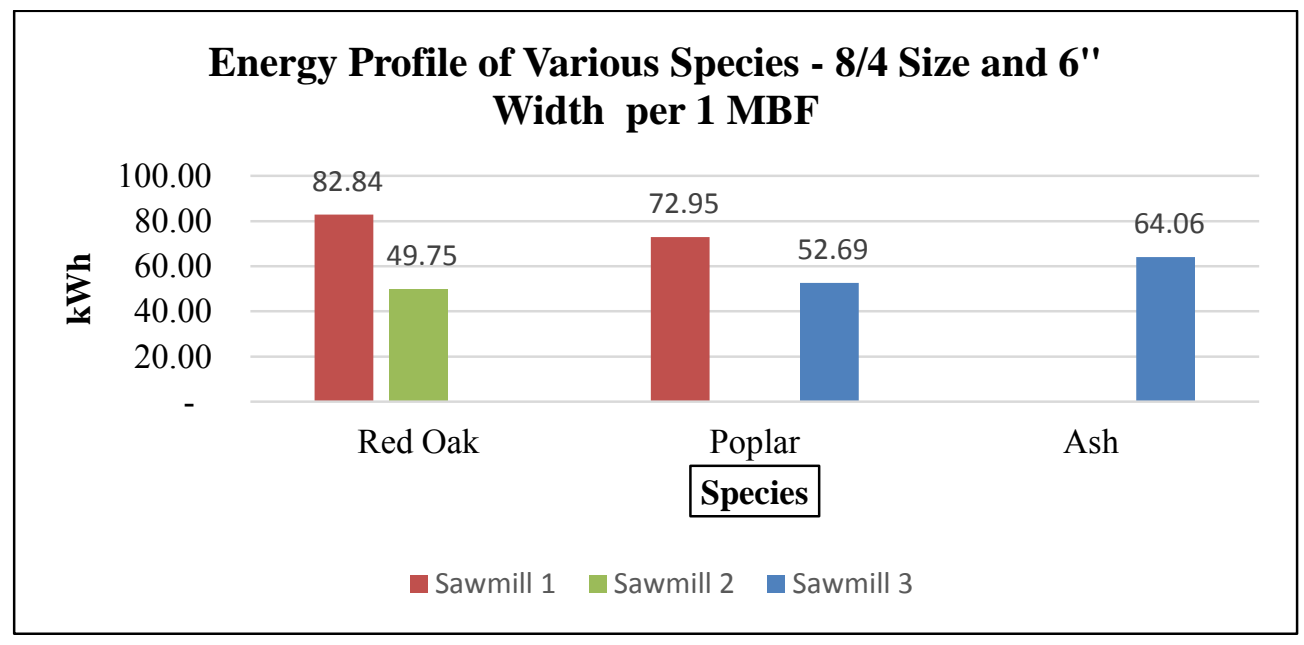

Figure 4.4.4: Energy Profile of Various Species - 8/4 Size and 6" Width 


\section{Cants (3 inch Thickness):}

A total of 26,729 board feet of cants with 3 inch thickness was produced from different species and $840 \mathrm{kWh}$ of electrical energy was consumed for its production in Sawmill 1 and Sawmill 2. It may be noted that the specific energy consumption of the cants was low compared to lumber consumption since this is the left over part of the log after lumber is sawn.

Table 4.4.5: Specific Energy Consumption of cants with 3" thickness of Different Species

\begin{tabular}{|c|c|c|}
\hline Species & $\begin{array}{c}\text { Sawmill 1 } \\
(\mathrm{kWh} / \mathrm{MBF})\end{array}$ & $\begin{array}{c}\text { Sawmill } 2 \\
(\mathrm{kWh} / \mathrm{MBF})\end{array}$ \\
\hline Hickory & - & $32.75 \sim 34.12$ \\
\hline White Oak & - & $25.49 \sim 25.76$ \\
\hline Red Oak & - & $25.96 \sim 26.21$ \\
\hline Hard Maple & - & $25.60 \sim 25.83$ \\
\hline Poplar & $31.86 \sim 39.12$ & - \\
\hline Soft Maple & - & $22.05 \sim 22.25$ \\
\hline Ash & - & $23.49 \sim 23.72$ \\
\hline Cherry & - & $34.53 \sim 34.97$ \\
\hline
\end{tabular}

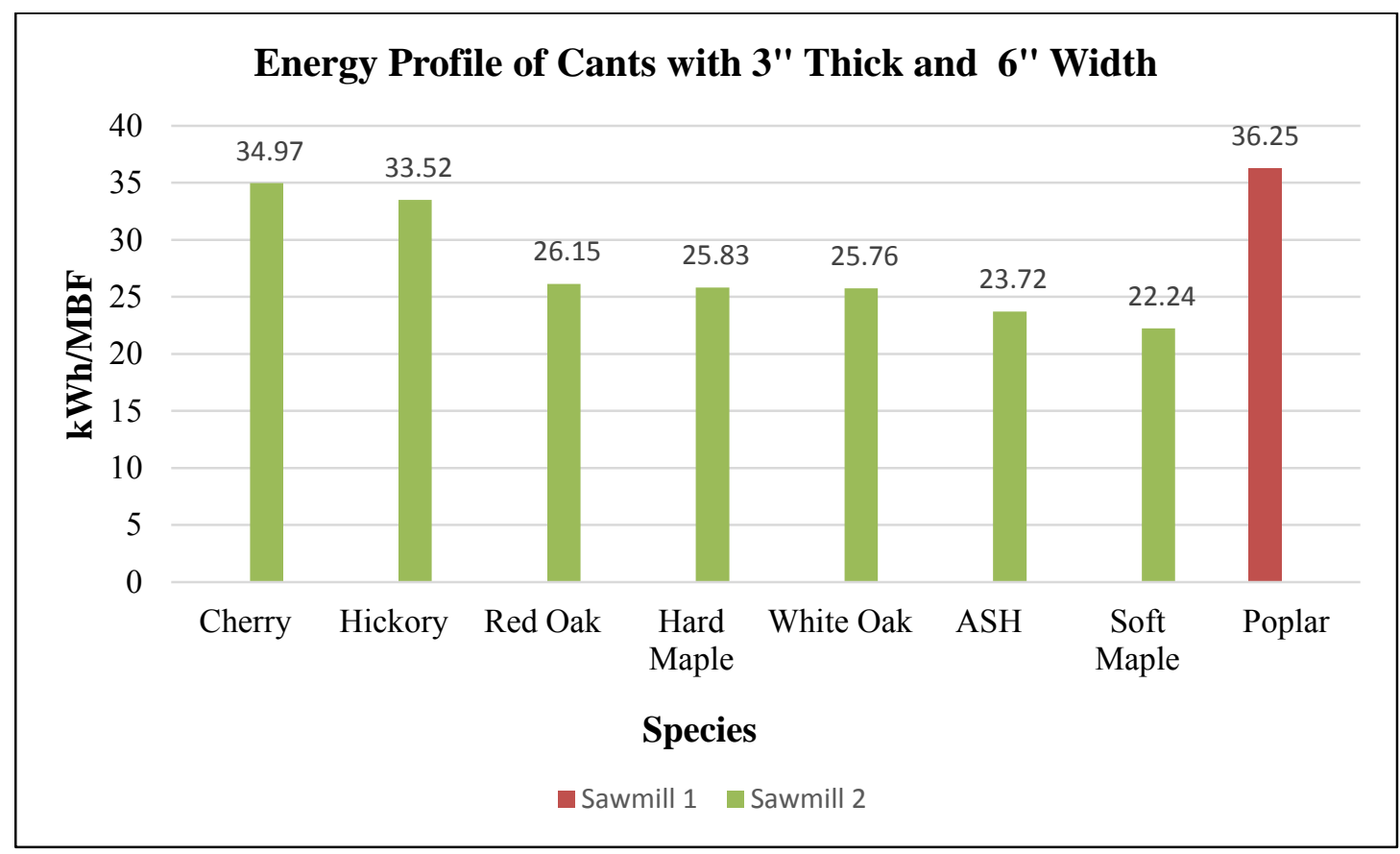

Figure 4.4.5: Energy Profile of Cants with 3" Thick and 6" Width 


\section{Cants (3.5inch Thickness):}

A total of 73,064 board feet of cants with 3.5 inch thickness was produced from different species and 2,837 kWh of electrical energy was consumed for its production in Sawmill 1 and Sawmill 3. Only two species were sawn in 3.5 inch thick cants in sawmill 1 whereas in Sawmill 3 four species were sawn. Red oak was the highest energy consumer in Sawmill 1 and white oak in Sawmill 3 for 3.5 inch cants.

Table 4.4.6: Specific Energy Consumption of cants with 3.5" thickness of Different Species

\begin{tabular}{|l|c|c|}
\hline \multicolumn{1}{|c|}{ Species } & $\begin{array}{c}\text { Sawmill 1 } \\
(\mathbf{k W h} / \text { MBF })\end{array}$ & $\begin{array}{c}\text { Sawmill 3 } \\
(\mathbf{k W h} / \mathbf{M B F})\end{array}$ \\
\hline Hard Maple & $27.06 \sim 33.20$ & $36.56 \sim 46.88$ \\
\hline Red Oak & $41.75 \sim 51.59$ & - \\
\hline Poplar & - & $16.96 \sim 23.00$ \\
\hline Sot Maple & - & $24.60 \sim 33.18$ \\
\hline White Oak & - & $36.57 \sim 47.68$ \\
\hline
\end{tabular}

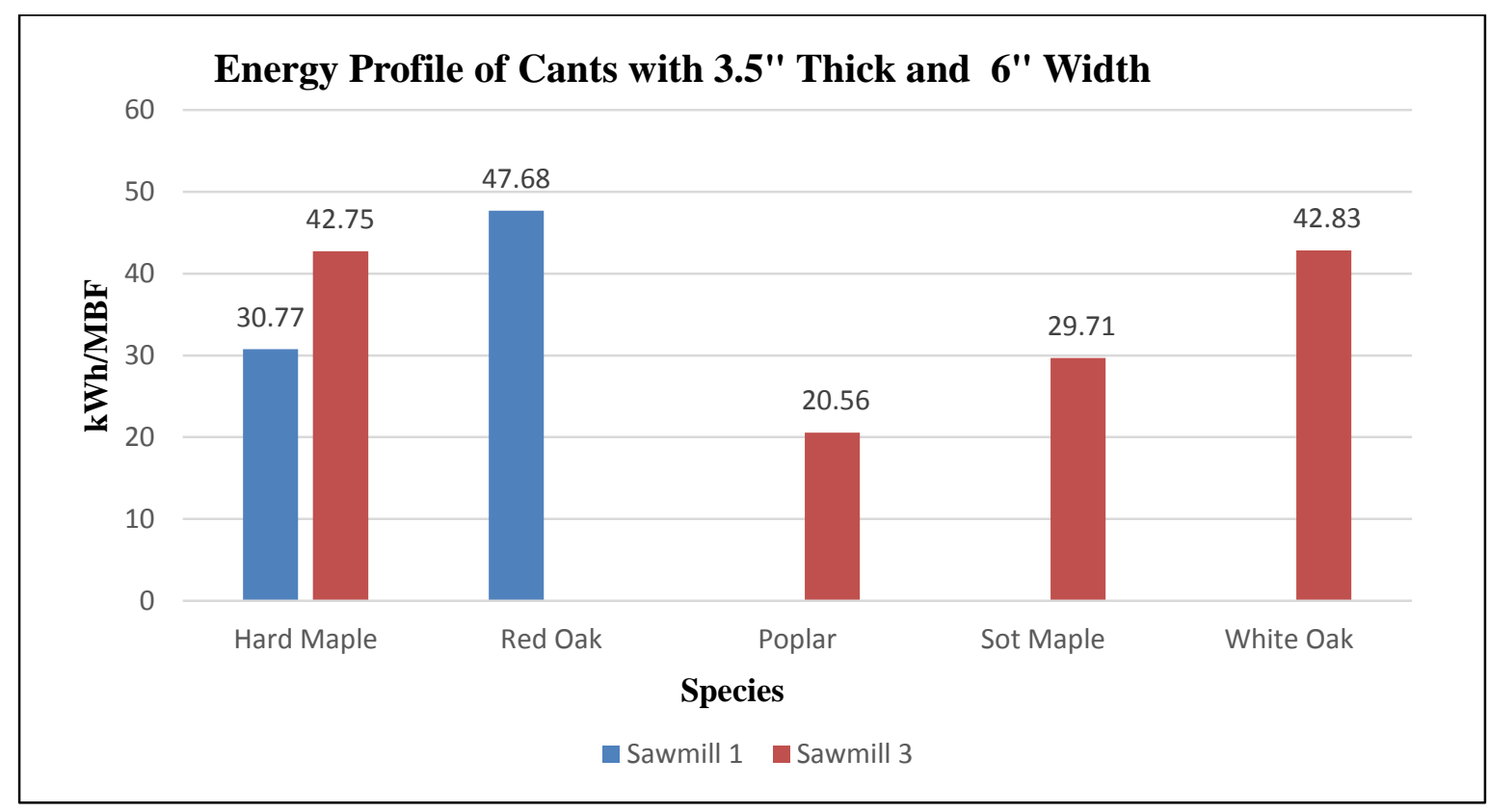

Figure 4.4.6: Energy Profile of Cants with 3.5" Thick and 6" Width 
Ties (7 inch thick and 9 inch width)

A total of 150,764 board feet of ties with 7 inch thickness and 9 inch width was produced from different species in all the 3 sawmills. During the production of ties $2,837 \mathrm{kWh}$ of electrical energy was consumed.

Table 4.4.7: Specific Energy Consumption of Ties of Different Species

\begin{tabular}{|l|c|c|c|}
\hline \multicolumn{1}{|c|}{ Species } & $\begin{array}{c}\text { Sawmill 1 } \\
(\mathbf{k W h} / \mathbf{M B F})\end{array}$ & $\begin{array}{c}\text { Sawmill 2 } \\
(\mathbf{k W h} / \mathbf{M B F})\end{array}$ & $\begin{array}{c}\text { Sawmill 3 } \\
(\mathbf{k W h} / \mathbf{M B F})\end{array}$ \\
\hline Hickory & 20.35 & - & - \\
\hline Hard Maple & 16.87 & 11.58 & - \\
\hline Poplar & 14.80 & - & - \\
\hline Red Oak & 19.99 & 10.66 & 13.78 \\
\hline Soft Maple & 20.54 & 9.13 & - \\
\hline White Oak & 18.59 & 10.90 & 20.41 \\
\hline Ash & - & 10.17 & - \\
\hline Cherry & - & 15.25 & - \\
\hline
\end{tabular}

As seen from the Figure 4.4.7, hickory can be considered as the species with the highest energy consumption followed by white oak.

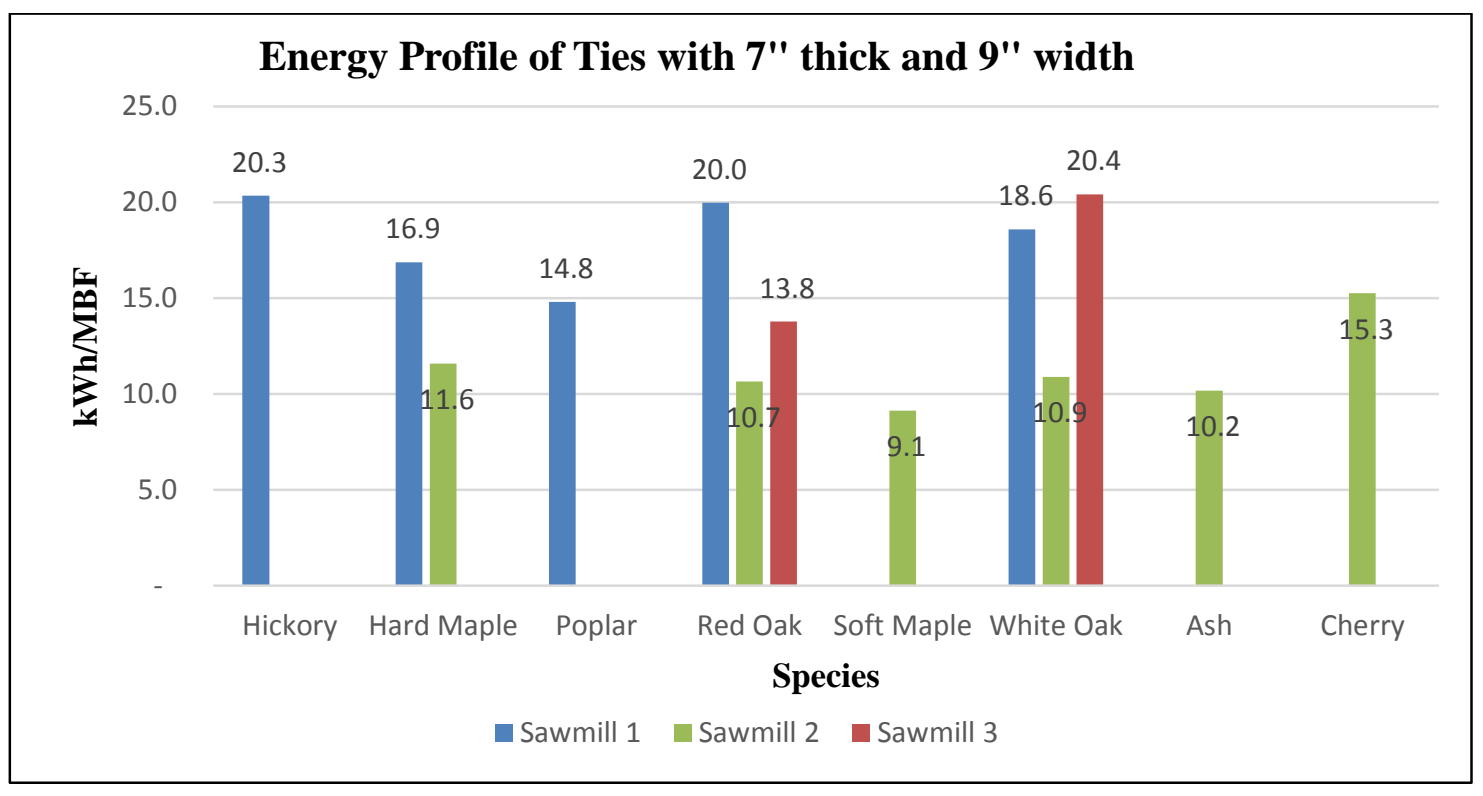

Figure 4.4.7: Energy Profile of Ties for Different Species 


\subsection{Energy consumption of different Motors}

As mentioned earlier, only some motors were directly involved in sawing operation during production of lumber. All motors in the study sawmills were classified as either sawing motors or process support motors. Sawing motors included main saw, re-saw, gang saw, edger, and trimmer. Since the carriage motor is attached to the main saw, it was also included in sawing motors. Energy consumption of sawing motors for the production of different sizes of lumber in all the 3 sawmills was compared in Table 4.5.1. The total lumber produced includes only thicknesses of 4/4, 5/4, 6/4, and 8/4 lumber. Sawmill 1 and Sawmill 3 consumed almost 4 times the energy as Sawmill 2. Since the major portion of the lumber was cut by re-saw (60 hp) in Sawmill 2, it consumed less energy compared to Sawmill 1 where all the logs were cut by main saw (200 hp). Sawmill 3 had larger sized motors with higher production rates compared to Sawmill 2. However, the energy consumption ratio of the sawing motors was much higher when compared to the production ratio, mainly due to the larger motors in Sawmill 3.

Table 4.5.1: Energy Consumption of Sawing Motors for the Production of Lumber

\begin{tabular}{|l|c|c|c|c|}
\hline Sawmill & $\begin{array}{c}\text { Total Lumber } \\
\text { Produced } \\
\text { (BF) }\end{array}$ & $\begin{array}{c}\text { Sawing Motors } \\
\text { Capacity } \\
\text { (HP) }\end{array}$ & $\begin{array}{c}\text { Total Energy } \\
\text { Consumed by } \\
\text { Sawing Motors } \\
\text { (kWh) }\end{array}$ & kWh/MBF \\
\hline Sawmill 1 & 210,512 & 425 & $12,405.10$ & 58.93 \\
\hline Sawmill 2 & 368,706 & 460 & $6,175.10$ & 16.75 \\
\hline Sawmill 3 & 839,787 & 650 & $58,478.78$ & 69.64 \\
\hline
\end{tabular}

One of the major motors in the process support equipment were the chippers. An analyses similar to the sawing motors was conducted for chippers and the results are shown below.

Table 4.5.2: Energy Consumption of Chipper for the Production of Lumber

\begin{tabular}{|l|c|c|c|c|}
\hline Sawmill & $\begin{array}{c}\text { Total Lumber } \\
\text { Produced } \\
\text { (BF) }\end{array}$ & $\begin{array}{c}\text { Chipper } \\
\text { Capacity } \\
\text { (HP) }\end{array}$ & $\begin{array}{c}\text { Chipper } \\
\text { Energy } \\
\text { Consumption } \\
\mathbf{( k W h )}\end{array}$ & $\mathbf{k W h / M B F}$ \\
\hline Sawmill 1 & 210,512 & 185 & $4,747.38$ & 22.55 \\
\hline Sawmill 2 & 368,706 & 150 & $2,446.34$ & 6.63 \\
\hline Sawmill 3 & 839,787 & 300 & $11,636.57$ & 13.86 \\
\hline
\end{tabular}


The chipper motor in Sawmill 1 and Sawmill 3 used significantly more energy than Sawmill 2. In Sawmill 1, the chipper was operating at idling condition for longer time periods due to slower production rate. The size of the motor in Sawmill 3 is likely the reason for more energy consumption.

Specific energy consumption mainly depends on load factors and size of the motors. Most of the motors in all 3 sawmills were found to be operating at lower load factors. As per industrial standards, a typical load factor of $70 \%$ or more is required to attain maximum motor efficiency [47]. Hence, motors with low load factor can result in higher energy consumption. All 3 sawmills could benefit from improving their load factors by using properly sized motors.

\subsection{Comparison of Re-sawing Motors in Sawmills}

As discussed in Chapter 1, some studies are available to calculate theoretical power required by sawing motors for cutting logs. Based on the study conducted by Mardikar [5], the theoretical power consumption required by the band saw for re-sawing operation is $20.8 \mathrm{~kW}$. Hence, horsepower (hp) required by the band saw can be calculated as,

$$
\begin{aligned}
\text { Horsepower required for re-sawing operation } \quad & =20.8 \mathrm{~kW} /(0.746 \mathrm{~kW} / \mathrm{Hp}) \\
& =27.9 \mathrm{hp}
\end{aligned}
$$

The motor capacity used for re-sawing operation in Sawmill 1, Sawmill 2 and Sawmill 3 are 200 $\mathrm{hp}, 60 \mathrm{hp}, 250 \mathrm{hp}$ respectively. Oversized motors in Sawmill 1 and Sawmill 3 have resulted in more energy consumption compared to Sawmill 2. Sawmill 1 and Sawmill 3 can benefit by resizing their motor capacities. Oversized motors also results in low power factor which is likely to be a factor in the increased power consumption that is evident in all sawmills.

\subsection{Energy consumption and Profit Analysis of the Logs}

As mentioned in chapter 3, high grade logs yield maximum proportions of high quality lumber. Calculated percentages of quality lumber obtained from the different grade logs were used for estimating profits in Table 4.7.3. The prices of different grade logs and different grade lumbers were collected from the Sawmill 3 and hardwood market annual lumber report [48]. The average price for different grade logs and lumber is shown in Table 4.7.1 and Table 4.7.2. 
Table 4.7.1: Prices of Different Grade Logs Obtained from Sawmill 3

\begin{tabular}{|l|c|c|c|}
\hline \multicolumn{1}{|c|}{ Species } & $\begin{array}{c}\text { High Grade } \\
\mathbf{L o g} \\
(\$ \mathbf{M B F})\end{array}$ & $\begin{array}{c}\text { Medium Grade Log } \\
(\$ / \mathbf{M B F})^{*}\end{array}$ & $\begin{array}{c}\text { Low Grade } \\
\text { Log } \\
(\$ / \mathbf{M B F})^{*}\end{array}$ \\
\hline Hickory & 500 & 350 & 200 \\
\hline White Oak & 700 & 525 & 400 \\
\hline Red Oak & 900 & 700 & 525 \\
\hline Hard Maple & 800 & 675 & 450 \\
\hline Ash & 450 & 300 & 200 \\
\hline Poplar & 500 & 300 & 150 \\
\hline Soft Maple & 500 & 400 & 250 \\
\hline Cherry & 1,100 & 900 & 650 \\
\hline
\end{tabular}

As mentioned earlier, high grade logs includes 4 clear face logs, medium grade logs includes 3 and 2 clear face logs, and low grade logs includes one clear face logs. 
Table 4.7.2: Prices of Different Grade Lumbers

\begin{tabular}{|c|c|c|c|c|c|c|c|c|c|}
\hline \multirow[b]{2}{*}{ Species } & \multicolumn{2}{|c|}{ 4/4 Size } & \multicolumn{2}{|c|}{ 5/4 Size } & \multicolumn{2}{|c|}{ 6/4 Size } & \multicolumn{2}{|c|}{ 8/4 Size } & \multirow[b]{2}{*}{$\begin{array}{c}\text { Cants } \\
(\$ / \mathrm{MBF})\end{array}$} \\
\hline & $\begin{array}{c}\text { High Grade } \\
\text { Lumber } \\
(\$ / \mathrm{MBF})\end{array}$ & $\begin{array}{c}\text { Low } \\
\text { Grade } \\
\text { Lumber } \\
(\$ / \mathrm{MBF})\end{array}$ & $\begin{array}{l}\text { High Grade } \\
\text { Lumber } \\
(\$ / \mathrm{MBF})\end{array}$ & $\begin{array}{l}\text { Low } \\
\text { Grade } \\
\text { Lumber } \\
(\$ / \mathrm{MBF})\end{array}$ & $\begin{array}{l}\text { High Grade } \\
\text { Lumber } \\
(\$ / \mathrm{MBF})\end{array}$ & $\begin{array}{c}\text { Low } \\
\text { Grade } \\
\text { Lumber } \\
\text { (\$/MBF) }\end{array}$ & $\begin{array}{l}\text { High } \\
\text { Grade } \\
\text { Lumber } \\
(\$ / \mathrm{MBF})\end{array}$ & $\begin{array}{c}\text { Low } \\
\text { Grade } \\
\text { Lumber } \\
(\$ / \mathrm{MBF})\end{array}$ & \\
\hline Hickory & 995 & 725 & 1,010 & 730 & 1,025 & 730 & 1,065 & 730 & 430 \\
\hline $\begin{array}{l}\text { White } \\
\text { Oak }\end{array}$ & 1,405 & 810 & 1,545 & 845 & 1,600 & 850 & 1,775 & 860 & 430 \\
\hline Red Oak & 1,395 & 815 & 1,425 & 845 & 1,440 & 850 & 1,505 & 860 & 430 \\
\hline $\begin{array}{l}\text { Hard } \\
\text { Maple }\end{array}$ & 1,445 & 1,050 & 1,480 & 1,050 & 1,495 & 1,065 & 1,550 & 1,085 & 430 \\
\hline Ash & 1,080 & 615 & 1,105 & 635 & 1,160 & 685 & 1,235 & 715 & 430 \\
\hline Poplar & 825 & 465 & 830 & 470 & 835 & 480 & 840 & 490 & 430 \\
\hline $\begin{array}{l}\text { Soft } \\
\text { Maple }\end{array}$ & 1,110 & 675 & 1,140 & 690 & 1,230 & 728 & 1,280 & 878 & 430 \\
\hline Cherry & 1,535 & 865 & 1,610 & 878 & 1,955 & 935 & 2,145 & 1,005 & 430 \\
\hline
\end{tabular}

The specific energy consumption (SEC) of Sawmill 2 is used in cost and profit analysis. By using SEC of Sawmill 2 and prices of the logs and lumber, the cost and profit analysis of sawing logs was calculated and is shown in Table 4.6.3. Sawmill operators can calculate the profit by using SEC values before sawing the log. This can help to predict their profit or loss scenario before sawing the logs. Since, the red oak was the most commonly sawn species in all the 3 sawmills, it is used for this analysis. The cost and profit analysis is calculated for sawing 10 MBF of red oak log to produce cants and 4/4", 5/4", 8/4" size lumber with 6 inch width. The cost and profits were calculated for three different grade logs. The average energy price of $\$ 0.10 / \mathrm{kWh}$ was considered for this analysis. Labor and overhead costs was considered as $15 \%$ of log cost based on discussion with the Sawmill 3 personnel. As an example, the profit for sawing high grade log to produce $4 / 4$ size lumber is calculated below. 
$\underline{\text { Lumber and Log Prices }}$

Log price for $10 \mathrm{MBF}$ of red oak (B)

$$
\begin{aligned}
& =\$ 900 / \mathrm{MBF} \times 10 \mathrm{MBF}=\$ \mathbf{9 , 0 0 0} \\
& =10,000 \mathrm{BF} \times 0.65=6,500 \mathrm{BF} \\
& =10,000 \mathrm{BF} \times 0.30=3,000 \mathrm{BF} \\
& =10,000 \mathrm{BF} \times 0.04=400 \mathrm{BF} \\
& =6,500 \mathrm{BF} \times(\$ 1,395 / 1,000 \mathrm{BF})=\$ 9,068 \\
& =3,000 \mathrm{BF} \times(\$ 815 / 1,000 \mathrm{BF})=\$ 2,445 \\
& =400 \mathrm{BF} \times(\$ 430 / 1000 \mathrm{BF})=\$ 172 \\
& =\$ 11,685
\end{aligned}
$$

High grade lumber obtained

Low grade lumber obtained

Cants obtained

High grade lumber price

Low grade lumber price

Cant price

Total lumber price (C)

\section{Energy Cost}

The energy consumptions considered in this analysis were as follows:

\begin{tabular}{|c|c|c|c|c|}
\hline & $\begin{array}{c}4 / 4 \text { Size } \\
(\mathrm{kWh} / \mathrm{MBF})\end{array}$ & $\begin{array}{c}5 / 4 \text { Size } \\
(\mathrm{kWh} / \mathrm{MBF})\end{array}$ & $\begin{array}{c}8 / 4 \text { Size } \\
(\mathrm{kWh} / \mathrm{MBF})\end{array}$ & $\begin{array}{c}\text { Cants } \\
(\mathrm{kWh} / \mathrm{MBF})\end{array}$ \\
\hline Red Oak & 91.26 & 76.79 & 49.75 & 26.15 \\
\hline
\end{tabular}

The energy consumption to produce $4 / 4$ size lumber $=(9,500 \mathrm{BF}) \times(91.26 \mathrm{kWh} / 1000 \mathrm{BF})$

$$
\begin{aligned}
& =866.97 \mathrm{kWh} \\
& =400 \mathrm{BF} \times 26.15 \mathrm{kWh} / 1000 \mathrm{BF} \\
& =10.46 \mathrm{kWh} \\
& =877.43 \mathrm{kWh} \\
& =877.43 \mathrm{kWh} \times \$ 0.10 / \mathrm{kWh}=\mathbf{\$ 8 7 . 7 4} \\
& =0.15 \times \$ 9,000=\mathbf{\$ 1 , 3 5 0} \\
& =\$ 1,247
\end{aligned}
$$

In a similar way, profits for the other grade logs and sizes were calculated and shown in Table 4.7.3. 
Table 4.7.3: Cost and Profit Analysis for Sawing 10 MBF of Red Oak Logs

\begin{tabular}{|c|c|c|c|c|c|c|c|c|}
\hline & \multicolumn{8}{|c|}{ High Grade Logs } \\
\hline $\begin{array}{l}\text { Size of } \\
\text { Lumber } \\
\text { Sawn } \\
\text { (Inches) }\end{array}$ & $\begin{array}{l}\text { Log Price } \\
\text { (\$) } \\
\text { (B) }\end{array}$ & $\begin{array}{l}\text { High Grade } \\
\text { Lumber } \\
\text { obtained in } \\
\text { BF }(65 \%)\end{array}$ & $\begin{array}{l}\text { Low Grade } \\
\text { Lumber } \\
\text { obtained in } \\
\text { BF }(30 \%)\end{array}$ & $\begin{array}{c}\text { Cants } \\
\text { obtained in } \\
\text { BF (4\%) }\end{array}$ & $\begin{array}{c}\text { Total } \\
\text { Lumber } \\
\text { Price } \\
\text { (\$) } \\
\text { (C) }\end{array}$ & $\begin{array}{c}\text { Energy } \\
\text { Cost } \\
\text { (\$) } \\
\text { (D) }\end{array}$ & $\begin{array}{c}\text { Labor }+ \\
\text { Overhead Cost } \\
(\$) \\
(\mathbf{E}=\mathbf{1 5 \%} \times \mathbf{B})\end{array}$ & $\begin{array}{l}\text { Profit } \\
\text { (\$) } \\
\text { (C-B- } \\
\text { D-E) }\end{array}$ \\
\hline $4 / 4 ”$ & 9,000 & 6,500 & 3,000 & 400 & 11,685 & 87.74 & 1,350 & 1,247 \\
\hline $5 / 4 "$ & 9,000 & 6,500 & 3,000 & 400 & 11,970 & 74.00 & 1,350 & 1,546 \\
\hline \multirow[t]{2}{*}{$8 / 4 "$} & 9,000 & 6,500 & 3,000 & 400 & 12,535 & 48.31 & 1,350 & 2,136 \\
\hline & \multicolumn{8}{|c|}{ Medium Grade Logs } \\
\hline $\begin{array}{l}\text { Size of } \\
\text { Lumber } \\
\text { Sawn } \\
\text { (Inches) }\end{array}$ & $\begin{array}{c}\text { Log Price } \\
(\$)\end{array}$ & $\begin{array}{l}\text { High Grade } \\
\text { Lumber } \\
\text { obtained in } \\
\text { BF }(30 \%)\end{array}$ & $\begin{array}{l}\text { Low Grade } \\
\text { Lumber } \\
\text { obtained in } \\
\text { BF }(60 \%)\end{array}$ & $\begin{array}{c}\text { Cants } \\
\text { obtained in } \\
\text { BF }(10 \%)\end{array}$ & $\begin{array}{l}\text { Total } \\
\text { Lumber } \\
\text { Price } \\
(\$)\end{array}$ & $\begin{array}{c}\text { Energy } \\
\text { Cost } \\
(\$)\end{array}$ & $\begin{array}{c}\text { Labor }+ \\
\text { Overhead Cost } \\
\qquad \$(\$)\end{array}$ & $\begin{array}{l}\text { Profit } \\
(\$)\end{array}$ \\
\hline $4 / 4 "$ & 7,000 & 3,000 & 6,000 & 500 & 9,290 & 83.44 & 1,050 & 1,157 \\
\hline $5 / 4 "$ & 7,000 & 3,000 & 6,000 & 500 & 9,560 & 70.42 & 1,050 & 1,440 \\
\hline \multirow[t]{2}{*}{$8 / 4^{\prime \prime}$} & 7,000 & 3,000 & 6,000 & 500 & 9,890 & 46.08 & 1,050 & 1,794 \\
\hline & \multicolumn{8}{|c|}{ Low Grade Logs } \\
\hline $\begin{array}{l}\text { Size of } \\
\text { Lumber } \\
\text { Sawn } \\
\text { (Inches) }\end{array}$ & $\begin{array}{l}\text { Log Price } \\
(\$)\end{array}$ & $\begin{array}{l}\text { High Grade } \\
\text { Lumber } \\
\text { obtained in } \\
\text { BF }(5 \%)\end{array}$ & $\begin{array}{l}\text { Low Grade } \\
\text { Lumber } \\
\text { obtained in } \\
\text { BF }(70 \%)\end{array}$ & $\begin{array}{c}\text { Cants } \\
\text { obtained in } \\
\text { BF }(15 \%)\end{array}$ & $\begin{array}{l}\text { Total } \\
\text { Lumber } \\
\text { Price } \\
\text { (\$) }\end{array}$ & $\begin{array}{c}\text { Energy } \\
\text { Cost } \\
(\$)\end{array}$ & $\begin{array}{c}\text { Labor }+ \\
\text { Overhead Cost } \\
\qquad \$(\$)\end{array}$ & $\begin{array}{l}\text { Profit } \\
(\$)\end{array}$ \\
\hline $4 / 4 "$ & 5,250 & 500 & 7,000 & 1,500 & 7,048 & 72.37 & 788 & 938 \\
\hline $5 / 4 "$ & 5,250 & 500 & 7,000 & 1,500 & 7,273 & 58.90 & 788 & 1,176 \\
\hline $8 / 4 "$ & 5,250 & 500 & 7,000 & 1,500 & 7,418 & 38.62 & 788 & 1,341 \\
\hline
\end{tabular}

As shown in Figure 4.7.1, profit margins are more for sawing high grade logs compared to medium and low grade logs. 


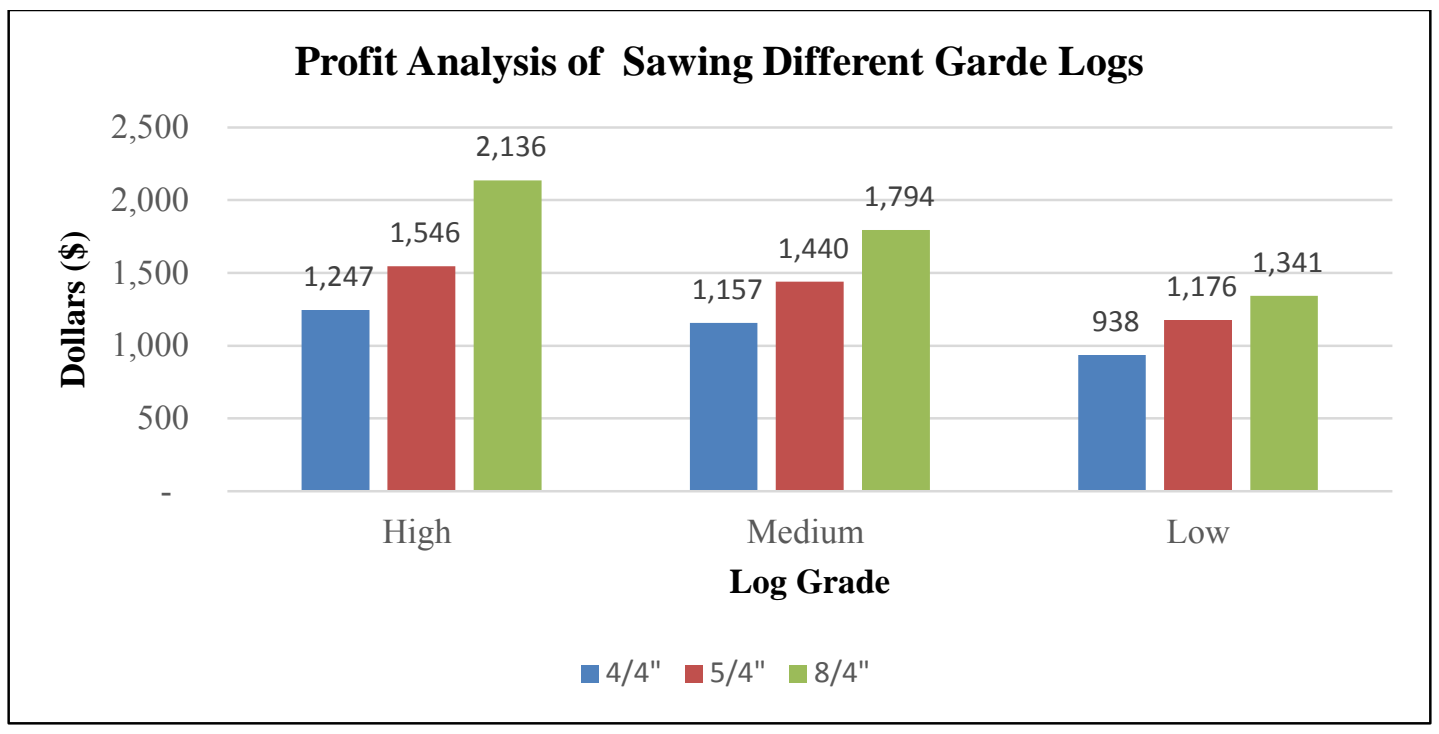

Figure 4.7.1: Profit Analysis of Red Oak Logs per $10 \mathrm{MBF}$

\subsection{Energy Assessments}

Energy assessments were conducted in all 3 sawmills to conserve energy at current operation. Energy conserving measures were developed for different energy systems. During the assessment, major energy systems that included compressed air, lighting, and motors were analyzed to save energy. Energy saving recommendations and dollar savings are presented in Table 4.8.1. Sawmill 1 can reduce its energy consumption by $12 \%$ after implementing the recommended energy conserving measures which can reduce the specific energy consumption of lumber. Similarly, Sawmill 2 and Sawmill 3 can also get benefited by implementing these recommendations. Sawmills can increase their profit margins by doing simple retrofits in their mills. 
Table 4.8.1: Energy Saving Recommendations Summary

\begin{tabular}{|c|c|c|c|c|c|c|}
\hline \multirow[b]{2}{*}{ Description } & \multicolumn{2}{|c|}{ Sawmill 1} & \multicolumn{2}{|c|}{ Sawmill 2} & \multicolumn{2}{|c|}{ Sawmill 3} \\
\hline & kWh & $\$$ & $\mathbf{k W h}$ & $\$$ & kWh & $\$$ \\
\hline Upgrade Lighting System & 3,382 & 338 & 10,183 & 1,018 & 44,847 & 4,485 \\
\hline Replace Drive belts with Cogged Belts & 15,046 & 1,505 & 22,595 & 2,260 & - & - \\
\hline $\begin{array}{l}\text { Perform Vibration Analysis on } \\
\text { Equipment }\end{array}$ & 10,591 & 1,059 & 28,244 & 2,824 & 109,621 & 10,962 \\
\hline Use Vortex Nozzles for Cleaning & 4,797 & 480 & 3,120 & 312 & - & - \\
\hline Reduce Air Pressure & 4,724 & 472 & 7,497 & 750 & 16,301 & 1,630 \\
\hline Repair Compressed Air Leaks & 4,270 & 427 & 5,570 & 557 & 18,524 & 1,852 \\
\hline Use Synthetic Lubricant in Compressors & 2,332 & 233 & - & - & - & - \\
\hline $\begin{array}{l}\text { Install Sequencer for the Compressed } \\
\text { Air System }\end{array}$ & - & - & - & - & 111,142 & 11,114 \\
\hline Total & 45,142 & 4,514 & 77,209 & 7,721 & 300,435 & 30,044 \\
\hline Annual Energy Consumption (kWh) & \multicolumn{2}{|c|}{381,525} & \multicolumn{2}{|c|}{422,538} & \multicolumn{2}{|c|}{$5,178,960$} \\
\hline$\%$ of Energy Savings & \multicolumn{2}{|c|}{$12 \%$} & \multicolumn{2}{|c|}{$18 \%$} & \multicolumn{2}{|c|}{$6 \%$} \\
\hline
\end{tabular}




\subsection{Productivity Improvement}

Saw blades used in the 3 sawmills were discussed in Chapter 3. As mentioned earlier, these sawmills were using conventional saw blades made out of hardened steel during the data logging period. There are modern blades available in the market with stellite tips which will increase the feed rate and yield and reduce the effort required by the motor. These modern saws offers longer run times and need very less maintenance [46]. Sawmill 2 is currently using stellite tipped blades for it's re-saw. As per the case studies [46] and discussions with Sawmill 2 maintenance people, these saws can easily increase the productivity by $10 \%$ or more. By changing the conventional blades with stellite tipped blades, sawmills can increase their productivity, reduce the labor time for maintenance, reduce the energy costs and increase the quality of the sawn lumber. As per the discussions with saw blade vendors, stellite tipped saws cost about 50\% more than regular conventional blades but last about 200\% longer. Thus, increased first cost is more than compensated for by the increased life time. The maintenance parameters of both conventional saws and stellite tipped saws are shown in Table 4.9.1

Table 4.9.1: Maintenance Parameters of Saws

\begin{tabular}{|l|c|c|c|c|c|c|}
\hline & \multicolumn{3}{|c|}{ Conventional Main Saw } & \multicolumn{3}{c|}{ Stellite Tipped Saw } \\
\hline & $\begin{array}{c}\text { Runtime } \\
\text { (Hours) }\end{array}$ & $\begin{array}{c}\text { Grinding Time } \\
\text { (Hours) }\end{array}$ & $\begin{array}{c}\text { Saw Changing Time } \\
\text { (Minutes) }\end{array}$ & $\begin{array}{c}\text { Runtime } \\
\text { (Hours) }\end{array}$ & $\begin{array}{c}\text { Grinding } \\
\text { Cost per one } \\
\text { time(\$) }\end{array}$ & $\begin{array}{c}\text { Saw Changing Time } \\
\text { (Minutes) }\end{array}$ \\
\hline Sawmill 1 & 4 & 2 & 10 & 16 & 94 & 10 \\
\hline Sawmill 2 & 3.5 & 1 & 10 & 8 & 47 & 10 \\
\hline Sawmill 3 & 5 & 3 & 5 & 16 & 94 & 5 \\
\hline & \multicolumn{7}{|c|}{ Conventional Re- Saw } & & - & Stellite Tipped Saw \\
\hline Sawmill 1 & - & - & - & 16 & 47 & - \\
\hline Sawmill 2 & 4 & 1 & 15 & 16 & 94 & 15 \\
\hline Sawmill 3 & 5 & 3 & 5 & & 5 \\
\hline
\end{tabular}


As shown in Table 4.9.3, using stellite tipped saws in place of conventional blades will help all the 3 sawmills to save in terms of labor, machine cost, productivity and energy. The increase in the productivity and energy savings are considered as $10 \%$. The estimated costs for this analysis were shown in Table 4.9.2. There will also be overhead savings which are not considered in this analysis. There will be more energy savings due to better cutting performance of stellite tipped saws compared to conventional saws.

Table 4.9.2: Estimated Costs

\begin{tabular}{|l|c|}
\hline \multicolumn{1}{|c|}{ Species } & $\begin{array}{c}\text { Cost } \\
\text { (\$/hour) }\end{array}$ \\
\hline $\begin{array}{l}\text { Grinding Cost of } \\
\text { Conventional Blades }\end{array}$ & 20 \\
\hline Labor Cost & 10 \\
\hline Machine Cost & 50 \\
\hline
\end{tabular}

As an example, the cost savings by using stellite tipped saw and energy cost savings due to productivity improvement for Sawmill 1 are calculated as follows:

Cost Savings by Using Stellite Tipped Saw per Month

Total operating hours in a month $\quad=179$ hours

Total grinding time for conventional main saw $\quad=(179$ hours/run time $) \times$ Grinding time

$=(179 / 4) \times 2$ hours $=89.5$ hours

Total grinding cost for conventional main saw $(\mathrm{W})=89.5$ hours $\mathrm{x} \$ 20 /$ hour $=\mathbf{\$ 1 , 7 9 0}$

Total grinding cost for stellite tipped saw $(\mathrm{X}) \quad=(179$ hours $/ 16$ hours $)$ x $\$ 94=\mathbf{\$ 1 , 0 5 2}$

Reduced machine hours due to productivity increase $=179$ hours $x 0.10=17.9$ hours

Reduced labor hours due to productivity increase $\quad=179$ hours x $0.10=17.9$ hours

Total cost savings from machine hours $(\mathrm{Y}) \quad=17.9$ hours $\times \$ 50 /$ hour $=\$ \mathbf{8 9 5}$

Total cost savings from labor hours $(Z) \quad=17.9$ hours $x \$ 10 /$ hour $=\$ \mathbf{1 7 9}$

Monthly cost savings $(\mathrm{S}=\mathrm{W}+\mathrm{Y}+\mathrm{Z}) \quad=\mathbf{\$ 2 , 8 6 4}$

Net cost savings per month $(\mathrm{T}=\mathrm{S}-\mathrm{X}) \quad=\$ 1,812 /$ month

Annual cost savings per year $(\mathrm{U}=12 \times \mathrm{T}) \quad=\$ 1,812 /$ month $\times 12=\$ \mathbf{2 1 , 7 4 4}$ 


\section{Energy cost savings per month}

Energy savings due to increase in productivity

$=\quad 10 \%$ of monthly energy consumption

Energy cost savings per month

$=0.10 \times 35,154 \mathrm{kWh}=3,515 \mathrm{kWh}$

$=\quad 3,515 \mathrm{kWh} \times \$ 0.10 / \mathrm{kWh}=\$ 351.5$

Energy cost savings per year

$=\$ 351.5 \times 12=\$ 4,214 /$ year

In a similar way, savings for other sawmills were calculated and shown in Table 4.9.3 and Table 4.9.4.

Table 4.9.3: Cost Savings by Using Stellite Tipped Saws

\begin{tabular}{|l|c|c|c|c|c|c|c|}
\hline & $\begin{array}{c}\text { Total } \\
\text { Operating } \\
\text { Hours in a } \\
\text { Month }\end{array}$ & $\begin{array}{c}\text { Grinding } \\
\text { Time } \\
\text { Saved } \\
\text { (Hours) }\end{array}$ & $\begin{array}{c}\text { Reduced } \\
\text { Labor/Machine } \\
\text { Hours }\end{array}$ & $\begin{array}{c}\text { Monthly Cost } \\
\text { Savings (\$) } \\
(\mathrm{S})\end{array}$ & $\begin{array}{c}\text { Stellite Tipped } \\
\text { Saw Grinding } \\
\text { Cost }(\$) \\
(\mathrm{X})\end{array}$ & $\begin{array}{c}\text { Net Cost } \\
\text { Savings per } \\
\text { Month } \\
(\$) \\
\mathrm{T}=(\mathrm{S}-\mathrm{X})\end{array}$ & $\begin{array}{c}\text { Annual } \\
\text { Savings } \\
(\$) \\
(\mathrm{U}=12 \times \mathrm{T})\end{array}$ \\
\hline Sawmill 1 & 179 & 89.5 & 17.9 & 2,864 & 1,052 & 1,812 & 21,744 \\
\hline Sawmill 2 & 144 & 41 & 14.4 & 1,687 & 846 & 841 & 10,090 \\
\hline Sawmill 3 & 214 & 128 & 21.4 & 3,852 & 1,257 & 2,595 & 31,137 \\
\hline & \multicolumn{7}{|l|}{ Main Saw } \\
\hline Sawmill 1 & - & - & - & Re-saw & & \\
\hline Sawmill 2 & 144 & 36 & 14.4 & 1,584 & 423 & 1,161 & 13,932 \\
\hline Sawmill 3 & 214 & 128 & 21.4 & 3,852 & 1,257 & 2,595 & 31,137 \\
\hline
\end{tabular}


Table 4.9.4: Summary of the Savings

\begin{tabular}{|l|c|c|c|}
\hline \multicolumn{1}{|c|}{ Sawmill } & $\begin{array}{c}\text { Cost Savings } \\
\text { per year } \\
\text { (\$) }\end{array}$ & $\begin{array}{c}\text { Energy Cost } \\
\text { Savings Per } \\
\text { Year (\$)* }\end{array}$ & $\begin{array}{c}\text { Productivity } \\
\text { Improvement } \\
\text { (Board Feet) }\end{array}$ \\
\hline Sawmill 1 & 21,744 & 4,214 & 42,069 \\
\hline Sawmill 2 & 24,022 & 4,544 & 46,099 \\
\hline Sawmill 3 & 62,274 & 13,416 & 99,189 \\
\hline
\end{tabular}

*Energy cost was calculated based on the average $\mathrm{kWh}$ rate $\$ 0.10$.

\subsection{Conclusion}

Energy profiles and specific energy consumption were developed for multiple species and lumber sizes for three sawmills sampled in West Virginia. Specific energy consumption of thinner lumber sizes like $4 / 4$ and pallet is higher than the thicker lumber sizes like cants and timbers. The higher energy consumption recorded during the sawing of thinner lumber can be clearly explained by less volume of lumber present in their boards compared to thicker lumber boards of cants and timbers. From the analysis it was seen that harder species like Hickory and white Oak consumed more energy than softer species like Yellow-poplar and Ash. Energy consumption profiles help sawmill owners understand how much energy is required to produce unit quantity of lumber of a particular size and species. Since Sawmill 2 was more energy efficient than the other 2 sawmills, the specific energy consumption of Sawmill 2 can be considered as standard energy consumption for bench marking. The specific energy consumption of the three sawmills were calculated by simulating the collected data and hence, these results may not represent the actual standard specific energy consumptions. Based on energy profiles of Sawmill 2, the specific energy consumption of hardhardwoods for $4 / 4$ size lumber can be considered as $91 \mathrm{kWh} \sim 118 \mathrm{kWh}$ and for soft-hardwoods as $79 \mathrm{kWh} \sim 83 \mathrm{kWh}$. The specific energy consumptions of the other two sawmills were shown in Table 4.10.1.

Table 4.10.1: Summary of the Specific Energy Consumptions

\begin{tabular}{|l|c|c|c|}
\hline \multicolumn{1}{|c|}{ Hardwood } & $\begin{array}{c}\text { Sawmill 1 } \\
(\mathbf{k W h} / \mathbf{M B F})\end{array}$ & $\begin{array}{c}\text { Sawmill 2 } \\
\text { (kWh/MBF) }\end{array}$ & $\begin{array}{c}\text { Sawmill 3 } \\
(\mathbf{k W h} / \mathbf{M B F})\end{array}$ \\
\hline Hard Hardwood & $130 \sim 170$ & $91 \sim 118$ & $123 \sim 145$ \\
\hline Soft Hardwood & 124 & $79 \sim 83$ & $90 \sim 107$ \\
\hline
\end{tabular}


If Sawmill 1 can improve its energy efficiency to match Sawmill 2, considering the specific energy consumption of 4/4 size red-oak species the Sawmill 1 can save 55,558 kWh ((142 kWh/MBF $91 \mathrm{kWh} / \mathrm{MBF}) \times(90,781 \mathrm{BF} / 1000) \times 12$ months/year) or $\$ 5,558 / \mathrm{yr}$ for the average cost of $\$ 0.1 / \mathrm{kWh}$. In a similar way, Sawmill 3 can also benefit by improving its energy efficiency. Further, installing retrofits and using new saw blade technologies can help sawmills to reduce their energy consumption and improve productivity. 


\section{$5 \quad$ Future Work}

The energy profiles developed in this analysis used real time electrical data from the data loggers and production details provided by the sawmill personnel. These profiles provides a methodology to help sawmill personnel to benchmark their energy usage and improve their energy efficiency. However, the following work would lead to an improved and more useful energy profiles.

\subsection{Log Tracking by RFID}

The real time tracking of logs in a sawmill by using RFID technology would provide accurate production information from the different logs sawn. The energy profiles were developed based on production output during every shift provided by plant personnel. RFID technology would help in tracking of individual log and its productivity. Real time production data at each time interval along with real time electrical data would increase the transparency of the energy profiles. This technology helps in improving the yield and reducing the wastage within the facility. Combination of RFID and current data loggers would help in estimating carbon foot print of each board lumber sawn more accurately.

\subsection{Electrical Energy (kWh) Data Loggers}

The energy consumption of the motors in each sawmill was calculated based on the amperage data obtained from the data loggers and instant readings of voltage and power factor from the clamp on meter. Amperage data was monitored throughout the production period whereas voltage and power factor values were measured approximately for 30 minutes and the same values were considered for the entire production period. The electrical energy data loggers called as kWh loggers are the latest sensors that can monitor the $\mathrm{kWh}$ data of electrical equipment. The electrical energy consumption can be directly obtained by using these data loggers. These loggers eliminate the errors that might occur due to estimation of voltage and power factors. The accurate electrical energy obtained would improve the credibility of the energy profiles.

\subsection{Develop Advanced Monitoring System}

Sawmills would be benefited by using the advanced monitoring system which can communicate with the RFID tag and kWh sensors to generate energy profiles on a daily basis. This kind of 
system can bring immense help to the facility personnel to keep track of their productivity and waste. 


\section{References}

[1] Williston, E. M., 1988, "The Design and Operation of Sawmills and Planer Mills. Revised Edition," Miller Freeman Publications, pp. 5-8, Chap. 1.

[2] Appalachian Hard Wood Center, "2014 WV Forest Products Industry Directory," http://ahc.Caf.Wvu.edu/remository/Forest-Products/2014-WV-Forest-Products-IndustryDirectory/, 2014(Jul/25).

[3] Devaru, D. G., Maddula, R. B., and Grushecky, S. T; and Gopalakrishnan, B., 2014, "Motor Based Energy Consumption in West Virginia Sawmills," Forest Products Journal., 64(1/2). pp. 33 40 .

[4] Mardikar, Y., 2007, "Establishing Baseline Electrical Energy Consumption in Wood Processing Sawmills: A Model Based on Energy Analysis and Diagnostics," Ph.D Dissertation, West Virginia University, Morgantown, WV.

[5] Industrial Assessment Center Reports Database, 2014, IOF-WVDO, Morgantown, WV.

[6] Reduce Energy Use at Lumber \& Wood Processing Facilities, " Efficiency

Vermont,Opportunities for a Better Bottom Line," http:/www.Efficiencyvermont.com/stella/filelib/EVT_lumbertechFinal.Pdf, 2013(Nov/25).

[7] Denig, J., 1993, "Small Sawmill Handbook: Doing it Right and Making Money," Miller Freeman, San Francisco, pp. 39-72, Chap. 3.

[8] Williston, E. M., 1988, "Lumber Manufacturing: The Design and Operation of Sawmills and Planer Mills, Revised Edition," Miller Freeman Publications, pp. 45-57, Chap. 6.

[9] Sawmills Equipment and Operations of 20th Century Sawmills, http://www.Climaxlocomotives.com/sawmills/?pg=7, 2013(November/19).

[10] Williston, E. M., 1988, "The Design and Operation of Sawmills and Planer Mills, Revised Edition," Miller Freeman Publications, pp. 104-108, Chap. 10.

[11] Williston, E. M., 1988, "The Design and Operation of Sawmills and Planer Mills, Revised Edition." Miller Freeman Publications, pp. 109-121, Chap. 11. 
[12] Denig, J., 1993, "Small Sawmill Handbook: Doing it Right and Making Money." Miller Freeman, San Francisco, pp. 99-119, Chap. 5.

[13] Williston, E. M., 1988, "Lumber Manufacturing: The Design and Operation of Sawmills and Planer Mills, Revised Edition," Miller Freeman Publications, pp. 142-157, Chap. 14.

[14] Brown, T. D., "Wasting Dollars in the Sawmill”, Department of Forest Products, Oregon State University. http://ir.Library.Oregonstate.edu/xmlui/bitstream/handle/1957/5615/?sequence=1, 2013(Nov/19).

[15] Dubois, M. R., Watson, W. F., and Wagner, F. G., "Chip Quality Survey for Sawmills in the Southeastern United States," Department of Forestry, Mississippi State http://msucares.com/pubs/bulletins/b0983.Pdf, 2013(November/21).

[16] Williston, E. M., 1988, "Lumber Manufacturing: The Design and Operation of Sawmills and Planer Mills, Revised Edition," Miller Freeman Publications, pp. 216-224, Chap. 20.

[17] Milota, M. R., West, C. D., and Hartley, I. D., 2005, "Gate-to-Gate Life-Cycle Inventory of Softwood Lumber Production," Wood and Fiber Science., 37, pp. 47-57.

[18] Bergman, R. D., and Bowe, S. A., 2008, "Environmental Impact of Producing Hardwood Lumber using Life-Cycle Inventory," Wood and Fiber Science., 40(3), pp. 448-458.

[19] Poole, A., and Pinheiro, P., "Developing Energy Profiles for Sawmills in the Amazon Region First Field Visit to Rondolândia and Ji-Paraná, http://www.Inee.Org.br/down_loads/biomassa/AmazonSawmill.pdf\#search=\%22energy\%20prof iling\%20of\%20sawmill\%22, 2013(December/5).

[20] Li, J., McCurdy, M., and Pang, S., 2006, "Energy Demand in Wood Processing Plants," New Zealand Journal of Forestry., 51(2), pp. 13-18.

[21] Gopalakrishnan, B., Mardikar, Y., Gupta, D., 2012, "Establishing Baseline Electrical Energy Consumption in Wood Processing Sawmills for Lean Energy Initiatives: A Model Based on Energy Analysis and Diagnostics," Energy Engineering., 109(5), pp. 40-80. 
[22] Lin, W., Wang, J., Grushecky, S. T., 2012, "Energy Consumption and Efficiency of Appalachian Hardwood Sawmills," Forest Products Society Journal., 62(1), pp. 32-38.

[23] Espinoza, O., Buehlmann, U., and Bond, B. H., 2011, "Energy and the US Hardwood Industry - Part II: Responses to Increasing Prices," Bioresources., 6(4), pp. 3899-3914.

[24] Bond, B. H., 2008, "Sawmill \& Treating Insights: Rein in Escalating Energy Costs," http://www.Palletenterprise.com/articledatabase/view.Asp?articleID=2648, 2013(November/9).

[25] Anderson, J. O., 2012, "Improving Energy use in Sawmills: From Drying Kilns to National Impact," Licentiate Thesis, Sweden. Luleå University of Technology.

[26] Significant Reduction in Energy and Water Consumption, 2007, "Energy Efficiency and Cleaner Production Measures at Sawmill 25," Archangelsk Oblast Energy Efficiency Centre and Norsk Energi.

[27] Wengert, G., and Meyer, D., 1992, "Energy at the Sawmill: Conservation and Cost Reduction," Department of Forest Ecology and Management, University of Wisconsin.

[28] Anderson, J. O., and Toffolo, A., 2013, "Improving Energy Efficiency of Sawmill Industrial Sites by Integration with Pellet and CHP Plants," Applied Energy., 111, pp. 791-800.

[29] Spinelli, R., Cavallo, E., Eliasson, L., 2013, "Comparing the Efficiency of Drum and Disc Chippers," The Finnish Society of Forest Science., 47(2), pp. 11.

[30] U.S. Energy Information Administration, 2010, "Manufacturing Energy Consumption Survey," http://www.Eia.Gov, 2013(November/25).

[31] Lumber Production and Mills Stocks, https://www.Census.gov/manufacturing/cir/historical_data/ma321t/, 2013(October/31).

[32] Hodges, D. G., Hartsell, A. J., Brandeis, C., 2012, "Recession Effects on the Forests and Forest Products Industries of the South," Forest Product Journal., 61(8), pp. 614-624.

[33] Parhizkar,O., Smith, R. L., and Miller, C. R., 2009, "Comparison of Important Competitiveness Factors for Small- to Medium-Sized Forest Enterprises," Forest Products Journal., 59(5), pp. 81-86. 
[34] Wang, J., Wu, J., Aromstrong, J. P., 2010, "Appalachian Hardwood Product Exports: An Analysis of the Current Chinese Market." Forest Product Journal., 60(1), pp. 94-99.

[35] Chimack, M. J., Walker, C. E., and Miller, R., 2003, "Energy Conservation Opportunities in the Pulp and Paper Industry: An Illinois Case Study," ACEEE Technical Paper.

[36] BestPractices Case Study, 2010, "Weyerhaeuser: Compressed Air System Improvement Saves Energy and Improves Production at a Sawmill," US Department of Energy - Energy Efficiency and Renewable Energy -Industrial Technologies Program.

[37] Evaluation of Energy Efficiency Checks in Austrian Sawmills, http://www.EngineSme.eu/uploads/media/ENGINE_Country_Analysis_Austria.Pdf, 2013(November/12).

[38] AMPROBE, “Model DMII Pro," http://content.Amprobe.com/manualsA/DMII.Pdf/, 2014(April/15).

[39] Data loggers, “Onset HOBO Data Loggers," http://www.Onsetcomp.Com, 2014(April/15).

[40] Current Transducers, "Onset Split Core AC Current Sensors," http://www.Onsetcomp.Com/, 2014(April/15).

[41] McDonald, K. A., and Kretschmann, D. E., "The Encyclopedia of Wood," U.S. Department of Agriculture, pp. 1-2. Chap. 5.

[42] Cassens, D. L., "Quality Control in Lumber Purchasing: Hardwood Lumber Grades," Department of Forestry and Natural Resources, Purdue University.

[43] Sawmill and Woodlot Magazine, 2010, "Understanding Hardwood Lumber Grading,"

[44] Bond, B., 2011, "Understanding Log Scales and Log Rules," Institute of Agriculture, University of Tennessee.

[45] Taylor, A., 2009, “A Hardwood Log Grading Handbook,” Institute of Agriculture, University of Tennessee,

[46] Sandvik Wood Band Saw, "The Wood Band Saw Steels that Increase Your Profitability," http://www.Thode.Co.nz/newspdfs/1165284832_18731500.Pdf, 2014(July/7). 
[47] U.S. Department of Energy, 2007, "Determining Electric Motor Load and Efficiency," http://www1.eere.energy.gov/manufacturing/tech_assistance/pdfs/10097517.pdf, 2014(July/7).

[48] Appalachian Hardwoods, 2014, "Hardwood Market Report,"

http://www.Hmr.com/Public/Default.Aspx, 2014(July/7). 


\section{Appendix}

Table A.1: Production Details of Sawmill 1

\begin{tabular}{|c|c|c|c|c|c|c|c|c|c|c|c|c|}
\hline Date & Species & Start Time & End Time & $\begin{array}{c}\text { 4/4 Size } \\
\text { (BF) }\end{array}$ & $\begin{array}{c}5 / 4 \text { Size } \\
\text { (BF) }\end{array}$ & $\begin{array}{c}\text { 6/4 Size } \\
\text { (BF) }\end{array}$ & $\begin{array}{c}\text { 8/4 Size } \\
\text { (BF) }\end{array}$ & $\begin{array}{c}\text { Pallet } \\
\text { Material (1" } \\
\text { Thickness) } \\
\text { (BF) }\end{array}$ & $\begin{array}{c}\text { Cants }\left(5^{\prime \prime}\right. \\
\text { Thickness) } \\
\text { (BF) }\end{array}$ & $\begin{array}{c}\text { Cants (3" } \\
\text { Thickness) } \\
\text { (BF) }\end{array}$ & $\begin{array}{c}\text { Cants (3.5" } \\
\text { Thickness) } \\
\text { (BF) }\end{array}$ & $\begin{array}{l}\text { Ties (7" } \\
\text { Thick x 9" } \\
\text { Width) } \\
\text { (BF) }\end{array}$ \\
\hline $2 / 10 / 2009$ & Hickory & 6:00 AM & 10:30 AM & 4,652 & - & - & - & 252 & 2,470 & - & - & 2,767 \\
\hline $2 / 10 / 2009$ & WO & $10: 30 \mathrm{AM}$ & $2: 30 \mathrm{PM}$ & 3,783 & - & 1792 & - & 288 & 2,155 & - & - & 1,770 \\
\hline $2 / 11 / 2009$ & WO & 6:00 AM & $2: 30 \mathrm{PM}$ & 7,819 & - & 1748 & - & 734 & 4,070 & - & - & 2,470 \\
\hline $2 / 12 / 2009$ & WO & 6:00 AM & $2: 30 \mathrm{PM}$ & 10,190 & - & 288 & - & 556 & 5,080 & - & - & 3,811 \\
\hline $2 / 13 / 2009$ & WO & 6:00 AM & 9:00 AM & 3,479 & - & - & - & 496 & 1,885 & - & - & 1,982 \\
\hline $2 / 13 / 2009$ & Poplar & 9:00 AM & 1:30 PM & - & - & 5858 & - & - & 1,520 & 5,332 & - & 314 \\
\hline $2 / 16 / 2009$ & Poplar & 6:00 AM & 8:00 AM & - & - & 2598 & - & - & - & 3,994 & - & 200 \\
\hline $2 / 16 / 2009$ & Poplar & 8:00 AM & 2:30 PM & 6,689 & - & - & 1,074 & 204 & 6,660 & - & - & 3,992 \\
\hline $2 / 17 / 2009$ & RO & 6:00 AM & $2: 30 \mathrm{PM}$ & 8,761 & - & - & 760 & 3,960 & 5,210 & - & - & 3,740 \\
\hline $2 / 18 / 2009$ & RO & 6:00 AM & 2:30 PM & 7,044 & - & - & 786 & 332 & 2,390 & - & - & 5,450 \\
\hline $2 / 19 / 2009$ & $\mathrm{RO}$ & $6: 00 \mathrm{AM}$ & 2:30 PM & 8,979 & - & - & 1,138 & 348 & 2,600 & - & - & 4,993 \\
\hline $2 / 20 / 2009$ & $\mathrm{RO}$ & 6:00 AM & 11:00 AM & 5,783 & - & - & 1,144 & 284 & 1,840 & - & - & 3,074 \\
\hline $2 / 20 / 2009$ & Hickory & 11:00 AM & 1:30 PM & 1,808 & - & - & - & 44 & 675 & - & - & 2,100 \\
\hline $2 / 23 / 2009$ & Hickory & 6:00 AM & $11: 30 \mathrm{AM}$ & 5,448 & - & - & - & 258 & 1,580 & - & - & 5,524 \\
\hline $2 / 23 / 2009$ & RO & 12:00 PM & 2:30 PM & 2,731 & - & - & 392 & 108 & 825 & - & - & 2,482 \\
\hline $2 / 24 / 2009$ & RO & 6:00 AM & 2:30 PM & 8,068 & - & - & 610 & 518 & 2,515 & - & - & 6,416 \\
\hline $2 / 25 / 2009$ & $\mathrm{RO}$ & 6:00 AM & 2:30 PM & 7,882 & - & - & 1,506 & 414 & 3,945 & - & - & 4,364 \\
\hline $2 / 26 / 2009$ & RO & 6:00 AM & 2:00 PM & 8,821 & - & - & 380 & 564 & 2,945 & - & - & 3,254 \\
\hline $2 / 26 / 2009$ & WO & 2:00 PM & 2:30 PM & 534 & 69 & - & - & 10 & - & - & - & 862 \\
\hline $2 / 27 / 2009$ & WO & 6:00 AM & $1: 30 \mathrm{PM}$ & 6,795 & 1488 & - & - & 330 & 1,140 & - & - & 10,416 \\
\hline $3 / 2 / 2009$ & WO & $6: 00 \mathrm{AM}$ & $7: 45 \mathrm{AM}$ & 466 & 1188 & - & - & 28 & 185 & - & - & 1,415 \\
\hline
\end{tabular}


Table A.1: Production Details of Sawmill 1 (Cont.)

\begin{tabular}{|c|c|c|c|c|c|c|c|c|c|c|c|c|}
\hline Date & Species & Start Time & End Time & $\begin{array}{c}\text { 4/4 Size } \\
\text { (BF) }\end{array}$ & $\begin{array}{c}5 / 4 \text { Size } \\
\text { (BF) }\end{array}$ & $\begin{array}{c}\text { 6/4 Size } \\
\text { (BF) }\end{array}$ & $\begin{array}{c}\text { 8/4 Size } \\
\text { (BF) }\end{array}$ & $\begin{array}{c}\text { Pallet } \\
\text { Material (1" } \\
\text { Thickness) } \\
\text { (BF) }\end{array}$ & $\begin{array}{c}\text { Cants (5" } \\
\text { Thickness) } \\
\text { (BF) }\end{array}$ & $\begin{array}{c}\text { Cants (3” } \\
\text { Thickness) } \\
\text { (BF) }\end{array}$ & $\begin{array}{c}\text { Cants }\left(3.5^{\prime \prime}\right. \\
\text { Thickness) } \\
\text { (BF) }\end{array}$ & $\begin{array}{c}\text { Ties (7" } \\
\text { Thick x 9" } \\
\text { Width) } \\
\text { (BF) }\end{array}$ \\
\hline $3 / 2 / 2009$ & WO & 7:45 AM & 2:30 PM & - & 6,251 & - & - & 344 & 2,510 & - & - & 4,951 \\
\hline $3 / 3 / 2009$ & WO & 6:00 AM & 1:30 PM & - & 6,310 & - & - & 562 & 3,650 & - & - & 3,527 \\
\hline $3 / 3 / 2009$ & S. Maple & 1:30 PM & 2:30 PM & - & 6,92 & - & 540 & 4 & 2,40 & - & - & 651 \\
\hline $3 / 4 / 2009$ & S. Maple & 6:00 AM & 2:30 AM & - & 6,183 & - & 3918 & 488 & 3,235 & - & - & 3,695 \\
\hline $3 / 5 / 2009$ & S. Maple & 6:00 AM & 10:15 AM & - & 3,685 & - & 2014 & 456 & 3,235 & - & - & 653 \\
\hline $3 / 5 / 2009$ & RO & 10:15 AM & 2:30 PM & 5,142 & - & - & - & 178 & 1,515 & - & - & 1,475 \\
\hline $3 / 6 / 2009$ & RO & 6:00 AM & 1:30 PM & 8,507 & - & - & - & 628 & 1,630 & - & 361 & 4,601 \\
\hline $3 / 9 / 2009$ & RO & 6:00 AM & 11:30 AM & 6,395 & - & - & - & 452 & - & - & 764 & 4,303 \\
\hline $3 / 9 / 2009$ & H Maple & 11:30 AM & 2:30 PM & 4,261 & - & - & - & 100 & - & - & 322 & 1,198 \\
\hline $3 / 10 / 2009$ & H Maple & 6:00 AM & 2:30 PM & 10,666 & - & - & - & 234 & - & - & 854 & 3,494 \\
\hline $3 / 11 / 2009$ & H Maple & $6: 00 \mathrm{AM}$ & $6: 45$ AM & 729 & - & - & - & 6 & - & - & 39 & 1,391 \\
\hline $3 / 11 / 2009$ & RO & $6: 45$ AM & 2:30 PM & 1,786 & - & - & - & 798 & - & - & 1100 & 7,278 \\
\hline $3 / 12 / 2009$ & RO & 6:00 AM & 7:00 AM & 1,369 & - & - & - & 82 & - & - & 14 & 1,445 \\
\hline $3 / 12 / 2009$ & RO & 7:00 AM & 2:30 PM & 9,513 & - & - & - & 606 & - & - & 1327 & 5,639 \\
\hline
\end{tabular}


Table A.2: Production Details of Sawmill 2

\begin{tabular}{|c|c|c|c|c|c|c|c|c|c|c|}
\hline Date & Species & $\begin{array}{l}\text { Start } \\
\text { Time }\end{array}$ & End Time & $\begin{array}{c}\text { 4/4 Size } \\
\text { (BF) }\end{array}$ & $\begin{array}{c}\text { 5/4 Size } \\
\text { (BF) }\end{array}$ & $\begin{array}{c}\text { 6/4 Size } \\
\text { (BF) }\end{array}$ & $\begin{array}{c}\text { 8/4 Size } \\
\text { (BF) }\end{array}$ & $\begin{array}{c}\text { Pallet } \\
\text { Material (1" } \\
\text { Thickness) } \\
\text { (BF) }\end{array}$ & $\begin{array}{c}\text { Cants }\left(3^{\prime \prime}\right. \\
\text { Thickness) } \\
\text { (BF) }\end{array}$ & $\begin{array}{c}\text { Ties }\left(7^{\prime \prime}\right. \\
\text { Thick x 9" } \\
\text { Width) } \\
\text { (BF) }\end{array}$ \\
\hline S. Maple & $4 / 14 / 09$ & 5:30 AM & 2:45 PM & 29,726 & - & - & - & - & 1,728 & 920 \\
\hline RO & $4 / 14 / 09$ & 2:45 PM & 4:00 PM & 2,939 & - & - & 1,932 & 785 & - & - \\
\hline RO & $4 / 15 / 09$ & 5:30 AM & 4:00 PM & 18,428 & 2,897 & - & 7,888 & 3,947 & 984 & - \\
\hline $\mathrm{RO}$ & $4 / 16 / 09$ & 5:30 AM & 4:00 PM & 19,922 & 5,782 & - & - & 6,300 & 1,416 & - \\
\hline $\mathrm{RO}$ & $4 / 20 / 09$ & 5:30 AM & $9: 25 \mathrm{AM}$ & 8,557 & 1,210 & - & - & 2,421 & 312 & 875 \\
\hline WO & 4/20/09 & 9:25 AM & 4:00 PM & 13,670 & - & - & - & 5,659 & 699 & 595 \\
\hline Ash & $4 / 21 / 09$ & 5:30 AM & $9: 30 \mathrm{AM}$ & 12,053 & - & - & - & 901 & 792 & 40 \\
\hline $\mathrm{RO}$ & 4/21/09 & 9:30 AM & 4:00 PM & 12,708 & 2,424 & - & - & 2,576 & 816 & - \\
\hline WO & $4 / 22 / 09$ & 5:30 AM & $7: 30 \mathrm{AM}$ & 4,925 & 827 & - & - & 1,013 & 0 & - \\
\hline WO & $4 / 22 / 09$ & 7:30 AM & 4:00 PM & 14,722 & - & 3284 & - & 4,094 & 240 & - \\
\hline WO & $4 / 23 / 09$ & 5:30 AM & 3:00 PM & 16,521 & - & 4334 & - & 3,808 & 312 & - \\
\hline H Maple & $4 / 27 / 09$ & 5:30 AM & 4:00 PM & 22,509 & 3,890 & - & - & 3,122 & 1,320 & - \\
\hline H Maple & $4 / 28 / 09$ & 5:30 AM & 4:00 PM & 21,655 & 3,418 & - & - & 3,275 & 720 & 920 \\
\hline S. Maple & $4 / 29 / 09$ & 5:30 AM & 4:00 PM & 27,033 & - & - & - & 4,096 & 1,056 & - \\
\hline Hickory & $4 / 30 / 09$ & 5:30 AM & 9:30 AM & 7,468 & - & - & - & 1,021 & 192 & - \\
\hline WO & $4 / 30 / 09$ & 9:30 AM & 2:15 PM & 9,604 & - & - & - & 2,489 & 408 & 2,205 \\
\hline Cherry & $4 / 30 / 09$ & 2:15 PM & 4:00 PM & 2,373 & - & - & - & 964 & 120 & 315 \\
\hline Cherry & $5 / 4 / 09$ & 5:30 AM & 4:00 PM & 14,815 & - & - & - & 4,931 & 3,312 & 3,929 \\
\hline Cherry & $5 / 5 / 09$ & 5:30 AM & $8: 45 \mathrm{AM}$ & 6,238 & - & - & - & 2,577 & 480 & 196 \\
\hline $\mathrm{RO}$ & $5 / 5 / 09$ & $8: 45 \mathrm{AM}$ & 4:00 PM & 12,204 & 2,831 & - & - & 2,635 & 552 & 0 \\
\hline $\mathrm{RO}$ & $5 / 6 / 09$ & 5:30 AM & 4:00 PM & 23,998 & 301 & - & - & 4,227 & 744 & 0 \\
\hline $\mathrm{RO}$ & $5 / 7 / 09$ & 5:30 AM & 4:00 PM & 25,295 & 325 & - & - & 4,009 & 1,200 & 40 \\
\hline
\end{tabular}


Table A.3: Production Details of Sawmill 3

\begin{tabular}{|c|c|c|c|c|c|c|c|c|c|c|}
\hline Date & Species & $\begin{array}{l}\text { Start } \\
\text { Time }\end{array}$ & End Time & $\begin{array}{c}\text { 4/4 Size } \\
\text { (BF) }\end{array}$ & $\begin{array}{c}5 / 4 \text { Size } \\
\text { (BF) }\end{array}$ & $\begin{array}{c}\text { 6/4 Size } \\
\text { (BF) }\end{array}$ & $\begin{array}{c}\text { 8/4 Size } \\
\text { (BF) }\end{array}$ & $\begin{array}{c}\text { Pallet } \\
\text { Material (1" } \\
\text { Thickness) } \\
\text { (BF) }\end{array}$ & $\begin{array}{c}\text { Cants } \\
\left(3.5^{\prime \prime}\right. \\
\text { Thickness) } \\
\text { (BF) }\end{array}$ & $\begin{array}{c}\text { Ties (7" } \\
\text { Thick x 9" } \\
\text { Width) } \\
\text { (BF) }\end{array}$ \\
\hline $4 / 28 / 2014$ & $\mathrm{RO}$ & 6:00 AM & 10:00 AM & 15,602 & 4,529 & - & - & 1,778 & - & - \\
\hline $4 / 28 / 2014$ & H Maple & 10:00 AM & 4:00 PM & 23,999 & - & - & - & 2,053 & - & - \\
\hline $4 / 28 / 2014$ & H Maple & 5:00 PM & $2: 30 \mathrm{AM}$ & 28,479 & - & - & - & 3,671 & - & - \\
\hline $4 / 29 / 2014$ & H Maple & 6:00 AM & 7:30 AM & 7,017 & - & - & - & 1,143 & - & - \\
\hline $4 / 29 / 2014$ & Poplar & $7: 30 \mathrm{AM}$ & 4:00 PM & 37,240 & - & - & 12,636 & 937 & 9,975 & - \\
\hline $4 / 29 / 2014$ & Poplar & 5:00 PM & $2: 30 \mathrm{AM}$ & 42,719 & - & - & 5,782 & 1,947 & 10,698 & - \\
\hline $4 / 30 / 2014$ & Poplar & 6:00 AM & 3:30 PM & 50,940 & - & - & 11,125 & 1,063 & 11,645 & - \\
\hline $4 / 30 / 2014$ & $\mathrm{RO}$ & $3: 30 \mathrm{PM}$ & $2: 30 \mathrm{AM}$ & 36,660 & 2,807 & - & - & 3,983 & - & - \\
\hline $5 / 1 / 2014$ & RO & 6:00 AM & 4:00 PM & 36,390 & 12,699 & - & - & 6,849 & - & - \\
\hline $5 / 1 / 2014$ & RO & 5:00 PM & $2: 30 \mathrm{AM}$ & 27,376 & 5,048 & - & - & 4,683 & - & - \\
\hline $5 / 2 / 2014$ & RO & 6:00 AM & 4:00 PM & 34,148 & 6,919 & - & - & 5,592 & - & - \\
\hline $5 / 2 / 2014$ & RO & 5:00 PM & $2: 30 \mathrm{AM}$ & 30,093 & 2,398 & - & - & 4,044 & - & - \\
\hline $5 / 5 / 2014$ & $\mathrm{RO}$ & 6:00 AM & $7: 15 \mathrm{AM}$ & 6,594 & 1,471 & - & - & 748 & - & - \\
\hline $5 / 5 / 2014$ & Ash & $7: 15 \mathrm{AM}$ & $2: 45 \mathrm{PM}$ & 29,710 & - & - & 4,486 & 2,293 & - & - \\
\hline $5 / 5 / 2014$ & S. Maple & 2:45 PM & 4:00 PM & 1,885 & - & - & - & 69 & 411 & - \\
\hline $5 / 5 / 2014$ & S. Maple & 5:00 PM & $2: 30 \mathrm{AM}$ & 31,084 & - & - & - & 2,569 & 10,096 & - \\
\hline $5 / 6 / 2014$ & S. Maple & 6:00 AM & 4:00 PM & 42,391 & - & - & - & 1,455 & 11,156 & - \\
\hline $5 / 6 / 2014$ & S. Maple & $4: 30 \mathrm{PM}$ & 12:00 PM & 21,243 & - & - & - & 2,953 & 7,068 & - \\
\hline $5 / 6 / 2014$ & WO & 12:00 PM & $2: 30 \mathrm{AM}$ & - & 7,034 & - & - & 49 & - & 420 \\
\hline $5 / 7 / 2014$ & WO & 6:00 AM & 4:00 PM & - & 39,281 & - & - & 304 & - & 6,796 \\
\hline $5 / 7 / 2014$ & WO & 5:00 PM & 2:30 AM & - & 32,087 & - & - & 44 & 2,860 & 2,052 \\
\hline $5 / 8 / 2014$ & WO & 6:00 AM & 4:00 PM & - & 40,325 & - & - & 18 & - & 4,147 \\
\hline $5 / 8 / 2014$ & WO & 5:00 PM & $2: 30 \mathrm{AM}$ & - & 23,751 & - & - & 7 & 48 & 7,180 \\
\hline $5 / 9 / 2014$ & WO & 5:00 PM & $8: 30 \mathrm{PM}$ & - & 14,449 & - & - & 7 & - & 2,603 \\
\hline $5 / 9 / 2014$ & RO & 8:30 PM & $2: 30 \mathrm{AM}$ & 11,375 & 2,997 & - & - & 1,445 & - & - \\
\hline
\end{tabular}


Table A.3: Production Details of Sawmill 3 (Cont.)

\begin{tabular}{|c|c|c|c|c|c|c|c|c|c|c|}
\hline Date & Species & $\begin{array}{l}\text { Start } \\
\text { Time }\end{array}$ & End Time & $\begin{array}{c}\text { 4/4 Size } \\
\text { (BF) }\end{array}$ & $\begin{array}{c}\text { 5/4 Size } \\
\text { (BF) }\end{array}$ & $\begin{array}{c}\text { 6/4 Size } \\
\text { (BF) }\end{array}$ & $\begin{array}{c}\text { 8/4 Size } \\
\text { (BF) }\end{array}$ & $\begin{array}{c}\text { Pallet } \\
\text { Material (1" } \\
\text { Thickness) } \\
\text { (BF) }\end{array}$ & $\begin{array}{c}\text { Cants } \\
(3.5 " \\
\text { Thickness) } \\
\text { (BF) }\end{array}$ & $\begin{array}{c}\text { Ties (7" } \\
\text { Thick x 9" } \\
\text { Width) } \\
\text { (BF) }\end{array}$ \\
\hline $5 / 10 / 2014$ & RO & 6:00 AM & $2: 30 \mathrm{PM}$ & 33,057 & 1,516 & - & - & 3,875 & - & 1,834 \\
\hline $5 / 12 / 2014$ & RO & 6:00 AM & $6: 45 \mathrm{AM}$ & 5,014 & 506 & - & - & 480 & - & - \\
\hline $5 / 12 / 2014$ & H Maple & 6:45 AM & 4:00 PM & 33,810 & - & - & - & 2,644 & - & - \\
\hline $5 / 12 / 2014$ & H Maple & 5:00 PM & $2: 30 \mathrm{AM}$ & 21,115 & - & - & - & 2,088 & 4,326 & - \\
\hline
\end{tabular}




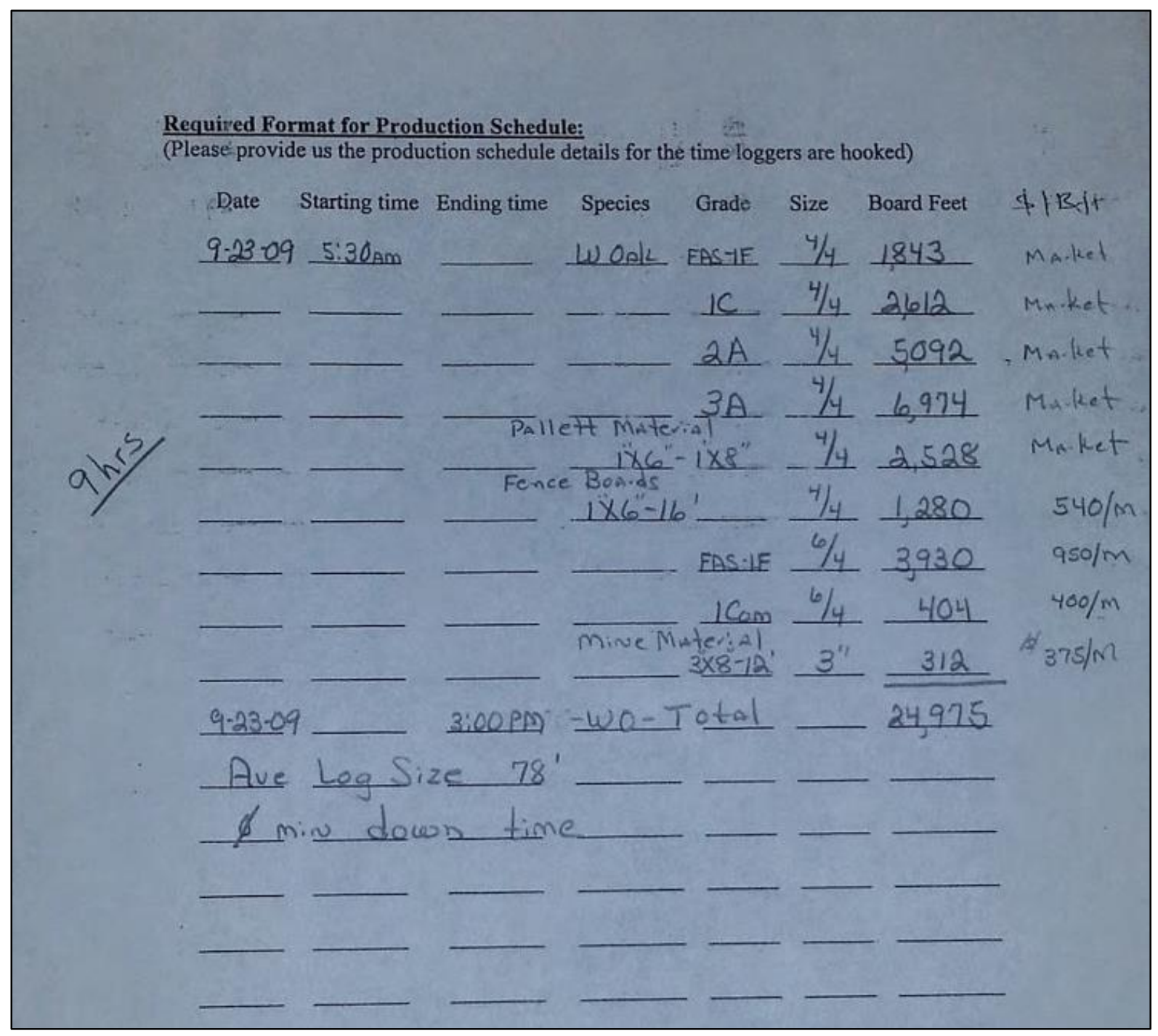

Figure A.1: Sample of Production Data Questionnaire 
Table A.4: Load Factors (\%) of Motors in Sawmill 2

\begin{tabular}{|c|c|c|c|c|c|c|c|c|c|c|c|c|c|c|}
\hline Shift & $\begin{array}{c}\text { Head } \\
\text { Saw }\end{array}$ & $\begin{array}{l}\text { Re- } \\
\text { saw }\end{array}$ & Edger & Trimmer & Chipper & Debarker & $\begin{array}{c}\text { Compressor } \\
1\end{array}$ & $\begin{array}{c}\text { Compressor } \\
\mathbf{3}\end{array}$ & $\begin{array}{l}\text { Top } \\
\text { Saw }\end{array}$ & $\begin{array}{c}\text { Log } \\
\text { turner }\end{array}$ & $\begin{array}{c}\text { Dust } \\
\text { Collector }\end{array}$ & $\begin{array}{c}\text { Carriage } \\
\text { Feed } \\
\text { Motor }\end{array}$ & $\begin{array}{c}\text { Chip } \\
\text { Blower }\end{array}$ & $\begin{array}{l}\text { Other } \\
\text { Motors }\end{array}$ \\
\hline 1 & 0.13 & 0.11 & 0.14 & 0.14 & 0.15 & 0.55 & 1.10 & 1.05 & 0.15 & 0.24 & 0.89 & 0.29 & 0.93 & 0.45 \\
\hline 2 & 0.13 & 0.12 & 0.15 & 0.14 & 0.16 & 0.57 & 1.12 & 1.06 & 0.48 & 0.22 & 0.87 & 0.28 & 0.91 & 0.48 \\
\hline 3 & 0.12 & 0.12 & 0.14 & 0.13 & 0.16 & 0.60 & 1.12 & 1.09 & 0.15 & 0.22 & 0.88 & 0.28 & 0.93 & 0.46 \\
\hline 4 & 0.13 & 0.12 & 0.14 & 0.13 & 0.16 & 0.56 & 1.13 & 1.09 & 0.15 & 0.22 & 0.87 & 0.29 & 0.93 & 0.46 \\
\hline 5 & 0.13 & 0.12 & 0.15 & 0.13 & 0.15 & 0.56 & 1.08 & 1.04 & 0.15 & 0.23 & 0.87 & 0.29 & 0.91 & 0.45 \\
\hline 6 & 0.13 & 0.12 & 0.15 & 0.14 & 0.15 & 0.62 & 1.05 & 1.00 & 0.15 & 0.23 & 0.88 & 0.29 & 0.88 & 0.45 \\
\hline 7 & 0.13 & 0.13 & 0.15 & 0.14 & 0.15 & 0.65 & 1.09 & 1.04 & 0.15 & 0.23 & 0.88 & 0.30 & 0.94 & 0.46 \\
\hline 8 & 0.13 & 0.12 & 0.15 & 0.14 & 0.15 & 0.62 & 1.11 & 1.05 & 0.15 & 0.22 & 0.88 & 0.28 & 0.93 & 0.46 \\
\hline 9 & 0.12 & 0.11 & 0.14 & 0.14 & 0.15 & 0.63 & 1.16 & 1.10 & 0.15 & 0.24 & 0.87 & 0.30 & 0.95 & 0.47 \\
\hline 10 & 0.13 & 0.12 & 0.15 & 0.14 & 0.15 & 0.63 & 1.13 & 1.07 & 0.15 & 0.23 & 0.89 & 0.30 & 0.94 & 0.46 \\
\hline 11 & 0.12 & 0.11 & 0.14 & 0.14 & 0.15 & 0.59 & 1.12 & 1.06 & 0.15 & 0.22 & 0.87 & 0.28 & 0.94 & 0.45 \\
\hline 12 & 0.12 & 0.12 & 0.15 & 0.14 & 0.15 & 0.55 & 1.06 & 1.02 & 0.15 & 0.22 & 0.88 & 0.28 & 0.91 & 0.44 \\
\hline 13 & 0.12 & 0.12 & 0.14 & 0.14 & 0.15 & 0.56 & 1.10 & 1.05 & 0.15 & 0.22 & 0.88 & 0.29 & 0.91 & 0.45 \\
\hline 14 & 0.12 & 0.11 & 0.14 & 0.14 & 0.14 & 0.50 & 1.11 & 1.06 & 0.15 & 0.23 & 0.87 & 0.28 & 0.92 & 0.44 \\
\hline 15 & 0.13 & 0.12 & 0.14 & 0.14 & 0.14 & 0.54 & 1.13 & 1.09 & 0.15 & 0.23 & 0.86 & 0.27 & 0.93 & 0.45 \\
\hline 16 & 0.14 & 0.11 & 0.14 & 0.14 & 0.15 & 0.53 & 1.11 & 1.05 & 0.15 & 0.22 & 0.88 & 0.29 & 0.92 & 0.45 \\
\hline 17 & 0.11 & 0.10 & 0.14 & 0.14 & 0.15 & 0.44 & 1.13 & 1.06 & 0.15 & 0.22 & 0.87 & 0.26 & 0.90 & 0.44 \\
\hline 18 & 0.13 & 0.10 & 0.14 & 0.14 & 0.13 & 0.50 & 1.11 & 1.06 & 0.15 & 0.22 & 0.87 & 0.30 & 0.91 & 0.44 \\
\hline 19 & 0.11 & 0.12 & 0.15 & 0.14 & 0.14 & 0.52 & 1.11 & 1.06 & 0.15 & 0.23 & 0.87 & 0.29 & 0.93 & 0.45 \\
\hline 20 & 0.12 & 0.11 & 0.14 & 0.14 & 0.15 & 0.48 & 1.12 & 1.07 & 0.15 & 0.21 & 0.87 & 0.29 & 0.92 & 0.44 \\
\hline 21 & 0.12 & 0.12 & 0.14 & 0.14 & 0.15 & 0.51 & 1.11 & 1.06 & 0.15 & 0.21 & 0.87 & 0.28 & 0.91 & 0.44 \\
\hline 22 & 0.12 & 0.12 & 0.14 & 0.14 & 0.15 & 0.52 & 1.11 & 1.05 & 0.15 & 0.22 & 0.85 & 0.29 & 0.91 & 0.44 \\
\hline
\end{tabular}


Table A.5: Load Factors (\%) of Motors in Sawmill 3

\begin{tabular}{|c|c|c|c|c|c|c|c|c|c|c|c|c|c|c|c|}
\hline Shift & $\begin{array}{l}\text { Main } \\
\text { Saw }\end{array}$ & $\begin{array}{l}\text { Re- } \\
\text { saw }\end{array}$ & Edger & Trimmer & $\begin{array}{l}\text { Gang } \\
\text { Saw }\end{array}$ & Debarker & $\begin{array}{c}\text { Debarker } \\
\text { Hydraulic } \\
\text { Motor }\end{array}$ & Chipper & $\begin{array}{c}\text { Compressor } \\
1\end{array}$ & $\begin{array}{c}\text { Compressor } \\
2\end{array}$ & $\begin{array}{c}\text { Compressor } \\
\mathbf{3}\end{array}$ & $\begin{array}{c}\text { Log } \\
\text { Turner }\end{array}$ & $\begin{array}{c}\text { Log } \\
\text { Deck } \\
\text { Motor }\end{array}$ & $\begin{array}{c}\text { Line } \\
\text { Bar } \\
\text { Motor }\end{array}$ & $\begin{array}{l}\text { Other } \\
\text { Motors }\end{array}$ \\
\hline 1 & 0.57 & 0.53 & 0.60 & 0.70 & 0.95 & 0.24 & 0.14 & 0.26 & 0.29 & 0.33 & 0.59 & 0.57 & 0.98 & 0.27 & 0.50 \\
\hline 2 & 0.57 & 0.53 & 0.60 & 0.71 & 0.97 & 0.24 & 0.14 & 0.26 & 0.29 & 0.33 & 0.59 & 0.55 & 0.96 & 0.28 & 0.50 \\
\hline 3 & 0.53 & 0.52 & 0.60 & 0.68 & 0.95 & 0.24 & 0.14 & 0.26 & 0.30 & 0.34 & 0.61 & 0.60 & 0.99 & 0.27 & 0.50 \\
\hline 4 & 0.55 & 0.52 & 0.60 & 0.69 & 0.95 & 0.24 & 0.14 & 0.26 & 0.29 & 0.33 & 0.60 & 0.56 & 0.97 & 0.27 & 0.50 \\
\hline 5 & 0.56 & 0.51 & 0.60 & 0.68 & 0.92 & 0.25 & 0.14 & 0.26 & 0.29 & 0.33 & 0.59 & 0.54 & 0.98 & 0.28 & 0.49 \\
\hline 6 & 0.55 & 0.52 & 0.60 & 0.70 & 0.92 & 0.25 & 0.14 & 0.26 & 0.29 & 0.33 & 0.59 & 0.58 & 0.99 & 0.27 & 0.50 \\
\hline 7 & 0.56 & 0.55 & 0.60 & 0.70 & 0.92 & 0.25 & 0.14 & 0.26 & 0.29 & 0.32 & 0.58 & 0.55 & 0.99 & 0.28 & 0.50 \\
\hline 8 & 0.56 & 0.52 & 0.60 & 0.70 & 0.89 & 0.24 & 0.14 & 0.26 & 0.30 & 0.33 & 0.60 & 0.59 & 0.98 & 0.28 & 0.50 \\
\hline 9 & 0.57 & 0.59 & 0.60 & 0.68 & 0.97 & 0.24 & 0.14 & 0.26 & 0.29 & 0.32 & 0.58 & 0.57 & 0.98 & 0.27 & 0.50 \\
\hline 10 & 0.56 & 0.51 & 0.60 & 0.70 & 0.95 & 0.24 & 0.14 & 0.26 & 0.29 & 0.32 & 0.59 & 0.59 & 0.98 & 0.27 & 0.50 \\
\hline 11 & 0.55 & 0.55 & 0.60 & 0.70 & 0.98 & 0.24 & 0.14 & 0.25 & 0.29 & 0.32 & 0.58 & 0.56 & 0.98 & 0.27 & 0.50 \\
\hline 12 & 0.55 & 0.50 & 0.60 & 0.70 & 0.96 & 0.24 & 0.14 & 0.26 & 0.29 & 0.32 & 0.59 & 0.58 & 0.98 & 0.27 & 0.50 \\
\hline 13 & 0.57 & 0.58 & 0.61 & 0.70 & 0.93 & 0.24 & 0.15 & 0.25 & 0.30 & 0.32 & 0.60 & 0.59 & 1.01 & 0.27 & 0.51 \\
\hline 14 & 0.55 & 0.57 & 0.61 & 0.70 & 0.99 & 0.24 & 0.14 & 0.26 & 0.29 & 0.32 & 0.58 & 0.55 & 0.97 & 0.27 & 0.50 \\
\hline 15 & 0.55 & 0.51 & 0.62 & 0.71 & 0.99 & 0.24 & 0.14 & 0.26 & 0.30 & 0.33 & 0.58 & 0.53 & 0.98 & 0.28 & 0.50 \\
\hline 16 & 0.55 & 0.49 & 0.61 & 0.70 & 0.95 & 0.24 & 0.14 & 0.25 & 0.29 & 0.32 & 0.59 & 0.57 & 0.98 & 0.28 & 0.50 \\
\hline 17 & 0.56 & 0.51 & 0.60 & 0.71 & 0.94 & 0.24 & 0.14 & 0.25 & 0.29 & 0.33 & 0.58 & 0.53 & 0.97 & 0.28 & 0.49 \\
\hline 18 & 0.54 & 0.49 & 0.59 & 0.70 & 0.93 & 0.24 & 0.14 & 0.25 & 0.30 & 0.33 & 0.60 & 0.55 & 0.97 & 0.28 & 0.49 \\
\hline 19 & 0.55 & 0.46 & 0.61 & 0.68 & 0.95 & 0.24 & 0.14 & 0.26 & 0.31 & 0.34 & 0.61 & 0.56 & 0.97 & 0.28 & 0.50 \\
\hline 20 & 0.56 & 0.53 & 0.60 & 0.70 & 0.94 & 0.24 & 0.14 & 0.26 & 0.29 & 0.32 & 0.58 & 0.54 & 0.98 & 0.28 & 0.50 \\
\hline 21 & 0.55 & 0.47 & 0.60 & 0.70 & 0.96 & 0.24 & 0.14 & 0.26 & 0.30 & 0.33 & 0.59 & 0.56 & 0.99 & 0.29 & 0.50 \\
\hline 22 & 0.56 & 0.54 & 0.60 & 0.71 & 0.94 & 0.24 & 0.14 & 0.26 & 0.29 & 0.33 & 0.58 & 0.55 & 0.98 & 0.28 & 0.50 \\
\hline 23 & 0.52 & 0.46 & 0.60 & 0.71 & 0.95 & 0.24 & 0.14 & 0.27 & 0.30 & 0.33 & 0.60 & 0.57 & 0.99 & 0.28 & 0.50 \\
\hline 24 & 0.55 & 0.44 & 0.58 & 0.70 & 0.92 & 0.24 & 0.14 & 0.26 & 0.31 & 0.34 & 0.60 & 0.56 & 0.99 & 0.28 & 0.49 \\
\hline 25 & 0.03 & 0.50 & 0.60 & 0.76 & 0.93 & 0.24 & 0.14 & 0.27 & 0.30 & 0.33 & 0.60 & 0.56 & 0.98 & 0.28 & 0.47 \\
\hline
\end{tabular}


Table A.5: Load Factors (\%) of Motors in Sawmill 3 (Cont.)

\begin{tabular}{|c|c|c|c|c|c|c|c|c|c|c|c|c|c|c|c|}
\hline Shift & $\begin{array}{c}\text { Main } \\
\text { Saw }\end{array}$ & $\begin{array}{l}\text { Re- } \\
\text { saw }\end{array}$ & Edger & Trimmer & $\begin{array}{l}\text { Gang } \\
\text { Saw }\end{array}$ & Debarker & $\begin{array}{c}\text { Debarker } \\
\text { Hydraulic } \\
\text { Motor }\end{array}$ & Chipper & $\begin{array}{c}\text { Compressor } \\
1\end{array}$ & $\begin{array}{c}\text { Compressor } \\
2\end{array}$ & $\begin{array}{c}\text { Compressor } \\
\mathbf{3}\end{array}$ & $\begin{array}{c}\text { Log } \\
\text { Turner }\end{array}$ & $\begin{array}{c}\text { Log } \\
\text { Deck } \\
\text { Motor }\end{array}$ & $\begin{array}{l}\text { Line } \\
\text { Bar } \\
\text { Motor }\end{array}$ & $\begin{array}{l}\text { Other } \\
\text { Motors }\end{array}$ \\
\hline 26 & 0.57 & 0.54 & 0.60 & 0.70 & 0.97 & 0.24 & 0.14 & 0.26 & 0.30 & 0.32 & 0.59 & 0.57 & 1.00 & 0.27 & 0.51 \\
\hline 27 & 0.57 & 0.50 & 0.59 & 0.70 & 0.93 & 0.24 & 0.15 & 0.25 & 0.29 & 0.34 & 0.60 & 0.61 & 1.01 & 0.27 & 0.50 \\
\hline 28 & 0.56 & 0.56 & 0.61 & 0.71 & 0.97 & 0.24 & 0.14 & 0.26 & 0.29 & 0.34 & 0.59 & 0.53 & 0.98 & 0.28 & 0.50 \\
\hline 29 & 0.55 & 0.49 & 0.60 & 0.71 & 0.98 & 0.24 & 0.14 & 0.26 & 0.31 & 0.34 & 0.61 & 0.54 & 0.99 & 0.28 & 0.50 \\
\hline
\end{tabular}


Table A.6: Energy Consumption of Motors in Sawmill 1

\begin{tabular}{|c|c|c|c|c|c|c|c|c|c|c|}
\hline Shift & $\begin{array}{c}\text { Main } \\
\text { Saw } \\
(\mathbf{k W h})\end{array}$ & $\begin{array}{c}\text { Carriage } \\
\text { Motor } \\
\text { (kWh) }\end{array}$ & $\begin{array}{l}\text { Edger } \\
(\mathbf{k W h})\end{array}$ & $\begin{array}{c}\text { Trimmer } \\
(\mathrm{kWh})\end{array}$ & $\begin{array}{c}\text { Compressor } \\
(\mathbf{k W h})\end{array}$ & $\begin{array}{c}\text { Chipper } \\
(\mathbf{k W h})\end{array}$ & $\begin{array}{c}\text { Debarker } \\
\text { (kWh) }\end{array}$ & $\begin{array}{l}\text { Chip Bin } \\
\text { (kWh) }\end{array}$ & $\begin{array}{c}\text { Barn } \\
\text { Sweep } \\
\text { Motor } \\
\text { (kWh) }\end{array}$ & $\begin{array}{c}\text { Conveyor } \\
(\mathbf{k W h})\end{array}$ \\
\hline 1 & 228.07 & 94.79 & 33.03 & 33.38 & 121.18 & 133.98 & 228.99 & 13.20 & 5.29 & 11.92 \\
\hline 2 & 167.22 & 78.07 & 26.83 & 27.49 & 99.47 & 123.78 & 172.04 & 13.23 & 4.99 & 11.11 \\
\hline 3 & 367.00 & 172.86 & 58.35 & 60.88 & 235.01 & 251.96 & 330.71 & 24.65 & 10.49 & 23.23 \\
\hline 4 & 386.43 & 172.86 & 55.99 & 60.88 & 229.43 & 258.14 & 354.59 & 33.18 & 9.82 & 22.12 \\
\hline 5 & 155.89 & 66.91 & 21.80 & 23.56 & 94.32 & 91.48 & 122.55 & 8.78 & 3.24 & 7.46 \\
\hline 6 & 177.05 & 83.64 & 28.13 & 29.46 & 111.53 & 140.08 & 144.81 & 17.68 & 5.19 & 11.85 \\
\hline 7 & 110.59 & 44.61 & 16.47 & 15.71 & 64.28 & 68.52 & 81.73 & 6.59 & 2.32 & 5.15 \\
\hline 8 & 275.70 & 128.25 & 42.69 & 45.17 & 166.23 & 196.74 & 226.17 & 25.68 & 7.89 & 17.37 \\
\hline 9 & 387.60 & 172.86 & 59.70 & 60.88 & 239.73 & 257.11 & 334.37 & 25.74 & 10.27 & 22.83 \\
\hline 10 & 371.09 & 172.86 & 56.24 & 60.88 & 238.68 & 239.69 & 299.04 & 32.56 & 10.48 & 22.83 \\
\hline 11 & 385.85 & 172.86 & 58.23 & 60.88 & 238.72 & 256.74 & 306.42 & 24.53 & 10.43 & 23.01 \\
\hline 12 & 244.05 & 105.95 & 37.24 & 37.31 & 148.76 & 153.85 & 219.27 & 14.51 & 5.86 & 13.09 \\
\hline 13 & 84.11 & 44.61 & 14.16 & 15.71 & 66.38 & 80.24 & 112.24 & 7.69 & 3.19 & 6.84 \\
\hline 14 & 280.46 & 117.10 & 42.05 & 41.24 & 159.71 & 167.97 & 267.81 & 18.32 & 6.43 & 14.35 \\
\hline 15 & 113.91 & 55.76 & 18.50 & 19.64 & 80.34 & 87.25 & 99.11 & 14.33 & 3.79 & 8.41 \\
\hline 16 & 380.80 & 172.86 & 59.92 & 60.88 & 239.18 & 275.95 & 348.44 & 32.41 & 10.61 & 23.72 \\
\hline 17 & 386.42 & 172.86 & 60.05 & 60.88 & 239.46 & 253.15 & 300.02 & 25.32 & 10.23 & 22.67 \\
\hline 18 & 364.79 & 161.71 & 55.88 & 56.95 & 223.15 & 233.56 & 304.14 & 26.99 & 9.72 & 21.43 \\
\hline 19 & 21.64 & 11.15 & 3.47 & 3.93 & 15.01 & 17.96 & 24.30 & 1.62 & 0.79 & 1.72 \\
\hline 20 & 349.40 & 150.55 & 54.40 & 53.02 & 213.20 & 236.58 & 287.01 & 22.33 & 9.53 & 20.74 \\
\hline 21 & 96.90 & 39.03 & 13.35 & 13.75 & 64.61 & 49.95 & 63.72 & 5.14 & 2.04 & 4.62 \\
\hline 22 & 280.85 & 133.83 & 48.82 & 47.13 & 175.22 & 206.25 & 258.86 & 31.16 & 8.04 & 17.88 \\
\hline 23 & 332.25 & 150.55 & 53.57 & 53.02 & 206.74 & 249.25 & 317.82 & 31.13 & 8.73 & 19.56 \\
\hline 24 & 37.65 & 22.30 & 7.66 & 7.85 & 24.94 & 32.16 & 33.28 & 4.54 & 1.24 & 2.71 \\
\hline
\end{tabular}


Table A.6: Energy Consumption of Motors in Sawmill 1 (Cont.)

\begin{tabular}{|c|c|c|c|c|c|c|c|c|c|c|}
\hline Shift & $\begin{array}{c}\text { Main } \\
\text { Saw } \\
(\mathbf{k W h})\end{array}$ & $\begin{array}{c}\text { Carriage } \\
\text { Motor } \\
\text { (kWh) }\end{array}$ & $\begin{array}{l}\text { Edger } \\
(\mathbf{k W h})\end{array}$ & $\begin{array}{c}\text { Trimmer } \\
(\mathbf{k W h})\end{array}$ & $\begin{array}{c}\text { Compressor } \\
(\mathbf{k W h})\end{array}$ & $\begin{array}{c}\text { Chipper } \\
(\mathbf{k W h})\end{array}$ & $\begin{array}{c}\text { Debarker } \\
(\mathrm{kWh})\end{array}$ & $\begin{array}{c}\text { Chip Bin } \\
(\mathbf{k W h})\end{array}$ & $\begin{array}{c}\text { Barn } \\
\text { Sweep } \\
\text { Motor } \\
\text { (kWh) }\end{array}$ & $\begin{array}{c}\text { Conveyor } \\
(\mathbf{k W h})\end{array}$ \\
\hline 25 & 351.61 & 172.86 & 60.36 & 60.88 & 246.15 & 266.99 & 300.85 & 36.44 & 10.34 & 23.08 \\
\hline 26 & 209.04 & 89.22 & 31.08 & 31.42 & 126.07 & 139.59 & 152.38 & 13.56 & 4.94 & 11.10 \\
\hline 27 & 179.35 & 83.64 & 28.90 & 29.46 & 102.10 & 127.28 & 135.21 & 17.78 & 5.27 & 11.69 \\
\hline 28 & 307.06 & 150.55 & 47.31 & 53.02 & 207.51 & 233.05 & 234.40 & 22.18 & 9.39 & 20.59 \\
\hline 29 & 267.81 & 117.10 & 39.93 & 41.24 & 156.05 & 172.00 & 216.47 & 17.38 & 6.72 & 14.81 \\
\hline 30 & 143.99 & 55.76 & 19.30 & 19.64 & 76.92 & 86.54 & 90.41 & 13.41 & 3.90 & 8.52 \\
\hline 31 & 359.69 & 172.86 & 60.57 & 60.88 & 234.63 & 262.24 & 316.25 & 26.50 & 10.38 & 22.91 \\
\hline 32 & 48.84 & 16.73 & 6.15 & 5.89 & 35.72 & 21.11 & 32.96 & 2.11 & 0.90 & 2.01 \\
\hline 33 & 338.03 & 156.13 & 55.37 & 54.98 & 196.52 & 228.32 & 285.37 & 25.41 & 9.73 & 21.18 \\
\hline 34 & 68.35 & 44.61 & 7.75 & 7.85 & 47.04 & 34.88 & 43.31 & 3.49 & 1.17 & 2.62 \\
\hline 35 & 320.29 & 150.55 & 54.53 & 53.02 & 195.24 & 221.47 & 329.40 & 21.99 & 9.09 & 19.95 \\
\hline
\end{tabular}


Table A.7: Energy Consumption of Motors in Sawmill 2

\begin{tabular}{|c|c|c|c|c|c|c|c|c|c|c|c|c|c|c|}
\hline Shift & $\begin{array}{c}\text { Head } \\
\text { Saw } \\
(\mathbf{k W h})\end{array}$ & $\begin{array}{c}\text { Re- } \\
\text { saw } \\
(\mathbf{k W h})\end{array}$ & $\begin{array}{l}\text { Edger } \\
(\mathrm{kWh})\end{array}$ & $\begin{array}{c}\text { Trimmer } \\
(\mathbf{k W h})\end{array}$ & $\begin{array}{c}\text { Chipper } \\
(\mathrm{kWh})\end{array}$ & $\begin{array}{c}\text { Debarker } \\
(\mathbf{k W h})\end{array}$ & $\begin{array}{c}\text { Compressor } \\
1 \\
(\mathbf{k W h})\end{array}$ & $\begin{array}{c}\text { Compressor } \\
\mathbf{3} \\
(\mathbf{k W h})\end{array}$ & $\begin{array}{c}\text { Top } \\
\text { Saw } \\
(\mathbf{k W h})\end{array}$ & $\begin{array}{c}\text { Log } \\
\text { turner } \\
(\mathbf{k W h})\end{array}$ & $\begin{array}{c}\text { Dust } \\
\text { Collector } \\
(\mathbf{k W h})\end{array}$ & $\begin{array}{l}\text { Carriage } \\
\text { Feed } \\
\text { Motor } \\
(\mathrm{kWh})\end{array}$ & $\begin{array}{c}\text { Chip } \\
\text { Blower } \\
(\text { kWh })\end{array}$ & $\begin{array}{c}\text { Other } \\
\text { Motors } \\
(\mathrm{kWh})\end{array}$ \\
\hline 1 & 39.30 & 43.78 & 8.50 & 7.57 & 228.32 & 58.03 & 92.41 & 217.77 & 176.95 & 192.44 & 159.15 & 74.41 & 152.69 & 635.50 \\
\hline 2 & 6.67 & 7.08 & 1.31 & 4.79 & 31.36 & 8.27 & 14.19 & 29.74 & 21.48 & 27.81 & 23.91 & 7.73 & 19.61 & 121.23 \\
\hline 3 & 49.05 & 54.17 & 9.70 & 40.17 & 263.10 & 65.93 & 116.64 & 283.52 & 188.64 & 245.08 & 207.36 & 80.28 & 172.42 & 937.80 \\
\hline 4 & 50.06 & 52.98 & 9.70 & 34.38 & 264.80 & 64.84 & 122.64 & 285.82 & 200.66 & 246.44 & 209.48 & 225.52 & 181.19 & 937.80 \\
\hline 5 & 19.19 & 20.61 & 3.78 & 9.54 & 94.75 & 26.02 & 49.27 & 114.55 & 78.85 & 100.60 & 82.20 & 26.57 & 71.11 & 363.68 \\
\hline 6 & 31.30 & 33.38 & 6.14 & 3.25 & 154.63 & 39.73 & 74.50 & 128.64 & 124.65 & 139.06 & 121.98 & 55.05 & 113.68 & 574.12 \\
\hline 7 & 21.45 & 21.39 & 4.01 & 8.74 & 97.59 & 26.76 & 51.62 & 118.54 & 81.43 & 108.50 & 83.12 & 30.96 & 72.15 & 371.43 \\
\hline 8 & 29.70 & 32.42 & 6.22 & 13.14 & 161.81 & 38.94 & 70.96 & 152.19 & 114.36 & 136.92 & 109.73 & 47.65 & 107.34 & 565.39 \\
\hline 9 & 9.94 & 12.33 & 2.19 & 8.68 & 52.44 & 15.68 & 30.33 & 76.58 & 43.12 & 65.14 & 50.82 & 14.59 & 35.88 & 193.96 \\
\hline 10 & 37.28 & 42.21 & 8.18 & 23.90 & 212.27 & 50.32 & 94.40 & 203.55 & 159.46 & 200.54 & 163.23 & 65.58 & 138.73 & 743.84 \\
\hline 11 & 37.73 & 45.84 & 9.05 & 30.20 & 208.44 & 56.36 & 110.43 & 236.47 & 173.94 & 224.96 & 176.25 & 60.64 & 155.31 & 840.82 \\
\hline 12 & 50.97 & 55.17 & 10.36 & 7.95 & 249.96 & 64.33 & 118.14 & 205.20 & 197.76 & 240.20 & 197.45 & 75.53 & 174.50 & 937.80 \\
\hline 13 & 48.74 & 52.05 & 10.12 & 14.02 & 258.84 & 60.51 & 121.07 & 269.77 & 192.28 & 247.08 & 206.63 & 79.86 & 165.24 & 937.80 \\
\hline 14 & 43.95 & 49.32 & 10.12 & 17.60 & 260.98 & 60.23 & 118.72 & 275.76 & 180.28 & 243.00 & 191.26 & 71.74 & 162.74 & 937.80 \\
\hline 15 & 14.38 & 15.97 & 3.89 & 2.81 & 101.22 & 17.98 & 50.14 & 126.68 & 46.79 & 107.85 & 80.80 & 22.11 & 48.28 & 371.43 \\
\hline 16 & 20.41 & 22.03 & 4.25 & 13.52 & 118.10 & 26.73 & 46.98 & 111.81 & 85.83 & 97.48 & 79.25 & 35.84 & 80.63 & 395.68 \\
\hline 17 & 8.11 & 9.34 & 1.87 & 5.35 & 44.44 & 11.34 & 20.09 & 41.52 & 31.93 & 38.46 & 31.38 & 7.45 & 28.74 & \begin{tabular}{|l|}
169.72 \\
\end{tabular} \\
\hline 18 & 41.68 & 52.62 & 10.13 & 32.34 & 260.31 & 62.57 & 117.68 & 275.82 & 211.31 & 243.78 & 179.46 & 57.25 & 179.76 & 937.80 \\
\hline 19 & 17.08 & 17.40 & 3.45 & 11.44 & 81.45 & 21.13 & 41.99 & 104.23 & 63.75 & 89.58 & 69.59 & 18.89 & 51.21 & 315.19 \\
\hline 20 & 32.00 & 35.39 & 6.71 & 20.18 & 182.19 & 37.68 & 73.25 & 173.10 & 127.22 & 152.34 & 121.38 & 35.01 & 107.38 & 622.61 \\
\hline 21 & 44.67 & 52.38 & 10.08 & 34.74 & 261.76 & 59.52 & 117.38 & 273.62 & 193.54 & 241.24 & 197.15 & 67.97 & 164.79 & 937.80 \\
\hline 22 & 50.70 & 51.59 & 10.01 & 37.98 & 262.00 & 60.83 & 120.91 & 275.28 & 193.03 & 243.20 & 203.84 & 69.99 & 166.49 & 937.80 \\
\hline
\end{tabular}


Table A.8: Energy Consumption of Motors in Sawmill 3

\begin{tabular}{|c|c|c|c|c|c|c|c|c|c|c|c|c|c|c|c|}
\hline Shift & $\begin{array}{c}\text { Main } \\
\text { Saw } \\
(\mathbf{k W h})\end{array}$ & $\begin{array}{c}\text { Re- } \\
\text { saw } \\
\text { (kWh) }\end{array}$ & $\begin{array}{l}\text { Edger } \\
(\mathrm{kWh})\end{array}$ & $\begin{array}{c}\text { Trimmer } \\
(\mathbf{k W h})\end{array}$ & $\begin{array}{c}\text { Gang } \\
\text { Saw } \\
(\mathbf{k W h})\end{array}$ & $\begin{array}{c}\text { Debarker } \\
(\mathbf{k W h})\end{array}$ & $\begin{array}{c}\text { Debarker } \\
\text { Hydraulic } \\
\text { Motor } \\
\text { (kWh) }\end{array}$ & $\begin{array}{c}\text { Chipper } \\
\text { (kWh) }\end{array}$ & $\begin{array}{c}\text { Compressor } \\
1 \\
(\mathbf{k W h})\end{array}$ & $\begin{array}{c}\text { Compressor } \\
2 \\
(\mathbf{k W h})\end{array}$ & $\begin{array}{c}\text { Compressor } \\
\mathbf{3} \\
(\mathbf{k W h})\end{array}$ & $\begin{array}{c}\text { Log } \\
\text { Turner } \\
(\mathbf{k W h})\end{array}$ & \begin{tabular}{|c|} 
Log \\
Deck \\
Motor \\
$(\mathbf{k W h})$
\end{tabular} & \begin{tabular}{|c|} 
Line \\
Bar \\
Motor \\
(kWh)
\end{tabular} & $\begin{array}{c}\text { Other } \\
\text { Motors } \\
(\mathbf{k W h})\end{array}$ \\
\hline 1 & 266.68 & 87.57 & 232.06 & 477.78 & 303.62 & 14.46 & 80.85 & 262.02 & 98.02 & 109.84 & 198.85 & 38.55 & 65.77 & 9.18 & 79.88 \\
\hline 2 & 339.09 & 128.20 & 318.84 & 545.60 & 367.88 & 16.34 & 93.87 & 338.22 & 140.02 & 160.84 & 284.08 & 42.44 & 73.99 & 12.11 & 102.09 \\
\hline 3 & 562.24 & 217.25 & 449.13 & 962.84 & 597.87 & 31.03 & 175.96 & 559.34 & 236.07 & 263.08 & 473.85 & 85.33 & 138.03 & 19.97 & 174.48 \\
\hline 4 & 118.43 & 53.16 & 119.75 & 211.62 & 171.41 & 6.81 & 38.25 & 119.95 & 47.81 & 53.76 & 97.60 & 14.64 & 25.37 & 5.29 & 38.56 \\
\hline 5 & 465.75 & 169.75 & 383.32 & 825.05 & 523.28 & 23.85 & 132.06 & 444.43 & 194.82 & 221.10 & 393.36 & 63.96 & 115.81 & 17.10 & 142.05 \\
\hline 6 & 550.47 & 228.60 & 525.90 & $1,014.08$ & 694.61 & 30.47 & 163.05 & 603.31 & 229.79 & 258.20 & 463.86 & 85.22 & 144.57 & 19.18 & 178.11 \\
\hline 7 & 584.71 & 214.67 & 534.28 & 992.76 & 643.64 & 29.61 & 169.84 & 573.25 & 218.88 & 248.66 & 442.07 & 76.79 & 139.42 & 21.25 & 174.35 \\
\hline 8 & 636.66 & 238.55 & 554.84 & $1,110.42$ & 734.73 & 32.39 & .67 & 641.41 & 255.35 & 282.33 & 511.65 & 88.96 & 148.90 & 21.67 & 192.33 \\
\hline 9 & 660.73 & 237.00 & 570.07 & $1,033.93$ & 746.90 & 31.44 & 173.42 & 605.39 & 242.28 & 269.25 & 488.00 & 83.50 & 142.81 & 21.71 & 188.74 \\
\hline 10 & 581.81 & 226.89 & 523.38 & 975.21 & 705.53 & 31.18 & 176.62 & 609.51 & 227.33 & 253.35 & 462.50 & 82.31 & 137.07 & 20.60 & 179.64 \\
\hline 11 & 592.07 & 219.78 & 576.96 & 956.19 & 752.44 & 29.88 & 155.99 & 603.46 & 247.95 & 270.99 & 488.69 & 76.11 & 136.55 & 21.62 & 182.15 \\
\hline 12 & 549.96 & 217.43 & 518.62 & 940.07 & 650.44 & 31.68 & 178.22 & 599.95 & 230.79 & 250.38 & 463.39 & 79.28 & 135.17 & 20.00 & 176.01 \\
\hline 13 & 107.75 & 42.04 & 115.44 & 186.97 & 142.79 & 6.87 & 31.98 & 104.05 & 44.86 & 48.41 & 90.28 & 15.58 & 26.45 & 4.89 & 35.42 \\
\hline 14 & 452.40 & 147.63 & 368.48 & 739.78 & 467.60 & 23.06 & 128.94 & 421.52 & 161.01 & 179.34 & 326.13 & 58.50 & 104.13 & 14.89 & 128.68 \\
\hline 15 & 69.59 & 34.46 & 69.84 & 128.27 & 71.28 & 3.49 & 19.23 & 79.24 & 38.38 & 42.73 & 75.60 & 9.95 & 18.19 & 2.58 & 24.03 \\
\hline 16 & 525.63 & 235.64 & 518.26 & 996.77 & 726.37 & 31.30 & 175.04 & 583.58 & 229.60 & 253.51 & 461.14 & 83.84 & 142.79 & 19.91 & 178.70 \\
\hline 17 & 569.72 & 231.45 & 574.80 & $1,033.32$ & 663.94 & 25.73 & 164.48 & 603.16 & 245.55 & 273.76 & 486.63 & 78.22 & 143.99 & 21.26 & 180.19 \\
\hline 18 & 356.15 & 116.21 & 388.09 & 610.46 & 505.48 & 22.76 & 128.92 & 427.50 & 169.07 & 186.52 & 335.95 & 50.58 & 85.75 & 12.99 & 120.63 \\
\hline 19 & 137.61 & 57.39 & 134.61 & 254.36 & 156.46 & 8.25 & 46.56 & 167.92 & 68.70 & 75.36 & 137.30 & 20.85 & 36.23 & 5.52 & 47.40 \\
\hline 20 & 570.96 & 232.38 & 584.75 & $1,048.13$ & 720.59 & 31.61 & 174.68 & 602.24 & 243.19 & 272.38 & 454.90 & 80.81 & 146.93 & 22.96 & 185.49 \\
\hline 21 & 515.41 & 215.55 & 524.31 & 978.27 & 700.82 & 31.34 & 177.81 & 614.44 & 233.73 & 258.93 & 465.00 & 77.41 & 136.80 & 20.72 & 177.35 \\
\hline 22 & 579.96 & 229.77 & 502.77 & $1,006.33$ & 736.17 & 31.60 & 176.92 & 619.38 & 246.50 & 274.83 & 486.41 & 76.38 & 140.05 & 21.75 & 183.02 \\
\hline 23 & 505.04 & 229.97 & 498.55 & 950.68 & 422.74 & 30.67 & 174.11 & 528.21 & 238.04 & 260.88 & 472.83 & 69.75 & 120.84 & 20.71 & 167.10 \\
\hline 24 & 188.60 & 84.75 & 119.19 & 120.46 & 234.25 & 6.91 & 65.62 & 124.77 & 91.25 & 100.45 & 180.66 & 28.11 & 49.11 & 8.15 & 57.13 \\
\hline
\end{tabular}


Table A.8: Energy Consumption of Motors in Sawmill 3 (Cont.)

\begin{tabular}{|c|c|c|c|c|c|c|c|c|c|c|c|c|c|c|c|}
\hline Shift & $\begin{array}{l}\text { Main } \\
\text { Saw }\end{array}$ & $\begin{array}{l}\text { Re- } \\
\text { saw }\end{array}$ & Edger & Trimmer & $\begin{array}{l}\text { Gang } \\
\text { Saw }\end{array}$ & Debarker & $\begin{array}{c}\text { Debarker } \\
\text { Hydraulic } \\
\text { Motor }\end{array}$ & Chipper & $\begin{array}{c}\text { Compressor } \\
1\end{array}$ & $\begin{array}{c}\text { Compressor } \\
2\end{array}$ & $\begin{array}{c}\text { Compressor } \\
\mathbf{3}\end{array}$ & $\begin{array}{l}\text { Log } \\
\text { Turner }\end{array}$ & \begin{tabular}{|c|} 
Log \\
Deck \\
Motor
\end{tabular} & $\begin{array}{l}\text { Line } \\
\text { Bar } \\
\text { Motor }\end{array}$ & $\begin{array}{l}\text { Other } \\
\text { Motors }\end{array}$ \\
\hline 25 & 295.66 & 138.29 & 16.08 & 4.97 & 361.75 & 3.98 & 110.58 & 158.80 & 147.17 & 159.46 & 290.58 & 38.57 & 67.31 & 11.08 & 73.83 \\
\hline 26 & 496.86 & 171.81 & 471.78 & 872.85 & 658.43 & 24.74 & 138.65 & 558.51 & 215.80 & 235.73 & 429.44 & 68.75 & 122.32 & 18.99 & 157.77 \\
\hline 27 & 70.24 & 35.44 & 86.00 & 140.12 & 124.39 & 5.12 & 25.27 & 74.49 & 32.34 & 38.00 & 67.15 & 12.04 & 19.72 & 3.89 & 26.98 \\
\hline 28 & 565.63 & 200.33 & 501.20 & 923.40 & 537.40 & 25.42 & 144.23 & 537.35 & 210.98 & 247.67 & 429.83 & 69.65 & 127.72 & 18.92 & 160.87 \\
\hline 29 & 527.85 & 201.68 & 536.76 & 990.06 & 238.54 & 30.49 & 171.42 & 614.78 & 243.39 & 268.76 & 475.90 & 77.77 & 142.74 & 20.50 & 169.80 \\
\hline
\end{tabular}


Table A.9: Energy Consumption of Main Saw and Carriage Motor for Different Widths in Sawmill 1

\begin{tabular}{|c|c|c|c|c|c|c|c|c|c|c|}
\hline Shift & $\begin{array}{c}\text { 4" Width } \\
(\mathrm{kWh})\end{array}$ & $\begin{array}{c}\text { 6" Width } \\
(\mathrm{kWh})\end{array}$ & $\begin{array}{c}\text { 8" Width } \\
(\mathrm{kWh})\end{array}$ & $\begin{array}{l}\text { 10" Width } \\
(\mathrm{kWh})\end{array}$ & $\begin{array}{c}\text { 12" Width } \\
\text { (kWh) }\end{array}$ & $\begin{array}{c}\text { 4" Width } \\
\text { (kWh) }\end{array}$ & $\begin{array}{l}\text { 6" Width } \\
\text { (kWh) }\end{array}$ & $\begin{array}{l}\text { 8" Width } \\
\text { (kWh) }\end{array}$ & $\begin{array}{l}\text { 10" Width } \\
(\mathrm{kWh})\end{array}$ & $\begin{array}{l}\text { 12" Width } \\
\text { (kWh) }\end{array}$ \\
\hline & \multicolumn{5}{|c|}{ Main Saw } & \multicolumn{5}{|c|}{ Carriage Motor } \\
\hline 1 & 289.65 & 228.07 & 191.58 & 157.37 & 141.40 & 120.39 & 94.79 & 79.63 & 65.41 & 58.77 \\
\hline 2 & 212.37 & 167.22 & 140.46 & 115.38 & 103.68 & 99.14 & 78.07 & 65.57 & 53.87 & 48.40 \\
\hline 3 & 466.09 & 367.00 & 308.28 & 253.23 & 227.54 & 219.53 & 172.86 & 145.20 & 119.27 & 107.17 \\
\hline 4 & 490.77 & 386.43 & 324.60 & 266.64 & 239.59 & 219.53 & 172.86 & 145.20 & 119.27 & 107.17 \\
\hline 5 & 197.98 & 155.89 & 130.94 & 107.56 & 96.65 & 84.98 & 66.91 & 56.21 & 46.17 & 41.49 \\
\hline 6 & 224.85 & 177.05 & 148.72 & 122.17 & 109.77 & 106.22 & 83.64 & 70.26 & 57.71 & 51.86 \\
\hline 7 & 140.45 & 110.59 & 92.89 & 76.31 & 68.56 & 56.65 & 44.61 & 37.47 & 30.78 & 27.66 \\
\hline 8 & 350.14 & 275.70 & 231.59 & 190.23 & 170.93 & 162.88 & 128.25 & 107.73 & 88.49 & 79.52 \\
\hline 9 & 492.25 & 387.60 & 325.58 & 267.44 & 240.31 & 219.53 & 172.86 & 145.20 & 119.27 & 107.17 \\
\hline 10 & 471.28 & 371.09 & 311.71 & 256.05 & 230.08 & 219.53 & 172.86 & 145.20 & 119.27 & 107.17 \\
\hline 11 & 490.04 & 385.85 & 324.12 & 266.24 & 239.23 & 219.53 & 172.86 & 145.20 & 119.27 & 107.17 \\
\hline 12 & 309.94 & 244.05 & 205.00 & 168.39 & 151.31 & 134.55 & 105.95 & 88.99 & 73.10 & 65.69 \\
\hline 13 & 106.83 & 84.11 & 70.66 & 58.04 & 52.15 & 56.65 & 44.61 & 37.47 & 30.78 & 27.66 \\
\hline 14 & 356.18 & 280.46 & 235.58 & 193.51 & 173.88 & 148.71 & 117.10 & 98.36 & 80.80 & 72.60 \\
\hline 15 & 144.67 & 113.91 & 95.69 & 78.60 & 70.63 & 70.82 & 55.76 & 46.84 & 38.48 & 34.57 \\
\hline 16 & 483.61 & 380.80 & 319.87 & 262.75 & 236.10 & 219.53 & 172.86 & 145.20 & 119.27 & 107.17 \\
\hline 17 & 490.75 & 386.42 & 324.59 & 266.63 & 239.58 & 219.53 & 172.86 & 145.20 & 119.27 & 107.17 \\
\hline 18 & 463.28 & 364.79 & 306.42 & 251.70 & 226.17 & 205.37 & 161.71 & 135.83 & 111.58 & 100.26 \\
\hline 19 & 27.49 & 21.64 & 18.18 & 14.94 & 13.42 & 14.16 & 11.15 & 9.37 & 7.70 & 6.91 \\
\hline 20 & 443.74 & 349.40 & 293.50 & 241.09 & 216.63 & 191.20 & 150.55 & 126.47 & 103.88 & 93.34 \\
\hline 21 & 123.06 & 96.90 & 81.39 & 66.86 & 60.08 & 49.57 & 39.03 & 32.79 & 26.93 & 24.20 \\
\hline 22 & 356.68 & 280.85 & 235.92 & 193.79 & 174.13 & 169.96 & 133.83 & 112.41 & 92.34 & 82.97 \\
\hline 23 & 421.96 & 332.25 & 279.09 & 229.25 & 206.00 & 191.20 & 150.55 & 126.47 & 103.88 & 93.34 \\
\hline
\end{tabular}


Table A.9: Energy Consumption of Main Saw and Carriage Motor for Different Widths in Sawmill 1 (Cont.)

\begin{tabular}{|c|c|c|c|c|c|c|c|c|c|c|}
\hline Shift & $\begin{array}{c}\text { 4" Width } \\
(\mathrm{kWh})\end{array}$ & $\begin{array}{c}\text { 6" Width } \\
(\mathrm{kWh})\end{array}$ & $\begin{array}{c}\text { 8" Width } \\
(\mathrm{kWh})\end{array}$ & $\begin{array}{l}\text { 10" Width } \\
(\mathrm{kWh})\end{array}$ & $\begin{array}{c}\text { 12" Width } \\
\text { (kWh) }\end{array}$ & $\begin{array}{c}\text { 4" Width } \\
\text { (kWh) }\end{array}$ & $\begin{array}{c}\text { 6" Width } \\
\text { (kWh) }\end{array}$ & $\begin{array}{c}\text { 8" Width } \\
(\text { kWh })\end{array}$ & $\begin{array}{c}\text { 10" Width } \\
(\mathrm{kWh})\end{array}$ & $\begin{array}{l}\text { 12" Width } \\
\text { (kWh) }\end{array}$ \\
\hline & \multicolumn{5}{|c|}{ Main Saw } & \multicolumn{5}{|c|}{ Carriage Motor } \\
\hline 24 & 47.81 & 37.65 & 31.62 & 25.98 & 23.34 & 28.33 & 22.30 & 18.74 & 15.39 & 13.83 \\
\hline 25 & 446.54 & 351.61 & 295.35 & 242.61 & 218.00 & 219.53 & 172.86 & 145.20 & 119.27 & 107.17 \\
\hline 26 & 265.49 & 209.04 & 175.60 & 144.24 & 129.61 & 113.31 & 89.22 & 74.94 & 61.56 & 55.31 \\
\hline 27 & 227.78 & 179.35 & 150.66 & 123.75 & 111.20 & 106.22 & 83.64 & 70.26 & 57.71 & 51.86 \\
\hline 28 & 389.96 & 307.06 & 257.93 & 211.87 & 190.38 & 191.20 & 150.55 & 126.47 & 103.88 & 93.34 \\
\hline 29 & 340.12 & 267.81 & 224.96 & 184.79 & 166.04 & 148.71 & 117.10 & 98.36 & 80.80 & 72.60 \\
\hline 30 & 182.87 & 143.99 & 120.95 & 99.35 & 89.27 & 70.82 & 55.76 & 46.84 & 38.48 & 34.57 \\
\hline 31 & 456.80 & 359.69 & 302.14 & 248.18 & 223.00 & 219.53 & 172.86 & 145.20 & 119.27 & 107.17 \\
\hline 32 & 62.03 & 48.84 & 41.03 & 33.70 & 30.28 & 21.24 & 16.73 & 14.05 & 11.54 & 10.37 \\
\hline 33 & 429.30 & 338.03 & 283.94 & 233.24 & 209.58 & 198.29 & 156.13 & 131.15 & 107.73 & 96.80 \\
\hline 34 & 86.80 & 68.35 & 57.41 & 47.16 & 42.38 & 56.65 & 44.61 & 37.47 & 30.78 & 27.66 \\
\hline 35 & 406.76 & 320.29 & 269.04 & 221.00 & 198.58 & 191.20 & 150.55 & 126.47 & 103.88 & 93.34 \\
\hline
\end{tabular}


Table A.10: Energy Consumption of Main Saw, Carriage Motor, and Resaw for Different Widths in Sawmill 2

\begin{tabular}{|c|c|c|c|c|c|c|c|c|c|c|}
\hline Shift & $\begin{array}{c}\text { 4" Width } \\
(\mathrm{kWh})\end{array}$ & $\begin{array}{l}\text { 6" Width } \\
(\mathrm{kWh})\end{array}$ & $\begin{array}{c}\text { 8" Width } \\
(\mathrm{kWh})\end{array}$ & $\begin{array}{c}\text { 10" Width } \\
(\mathrm{kWh})\end{array}$ & $\begin{array}{l}\text { 12" Width } \\
\text { (kWh) }\end{array}$ & $\begin{array}{l}\text { 4" Width } \\
(\mathrm{kWh})\end{array}$ & $\begin{array}{l}\text { 6" Width } \\
(\mathrm{kWh})\end{array}$ & $\begin{array}{c}\text { 8" Width } \\
(\mathrm{kWh})\end{array}$ & $\begin{array}{l}\text { 10" Width } \\
(\text { kWh })\end{array}$ & $\begin{array}{l}\text { 12" Width } \\
\text { (kWh) }\end{array}$ \\
\hline & \multicolumn{5}{|c|}{ Main Saw and Carriage Motor } & \multicolumn{5}{|c|}{ Resaw } \\
\hline 1 & 418.65 & 329.64 & 276.90 & 227.45 & 204.38 & 49.92 & 39.30 & 33.02 & 27.12 & 24.37 \\
\hline 2 & 52.19 & 41.09 & 34.52 & 28.35 & 25.48 & 8.47 & 6.67 & 5.60 & 4.60 & 4.14 \\
\hline 3 & 458.55 & 361.06 & 303.29 & 249.13 & 223.86 & 62.30 & 49.05 & 41.20 & 33.85 & 30.41 \\
\hline 4 & 484.96 & 381.86 & 320.76 & 263.48 & 236.75 & 63.58 & 50.06 & 42.05 & 34.54 & 31.04 \\
\hline 5 & 190.45 & 149.96 & 125.97 & 103.47 & 92.98 & 24.37 & 19.19 & 16.12 & 13.24 & 11.90 \\
\hline 6 & 302.67 & 238.33 & 200.19 & 164.45 & 147.76 & 39.75 & 31.30 & 26.29 & 21.60 & 19.41 \\
\hline 7 & 195.05 & 153.58 & 129.01 & 105.97 & 95.22 & 27.24 & 21.45 & 18.02 & 14.80 & 13.30 \\
\hline 8 & 281.56 & 221.70 & 186.23 & 152.97 & 137.45 & 37.72 & 29.70 & 24.95 & 20.49 & 18.41 \\
\hline 9 & 100.33 & 79.00 & 66.36 & 54.51 & 48.98 & 12.63 & 9.94 & 8.35 & 6.86 & 6.17 \\
\hline 10 & 378.69 & 298.18 & 250.47 & 205.75 & 184.87 & 47.35 & 37.28 & 31.32 & 25.73 & 23.12 \\
\hline 11 & 418.15 & 329.25 & 276.57 & 227.19 & 204.14 & 47.92 & 37.73 & 31.69 & 26.03 & 23.39 \\
\hline 12 & 472.78 & 372.27 & 312.71 & 256.87 & 230.81 & 64.73 & 50.97 & 42.81 & 35.17 & 31.60 \\
\hline 13 & 454.05 & 357.52 & 300.31 & 246.69 & 221.66 & 61.90 & 48.74 & 40.94 & 33.63 & 30.22 \\
\hline 14 & 435.64 & 343.02 & 288.14 & 236.69 & 212.67 & 55.82 & 43.95 & 36.92 & 30.33 & 27.25 \\
\hline 15 & 120.75 & 95.08 & 79.86 & 65.60 & 58.95 & 18.26 & 14.38 & 12.08 & 9.92 & 8.92 \\
\hline 16 & 211.42 & 166.47 & 139.83 & 114.86 & 103.21 & 25.93 & 20.41 & 17.15 & 14.09 & 12.66 \\
\hline 17 & 77.05 & 60.67 & 50.96 & 41.86 & 37.62 & 10.30 & 8.11 & 6.81 & 5.59 & 5.03 \\
\hline 18 & 496.65 & 391.06 & 328.49 & 269.83 & 242.46 & 52.93 & 41.68 & 35.01 & 28.76 & 25.84 \\
\hline 19 & 146.00 & 114.96 & 96.57 & 79.32 & 71.28 & 21.69 & 17.08 & 14.35 & 11.78 & 10.59 \\
\hline 20 & 297.94 & 234.60 & 197.06 & 161.87 & 145.45 & 40.65 & 32.00 & 26.88 & 22.08 & 19.84 \\
\hline 21 & 455.08 & 358.33 & 301.00 & 247.25 & 222.16 & 56.73 & 44.67 & 37.53 & 30.82 & 27.70 \\
\hline 22 & 456.58 & 359.51 & 301.99 & 248.06 & 222.90 & 64.39 & 50.70 & 42.59 & 34.99 & 31.44 \\
\hline
\end{tabular}


Table A.11: Energy Consumption of Main Saw, Carriage Motor, Resaw, and Gang Saw for Different Widths in Sawmill 3

\begin{tabular}{|c|c|c|c|c|c|c|c|c|c|c|}
\hline Shift & $\begin{array}{c}\text { 4" Width } \\
\text { (kWh) }\end{array}$ & $\begin{array}{l}\text { 6" Width } \\
\text { (kWh) }\end{array}$ & $\begin{array}{c}\text { 8" Width } \\
(\text { kWh })\end{array}$ & $\begin{array}{l}\text { 10" Width } \\
(\mathrm{kWh})\end{array}$ & $\begin{array}{c}\text { 12" Width } \\
(\mathrm{kWh})\end{array}$ & $\begin{array}{l}\text { 4" Width } \\
\text { (kWh) }\end{array}$ & $\begin{array}{l}\text { 6" Width } \\
\text { (kWh) }\end{array}$ & $\begin{array}{c}\text { 8" Width } \\
\text { (kWh) }\end{array}$ & $\begin{array}{c}\text { 10" Width } \\
(\mathrm{kWh})\end{array}$ & $\begin{array}{l}\text { 12" Width } \\
\text { (kWh) }\end{array}$ \\
\hline & \multicolumn{5}{|c|}{ Main Saw and Carriage Motor } & \multicolumn{5}{|c|}{ Resaw and Gang Saw } \\
\hline 1 & 606.78 & 477.78 & 401.33 & 329.67 & 296.2212 & 724.29 & 570.30 & 479.06 & 393.51 & 353.59 \\
\hline 2 & 692.91 & 545.60 & 458.31 & 376.47 & 338.2734 & 897.86 & 706.97 & 593.86 & 487.81 & 438.32 \\
\hline 3 & $1,222.81$ & 962.84 & 808.79 & 664.36 & 596.9613 & $1,473.34$ & $1,160.11$ & 974.49 & 800.47 & 719.27 \\
\hline 4 & 268.75 & 211.62 & 177.76 & 146.02 & 131.2031 & 368.09 & 289.84 & 243.46 & 199.99 & 179.70 \\
\hline 5 & $1,047.81$ & 825.05 & 693.04 & 569.28 & 511.5305 & $1,256.06$ & 989.02 & 830.78 & 682.43 & 613.19 \\
\hline 6 & $1,287.89$ & $1,014.08$ & 851.83 & 699.72 & 628.732 & $1,581.25$ & $1,245.08$ & $1,045.86$ & 859.10 & 771.95 \\
\hline 7 & $1,260.81$ & 992.76 & 833.92 & 685.01 & 615.5118 & $1,560.00$ & $1,228.34$ & $1,031.81$ & 847.56 & 761.57 \\
\hline 8 & $1,410.23$ & $1,110.42$ & 932.75 & 766.19 & 688.4578 & $1,741.66$ & $1,371.38$ & $1,151.96$ & 946.26 & 850.26 \\
\hline 9 & $1,313.09$ & $1,033.93$ & 868.50 & 713.41 & 641.0341 & $1,787.69$ & $1,407.63$ & $1,182.41$ & 971.27 & 872.73 \\
\hline 10 & $1,238.52$ & 975.21 & 819.18 & 672.90 & 604.6317 & $1,634.92$ & $1,287.34$ & $1,081.36$ & 888.26 & 798.15 \\
\hline 11 & $1,214.36$ & 956.19 & 803.20 & 659.77 & 592.8383 & $1,707.53$ & $1,344.51$ & $1,129.39$ & 927.71 & 833.60 \\
\hline 12 & $1,193.89$ & 940.07 & 789.66 & 648.65 & 582.8442 & $1,524.50$ & $1,200.39$ & $1,008.33$ & 828.27 & 744.24 \\
\hline 13 & 237.45 & 186.97 & 157.06 & 129.01 & 115.9217 & 318.18 & 250.54 & 210.45 & 172.87 & 155.33 \\
\hline 14 & 939.52 & 739.78 & 621.41 & 510.45 & 458.6609 & $1,168.40$ & 920.00 & 772.80 & 634.80 & 570.40 \\
\hline 15 & 162.90 & 128.27 & 107.75 & 88.51 & 79.52637 & 178.90 & 140.87 & 118.33 & 97.20 & 87.34 \\
\hline 16 & $1,265.90$ & 996.77 & 837.29 & 687.77 & 617.9966 & $1,590.03$ & $1,252.00$ & $1,051.68$ & 863.88 & 776.24 \\
\hline 17 & $1,312.32$ & $1,033.32$ & 867.99 & 712.99 & 640.6606 & $1,566.75$ & $1,233.66$ & $1,036.28$ & 851.23 & 764.87 \\
\hline 18 & 775.28 & 610.46 & 512.78 & 421.22 & 378.484 & $1,094.26$ & 861.62 & 723.76 & 594.52 & 534.21 \\
\hline 19 & 323.03 & 254.36 & 213.66 & 175.51 & 157.7007 & 373.46 & 294.06 & 247.01 & 202.90 & 182.32 \\
\hline 20 & $1,331.13$ & $1,048.13$ & 880.43 & 723.21 & 649.8421 & $1,640.27$ & $1,291.55$ & $1,084.90$ & 891.17 & 800.76 \\
\hline 21 & $1,242.40$ & 978.27 & 821.75 & 675.01 & 606.5276 & $1,544.61$ & $1,216.23$ & $1,021.63$ & 839.20 & 754.06 \\
\hline 22 & $1,278.03$ & $1,006.33$ & 845.31 & 694.37 & 623.9226 & $1,671.49$ & $1,316.13$ & $1,105.55$ & 908.13 & 816.00 \\
\hline 23 & $1,207.36$ & 950.68 & 798.57 & 655.97 & 589.4199 & $1,178.28$ & 927.78 & 779.34 & 640.17 & 575.23 \\
\hline
\end{tabular}


Table A.11: Energy Consumption of Main Saw, Carriage Motor, Resaw, and Gang Saw for Different Widths in Sawmill 3 (Cont.)

\begin{tabular}{|c|c|c|c|c|c|c|c|c|c|c|}
\hline Shift & $\begin{array}{c}4 " \text { Width } \\
(\mathrm{kWh})\end{array}$ & $\begin{array}{c}\text { 6" Width } \\
(\mathrm{kWh})\end{array}$ & $\begin{array}{c}\text { 8" Width } \\
(\mathrm{kWh})\end{array}$ & $\begin{array}{l}\text { 10" Width } \\
(\mathrm{kWh})\end{array}$ & $\begin{array}{c}\text { 12" Width } \\
\text { (kWh) }\end{array}$ & $\begin{array}{c}\text { 4" Width } \\
\text { (kWh) }\end{array}$ & $\begin{array}{l}\text { 6" Width } \\
(\mathrm{kWh})\end{array}$ & $\begin{array}{c}\text { 8" Width } \\
(\mathrm{kWh})\end{array}$ & $\begin{array}{c}\text { 10" Width } \\
(\mathrm{kWh})\end{array}$ & $\begin{array}{l}\text { 12" Width } \\
\text { (kWh) }\end{array}$ \\
\hline & \multicolumn{5}{|c|}{ Main Saw and Carriage Motor } & \multicolumn{5}{|c|}{ Resaw and Gang Saw } \\
\hline 24 & 152.98 & 120.46 & 101.19 & 83.12 & 74.68422 & 537.02 & 422.85 & 355.19 & 291.76 & 262.17 \\
\hline 25 & 609.50 & 479.92 & 403.13 & 331.14 & 297.5504 & 834.91 & 657.41 & 552.22 & 453.61 & 407.59 \\
\hline 26 & $1,108.52$ & 872.85 & 733.19 & 602.27 & 541.166 & $1,467.22$ & $1,155.29$ & 970.44 & 797.15 & 716.28 \\
\hline 27 & 177.95 & 140.12 & 117.70 & 96.68 & 86.87452 & 247.17 & 194.63 & 163.49 & 134.29 & 120.67 \\
\hline 28 & $1,172.72$ & 923.40 & 775.66 & 637.15 & 572.5075 & $1,400.86$ & $1,103.04$ & 926.55 & 761.09 & 683.88 \\
\hline 29 & $1,257.37$ & 990.06 & 831.65 & 683.14 & 613.8344 & 973.32 & 766.39 & 643.77 & 528.81 & 475.16 \\
\hline
\end{tabular}

